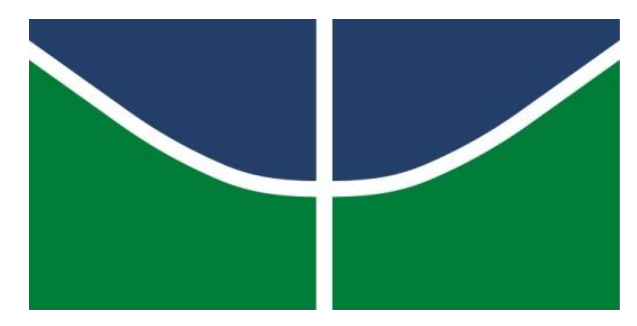

UNIVERSIDADE DE BRASÍLIA

INSTITUTO DE LETRAS

DEPARTAMENTO DE LÍNGUAS ESTRANGEIRAS E TRADUÇÃO

PROGRAMA DE PÓS-GRADUAÇÃO EM LINGUÍSTICA APLICADA

RENATA MOURÃo GUIMARÃES

PLANEJAMENTO CLIL POR TAREFAS: INTEGRANDO TEMAS E LÍNGUA PARA FINS ESPECÍFICOS NA EDUCAÇÃO PROFISSIONAL 


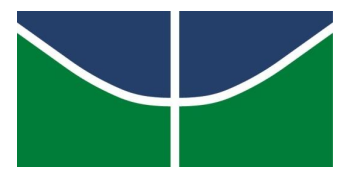

UNIVERSIDADE DE BRASÍLIA

INSTITUTO DE LETRAS

DEPARTAMENTO DE LÍNGUAS ESTRANGEIRAS E TRADUÇÃO

PROGRAMA DE PÓS-GRADUAÇÃO EM LINGUÍSTICA APLICADA

PLANEJAMENTO CLIL POR TAREFAS: INTEGRANDO TEMAS E LÍNGUA PARA FINS ESPECÍFICOS NA EDUCAÇÃO PROFISSIONAL

RENATA MOURÃO GUIMARÃES

ORIENTADORA: MAGALI BARÇANTE

Dissertação de Mestrado apresentada ao Programa de Pós-Graduação em Linguística Aplicada da Universidade de Brasília, como requisito parcial à obtenção do título de Mestre em Linguística Aplicada. 


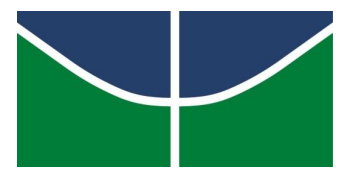

UNIVERSIDADE DE BRASÍLIA

INSTITUTO DE LETRAS

DEPARTAMENTO DE LÍNGUAS ESTRANGEIRAS E TRADUÇÃO

PROGRAMA DE PÓS-GRADUAÇÃO EM LINGUÍSTICA APLICADA

\title{
PLANEJAMENTO CLIL POR TAREFAS: INTEGRANDO TEMAS E LÍNGUA PARA FINS ESPECÍFICOS NA EDUCAÇÃO PROFISSIONAL
}

\author{
RENATA MOURÃO GUIMARÃES
}

Dissertação de Mestrado apresentada ao Programa de Pós-Graduação em Linguística Aplicada da Universidade de Brasília, como requisito parcial à obtenção do título de Mestre em Linguística Aplicada.

Aprovada por:

Prof. ${ }^{\text {a }}$ Dr ${ }^{\mathrm{a}}$. Magali Barçante

Faculdade de Tecnologia de Indaiatuba (FATEC) e Universidade de Brasília (UnB)

Orientadora

Prof. ${ }^{\mathrm{a}}$ Dra ${ }^{\mathrm{a}}$. Eliane Hércules Augusto-Navarro

Universidade Federal de São Carlos (UFSCar)

Examinadora Externa

Prof. Dr. José Carlos Paes de Almeida Filho

UnB

Examinador Interno

Prof. ${ }^{\text {a }}$ Dr ${ }^{\text {a. }}$ Vanessa Borges de Almeida

UnB

Examinadora Suplente

Brasília, 27 de agosto de 2015. 


\title{
REFERÊNCIA BIBLIOGRÁFICA E CATALOGAÇÃO
}

GUIMARÃES, Renata Mourão. Planejamento CLIL por tarefas: integrando temas e língua para fins específicos na educação profissional. Dissertação (Mestrado em Linguística Aplicada) - Departamento de Línguas Estrangeiras e Tradução, Universidade de Brasília, Brasília, 2015.

\begin{abstract}
Documento formal, autorizando reprodução desta dissertação de mestrado para empréstimo ou comercialização, exclusivamente para fins acadêmicos, foi passado pelo autor à Universidade de Brasília e acha-se arquivado na Secretaria do Programa. O autor reserva para si os outros direitos autorais de publicação. Nenhuma parte desta dissertação de mestrado pode ser reproduzida sem a autorização, por escrito, do autor. Citações são estimuladas, desde que citada a fonte.
\end{abstract}

FICHA CATALOGRÁFICA

Guimarães, Renata Mourão. Planejamento CLIL por tarefas: integrando temas e língua para fins específicos na educação profissional / Renata Mourão Guimarães; orientadora, Magali Barçante. - Brasília, DF, 2015. 220f.

Dissertação (Mestrado) - Universidade de Brasília, Departamento de Línguas Estrangeiras e Tradução, Programa de Pós-Graduação em Linguística Aplicada.

1. Espanhol para Fins Específicos. 2. Educação Profissional e Tecnológica 3. Planejamento de Curso. I. UNB. INSTITUTO DE LETRAS. II.TÍTULO.

CDU - 811.134.2:377 
À minha doce Beatriz. O significado de seu nome não poderia ser outro: a que traz felicidade. 
Logo, se quisermos ofertar cursos para atender as novas demandas do mercado, as novas exigências dos novos diferentes públicos de modo a fazer com que os alunos possam desempenhar-se eficientemente nas situações-alvo em que operam, deixo (...) uma pergunta para finalizar: é esta uma história com fim? Eu, particularmente, creio que esta é uma história que só pode ser construída para ser sempre inacabável (RAMOS, 2009, p.45). 


\section{AGRADECIMENTOS}

A Deus por guiar os meus passos e me propiciar persistência, determinação e tranquilidade durante a construção deste trabalho, e por colocar ao meu lado pessoas que contribuíram com meu desenvolvimento pessoal e profissional. De modo especial, agradeço:

- À minha pequena Beatriz, aos meus pais Adhemar e Teresinha e aos meus irmãos Luciane, Fernanda e Mateus. Pessoas de apoio e amor incondicional. Minha verdadeira fortaleza.

- À minha orientadora, professora Magali Barçante, pela confiança em meu trabalho, pela grande contribuição para minha prática como educadora e pesquisadora, pela paciência na orientação, por seu apoio e incentivo no amadurecimento de minhas ideias, além da indiscutível sensibilidade e compreensão. Um ser humano incrível que tive o prazer de conhecer.

- Ao professor José Calos Paes de Almeida Filho, o meu sincero agradecimento pelas valiosas discussões e contribuições para minha reflexão como docente, por participar da Banca de Qualificação e por novamente aceitar o convite para fazer parte da Banca Examinadora deste trabalho.

- À professora Vanessa Borges de Almeida, por participar da Banca de Qualificação e contribuir com orientações valiosas para o projeto e por novamente aceitar o convite para fazer parte da Banca Examinadora.

- À professora Eliane Hércules Augusto-Navarro, por aceitar o convite para fazer parte da Banca Examinadora.

- À professora Mariana Rosa Mastrella de Andrade, por me apresentar a Linguística Aplicada, à professora Maria Luisa Ortiz Alvarez, que foi tão importante na minha vida acadêmica, e ao professor Kleber Aparecido da Silva, que se dispôs a discutir o presente trabalho.

- Aos meus alunos, com os quais aprendo e por serem a razão de tudo isso, em especial aos desta pesquisa.

- Ao Cláudio, por ser o maior incentivador na superação de meus limites e por tudo o que representa para mim.

- A Vanessa, pela amizade, companheirismo e pela ajuda imensurável a este projeto.

- Âs colegas de trabalho e amigas Cláudia, Elisa, Jane e Sueli, que vivenciaram comigo o processo deste trabalho desde o meu ingresso no programa de pós-graduação até a conclusão desta dissertação. Pelos inúmeros momentos de nossas conversas em que pude expressar minhas angústias e ouvir palavras de incentivo e sugestões pertinentes para a construção deste trabalho.

- Às amigas irmãs de longa data, Aline e Roberta, por entenderem minha ausência.

- Às amigas, em especial, a Narciza, pela amizade que se construiu para além dos espaços da universidade e a Nélia, pelo incentivo, sugestões e apoio constante.

- Aos colegas do PPGLA, pelo convívio e pelas discussões enriquecedoras.

- Enfim, a todos que de alguma forma tornaram a realização deste trabalho possível. 


\section{RESUMO}

Este trabalho propõe identificar as implicações do planejamento CLIL/AICL (Aprendizagem Integrada de Conteúdos/Temas e Língua) por tarefas no processo de aprendizagem da língua espanhola em um curso técnico. O planejamento CLIL organiza o processo de ensinar, a partir de conteúdos do próprio currículo e temas de interesse e relevantes para os alunos, no intuito de se estimular a aprendizagem significativa com uso real da língua alvo, e utiliza, normalmente, as tarefas para a prática da língua. O planejamento CLIL por tarefas, no contexto pesquisado, fará parte de um replanejamento do componente curricular língua espanhola, ministrado atualmente em um curso técnico de nível médio de uma instituição de Educação Profissional e Tecnológica (EPT) da Rede Federal, configurando, assim, este estudo de natureza qualitativa-interpretativista como pesquisa-ação. Os dados para o replanejamento do componente curricular foram obtidos a partir da análise de objetivos (necessidades e interesses) dos alunos e das demandas do mundo do trabalho, materializadas nos documentos oficiais da EPT, e no mapeamento das situações de comunicação desenvolvidas por profissionais da área. Este trabalho tem seu aporte teórico fundamentado nos estudos sobre o ensino de línguas para fins específicos (ELFE), planejamento de cursos e ensino de línguas por conteúdos/temas e por tarefas. Os resultados apontam que o planejamento CLIL por tarefas tem o potencial de propiciar o desenvolvimento de competências para a formação profissional e cidadã na, para e pela língua(gem). Além disso, promove oportunidades para a aprendizagem significativa com trocas comunicativas relevantes para o agir direcionado a obter resultados e a obter entendimentos e acordos; promove motivação e expectativas futuras dos alunos para a aprendizagem da LE e de novas temáticas; maior participação do grupo com relatos de experiências (pessoais e profissionais) de forma voluntária; desenvolvimento da alteridade e tolerância à diversidade de opiniões; reconhecimento do aluno sobre suas próprias competências para trabalhar em equipe; aumento da corresponsabilidade no processo de ensinar e aprender; fomento à autoavaliação e autorreflexão dos alunos; percepção dos alunos quanto à multiplicidade de conhecimentos, atitudes e valores que possuem.

Palavras-chave: Educação Profissional e Tecnológica. Espanhol para Fins Específicos. Planejamento de Curso. 


\section{RESUMEN}

Este trabajo propone identificar las implicaciones de la planificación CLIL/AICLE (Aprendizaje Integrado de Contenidos y Lenguas Extranjeras) por tareas en el proceso de aprendizaje de la lengua española en un curso técnico. La planificación AICLE organiza el proceso de enseñanza, a partir de contenidos curriculares y temas de interés y relevantes para los alumnos, con el fin de estimular el aprendizaje significativo con uso reales de la lengua meta, y utiliza, normalmente, las tareas para la práctica de la lengua. La planificación AICLE por tareas, en este trabajo, será parte de un rediseño del componente curricular lengua española de un curso técnico de nivel medio de una institución de Educación Profesional y Tecnológica de la Red Federal, configurando, así, este estudio de naturaleza cualitativa-interpretativa como investigación-acción. Los datos para el rediseño del componente curricular fueron obtenidos por medio del procedimiento de análisis de objetivos (necesidades e intereses) de los alumnos y de las demandas del mundo del trabajo, materializadas en los documentos oficiales de la EPT y en el mapeo de las situaciones de comunicación desarrollada por profesionales del área. Este trabajo tiene su aporte teórico basado en estudios sobre la enseñanza de lenguas para fines específicos (ELFE), planificación de cursos y enseñanza-aprendizaje de lenguas por contenidos/temas y tareas. Los resultados muestran que la planificación AICLE por tareas tiene el potencial de propiciar el desarrollo de competencias para la formación profesional y ciudadana en el, para y por el lenguaje. Además, promueve oportunidades para un aprendizaje significativo con intercambios comunicativos pertinentes para el actuar dirigido a obtener resultados y a obtener entendimientos y acuerdos; promueve motivación y expectativas futuras de los alumnos para el aprendizaje de LE y de nuevas temáticas; mayor participación del grupo con informes de experiencias (personales y profesionales) voluntariamente; desarrollo de la alteridad y la tolerancia a la diversidad de opiniones; reconocimiento del estudiante sobre sus habilidades para trabajar en equipo; aumento de la corresponsabilidad en el proceso de enseñanza y aprendizaje; promoción de la autoevaluación y la autorreflexão de los estudiantes; percepción de los estudiantes cuanto a la multiplicidad de habilidades, actitudes y valores que poseen.

Palabras claves: Español para Fines Específicos. Educación Profesional y Tecnológica. Planificación de Curso. 


\section{LISTA DE FIGURAS}

Figura 1- Níveis e modalidades de ensino da Educação Profissional e Tecnológica ............... 21

Figura 2- Função curricular simultânea do CLIL ..................................................................29

Figura 3 - Modelos teóricos de competência comunicativa ................................................... 40

Figura 4 - Modelo de competência comunicativa, aprimorado em 2015 a partir do seu esboço

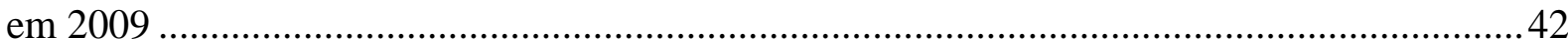

Figura 5 - Operação global de ensino de línguas (modelo OGEL) …..................................... 44

Figura 6- Roteiro para a elaboração de um planejamento de curso de línguas ........................47

Figura 7 - Ensino de línguas para fins específicos x Ensino de línguas para fins gerais ......... 49

Figura 8- Análise de objetivos: sua relação com recortes comunicativos e habilidades

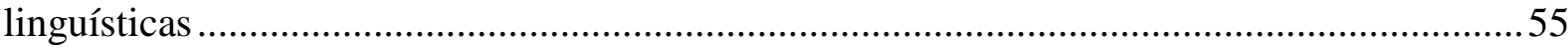

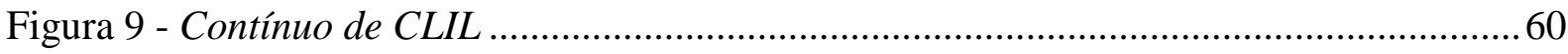

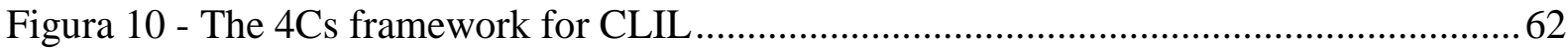

Figura 11 - Procedimento para a programação de unidades didáticas .................................... 71

Figura 12 - Mapa da taxonomia digital de Bloom.................................................................. 73

Figura 13- Cenário da expansão da EPT desde 2002 até 2014 ............................................ 83

Figura 14 - Tipos de planejamentos de caráter institucional e pedagógico............................ 122

Figura 15 - Habilidades integradas com destaque para a de maior ou menor proporção........125

Figura 16 - Habilidades integradas na Unidade 1 - destaque para a de maior ou menor

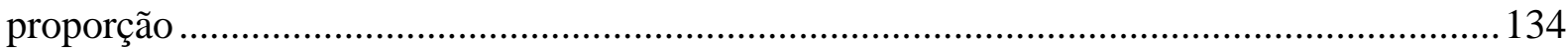

Figura 17 - Habilidades integradas na Unidade 2 - destaque para a de maior ou menor proporção.

Figura 18 - Habilidades integradas na Unidade 3 - destaque para a de maior ou menor proporção....

Figura 19 - Habilidades integradas na Unidade 4 - destaque para a de maior ou menor proporção

Figura 20- Fluxo da construção do planejamento de curso de LE na EPT 138

Figura 21- Estrutura da unidade tématica

Figura 22 - Triangulação dos instrumentos gerados na Parte I e Parte II 


\section{LISTA DE GRÁFICOS}

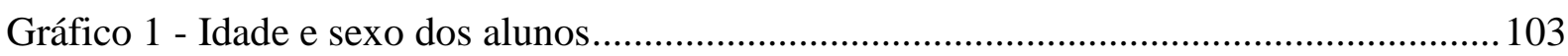

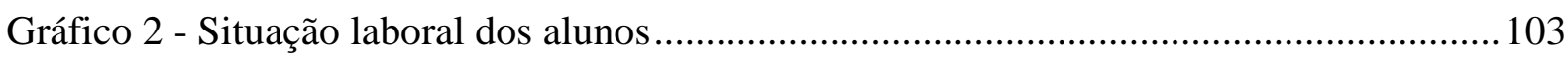

Gráfico 3 - Oportunidades conversacionais dos alunos no ambiente de trabalho .................. 104

Gráfico 4 - Fontes de informações mais acessadas pelos alunos ......................................... 105

Gráfico 5 - Assuntos que interessam aos alunos ............................................................... 105

Gráfico 6 - Formas de contato que os alunos tiveram com E/LE........................................ 108 


\section{LISTA DE QUADROS}

Quadro 1- Objetivos da EPT em alguns dos seus documentos legais...................................25

Quadro 2 - Características do planejamento CLIL por tarefas ............................................ 74

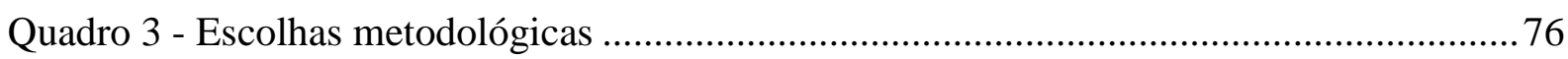

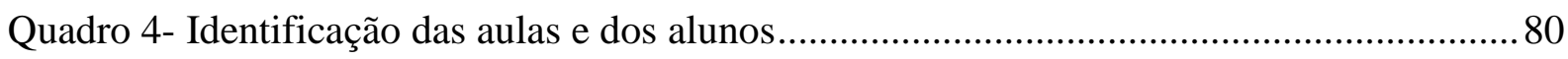

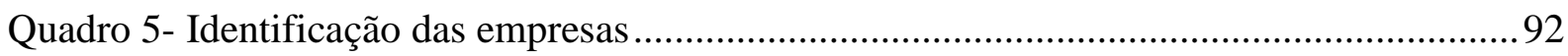

Quadro 6 - Evolução da Educação Profissional no Brasil ..................................................... 82

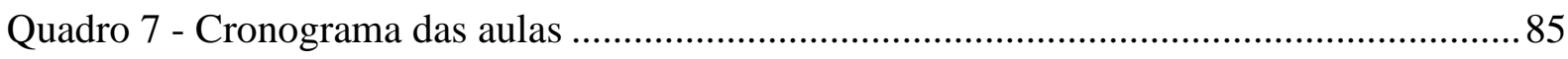

Quadro 8 - Objetivos da pesquisa e sua relação com instrumentos, participantes e

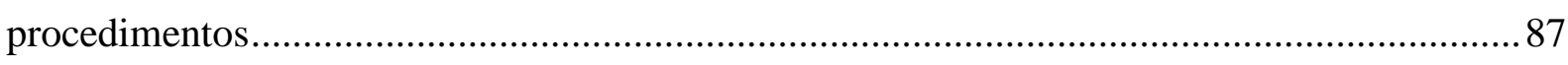

Quadro 9 - Princípios, critérios e competências da EPT técnica de nível médio para o

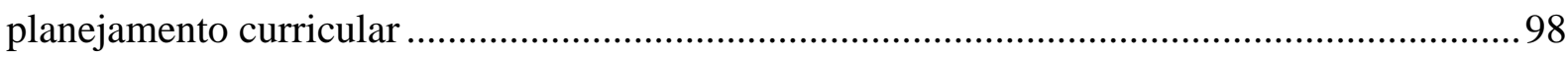

Quadro 10 - Relação da LE com níveis e modalidades de ensino............................................99

Quadro 11 - Critérios para o levantamento de objetivos dos alunos e necessidades da situaçãoalvo e da contemporaneidade do contexto pesquisado ......................................................... 100

Quadro 12 - Ocasiões e tempo de contato com o E/LE x quantidade de alunos .................... 107

Quadro 13 - Necessidades e interesses dos alunos do contexto pesquisado .......................... 110

Quadro 14 - Temas de interesse dos alunos do contexto pesquisado.................................... 112

Quadro 15 - Relação entre as 17 áreas do eixo Gestão e Negócios......................................... 113

Quadro 16 - Relação entre ação e finalidade ........................................................................ 116

Quadro 18 - Estrutura das unidades temáticas para este trabalho ....................................... 124

Quadro 19 - Configuração das unidades temáticas: temas, tópicos, objetivos....................... 131

Quadro 17- Relação entre os princípios de ELFE, EPT e CLIL .......................................... 140

Quadro 20 - Autoavaliação dos fatores individuais que contribuíram para a aprendizagem dos

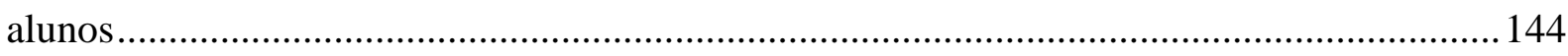

Quadro 21 - Autoavaliação das interações nas aulas............................................................. 149

Quadro 22 - Maiores ganhos dos alunos em termos de formação cidadã mencionados na autoavaliação 


\section{LISTA DE SIGLAS E ABREVIATURAS}

\begin{tabular}{|c|c|}
\hline AICL/CLIL & Aprendizagem Integrada de Conteúdos/Temas e Língua \\
\hline $\mathrm{CC}$ & Competência Comunicativa \\
\hline \multirow[t]{2}{*}{ DCNEP } & Diretrizes Curriculares Nacionais para a Educação Profissional de Nível \\
\hline & Técnico \\
\hline EFE & Espanhol para Fins Específicos \\
\hline E/LE & Espanhol como Língua Estrangeira \\
\hline ELFE & Ensino de Línguas para Fins Específicos \\
\hline EPT & Educação Profissional e Tecnológica \\
\hline IF & Instituto Federal de Educação, Ciência e Tecnologia \\
\hline $\mathbf{L E}$ & Língua Estrangeira \\
\hline LA & Linguística Aplicada \\
\hline L-alvo & Língua alvo \\
\hline LDB & Lei de Diretrizes e Bases da Educação \\
\hline LT & Língua(gem)/Trabalho \\
\hline MEC & Ministério da Educação \\
\hline MRCE & Marco Comum Europeu de Referência para as Línguas \\
\hline OGEL & Operação Global do Ensino de Línguas \\
\hline PCIC & Plano Curricular Instituto Cervantes \\
\hline PPP & Projeto Político Pedagógico \\
\hline TC & Tarefa Comunicativa \\
\hline $\mathbf{T F}$ & Tarefa Final \\
\hline TAL & Tarefa Possibilitadora \\
\hline TICs & Tecnologias da Informação e Comunicação \\
\hline ST & Sociedade/Trabalho \\
\hline UD & Unidade Didática \\
\hline UT & Unidade Temática \\
\hline
\end{tabular}




\section{SUMÁRIO}

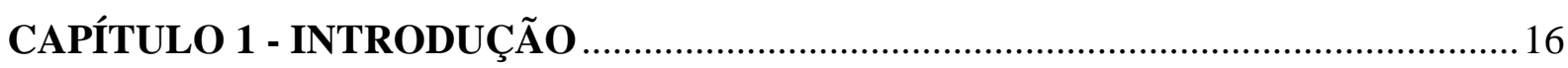

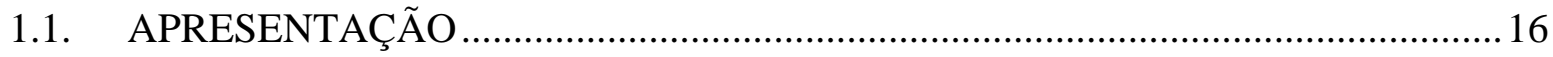

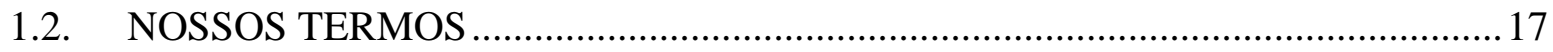

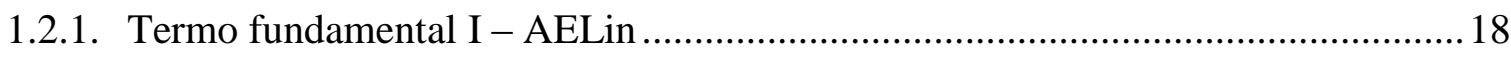

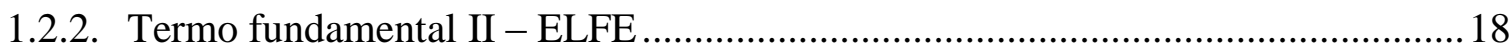

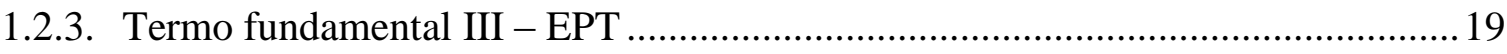

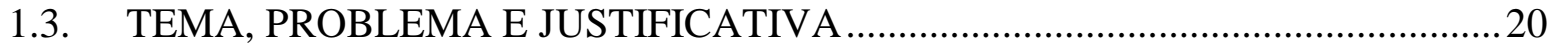

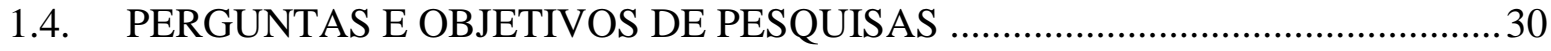

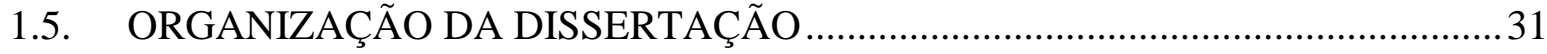

CAPÍTULO 2 - FUNDAMENTAÇÃO TEÓRICA …...................................................... 32

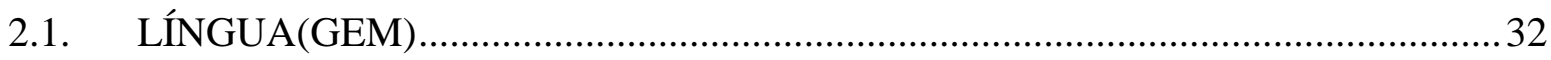

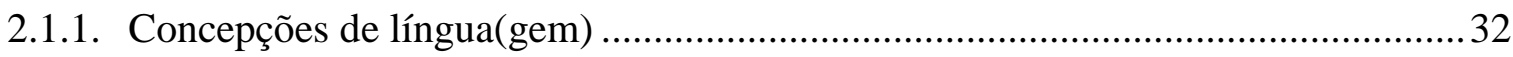

2.1.2. Relação entre a língua(gem) e o processo de aquisição/aprendizagem e ensino de

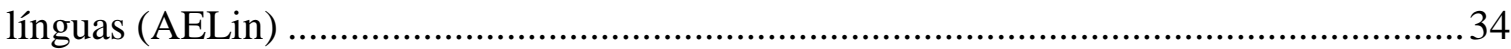

2.1.3. Língua(gem) e as abordagens de ensinar ......................................................... 36

2.1.4. Competência comunicativa e abordagem comunicativa ...................................... 38

2.1.5. Operação global de ensino de línguas (OGEL): o planejamento de curso............. 44

2.2. ENSINO DE LÍNGUA PARA FINS ESPECÍFICOS .........................................49

2.2.1. ELFE na Educação Profissional e Tecnológica ..................................................56

2.3. PLANEJAMETO CLIL (APRENDIZAGEM INTEGRADA DE CONTEÚDOS/TEMAS E LÍNGUA) POR TAREFAS ................................................ 60

2.3.1. Unidades temáticas no planejamento CLIL por tarefas ........................................ 70

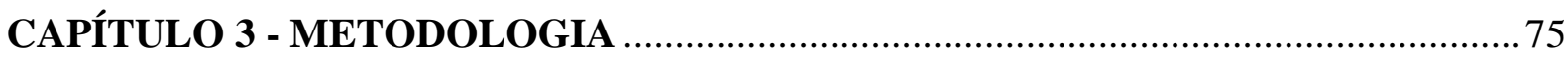

3.1. TIPO DE PESQUISA E POSIÇÃO EPISTEMOLÓGICA .................................... 76

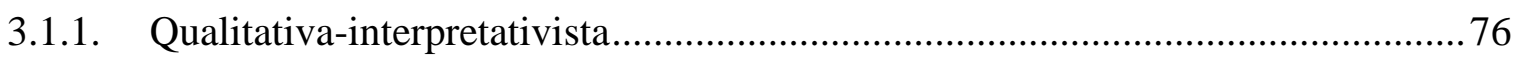

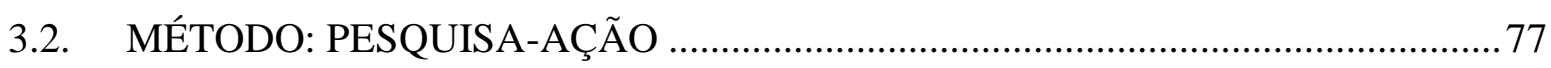

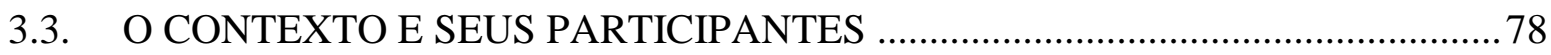

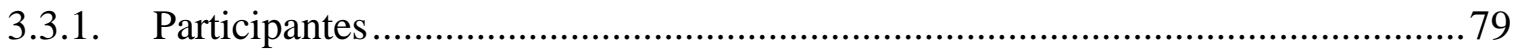

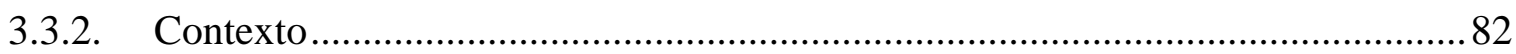




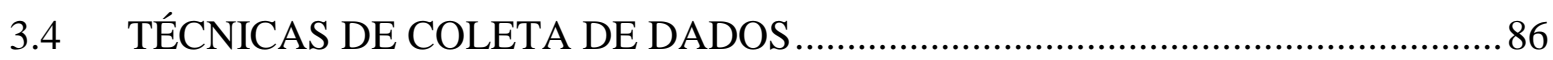

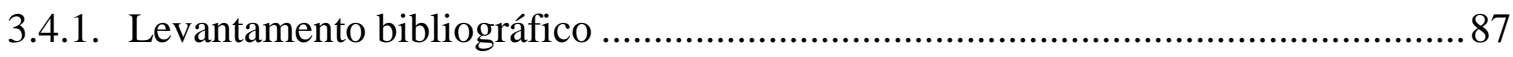

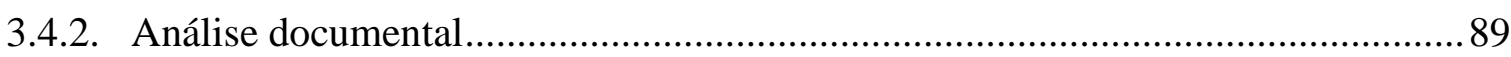

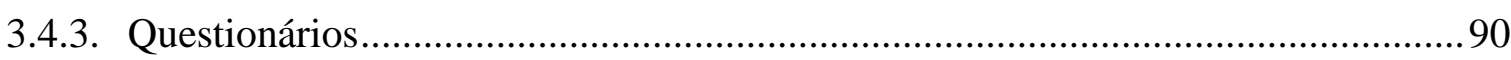

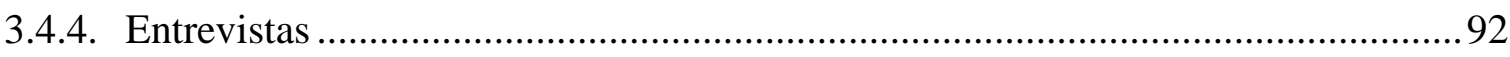

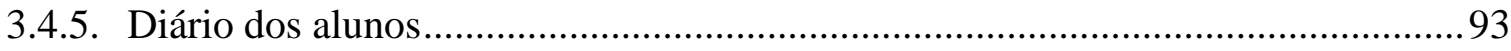

3.5 PROCEDIMENTOS PARA A ANÁLISE DOS DADOS ....................................93

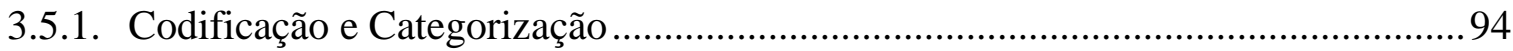

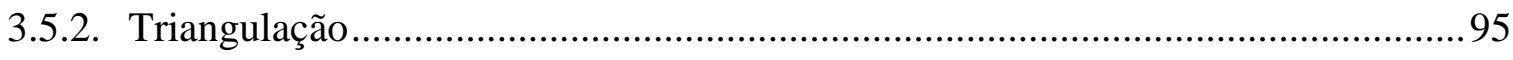

CAPÍTULO 4 - ANÁLISE E DISCUSSÃO DOS DADOS .............................................. 96

4.1 PARTE I - DA ANÁLISE DE OBJETIVOS AO PLANEJAMENTO DO CURSO ..... 98

4.1.1. Seção A: Elementos norteadores para a configuração do ELFE na EPT de nível

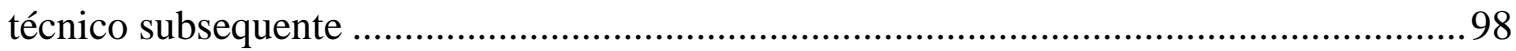

4.1.2.. Seção B: Informações coletadas a partir da análise de objetivos......................... 102

4.1.3. Seção C: Descrição do nosso planejamento CLIL por tarefas para o ELFE na EPT 121

4.2. PARTE II - DA IMPLEMENTAÇÃO À AVALIAÇÃO DO PLANEJAMENTO DO

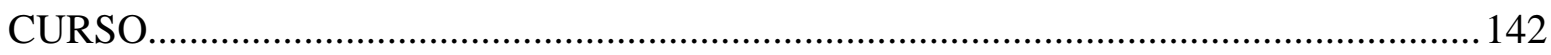

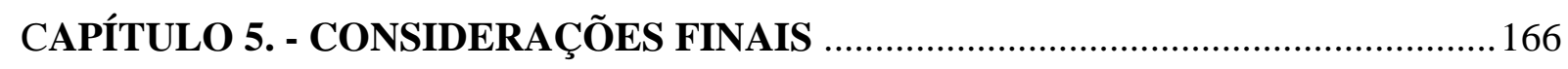

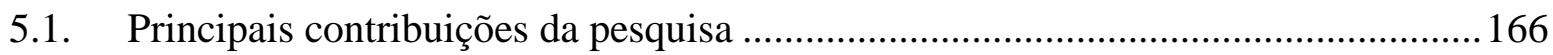

5.2. Limitações da pesquisa apontando propostas de trabalhos futuros ........................ 169

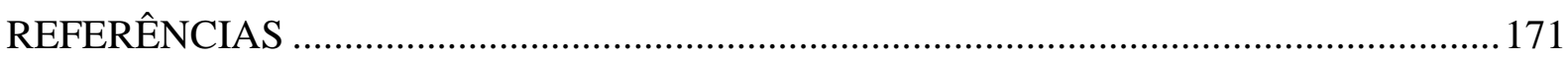

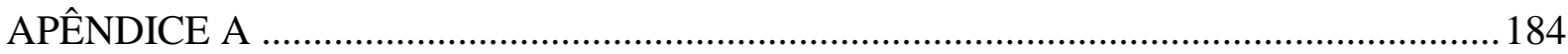

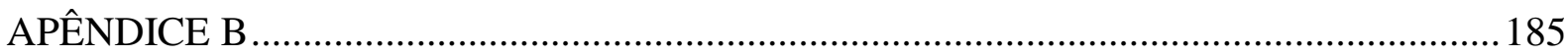

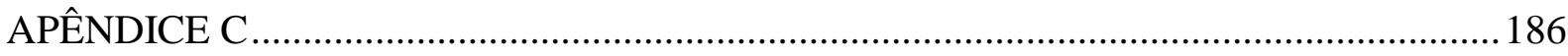

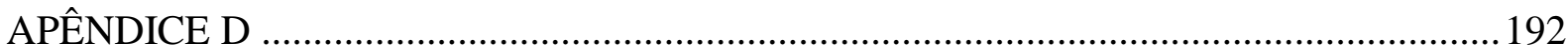

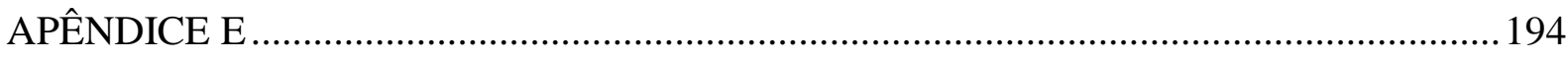

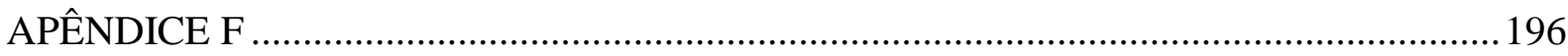

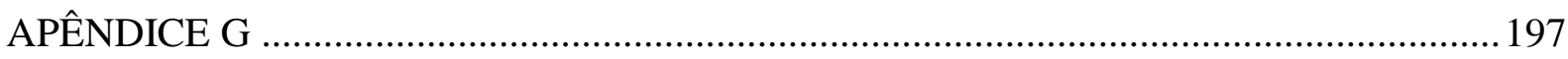

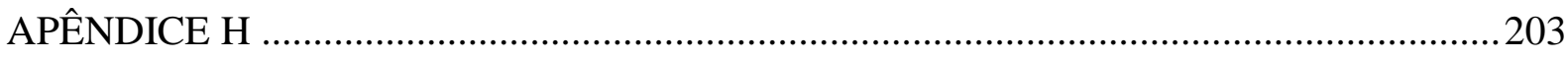

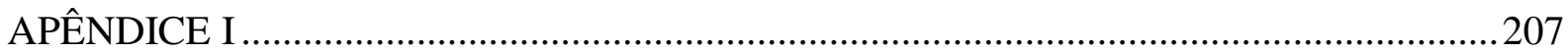




\section{CAPÍTULO 1 - INTRODUÇÃo}

O primeiro traço sobre um caderno em branco

\subsection{APRESENTAÇÃO}

O primeiro traço sobre um caderno em branco transforma-se em palavras que vão dando sentido a esse primeiro e a vários outros traços que ali foram surgindo. O primeiro traço foi feito em 2010, quando ingressei no Instituto Federal de Brasília (IFB) no cargo de docente de língua espanhola. Desde então, traços, esboços e palavras articuladas com um contexto (Educação Profissional e Tecnológica - EPT) e sujeitos (professor-pesquisador e alunos) produzem algumas tantas linhas de inquietações.

Como professora de espanhol em um curso técnico de nível médio subsequente - cursos destinados a alunos que já concluíram o Ensino Médio -, percebi que havia um distanciamento entre os conteúdos trabalhados nas aulas de espanhol como língua estrangeira (E/LE) e as necessidades que emergiam dos alunos, descritas por eles mesmos em conversas informais e coletadas por meio de questionários ${ }^{1}$ formulados a partir de uma competência implícita do professor (ALMEIDA FILHO, 1993, 2013).

Conforme a classificação de Almeida Filho (2013, p.34-35), as cinco competências do professor são: competência implícita, a mais básica, "constituída de intuições, crenças e experiências"; competência linguístico-comunicativa "para operar em situações de uso da Lalvo"; competência aplicada "que capacita o professor a ensinar de acordo com o que sabe conscientemente (subcompetência teórica) permitindo a ele explicar com plausibilidade porque ensina da maneira como ensina e porque obtém os resultados que obtém"; e competência profissional, "capaz de fazê-lo conhecer seus deveres, potencial e importância social no exercício do magistério na área de ensino de línguas".

\footnotetext{
${ }^{1} \mathrm{O}$ questionário inicial, aplicado aos alunos a partir de 2012, era composto por três perguntas abertas, a saber: qual o seu conhecimento em língua espanhola? O que você entende por espanhol instrumental? O que você espera aprender em espanhol durante este curso? A partir de 2013, passamos a acrescentar perguntas fechadas sobre tipos de interações (atividades, procedimentos e técnicas) que os alunos gostariam que fossem trabalhados em sala de aula e sobre suas necessidades de aprendizagem em uma relação direta com as habilidades linguísticas (ler, falar, ler e escrever). Já em 2014, iniciamos a reformulação desse questionário para o início desta pesquisa.
} 
Em 2011, como aluna especial ${ }^{2}$ do Programa de Pós-graduação em Linguística Aplicada da Universidade de Brasília (PPGLA), passei a compreender o que fazia implicitamente, dando contornos às demais competências do professor, descritas e analisadas por Almeida Filho (1993, 2009; 2011; 2012; 2013), Alvarenga (1999, 2004, 2009), Alvarenga e Bacellar (2007), Franco e Alvarenga (2005) e Barçante (2014). Hoje, um simples traço transformado em palavras, num texto infindável, vem completando algumas páginas desse caderno, agora já com alguns parágrafos construídos indutivamente nessa pesquisa(ação).

\subsection{NOSSOS TERMOS}

Esta seção não pretende ser um glossário, mas o esclarecimento sobre alguns vocábulos usados nesta dissertação, agrupados em termos fundamentais, por isso são apresentados em uma ordem didática e não alfabética.

Segundo Creswell (2010), esta seção, em um trabalho acadêmico, tem como objetivo definir os termos que os leitores podem necessitar para entender uma pesquisa, podendo ser colocada em diferentes partes do trabalho; no caso de nossa pesquisa optamos por colocá-la neste capítulo introdutório, uma vez que "a definição dos termos na introdução pode ajudar o leitor a entender o problema de pesquisa e as questões ou hipóteses do estudo" (CRESWELL, op. cit., p. 69).

Contudo, outros termos serão esclarecidos em notas de rodapé ao decorrer do trabalho, por não pertencerem a nenhuma ordenação temática específica das listadas a seguir; e outros termos aparecerão somente na seção de discussão e análise de dados (capítulo 4), tendo em vista, segundo Creswell (op.cit), que nos estudos qualitativos o projeto é indutivo e está em evolução, podendo alguns termos (perspectivas ou dimensões) emergir pela análise dos dados.

Os termos fundamentais e os vocábulos a eles relacionados são:

I - Aprendizagem/Aquisição e Ensino de Línguas (AELin);

II - Ensino de Línguas para Fins Específicos (ELFE);

III - Educação Profissional e Tecnológica (EPT).

\footnotetext{
2 A categoria "aluno não regular" ou "aluno especial" (como é mais comumente conhecida) constitui o que se denomina na literatura pedagógico-educacional de aluno exclusivamente vinculado a um ou mais componentes curriculares e não a um determinando curso (BRASIL, 2007, p. 3).
} 
Para o esclarecimento dos termos, foram utilizadas definições disponíveis na literatura e no Glossário de Linguística Aplicada (Glossa-LA) ${ }^{3}$.

\subsubsection{Termo Fundamental I - AELin}

Interação: troca linguageira construída entre falantes/escreventes e ouvintes/leitores de uma determinada língua ou línguas. Essa troca é basicamente comunicacional e, nela, estão inseridos, entre outros, os acessos à cultura produzida por ela e nela contida (GLOSSA-LA, 2015).

Troca propositada: é o tipo de interação promovido com os aprendentes de uma língua, que faz sentido por focalizar valores de verdade, parecidos com o que ocorre na vida real quando a língua é praticada para fins sociais comunicativos (GLOSSA-LA, 2015).

Ambiente comunicativo: atmosfera propícia à aquisição criada em atividades voltadas para a interação comunicativa, incrementando configurações favoráveis de filtro afetivo e a criação de abundante insumo do tipo que é compreensível enquanto desafia e que parece relevante e interessante ao aprendente (GLOSSA-LA, 2015).

Autonomia do aluno: sentimento consciente e capacidade do/a aluno/a de estar no controle do seu próprio aprendizado, sobre o qual ele(a) se posiciona no tempo e no espaço do ensino/aprendizagem de uma língua-alvo, com foco próprio no intuito aquisicional. $\mathrm{O}$ sentimento de autonomia resulta de motivação ou força interna individual e crescentemente mais consciente do aprendente de língua (GLOSSA-LA, 2015).

\subsubsection{Termo Fundamental II - ELFE}

Análise de objetivos: é o levantamento das necessidades e interesses dos alunos em relação à aprendizagem da LE e em relação ao curso. As necessidades fazem referência àquilo que o aluno precisa saber/produzir para que consiga se comunicar em um contexto ou em uma

\footnotetext{
${ }^{3}$ O Glossa-LA é um projeto de glossário online que abarca um repertório de palavras, expressões e siglas da Linguística Aplicada (LA), coordenado pelo professor-pesquisador Dr. José Carlos Paes de Almeida Filho do PPGLA/UnB, com a colaboração de alunos de graduação e pós-graduação. Atualmente, o Glossa-LA contém mais de 222 termos. Disponível em: <http://glossario.sala.org.br/>. Acesso em: 05 de agosto de 2015.
} 
determinada situação-alvo. Os interesses, por sua vez, são as expectativas do aprendiz em relação ao que gostaria de aprender.

Contexto: refere-se a realidades distintas. De maneira mais restrita, o termo faz referência unicamente às circunstâncias de espaço e tempo em que ocorre a comunicação, ou seja, o entorno físico imediato ou ainda o âmbito de uso: acadêmico, profissional, pessoal, público etc. (BELTRÁN, 2012).

Situação-alvo: refere-se a uma situação de uso da L-alvo que envolve o contexto em um âmbito maior, porém específico, calibrada pelos objetivos dos participantes. Ela pode ser determinada por diversas fontes (in loco, por documentos, pela literatura da área, por entrevistas e questionários, entre outros). É a partir da análise da situação-alvo que o syllabus de um curso de ELFE pode ser delimitado.

Syllabus: documento que indica o conteúdo do curso (HUTCHINSON e WATERS, 1987) - os temas, as habilidades, as funções comunicativas, os itens gramaticais e lexicais entre outros elementos que serão trabalhados.

\subsubsection{Termo Fundamental III - EPT}

Cursos Técnicos: voltados para o aluno que vai cursar ou já cursou o Ensino Médio e quer aprender uma profissão. Curso Tecnológico: É um curso superior, uma modalidade de graduação, assim como o bacharelado e a licenciatura (MEC, 20154).

Formação Integral Humana: adota o trabalho como princípio educativo, buscando a articulação ente teoria e prática, e negando a separação entre ensino propedêutico e ensino profissionalizante, geral e profissional, manual e intelectual. Seria, portanto, uma formação cidadã e profissional (politécnica) voltada para a cidadania plena e autônoma na qual elementos como trabalho, ciência, tecnologia e cultura são eixos estruturantes e indissociáveis (MOURA, 2008, 2010, 2012; FRIGOTTO, CIAVATTA e RAMOS, 2004, 2012).

\footnotetext{
${ }^{4}$ Respostas ao questionamento: qual a diferença entre curso técnico e curso tecnológico? Disponível em: http://portal.mec.gov.br/index.php?option=com_content\&view=article\&id=13063:qual-a-diferenca-entre-cursotecnico-e-curso-tecnologico \&catid=127\&Itemid=164 http://portal.mec.gov.br/index.php?option=com_content\&view=article\&id=13144:qual-a-diferenca-entre-cursostecnicos-e-tecnologicos\&catid=353\&Itemid=164. Acesso em: 05 de agosto de 2015.
} 
Politecnia: a noção de politecnia diz respeito ao domínio dos fundamentos científicos das diferentes técnicas que caracterizam o processo de trabalho produtivo moderno (...). Não se trata de um trabalhador que é adestrado para executar com perfeição determinada tarefa, e que se encaixe no mercado de trabalho para desenvolver aquele tipo de habilidade. Ele terá um desenvolvimento multilateral, que abarca todos os ângulos da prática produtiva moderna (SAVIANI, 1989).

Emancipação: significa o ato de tornar livre ou independente. O termo é utilizado em muitos contextos: emancipação do menor, emancipação da mulher, emancipação política, etc ${ }^{5}$. Já na área da educação, normalmente, o termo vem seguido da palavra humana ou do sujeito, demonstrando que o processo educativo deve proporcionar aos alunos "auto experiência, porque, nela, os processos de auto entendimento se entrecruzam com um ganho de autonomia" (TESSER, 2001).

\subsection{TEMA, PROBLEMA E JUSTIFICATIVA}

Relacionar, na prática, os objetivos da própria instituição, do mundo do trabalho, do componente curricular (no nosso caso da LE) com os objetivos dos alunos tem se tornado um desafio e anseio (do qual compartilhamos) entre os professores da área, uma vez que a educação profissional compreende uma série de processos educativos com natureza, duração e objetivos diferenciados para a capacitação, formação, e treinamento de jovens e adultos (CHRISTOPHE, 2005), em uma ampla variedade de cursos (em diferentes eixos tecnológicos ${ }^{6}$ ), em diferentes níveis e em modalidades variadas, conforme exposto no Decreto 5154/2004 (BRASIL, 2004) e ilustrado a seguir:

\footnotetext{
${ }^{5}$ http://www.significados.com.br/emancipacao/

${ }^{6}$ Ambiente e Saúde; Apoio escolar; Controle e Processos Industriais; Desenvolvimento Educacional e Social; Gestão e Negócios; Informação e Comunicação; Infraestrutura; Militar; Produção Alimentícia; Produção Cultural e Design; Produção Industrial; Recursos Naturais; Segurança e Turismo Hospitalidade e Lazer. Os eixos que se tem hoje na EPT são apresentados no Catálogo Nacional de Cursos Técnicos e Tecnológicos.
} 
Figura 1- Níveis e modalidades de ensino da Educação Profissional e Tecnológica

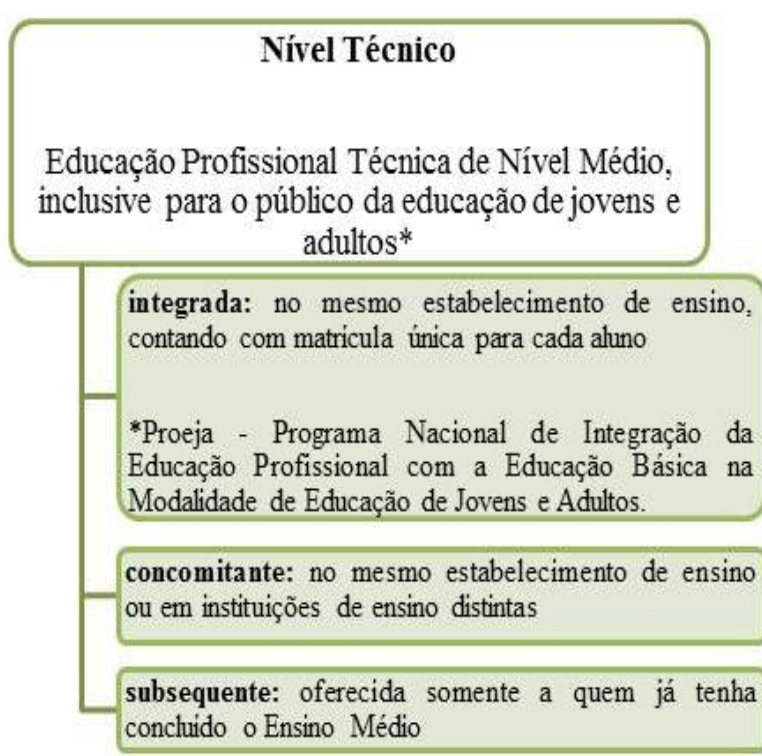
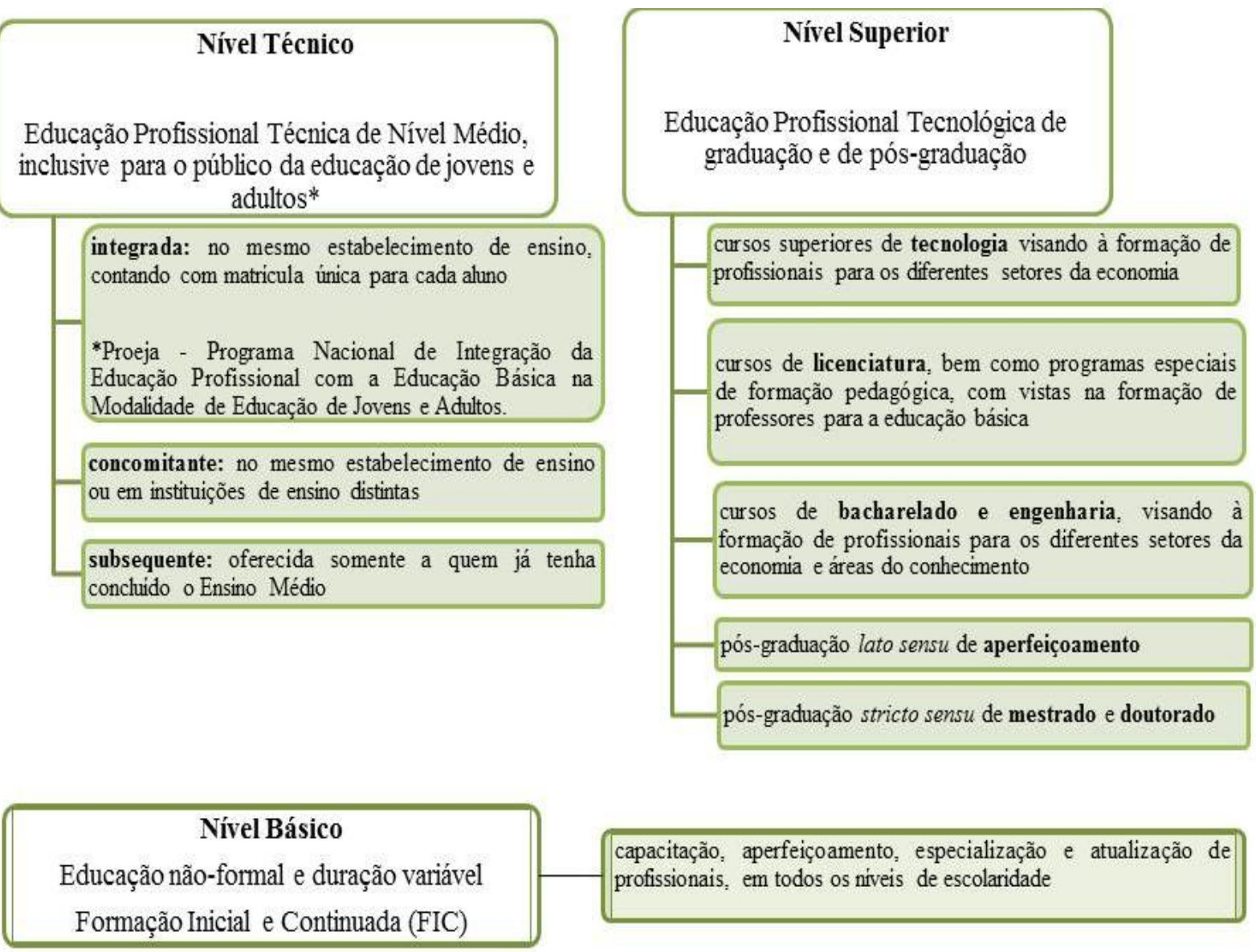

Fonte: Elaborado pela autora para tornar didática a informação

Considerando que os professores de línguas atuam em cursos de natureza e características distintas, em diferentes níveis e modalidades de ensino e nos mais diversos eixos tecnológicos no âmbito da instituição, passamos a questionar: qual tipo de ensino de LE poderia atender às especificidades e particularidades da EPT? Ou, ainda, como deve ser o ensino de LE em curso técnico de nível médio subsequente? (nível e modalidade objeto do nosso estudo).

O ensino de línguas na EPT possui um caráter muito específico, singular e particular e entendemos que refletir sobre esses pormenores, por meio de pesquisas com o levantamento de objetivos de aprendizagem de diferentes grupos, de diferentes áreas, amostras de materiais didáticos, syllabus, relatos de experiências, seja um percurso importante na tentativa de relacionar e amenizar os desencontros entre tais objetivos (dos alunos, da instituição formadora, do mercado de trabalho e da sociedade) na prática.

A motivação deste trabalho, que aborda a elaboração, implementação e avaliação de um planejamento de curso para o ensino de espanhol na EPT, emerge, portanto, do questionamento 
inicial sobre os desafios de atuação do docente de LE nesse contexto e a sua justificativa se dá a partir das seguintes perspectivas:

I. Necessidade de reflexão sobre o percurso metodológico do ensino da LE na EPT atualmente: ensino instrumental, para fins específicos, língua técnica (como é o ensino de LE na EPT?);

II. Necessidade de compreensão sobre qual deve ser o foco do ensino da LE na EPT segundo as especificidades e particularidades de cada nível e modalidade de ensino, eixo ou área (como deve ser o ensino de LE na EPT?);

III. Escassez de estudos e a necessidade de ampliar e motivar reflexões sobre o processo de ensinar línguas na EPT (como planejar cursos, elaborar materiais, viabilizar uma experiência de aprender a L-alvo, avaliar o aluno ${ }^{7}$ na EPT?).

\section{Necessidade de reflexão sobre o percurso metodológico para o ensino da LE na EPT atualmente: ensino instrumental, para fins específicos, língua técnica}

No Brasil, quando se trata de ensino de línguas em contexto universitário e/ou profissionalizante, como nas escolas da Rede Federal de EPT, o que inclui os Institutos Federais (IFs) - objeto do nosso estudo -, por exemplo, tem-se utilizado, normalmente, o termo "ensino instrumental", "abordagem instrumental" ou "língua técnica" para nomear o componente curricular LE, associando-o ao ensino de leitura e/ou estratégia de leitura.

Entretanto, o ensino instrumental é um tipo de ensino planejado para atender aos objetivos dos aprendizes podendo ser a leitura e interpretação de textos, servindo, também, para atender a outros objetivos de uso da L-alvo. Dessa forma, para evitar uma ideia distorcida de que instrumental é leitura, em nosso país, passou-se a usar na literatura da área o termo "Ensino de Línguas para Fins Específicos" (ELFE) e outros com o mesmo teor terminológico ${ }^{8}$ : ensino de línguas para/com propósitos/finalidades específicas, línguas para fins específicos (LinFE) entre outros. Termos já utilizados em outras línguas, como o inglês, ESP (English for Specific Purposes), por ter sido a língua inglesa a primeira língua estudada para fins específicos e, atualmente, LPS (Language for Specific Purposes) englobando qualquer L-alvo; e, em espanhol, "enseñanza de lenguas para fines especificos", "lengua(s)/lenguaje(s) para/con

\footnotetext{
${ }^{7}$ As quatro dimensões ou materialidades do processo de ensinar línguas são descritas por Almeida Filho (1993, 2012, 2013).

${ }^{8}$ Embora ELFE nos pareça ser o termo mais abrangente e ideal, utilizaremos, neste estudo, indistintamente os termos ELFE e instrumental.
} 
propósitos/finalidades específicas", “lenguas de especialidad/especializadas",, "lenguas especiales" entre outros.

Ensino Instrumental ou ELFE, como o próprio nome indica, se refere ao ensino de línguas (materna ou estrangeira) direcionado para o aluno lidar com a L-alvo em determinado contexto e/ou situação-alvo, segundo suas necessidades/interesses e/ou necessidades requisitadas pela sua atuação social (pessoal e profissional). Tal uso estende-se ao ensino de línguas em contextos educacionais de natureza específica, como as escolas da Rede Federal de EPT e também as instituições estaduais como as Etecs e as Fatecs ${ }^{10}$.

Ao falarmos de ensino e aprendizagem de línguas para fins específicos, passamos a nos referir a um universo com grande amplitude de contextos e de situações que exigem uma análise criteriosa e bem desenvolvida do recorte que se deseja (AUGUSTO-NAVARRO, 2008).

Beltrán (1998, 2004, 2012) argumenta que, por estarmos diante de classificações determinadas pela evolução e pela demanda do entorno, torna-se difícil determinar o número e os tipos de classes de fins específicos que existem. Para Pizollato (et al., 2008, p.2), estamos sempre "falando uma língua dentro de contextos (ou fins) específicos", sendo assim, o tipo de fim específico se torna "reflexo das condições histórico-sociais de vida do sujeito-falante" e questionam: "ESP, EAP, EVP, EOP, ESS, EST, EBE ${ }^{11} \ldots \mathrm{Ou}$ simplesmente Inglês Instrumental?".

Entendemos, portanto, que a variedade de finalidades específicas decorre da própria evolução das condições de tempo e espaço na sociedade, o que tem influenciado muitos pesquisadores a utilizar termos mais abrangentes que alcançam diversos tipos de fins específicos. Contudo, encontramos, na literatura, divisões convergentes que separam fins específicos, principalmente, em fins profissionais e em fins acadêmicos (HUTCHINSON e WATERS, 1987; ROBINSON, 1991; DUDLEY-EVANS e ST. JOHN, 1998), com pequenas variações terminológicas.

\footnotetext{
${ }^{9}$ As línguas especializadas ou linguagens de especialidade constituem recursos específicos linguísticos e não linguísticos a serviços do ELFE. São recursos usados para "cobrir necessidades específicas de comunicação formal e funcional solicitada em cada uma das profissões ou ofícios dos diversos âmbitos técnicos e científicos, à medida que estas se desenvolvem" (GOMÉZ DE ENTERRÍA, 1998, p. 30).

${ }_{10}$ Trata-se do Centro Estadual de Educação Tecnológica Paula Souza, um complexo de 218 Escolas Técnicas Estaduais (Etecs), que atendem aos alunos em Ensinos Técnico, Médio e Técnico Integrado ao Médio, incluindo modalidades semipresencial, Educação de Jovens e Adultos (EJA) e especialização técnica, e 63 Faculdades de Tecnologia (Fatecs), atendendo em média 283 mil alunos em mais de 300 municípios. Além da graduação, são oferecidos cursos de pós-graduação, atualização tecnológica e extensão Fonte: http://www.centropaulasouza.sp.gov.br.

${ }^{11}$ Fins específicos - ESP; fins acadêmicos - EAP; fins vocacionais - EVP; fins ocupacionais - EOP; para Ciências Sociais - ESS; para Ciência e Tecnológica - EST; para Negócios e Economia - EBE.
} 
Para esta dissertação, a análise do catálogo de cursos técnicos ${ }^{12}$ e a análise da legislação da EPT foram alguns dos instrumentos que nos ajudaram a fazer o recorte do nosso contexto: o ensino técnico de nível médio subsequente em Logística - eixo Gestão e Negócios. Para o nosso trabalho utilizamos, portanto, o termo ELFE; e por se tratar de um curso técnico do eixo de Gestão e Negócios, utilizamos as seguintes variações: fins profissionais; fins ocupacionais; formação para o trabalho e para Negócios como sinônimos.

\section{Necessidade de compreensão sobre qual deve ser o foco do ensino da LE na EPT, segundo as especificidades e particularidades de cada nível, modalidade de ensino, eixo ou área}

Quanto ao ensino de línguas para fins profissionais, formação para o trabalho (objeto do nosso estudo), concordamos com Beltrán (2012) quando afirma que o foco do ensino de LE para a formação profissional deve ser o de promover o desenvolvimento da competência comunicativa nos alunos.

O planejamento do processo de ensino e aprendizagem para a comunicação direcionando para o âmbito profissional deve ser centrado no estabelecimento das condições adequadas para que os estudantes adquiram e desenvolvam a competência comunicativa que requerem sua atividade, isto é, as capacidades, habilidades e técnicas de comunicação que tem que aplicar em um determinando contexto (p.27).

O objetivo de formação para fins profissionais, citado por Beltrán (op. cit.), vem ao encontro, também, dos objetivos de formação de uma resposta às necessidades contemporâneas individuais e coletivas: o desenvolvimento de uma competência de uso na L-alvo "que lhes sirva de base para circular socialmente nessa língua-alvo pretendida e para nela fazer coisas ou obter efeitos" (ALMEIDA FILHO, 2011, p.52). Segundo Guimarães, Barçante e Silva (2014), "circular socialmente" e "fazer coisas" na contemporaneidade implicam, principalmente, o acesso/produção de informações e de conhecimento.

Acessamos e nos relacionamos por meio da língua(gem) com as diversas fontes de informações presentes na sociedade em âmbito político, cultural, econômico, social, educacional, científico, cotidiano, entre outros e com o conhecimento produzido em diversas áreas. Para nos relacionarmos no mundo da comunicação precisamos também “de outra(s)

\footnotetext{
12 A versão 2012 do Catálogo Nacional de Cursos Técnicos contempla 220 cursos, distribuídos em 13 eixos tecnológicos, e constitui-se em referência e fonte de orientação para a oferta dos cursos técnicos no país. Nessa nova edição, foram incluídos novos 35 cursos e outros nove tiveram a nomenclatura alterada (BRASIL, 2012).
} 
língua(s) geradora(s) de conhecimento crucial para as nossas (novas) necessidades e possibilitadoras do acesso imediato a essa crucial produção fora da língua materna" (ALMEIDA FILHO, 2008, p. 1).

Além de favorecer e acelerar o acesso às informações e aos conhecimentos produzidos em meio impresso e/ou eletrônico, pela fala e/ou escrita, para muitos, saber uma LE tem se tornado um fator determinante para: uma boa colocação profissional, dado que o mercado de trabalho, geralmente, tem buscado selecionar candidatos "fluentes" em um idioma estrangeiro; ascensão educacional (ingresso em curso de graduação e pós-graduação stricto sensu); possibilidade de maior produtividade e visibilidade científica; intercâmbio científico e cultural $^{13}$; mobilidade (expatriação ${ }^{14}$, e (i)migração, a serviço da nação e/ou a serviço de organizações - embaixadas e consulados; serviço militar; programas de saúde, religiosos, educacionais); utilização de redes de informações, como a internet, por exemplo, propiciada pela competência comunicativa em diferentes línguas.

Interagir com pessoas de outras culturas e falantes de outra língua nos permite conhecer diferentes "modos de pensar e agir" (RAJAGOPALAN, 2003, p. 70), preparando-nos, conforme nos explica Richards (2006, p.38), para a nossa “sobrevivência no mundo real”. Nessa interação, vislumbramos, ao conhecermos o outro, possibilidades de novas leituras do mundo, o que cria oportunidades para o desenvolvimento e refinamento da nossa criticidade e alteridade.

Tais apontamentos coincidem com os fundamentos que norteiam a organização curricular da EPT, que trazem o debate do compromisso da educação para o desenvolvimento de nossa cidadania, conforme exposto em alguns dos seus documentos legais, resumidos no quadro a seguir como objetivos da EPT.

Quadro 1- Objetivos da EPT em alguns dos seus documentos legais.

\begin{tabular}{|c|c|}
\hline DOCUMENTOS & OBJETIVOS \\
\hline $\begin{array}{l}\text { Parecer CNE/CEB no } 16 / 99 \\
-\quad \text { Trata das Diretrizes } \\
\text { Curriculares Nacionais para } \\
\text { a Educação Profissional de } \\
\text { Nível Técnico }\end{array}$ & $\begin{array}{l}\text { Desenvolvimento das competências apoiadas em bases } \\
\text { científicas e tecnológicas e em atributos humanos, tais como } \\
\text { criatividade, autonomia intelectual, pensamento crítico, } \\
\text { iniciativa e capacidade para monitorar desempenhos. }\end{array}$ \\
\hline
\end{tabular}

\footnotetext{
${ }^{13}$ Como o programa "Ciências sem fronteiras", doutorado sanduíche, participação em eventos.

14 (1) Ação de mudar de pátria, seja voluntariamente, seja, como normalmente acontece, por obrigação. (2) Membros de organizações que vivem e trabalham em países nos quais não têm cidadania. Americano trabalhando no Brasil ou vice e versa. http://www.dicionarioinformal.com.br/expatria\%C3\%A7\%C3\%A3o/
} 


\begin{tabular}{|c|c|}
\hline $\begin{array}{lr}\text { Resolução } & \text { CNE/CEB } \\
\mathrm{n}^{\circ} .04 / 1999 & -\quad \text { Institui } \\
\text { Diretrizes } & \text { Curriculares } \\
\text { Nacionais para o Técnico de } \\
\text { Nível Médio }\end{array}$ & $\begin{array}{l}\text { A educação profissional, integrada às diferentes formas de } \\
\text { educação, ao trabalho, à ciência e à tecnologia, objetiva } \\
\text { garantir ao cidadão o direito ao permanente desenvolvimento } \\
\text { de aptidões para a vida produtiva e social (...) atendimento } \\
\text { às demandas dos cidadãos, do mercado de trabalho e da } \\
\text { sociedade. }\end{array}$ \\
\hline $\begin{array}{ll}\text { Documento } & \text { Base da } \\
\text { Educação } & \text { Profissional } \\
\text { Técnica de } & \text { Nível Médio } \\
\text { Integrada ao Ensino Médio } \\
\text { (2007) }\end{array}$ & $\begin{array}{l}\text { Contribuir para a formação integral dos estudantes; trabalho } \\
\text { como princípio educativo, no sentido de superar a dicotomia } \\
\text { trabalho manual/trabalho intelectual; formação de cidadãos } \\
\text { capazes de compreender a realidade social, econômica, } \\
\text { política, cultural e do mundo do trabalho. }\end{array}$ \\
\hline $\begin{array}{l}\text { Documento Base do Proeja } \\
\text { (2007) }\end{array}$ & $\begin{array}{l}\text { Formação integral dos sujeitos, como forma de } \\
\text { compreender e se compreender no mundo. (...) Questões } \\
\text { vinculadas ao exercício da cidadania, como o de preparar o } \\
\text { sujeito para fazer uma leitura crítica do mundo, construindo } \\
\text { a emancipação. Projeto coletivo de emancipação humana e } \\
\text { o trabalho como princípio educativo. }\end{array}$ \\
\hline
\end{tabular}

Fonte: Elaborado pela autora

Sendo a LE importante para o mundo de trabalho, para o acesso à informação, ciência, tecnologia e cultura, uma atenção especial deve ser dada a ela em cursos da educação profissional (GUIMARÃES e BARÇANTE, 2015). Nesta perspectiva, a formação pelas línguas deve atender também aos objetivos da formação cidadã e profissional, uma vez que é por meio das línguas que nos relacionamos com pessoas e culturas diferentes, acessamos diversas fontes de informações presentes na sociedade e conhecimento produzido em diversas áreas.

Sendo assim, consideramos que o papel da LE na EPT envolve duas perspectivas simultaneamente: desenvolvimento da competência de uso na L-alvo (competência comunicativa - CC) e formação cidadã e profissional dos alunos, uma vez que desenvolver no aluno uma competência de uso na L-alvo tem um papel importante para sua formação integral, pois "circular socialmente" e "fazer coisas" em outras línguas contribuem para a nossa participação social, para ampliação da nossa compreensão do mundo e para a construção da nossa cidadania. Conforme escreve Bezerra (2012), o pleno exercício da cidadania passa pela comunicação, compreensão entre os pares, o saber buscar informações, interpretá-las e argumentar.

Desta forma, o ensino de línguas na EPT passa a ter uma função social na medida em que permite a nossa compreensão do mundo, contribui para reflexão sobre o contexto em que vivemos e as melhores formas de participar e intervir nesse. 


\section{Escassez de estudos e a necessidade de ampliar e motivar reflexões sobre o processo de ensinar línguas na EPT}

O ensino de LE vem ganhando cada vez mais espaço na educação formal e se tornado uma prioridade em muitas instituições formadoras, principalmente as de cunho profissional. Em vista disso, o ELFE vem ganhado relevância em publicações e em eventos nacionais e internacionais ${ }^{15}$ da área.

Alguns desses importantes debates têm girado em torno da necessidade de desconstrução dos mitos (RAMOS, 2005) e de ideias errôneas (AUGUSTO-NAVARRO, 2008) que circundam esse tipo de ensino, principalmente, as ideias de que instrumental é sinônimo de leitura, de que um curso de ELFE deve ser dado em língua materna e com o foco em apenas uma das habilidades linguísticas (ler, escrever, falar e ouvir). Outros trabalhos têm buscado contribuir para o levantamento de objetivos de aprendizagem de um determinado grupo de alunos ou de uma determinada área, a fim de auxiliar a elaboração de cursos, a construção de materiais didáticos e novas práticas.

Mas, apesar desses estudos no Brasil, ainda é escasso o número de trabalhos no contexto da EPT - dissertações e teses - (apêndice A) e sua importância de estudo é ímpar, dado o caráter relativamente rápido do avanço da EPT em âmbito nacional e a dificuldade de articular características específicas de determinados componentes (no caso da LE) aos objetivos dos alunos e do contexto em que se ensina (GUIMARÃES e BARÇANTE, 2015), uma vez que os objetivos são dinâmicos e caminham com o contexto sócio-histórico-cultural, variam de situação para situação, de contexto para contexto e de pessoa para pessoa. É por isso que o tratamento dado ao ensino da LE na formação profissional deve ser considerado como um importante e premente objeto de estudo.

Nesse sentido, é importante, também, que a forma como planejamos os cursos, como escolhemos ou produzimos os materiais didáticos, como materializamos as técnicas e os procedimentos para vivenciar a L-alvo na sala de aula e ainda como avaliamos nossos alunos atendam e acompanhem seus objetivos e as necessidades contemporâneas.

Levando em consideração tais apontamentos, e, principalmente, a escassez de investigações que avaliam a efetividade de novas práticas do ensino de LE em cursos da EPT

\footnotetext{
${ }^{15}$ Em 2015, III Congresso Nacional de Línguas para Fins Específicos/XXV Seminário Nacional de Inglês Instrumental/XIII Seminário Nacional de Línguas Instrumentais. Edição especial da revista Reverte sobre o ELFE (2008) e I e II Congresso Brasileiro de Línguas Estrangeiras na Formação Tecnológica (www.fatecid.com.br, www.fatec.edu.br).
} 
em nosso país, este trabalho pretende contribuir para ampliar e motivar reflexões sobre o processo de ensino e aprendizagem nesse contexto.

Quanto ao processo de ensinar línguas, daremos ênfase ao planejamento do curso, umas das quatro dimensões da Operação Global de Ensino de Línguas (OGEL), elucidadas por Almeida Filho (2013, p. 29):

1. o planejamento das unidades de um curso;

2. a produção de materiais de ensino ou a seleção deles;

3. as experiências na, com e sobre a língua-alvo realizadas com os alunos, principalmente dentro, mas também fora da sala de aula;

4. a avaliação de rendimento dos alunos (mas também a própria autoavaliação do professor e avaliação dos alunos e/ou externa do trabalho do professor).

Para a nossa pesquisa sobre planejamento de curso na EPT, encontramos, em Almeida Filho (2008), as primeiras reflexões teóricas da nossa revisão de literatura. Em seu artigo Aprendizagem e ensino de línguas em contextos tecnológicos, o autor sugere que o processo de ensino e aprendizagem seja conduzido por meio de escolhas temáticas ou de conteúdos das disciplinas do próprio currículo, com humanização dos excessos de forma (p. 6). O autor ressalta, ainda, que os materiais para o ensino, nesse contexto, não precisam ser feitos sob medida, mas são "esqueletos a serem completados por professores e alunos em ajustes cruciais" a cada contexto de ensino.

O ensino de línguas em contextos tecnológicos pode perfeitamente buscar ser comunicacional, favorecendo a abertura estratégica para pensar enquanto se aprendem conteúdos relevantes e enquanto se expande a compreensão cultural geral e tecno. (...) Ela ainda permite fugir da limitação do só saber descrever fatos gramaticais da própria língua (p. 7).

Por esses motivos, decidimos pela realização de uma pesquisa-ação, visando à elaboração de um planejamento voltado para a aprendizagem da LE em um curso técnico, integrando conteúdos (do próprio currículo e temas do cotidiano) e língua, combinados com o uso de tarefas (ALMEIDA FILHO e BARBITATO, 2000; BARBIRATO, 1999, 2005, 2008; XAVIER, 1999; ESTAIRE e ZANÓN, 1990). Esse processo é chamado, neste trabalho, de planejamento CLIL (DO COYLE, 2006; VERDUGO, 2011, MARSH, 2000, MARSH, et.al, 2001; MEHISTO, et.al., 2008) por tarefas. 
Em inglês CLIL é a sigla para Content and Language Integrated Learning, em português "Aprendizagem Integrada de Conteúdos e Língua" (AICL), em espanhol “Aprendizaje Integrado de Contenidos y Lenguas Extranjeras" (AICLE). Por ter "Content”, tradução literal para o português como conteúdo e esse termo poder evocar o sentido de ensino conteudista, optamos por acrescentar a palavra “Temas", uma vez que Content, nessa proposta CLIL, refere-se tanto a conteúdos curriculares quanto a temas da vida cotidiana. Assim, os termos CLIL, AICL e AICLE serão utilizados como sinônimos neste trabalho e farão referência a um tipo de planejamento integrado com função curricular simultânea e conjunta, com duplo objetivo: ensino e aprendizagem da L-alvo por meio de conteúdo/temas e o ensino e aprendizagem de conteúdos/temas por meio da L-alvo.

Figura 2- Função curricular simultânea do CLIL

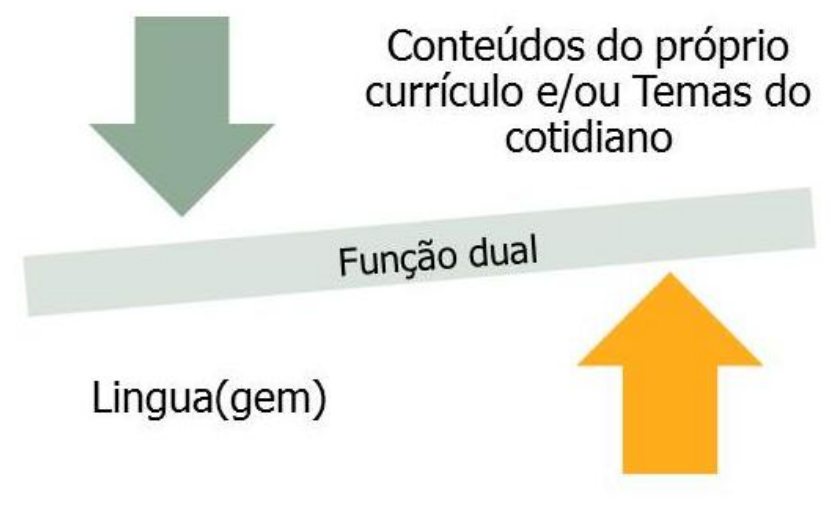

Fonte: Elaborado pela autora para tornar didática a informação

Para a elaboração dos temas e das tarefas ${ }^{16}$, nessa proposta de planejamento, nos baseamos, portanto, na análise de objetivos (necessidades e interesses) dos alunos; do contexto e da situação-alvo em que os alunos atuarão socialmente como um mecanismo para obter o compromisso; e envolvimento do aluno durante todo o processo de ensino e aprendizagem. Desse modo, será dada especial atenção as suas próprias percepções ${ }^{17}$ quanto ao seu desempenho durante o processo.

\footnotetext{
${ }^{16}$ Uma tarefa em sala de aula é uma atividade de prática da língua similar ao seu uso fora da sala de aula. As tarefas nessa pesquisa buscam atender ao contexto de comunicação autêntico aos utilizados na situação que os alunos atuarão profissionalmente e em situações comunicativas cotidianas. Elas são, portanto, recortes da prática social de uso da LE pelo aluno.

17 Nessa pesquisa, percepção está sendo utilizada com base no conceito dado por Chauí (1999). A percepção depende das coisas, do mundo e dos sentimentos, depende do exterior e do interior, num campo de significações visuais, olfativas, gustativas, sonoras, motriciais, temporais e linguísticas. A percepção é uma conduta vital, uma comunicação, interpretação e uma valoração do a partir da estrutura de relações entre corpo e mundo. Ela envolve
} 
Optamos, ainda, por buscar os efeitos do planejamento a partir da percepção dos próprios alunos para evitar o risco da subjetividade, apontado por Bogdan e Biklen (1994), quanto a possíveis atitudes do pesquisador que possam influenciar os dados.

Assim, este trabalho elabora, implementa e avalia a proposta elucidada, explicitada nas perguntas e nos objetivos de pesquisa a seguir.

\subsection{PERGUNTAS E OBJETIVOS DE PESQUISAS}

Propomos as seguintes questões norteadoras:

1. Que implicações o planejamento CLIL por tarefas para o ELFE na EPT pode ter para o desenvolvimento da competência comunicativa e formação integral dos alunos a partir de suas próprias percepções?

2. Como se configurou a construção de um planejamento CLIL por tarefas para o ELFE na educação profissional técnica de nível médio subsequente ${ }^{18}$ ?

Com base nas nossas perguntas norteadoras, esta pesquisa tem como objetivo geral:

Analisar as implicações do planejamento CLIL por tarefas para o desenvolvimento da competência comunicativa na L-alvo, e a formação integral dos alunos do contexto de Educação Profissional e Tecnológica (EPT) no componente curricular espanhol para fins específicos $(\mathrm{E} / \mathrm{FE})$.

E como objetivo específico, temos:

(i) Discutir procedimentos de elaboração de um planejamento CLIL por tarefas para o ELFE na EPT técnica de nível médio subsequente.

toda a personalidade do sujeito, sua história pessoal, afetividade, desejos e paixões, o mundo é percebido qualitativamente afetivamente e valorativamente para percepção.

${ }^{18}$ A Educação Profissional Técnica de Nível Médio é desenvolvida nas formas articulada e subsequente ao Ensino Médio: I - a articulada (integrada e concomitante). II - a subsequente, desenvolvida em cursos destinados exclusivamente a quem já tenha concluído o Ensino Médio. 


\subsection{ORGANIZAÇÃO DA DISSERTAÇÃO}

Esta dissertação está organizada em 5 capítulos, incluindo este capítulo introdutório no qual contextualizamos nosso objeto de estudo, apresentamos "nossos termos", o tema, o problema, a justificativa da pesquisa e também suas perguntas e seus objetivos de pesquisa.

No segundo capítulo, apresentamos as teorias que fundamentaram nosso trabalho. Levantamos conceitos, ideias comuns e divergentes sobre os temas pertinentes a esta dissertação, principalmente estudos teóricos e empíricos voltados para o processo de ensino e aprendizagem de línguas para fins específicos na educação profissional. Baseamo-nos na exploração de conceitos, paradigmas que pudessem trazer insumo para a estruturação de um planejamento de curso de ELFE no contexto elucidado (EPT). Tratamos da relação entre o construto língua(gem) e o processo de ensino e aprendizagem para fins específicos, mais especificamente o processo materializado em um planejamento de curso. Tendo em vista a ampla literatura disponível sobre os temas acima descritos, optamos por uma seleção que nos auxiliou a traçar um olhar teórico-metodológico para a elaboração de um planejamento CLIL por tarefas, nesse contexto.

O terceiro capítulo discorre sobre a natureza qualitativa-interpretativista de nossa pesquisa e as características de uma pesquisa-ação. Neste capítulo, também serão descritos o contexto no qual se insere o nosso trabalho, seus participantes, o cronograma do planejamento proposto, além dos instrumentos de coleta e análise de dados.

O quarto capítulo refere-se à análise dos dados, culminada em dois momentos, a saber: a) a fase exploratória e descritiva dos procedimentos de elaboração de um planejamento CLIL por tarefas para ELFE na EPT, a partir da discussão sobre as especificidades e as particularidades da formação profissional e da análise de objetivos dos alunos e da situaçãoalvo; e b) a interpretação e análise das implicações desse planejamento para a formação integral e para o desenvolvimento da CC na L-alvo dos alunos do contexto pesquisado, a partir de suas próprias percepções.

O quinto capítulo apresenta as considerações finais, trazendo as principais contribuições, limitações da pesquisa e apontamentos de propostas para trabalhos futuros. 


\section{CAPÍTULO 2 - FUNDAMENTAÇÃO TEÓRICA}

Palavras que vão dando sentido aos primeiros traços

\subsection{LÍNGUA(GEM)}

Diversos autores têm discutido a relação existente entre as concepções de língua(gem) e o processo de aquisição/aprendizagem ${ }^{19}$ e ensino de línguas (AELin), entre eles Almeida Filho (1993, 2012, 2013), Brown (2007), Larsen-Freeman (2003) e Richards e Rodgers (2001). As concepções de língua(gem) diferem e evoluem ao longo do tempo, isso explica, talvez, porque a forma como se ensinam línguas varia segundo o contexto histórico-social e sofre influência dos fundamentos epistemológicos que a sustentam e, consequentemente, das teorias sobre sua aquisição/aprendizagem. Por exemplo, "se tomarmos língua como ação social para a construção de relações e para a aprendizagem de conhecimentos, nossa ação vai ter de se pautar por essa concepção" (ALMEIDA FILHO, 2012, p. 11).

$\mathrm{Na}$ trajetória de construção epistemológica do construto língua(gem), diferentes concepções de língua foram concebidas a partir do próprio ensino e da própria aprendizagem. Isso explica ainda mais a estreita relação entre todos estes elementos: língua e linguagem/ensino/aprendizagem.

Dessa forma, consideramos necessário, primeiramente, trazer algumas dessas concepções com o objetivo de tentar compreender como elas influenciaram e influenciam as teorias de aquisição/aprendizagem de línguas e o processo de ensinar uma língua estrangeira, materializado nas ações (dimensões) da Operação Global de Ensino de Línguas (OGEL).

\subsubsection{Concepções de língua(gem)}

Algumas visões sobre o conceito de língua(gem) humana têm sido discutidas por linguistas aplicados e demais estudiosos da linguística e de outros campos da ciência.

Para Koch (2013), três visões têm sido mais frequentes no curso da história dos estudos linguísticos: linguagem como representação do mundo e do pensamento; como ferramenta de comunicação (um código) para a transmissão de informações (mensagens); e, como atividade, forma de ação, lugar de interação.

\footnotetext{
${ }^{19}$ Neste trabalho os termos aquisição e aprendizagem são usados indistintamente.
} 
Richards e Rodgers (2001) trazem, também, três concepções de linguagem: estrutural, funcional e interacional, ou seja, linguagem como sistema de elementos estruturalmente relacionados para codificar o significado; como veículo para a expressão do significado funcional; e, como ferramenta para a criação e a manutenção de relações sociais.

Resumindo as três concepções acima, a língua(gem) pode ser entendida como sistema de normas; como um conjunto de eventos comunicativos; e como espaço de interações em que a língua e os seus significados são obtidos em dependência de contextos históricos, sociais e culturais.

Dentre essas concepções apresentadas, o presente estudo está situado na concepção de linguagem como (inter)ação, enquanto atividade humana, prática social, e, para tanto, nos apoiamos em autores que tratam de aspectos como ação, interação e o uso social da língua(gem) (HABERMAS, 1989; 2012; KOCH, 2013; VYGOTSKY, 1998). Para Koch (2013, 2014), linguagem é uma atividade como qualquer outra atividade humana, portanto, uma ação.

\footnotetext{
Linguagem como atividade, como forma de ação, ação interindividual finalisticamente orientada; como lugar de interação que possibilita aos membros de uma sociedade a prática dos mais diversos tipos de atos, que vão exigir dos semelhantes reações e/ou comportamentos, levando ao estabelecimento de vínculos e compromissos anteriormente inexistentes $(\mathrm{KOCH}, 2013$, p. 8).
}

Segundo Vygotsky (1998), é a partir da relação (interação) com o outro por meio da linguagem que o homem se constitui em um ser sócio-histórico-cultural e constrói conhecimentos.

Para Habermas (2012, p. 590), “a linguagem é médium genuíno e insubstituível do entendimento". É um princípio possibilitador de acordos, consenso mútuo promovido pelas interações entre os indivíduos. O autor propõe a Teoria da Ação Comunicativa que se sustenta e se apoia na língua(gem) como uma forma de comunicação com vistas ao entendimento entre sujeitos de uma interação. Nessa perspectiva, a língua(gem) é um agir, que, segundo o autor, pode ser diferenciado em dois tipos no "agir social": um agir comunicativo (voltado ao entendimento, acordo existente ou a se negociar); e um agir estratégico/instrumental (voltado à obtenção de um fim desejado, orientado pelo êxito) que não concorrem entre si, mas se integram socialmente (p. 165-590).

É, portanto, a linguagem uma ação humana social/interacional constituidora e transformadora do conhecimento e das relações, uma vez que é por meio dela que podemos criar relações (interagir) com o mundo, com outras pessoas e com o "eu"; expressar e 
compartilhar ideias, valores, saberes, sentimentos, experiências; negociar acordos; e efetivar intenções por meio da fala/escrita, gestos, símbolos e sinais.

As teorias sobre o processo de adquirir/aprender línguas têm revelado implicações com as concepções de língua(gem) e essas, por sua vez, têm revelado influências sobre o processo de ensinar/educar línguas estrangeiras, temática que discutiremos nas seções que seguem.

\subsubsection{Relação entre a língua(gem) e o processo de aquisição/aprendizagem e ensino de línguas (AELin)}

Sobre as teorias de aquisição de línguas (ASL), Brown (2007) as separa em três grandes fases: Behaviorista/Estruturalista, Cognitivista e Construtivista/Interacionista, segundo alguns padrões históricos que se destacam na literatura sobre esses estudos.

Na primeira fase (Behaviorista/ Estruturalista - décadas de 1940 e 1950), os estudos de ASL baseavam-se na psicologia comportamentalista. A aquisição/aprendizagem da língua(gem) é resultado de estímulos e reforços, o que Skiner (1957) resume como “comportamento". Sendo assim, a aprendizagem de uma língua se dá por repetição, imitação, memorização, criação de hábitos, a partir de estímulos do ambiente.

Já na segunda fase (Cognitivista - década de 1960 a 1980), são ressaltados os estudos sobre cognição e estudos sobre análise de erro. Chomsky (1957) sugere que a capacidade para produzir e estruturar frases é inata ao ser humano. Neste sentido, o autor afirma que o ser humano possui um dispositivo no cérebro, responsável pela aquisição da língua(gem) (Dispositivo de Aquisição da Linguagem - DAL) e uma Gramática Universal (GU) que são ativados pelo insumo (input) que recebe.

Para Krashen ${ }^{20}$ (1977, 1985), o conhecimento de uma segunda língua ocorre de duas formas: conhecimento adquirido e aprendido. A aquisição requer uma comunicação natural, inconsciente. Por outro lado, a aprendizagem é consciente, significa o saber sobre a língua. A aprendizagem consciente funcionaria apenas como monitor, que consiste em uma ferramenta que edita, faz correções das produções orais e escritas. O sistema adquirido é responsável pela produção da língua, enquanto o sistema aprendido seria o responsável por monitorar essa produção. As pessoas adquirem língua(gem) somente se elas obtiverem insumo compreensível

\footnotetext{
${ }^{20}$ Para explicar este processo o pesquisador formulou cinco hipóteses: (1) Aquisição versus Aprendizagem; (2) Ordem Natural; (3) Input; (4) Monitor e (5) Filtro Afetivo.
} 
e se os seus filtros afetivos estiverem suficientemente baixos para permitir a entrada do insumo. Aprendizes poucos motivados, ansiosos e com baixa autoestima teriam um filtro afetivo alto, o que impediria a conexão do insumo com o DAL. Krashen prevê, ainda, que nós adquirimos as regras de uma língua em uma ordem natural independente da ordem como as regras são ensinadas em sala de aula.

A partir dos anos de 1970, surgem novas teorias nas áreas da linguística e da psicologia educacional, dando início à terceira fase (Construtivista/Interacionista). Essa visão considera os fatores sociais, comunicativos e culturais para a aquisição da língua(gem). Segundo esse ponto de vista teórico, a interação social e as trocas comunicativas entre as pessoas são prérequisitos básicos para a aquisição.

Larsen-Freeman (2003) fala a respeito da amplitude conceitual do tema língua(gem), de sua relação com o conteúdo didático a ser trabalhado e com as práticas de ensino. Para a autora, dependendo da nossa visão sobre língua(gem), privilegiamos certas teorias de AELin no processo de ensinar. Assim, as diferentes concepções de linguagem e as teorias de aquisição influenciam a construção dos métodos e das abordagens de ensinar presentes ao longo da história.

Não é incomum haver confusão conceitual e terminológica entre abordagem, método, metodologia e entre esses e técnicas e procedimentos usados em sala de aula. Anthony (1963), preocupado com a confusão terminológica entre os termos, apresenta, em seu artigo seminal, uma organização hierárquica das definições dos termos abordagem, método e técnica, no qual as técnicas (procedimentos ou atividades) executam um método, que é consistente com uma abordagem, esta definida como uma filosofia, que não se pode provar.

Almeida Filho (1993; 2013), tomando como base o modelo proposto por Anthony (1963), e ao definir abordagem como uma filosofia de trabalho do professor - neste caso, o trabalho de ensinar línguas, a qual traz consigo crenças, pressupostos, ideias, conceitos sobre o que é língua(gem), aprender e ensinar línguas - entende método como as oportunidades criadas para se experienciar a língua, ou a maneira de se ensinar; e metodologia como conjunto de ideias que justificam o ensinar de uma certa maneira.

Sendo assim, abordagem tem um sentido mais amplo, tratando dos pressupostos teóricos que cada professor tem acerca das concepções da natureza da língua(gem) e do processo de ensino e aprendizagem. A abordagem influencia a escolha das experiências diretas com e na língua-alvo (o método) e também a escolha das “outras dimensões do processo complexo (a operação) de ensinar uma língua, a saber, o planejamento curricular e/ou de programas específicos, os materiais de ensino, e a avaliação do próprio processo e dos seus agentes" 
(ALMEIDA FILHO, 2005, p. 63). Portanto, o método estaria abaixo da abordagem, compondo na mesma linha as quatro dimensões ou materialidades da OGEL.

\subsubsection{Língua(gem) e as Abordagens de ensinar}

A abordagem de ensinar está intimamente relacionada à concepção de língua(gem) e a sua manifestação na prática dos professores está sujeita a forças que atuam sobre ela (instituição, competências, material didático, cultura de aprender, colegas, para citar algumas), além de elementos das condições vigentes (tradição, história, políticas), resultando em uma abordagem predominante em sala de aula (ALMEIDA FILHO, 2013).

Almeida Filho (1993, 2013) discorre sobre duas abordagens: uma sustentada pelo foco na forma - abordagem gramatical (AG) - e outra com foco no sentido construído na interação - abordagem comunicativa (AC). Na AG, de acordo com Santos e Almeida Filho (2011), o conceito de LE aponta para uma estrangeirização da língua, ou seja, é língua dos outros sustentada pelo foco na forma (sistema de regras), na AC, por sua vez, a língua se desestrangeiriza ${ }^{21}$, deixa de ser a língua do outro e passa a ser a língua do aprendente.

A aprendizagem na AG é baseada no domínio das normas gramaticais, que permitirão a produção de sentenças corretas. Assim, ensinar LE é focar a forma, as técnicas como tradução de orações e itens lexicais, exercícios de transformação de sentenças, de repetições e substituições de palavras em detrimento do sentido. A AC, ao contrário, aponta a comunicação/interação na L-alvo como condição básica para a aquisição, utilizando-se de materiais autênticos, e técnicas como uso de trabalhos em pares e em grupos e os debates em sala de aula (SANTOS e ALMEIDA FILHO, op. cit.).

Os autores (op. cit.) explicam que há uma variação da AG, com características da AC, denominada Abordagem Gramatical Comunicativizada (AGc). Os professores que se enquadram nessa variante de AGc, mesclam evidentes preocupações com regras gramaticais, que precisam ser explicitadas e praticadas extensivamente no decorrer das aulas para, posteriormente, iniciar interações autênticas de uso da L-alvo com seus aprendizes, porém a base ainda é gramatical, com "características epidérmicas comunicacionais" (ALMEIDA FILHO, 2013, p. 8). Entendemos, porém, que não se trata de uma variação da AG, mas uma fase de transição inerente à mudança de paradigma, nesse caso, de abordagem, cujas

\footnotetext{
${ }^{21}$ A nova língua, para se desestrangeirizar, deve ser aprendida para e na comunicação, sem se restringir apenas ao domínio de suas formas e do seu funcionamento enquanto sistema (ALMEIDA FILHO, 1993, 2013).
} 
características da fase anterior não se apagam totalmente, outrossim, são ressignificadas (BLATYTA, 1999), em busca do que se coloca como novo e desejado, nesse caso, ensinar línguas “na comunicação e para a comunicação” (WIDDOWSON, 2005).

Pensar a língua(gem) em um ensino com foco no sentido e nos objetivos dos alunos e, consequentemente, no ensino de línguas em uma perspectiva comunicativa, hoje, já é bastante familiar para muitos docentes da nossa área, pois, desde a introdução de pressupostos da abordagem comunicativa, no final da década de 1970, existe uma preocupação de trazer, para a sala de aula, oportunidades de uso significativo e relevante da L-alvo pelos aprendizes e uma redefinição no papel do professor e do aluno. Percebe-se, com isso, que o foco agora está na interação entre os sujeitos, busca-se a autonomia do aluno, as atividades passaram a ser mais dinâmicas e mais centradas nos aprendizes, como acontece nas atividades em pares ou em pequenos grupos, com o objetivo de que os alunos atinjam uma competência comunicativa (CC) na L-alvo. O aluno passou a ser considerado sujeito e agente do processo de sua aprendizagem, o que significa, para Almeida Filho (1993), mais atenção no que é significativo para o aprendiz.

Passamos assim, a partir da década de 1970, do paradigma gramatical (língua como sistema), para um paradigma comunicativo (língua como uso), manifestado inicialmente "para a comunicação" (funcional ${ }^{22}$ ), ainda presente nas práticas pedagógicas atuais, em busca de refinamento da essência comunicativa, ensinar "para e na comunicação", entendida para e no “agir social”, pois a comunicação é o próprio agir - atividade essencialmente humana, segundo Koch $(2013,2014)$, podendo ser esse agir guiado para uma finalidade e/ou para acordos e entendimentos (HABERMAS, 2012).

Segundo Widdowson (2005, p. 195-196), para que ocorra a comunicação, é necessária uma estreita relação das "habilidades linguísticas e capacidades comunicativas (...) para interpretar discurso, quer seja a ênfase colocada na produção, quer na recepção" que seria, para o autor, obter, portanto, uma competência comunicativa, que trataremos com detalhes na próxima seção.

\footnotetext{
${ }^{22}$ Em 1972, Wilkins sistematiza uma nomenclatura de funções comunicativas que passa a ser chamada de método nocional-funcional, em que se propõe que a comunicação seja entendida como expressão de noções, de significados, os quais servirão a uma determinada situação comunicativa. Esta noção é ainda de base gramatical. No final da década de 1970, Widdowson $(1978,2005$, p. 9) propõe que a língua seja ensinada não só para a comunicação, mas na comunicação. O autor rejeita o pressuposto de que "a língua é automaticamente ensinada como comunicação através do simples expediente de se concentrar em noções ou funções ao invés de estruturas frasais". Para ele, as pessoas não se "comunicam melhor por meio de noções isoladas ou realizando funções isoladas". Para tanto, o autor procura distinguir entre ensinar forma (gramatical) - "citação de palavras e frases enquanto manifestações de um sistema linguístico" - e uso (comunicativo) - "maneira pela qual o sistema se materializa com a finalidade de comunicação" (WIDDOWSON, 2005, p. 36).
} 


\subsubsection{Competência Comunicativa e Abordagem Comunicativa}

A competência comunicativa (CC) é, para Savignon (2002), a capacidade (habilidade) de aprendizes de uma língua interagirem com outros falantes e fazerem uso significativo da língua(gem). Seu desenvolvimento requer interação real entre os aprendizes, com o seu uso significativo e contextualizado; é, portanto, a CC "um processo contínuo de interpretar, expressar e negociar significados" (SAVIGNON, 1983, p. 8).

Para Almeida Filho (online) $)^{23}$, a CC é a "capacidade de mobilizar e articular conhecimento de língua e de comunicação, sob certas atitudes, em interação, com o propósito de se situar socialmente numa língua”. Desse modo, entendemos que o autor, ao falar de competência "em comunicação" se refere ao sentido mais estrito do conceito de competência que é a "faculdade de mobilizar saberes, capacidades, informações para solucionar uma série de situações" (PERRENOUD, 1999, p. 30) e atitudes, valores, crenças, etc. (BERGER, 1998) para e no uso da língua(gem). Segundo o $\mathrm{MCER}^{24}$, as competências podem ser divididas em quatro tipos, a saber:
a) Conhecimento declarativo - saberes;
b) Habilidades - saber fazer;
c) Competência existencial - saber ser;
d) Competência de aprender - saber aprender.

Os saberes dos alunos são os conhecimentos de mundo adquiridos por meio da experiência ou de fonte de informações a que teve acesso e engloba também conhecimento sociocultural. As habilidades (saber-fazer) estão dentro das competências (BERGER, op. cit.) e são as ações que envolvem a capacidade de atuação social (cotidiana, profissional e lazer etc.) por meio de atitudes. As competências existenciais são caracterizadas pelas atitudes, valores, motivações, estilos, tipo de personalidade dos alunos e a competência de aprender caracterizada pela capacidade de observar e participar de novas experiências e de incorporar novos conhecimentos aos prévios, modificando-os quando necessário (MCER, 2002).

As competências estão conectadas em uma única rede com os valores e saberes e ao serem estimuladas geram habilidades (BERGER, 1998). Para tanto, ter competência é

\footnotetext{
${ }^{23}$ http://let.unb.br/site-cc/home.html.

${ }^{24} \mathrm{http}: / / \mathrm{cvc}$. cervantes.es/ensenanza/biblioteca_ele/marco/indice.htm.
} 
reorganizar, reinterpretar, ressignificar tudo que aprendemos, lemos, escutamos e pensamos. Reorganizamos nossas competências por meio de nossas ações diárias, expondo (oralmente, por escrito, etc.) nossos conhecimentos, valores e atitudes ${ }^{25}$.

Essas ações (habilidades) em um planejamento de LE, por vezes são associadas às habilidades linguísticas (ler, escrever, ouvir e falar ${ }^{26}$ ). Entretanto, elas devem ser desenvolvidas em sala de aula de forma integrada, porque, na vida real, as atividades que realizamos em sala de aula, e mesmo fora dela, poucas vezes se restringirão a uma única das quatro habilidades, como "falar" (ALMEIDA FILHO, 1989, p. 63).

Portanto, ter uma competência comunicativa é desenvolver o uso da língua(gem) na e para a comunicação, o que requer não somente um saber (conhecimento de língua), mas saberfazer em contextos sociais (ações integradas) por meio de atitudes e da mobilização de valores.

O termo CC foi cunhado por Hymes $(1967,1972)$ e passa a incluir, além da competência linguística (domínio do sistema abstrato da língua-alvo da visão chomskiana), a capacidade de uso com o domínio das regras socioculturais da língua e do discurso (competência sociocultural). A partir de Hymes, outros pesquisadores passaram a construir modelos teóricos de $\mathrm{CC}$ e a incluir outras competências ao modelo inicial (como a competência estratégica, discursiva, textual, interacional, entre outras).

Apresentamos, a seguir (figura 3), os arcabouços teóricos dos modelos de CC no Brasil e no mundo. Podemos perceber que as competências iniciais de Hymes (linguística e sociolinguística), bem como a estratégica de Canale e Swain (1980) e a discursiva de Canale (1983), passam a compor uma estrutura básica de CC, com pequenas variações entre os arcabouços, e outras específicas de cada modelo teórico.

\footnotetext{
${ }^{25}$ ALVAREZ, Maria Luisa Ortiz - Notas de Aula da Disciplina Competência Comunicativa do Programa de Pós Graduação em Linguística Aplicada da Unidade de Brasília. Brasília: Universidade de Brasília - 06/11/2012 ${ }^{26}$ A prática de habilidades originária do método científico ou método direto (CHAGAS, 1978; MARTINEZ, 2009) se inicia com a apresentação de vocabulário numa frase (com um ensino puramente fonético) com pretensão de formar um núcleo vocabular, primeiramente para a leitura e para manter os alunos interessados em composições orais ou escritas, e conversação convencional (CHAGAS, 1978, p. 117-118).
} 
Figura 3 - Modelos teóricos de competência comunicativa

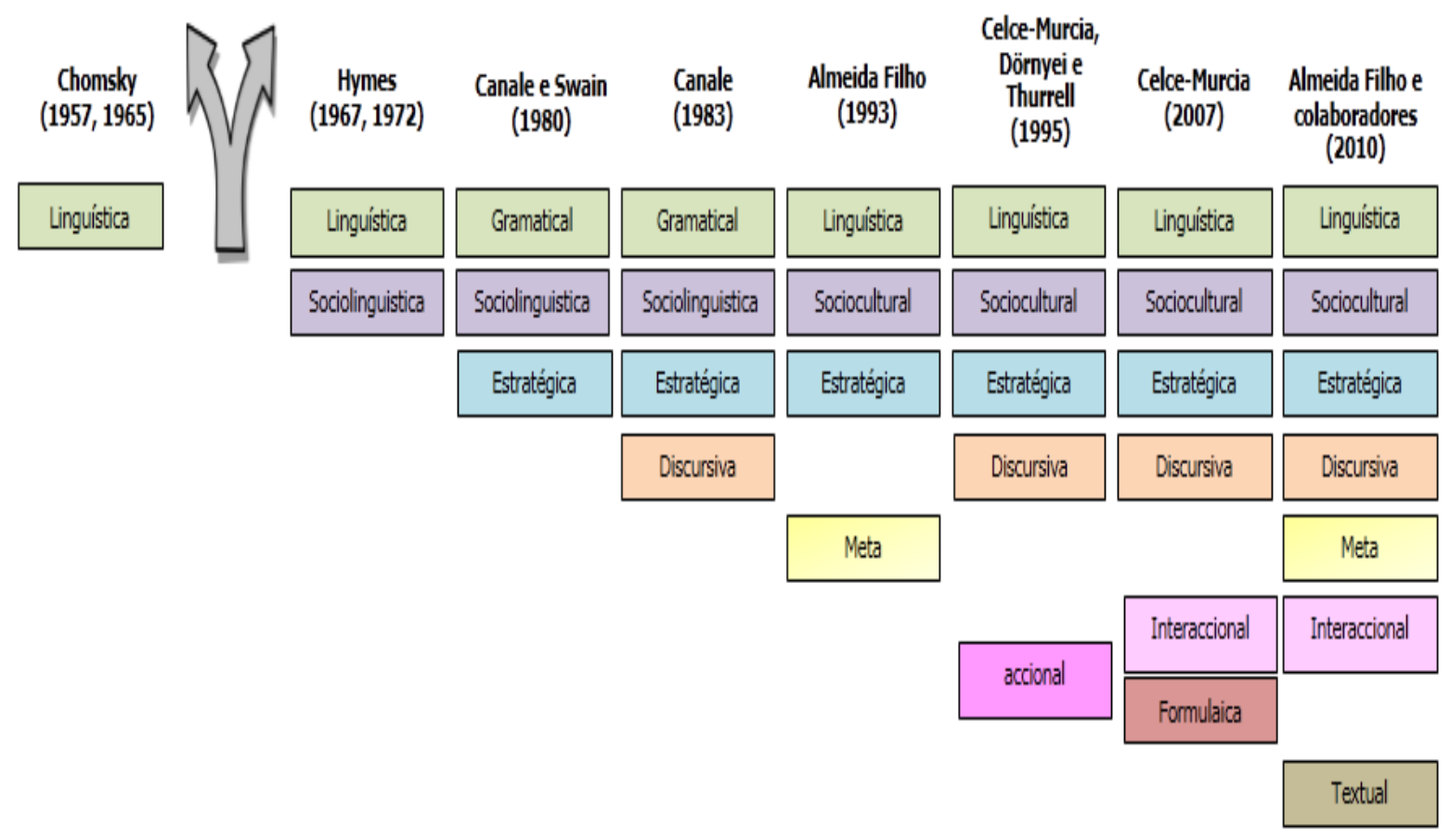

Fonte: Guimarães e Silva (2014) - com adaptações

No modelo teórico sugerido por Canale e Swain (1980), a CC é composta pelas competências gramatical, sociolinguística e estratégica. Entretanto, em 1983, Canale expande o conceito de $\mathrm{CC}$, incluindo nesse modelo a competência discursiva.

A competência estratégica é, para Canale e Swain (op. cit.), a capacidade de valer-se de estratégias verbais e não verbais para compensar alguma falha na comunicação, devido às condições limitadoras na comunicação real; e a competência discursiva, para Canale (op. cit.), é a capacidade de construir textos orais ou escritos, coerentes e coesos.

Ao construir uma relação entre as subcompetências mencionadas, podemos inferir que CC é a capacidade de um indivíduo para usar o código linguístico (competência linguística ou gramatical), para construir textos orais ou escritos, coerentes e coesos (competência discursiva) e utilizá-los em diferentes contextos socioculturais, com domínio das regras socioculturais de uso e regras do discurso (competência sociolinguística ou sociocultural), podendo valer-se de estratégias verbais e não verbais compensando algumas limitações na comunicação (competência estratégica).

Celce-Murcia, Dörnyei e Thurrell (1995), tomando como referência o modelo de Canale e Swain (1980) e Canale (1983), propõem, também, um modelo de CC. Algumas competências já identificadas permanecem no modelo de Celce-Murcia, Dörnyei e Thurrell (op. cit.), como as competências linguística (competência gramatical de Canale e Swain), discursiva e 
estratégica. Já a competência sociocultural, além de incluir as regras socioculturais de uso e regras do discurso (competência sociolinguística de Canale e Swain, 1980), passa a incluir outros fatores, que consideramos bastante válidos para o nosso trabalho, como os fatores sociocontextuais.

Os fatores sociocontextuais englobam: as variáveis dos participantes (idade, gênero, status, distância social, etc.), e variáveis situacionais (tempo, lugar, situação social); fatores estilísticos (convenções e estratégias de polidez, variação estilística como grau de formalidade e registro); fatores culturais (conhecimento da forma e da vida na comunidade, conhecimento de diferenças regionais e dialetais, convenções sociais, valores, crenças e consciência intercultural, etc.); fatores de comunicação não verbal (sinestésicos - linguagem corporal, sinais, tomadas de turno, gestos, expressões faciais, contatos corporal; proxêmicos - uso do espaço, distância; hápticos - toque; e paralinguísticos - tom da voz, som, ruídos, entonações, articulações, durações, pausas, ritmos, intensidades e o silêncio).

Os autores incluem, nesse modelo de CC, a competência acional, que é definida como a habilidade para transmitir e entender a intenção comunicativa ao realizar e interpretar enunciados e funções linguísticas (CELCE-MURCIA, DÖRNYEI e THURRELL, op. cit.)

Celce-Murcia propõe, em 2007, uma revisão desse modelo, no qual a competência acional é substituída pelas competências formulaica e interacional. A competência formulaica se refere a blocos de língua fixos e pré-fabricados amplamente usados em interações cotidianas, como as expressões idiomáticas, os ditados, os padrões de sentenças, frases e fórmulas memorizáveis. A competência interacional, por sua vez, engloba os enunciados e as tomadas de turnos.

Existem, ainda, as competências (organizacional, pragmática) e as estratégias metacognitivas que compõem a CC no modelo de Bachman (1990). Contudo, esse modelo não será definido neste trabalho por ser mais utilizado para avaliações de proficiência.

No Brasil, Almeida Filho (2010, p. 9) condensa “contribuições teóricas de autores básicos como Chomsky (1965), Hymes (1979), Canale e Swain (1980), Canale (1983), Tarone (1980) e Widdowson (1989), entre outros", apresentando um modelo de CC que inclui as competências linguística, sociocultural, meta e estratégica e "o desempenho dos participantes através do grau de acesso aos conhecimentos disponíveis". Para o autor, a competência meta refere-se aos conhecimentos metalinguísticos e metacomunicativos. O metalinguístico representa os "conhecimentos e as capacidades de citação de regras explícitas com nomenclatura específica aprendidas conscientemente” (p. 12), enquanto o componente metacomunicacional é caracterizado pela "capacidade do falante de uma língua de saber 
reconhecer e explicar verbalmente com taxonomia adequada aspectos relevantes da comunicação" (FRANCO e ALMEIDA FILHO, 2009, p. 12-13).

Além desse modelo de 1993, Almeida Filho criou, em 2009, com seus colaboradores no projeto "Pró-Formação (Análise e Formação de Professores e Alunos de Língua(s) via Abordagem e Competências)", no PPGLA na Universidade de Brasília (UnB), um arcabouço (figura 4) que contempla, além das competências já identificadas, a competência discursiva, a textual, a estratégico-formulaica e a estético-lúdica. A competência discursiva "é a capacidade de manutenção do fluxo discursivo entre usuários de uma dada língua para a compreensão e expressão de significados situados num contexto", a textual "caracteriza-se pela capacidade de composição e leitura de textos em gêneros distintos” e a interacional “ é a capacidade de colocar-se em comunicação com outros, seja ela oral ou por escrito" (FRANCO e ALMEIDA FILHO, op. cit., p. 12).

Figura 4 - Modelo de competência comunicativa, aprimorado em 2015 a partir do seu esboço em 2009

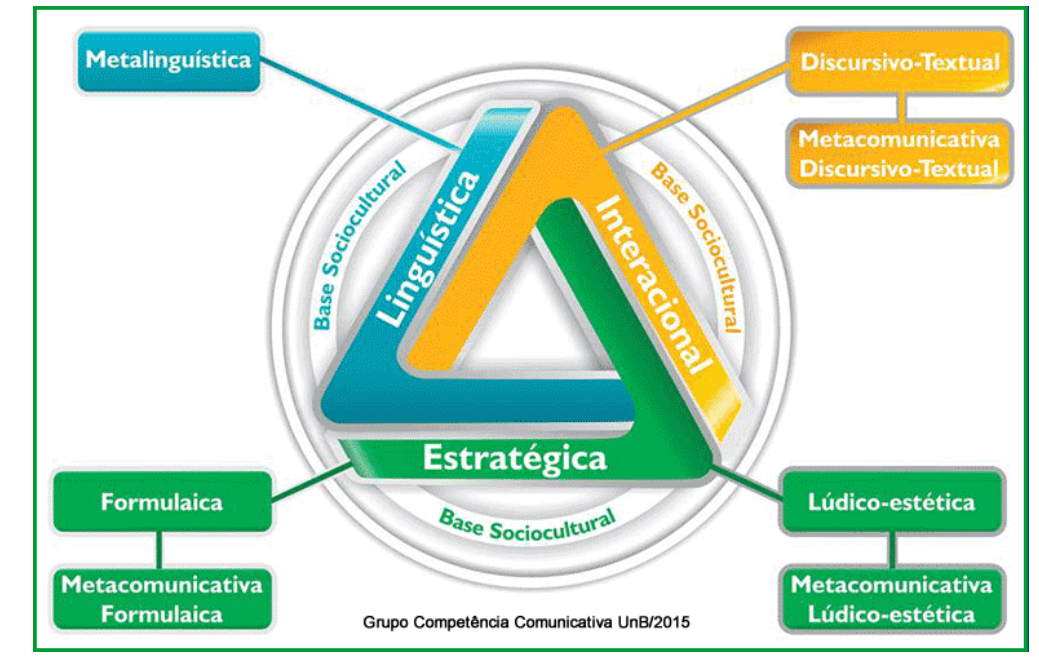

Fonte: http://let.unb.br/site-cc/home.html. Página eletrônica do PPGLA.

Ao apresentarem o modelo descrito acima, os autores trazem elementos que consideramos, assim como os autores, elementos"atômicos" da CC:

1. Conhecimento: saber, conhecimento de mundo e cultura, de como agir em relação ao outro em diversos contextos socioculturais;

2. Atitudes: Posturas assumidas diante da tarefa de ensinar ou aprender um dado idioma;

3. Capacidade de ação: capacidade de articulação de fala, de interação com falantes da língua-alvo (PPGLA, online).

Por entendermos que um construto teórico pode atender em maior ou menor grau a determinados contextos de ensino, decidimos, para o nosso trabalho, utilizar o modelo de Celce- 
Murcia (2007), por entendermos que a competência interacional e formulaica, bem como a competência sociocultural, atendem bem aos objetivos do nosso contexto (detalharemos esse aspecto no capítulo de análise de dados, ao descrever o nosso planejamento de curso).

$\mathrm{O}$ conceito de $\mathrm{CC}$, assim podemos concluir, gerou uma nova forma de ensinar, uma nova filosofia para o ensino de línguas: a Abordagem Comunicativa (AC). A AC se apoia, portanto, em princípios que consideram a língua em uso. Para Almeida Filho (2013, p. 58), a AC se caracteriza "por uma ênfase maior na produção de significados do que de formas do sistema gramatical", por meio de materiais, procedimentos e técnicas interativas com trabalhos em pares ou pequenos grupos que fazem o aluno pensar, interagir e expressar-se na L-alvo.

\footnotetext{
O ensino comunicativo é, assim, aquele que organiza as experiências de aprender em termos de atividades relevantes/tarefas de real interesse e/ou necessidade do aluno para que ele se capacite a usar a língua-alvo para realizar ações de verdade na interação com outros falantes-usuários dessa língua (ALMEIDA FILHO, op. cit. p. 56).
}

Entre as características trazidas por Almeida Filho (op. cit., p. 58-68), quanto ao ensino comunicativo, destacamos que este "apresenta temas e conflitos no universo do aluno na forma de problematização e ação dialógica; propicia experiências de aprender com conteúdos de significação e relevância para a prática e uso da nova língua", o que "abre ao aluno a possibilidade de se reconhecer nas práticas do que faz sentido para a sua vida, do que faz diferença para o seu futuro como pessoa". Isso, em termos práticos, fornece meios de interação, viabilizando o desenvolvimento da CC.

Não podemos desconsiderar que o processo de aprender línguas é um fato social e, como todo fato social, envolve sujeitos e contextos. A sala de aula é um desses contextos de interação entre os sujeitos, pois nela convivemos, (inter)agimos, trocamos experiências, acessamos o conhecimento e mobilizamos nossos saberes. A sala de aula deve permitir, portanto, um processo de interação social por meio da LE. Nesse sentido, Richards e Rodgers (2001) ressaltam a importância do ensino centrado no atendimento de necessidades e interesses dos alunos e também no encorajamento de sua participação no processo, por meio da promoção de sua autonomia. Meios pelos quais o aluno pode obter um melhor desempenho, uma vez que a centralidade no aluno e em suas necessidades tem sua importância acentuada, quando consideramos "o aluno como sujeito sócio-histórico portador de bens culturais" (BOURDIEU, 1996). Por isso, é necessário pensar em propostas para conduzir o processo de ensino e aprendizagem, tendo em vista as práticas sociais contemporâneas e o aluno como portador de bens (saber, valores, capacidades, experiências, etc.). 


\subsubsection{Operação Global de Ensino de Línguas (OGEL): o planejamento de curso}

Como vimos anteriormente, a nossa concepção de língua(gem), ensinar e aprender, se torna um forte elemento de influência em como planejamos os nossos cursos, como escolhemos ou produzimos os materiais didáticos, como construímos as experiências na sala de aula e ainda como avaliamos nossos alunos, conforme nos esclarece Almeida Filho (1993, 2012, 2013) sobre as quatro materialidades (dimensões) na OGEL. Todas essas dimensões do processo de ensinar são influenciadas, simultaneamente, pela abordagem de ensinar.

Figura 5 - Operação global de ensino de línguas (modelo OGEL)

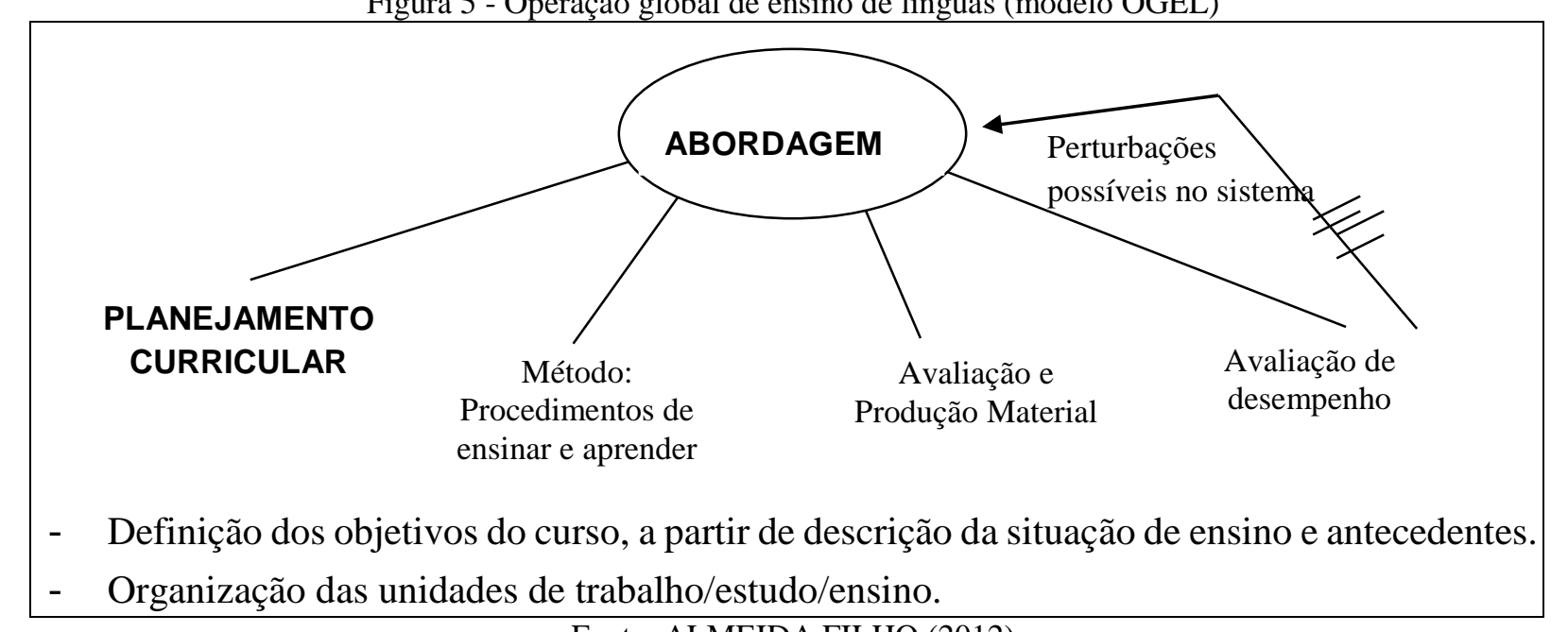

Fonte: ALMEIDA FILHO (2012)

Apesar do foco deste trabalho ser no planejamento de curso, é possível perceber que as demais dimensões estão interligadas. Sendo assim, concordamos com Almeida Filho (2013), quando este afirma que a produção e/ou seleção do material didático tem efeito retroativo sobre o planejamento curricular que, por sua vez, pode ter efeito proativo sobre o método escolhido e à forma de avaliar os alunos, e, assim sucessivamente, dependendo das decisões e ações adotadas pelo professor.

O planejamento de curso (de línguas) consiste em criar, selecionar e estruturar o ensino, guiado por uma dada abordagem. O processo de planejar cursos é, portanto, um ato do professor e o seu planejamento (de curso) é um guia que orienta toda a sua prática pedagógica ${ }^{27}$. $\mathrm{O}$ professor realiza e efetiva o seu planejamento e toma decisões e ações no contexto pedagógico

\footnotetext{
${ }^{27}$ ALVAREZ, Maria Luisa Ortiz. Nota de aula. Planejamento de curso e Avaliação de Materiais Didáticos. Em 22
} de setembro de 2014. 
guiado, também, por um conjunto de competências (ALMEIDA FILHO, 1993, 2014; ALVARENGA, 1999, 2014).

Para Menegolla e Santanna (1991, p. 13), “o ato de planejar é uma preocupação que envolve toda a possível ação ou qualquer empreendimento da pessoa. Sonhar com algo de forma objetiva e clara é uma situação que requer um ato de planejar”. Para os autores, todo o indivíduo faz planejamentos, logo, planejar é uma atitude nata do ser humano.

O ato de planejar do professor, para Haydt (2006), envolve analisar uma dada realidade e refletir sobre suas condições, o que possibilitará ao professor-planejador prever as formas alternativas de ação, a fim de alcançar os objetivos desejados. Para a autora, o professor, ao fazer o seu planejamento, antecipa todas as etapas de forma organizada.

Quanto ao planejamento do docente de LE, para alguns autores, o ato de pensar em termos de conteúdo, materiais, atividades, atmosfera de sala de aula, organização de novos conhecimentos deve ser direcionado para o mais importante de todo o processo de ensino e aprendizagem: os próprios alunos (ALMEIDA FILHO, 2012; VIANA, 2009; WAJNRYB, 1992; WOODWARD, 2001; GUIMARÃES, 1995). Além desses aspectos, Wajnryb (op. cit.) ressalta que o planejamento possui um caráter relativamente estático, mas a aula é dinâmica, implicando na alteração inevitável do planejamento no desenvolvimento da aula, o que corrobora com o exposto por Prabhu (2001), quanto à natureza dinâmica da aula. A autora (op. cit.) afirma que devemos pensar sobre questões relacionadas à motivação e autonomia dos alunos, interação entre os sujeitos e contextualização da língua para a sua prática.

A motivação é ativada, segundo Brown (2007), quando percebemos o valor (recompensa) e/ou necessidades de explorar o novo, estimular, conhecer, e está relacionada também à autoestima e à autonomia. A motivação, nesse sentido, é avaliada em termos de motivos intrínsecos e extrínsecos do aprendente. Aqueles que aprendem devido à percepção de suas próprias necessidades e objetivos são intrinsecamente motivados; e aqueles que perseguem uma meta apenas para receber uma recompensa externa recebem motivação extrínseca. Para o autor (op. cit.), é importante garantir que nosso fazer pedagógico possa gerar uma motivação intrínseca nos alunos, de modo a levá-los a esforçar-se, a ter autonomia e autorrealização.

A motivação, segundo Ribas (2008), pode ser evidenciada a partir de um comportamento. Para o autor (op. cit., p. 53) motivação é "um impulso, força, desejo ou estímulo, que varia de indivíduo para indivíduo e que o conduz à ação, fazendo-o se esforçar e persistir uma tarefa".

Woodward (op. cit.) destaca a relevância do envolvimento dos alunos em todas as decisões do planejamento e reforça a importância do professor escutá-los, observá-los, durante 
e após as aulas, e percebê-los como indivíduos. Guimarães (op. cit.) trata também da relevância do envolvimento e do compromisso do aluno no processo de aprendizagem, e sugere que o aprendiz deve estar consciente dos objetivos da aula, uma vez que informá-los sobre o que eles devem ser capazes de realizar ao fim da aula pode motivá-los, o que possibilitaria o seu maior engajamento.

Encontramos, nesses autores, uma preocupação da qual compartilhamos, a de comprometer os alunos no seu próprio processo de aprendizagem, por meio de um ensino que os envolva nas decisões sobre o que aprender (o que precisam, o que gostariam), como aprender (uso de procedimentos, técnicas, recursos) e de que forma (tipos de interação), podendo, assim, motivá-los a engajar-se com seu próprio aprendizado numa perspectiva do desenvolvimento de sua autonomia.

Dewey (1975) defende enfaticamente um currículo centrado no aprendiz com a participação efetiva do educador norteando o aprendizado de seus alunos. Dewey (op. cit.) argumenta que o professor desempenha seu papel de educador ao planejar previamente as atividades do grupo, ao preparar um ambiente que favoreça experiências satisfatórias para a construção do conhecimento e um ambiente que desenvolva as potencialidades dos educandos.

Pensando em formas de se criar experiências em sala de aula que coloquem o aluno no centro da aprendizagem, que impulsionem a comunicação e a interação entre os sujeitos e que focalizem a aprendizagem no sentido ao invés da forma, encontramos, nas últimas décadas, planejamentos que promovem esses ambientes, por meio de tarefas, projetos, jogos, teatro, estudos de caso, entre outros. Essas formas de planejamento com relações interativas em sala de aula buscam aproximar aprendiz e L-alvo, fazendo com que a nova língua seja, assim, "desestrangeirizada"; as atividades podem ter como ponto de partida a seleção de temas por parte dos alunos. Detalharemos mais adiante o planejamento que integra língua e conteúdo do próprio currículo do aluno e temas do cotidiano (Planejamento CLIL) combinando com uso de tarefas.

Para pensar em um planejamento de curso, a primeira etapa consiste em verificar quais são os objetivos dos alunos que, por sua vez, ajudarão na definição dos objetivos do curso. Esta é, portanto, a primeira etapa de um planejamento: o levantamento de objetivos (ALMEIDA FILHO, 2013; DUBIN e OLSHTAIN, 1986; VIANA, 2009). Segundo Almeida Filho (2012) para definir os objetivos de um curso, é necessário, também, que o professor conheça a situação ou contexto de ensino e seus antecedentes. Para isso, o professor-planejador deve buscar informações "sobre os alunos, história do curso, perfis de formação de professores que o implementarão, cultura de aprender dos alunos e cultura de ensinar da escola, papel da língua- 
alvo na comunidade" e informar esses dados para outros implementadores, pais e autoridades. O autor (op.cit, p.39) explica que "geralmente se coletam os registros com informações no próprio local com pessoas familiarizadas com a situação através de conversas, entrevistas e questionários" e apresenta, assim, um roteiro para o planejamento de cursos de língua, conforme figura a seguir.

Figura 6- Roteiro para a elaboração de um planejamento de curso de línguas

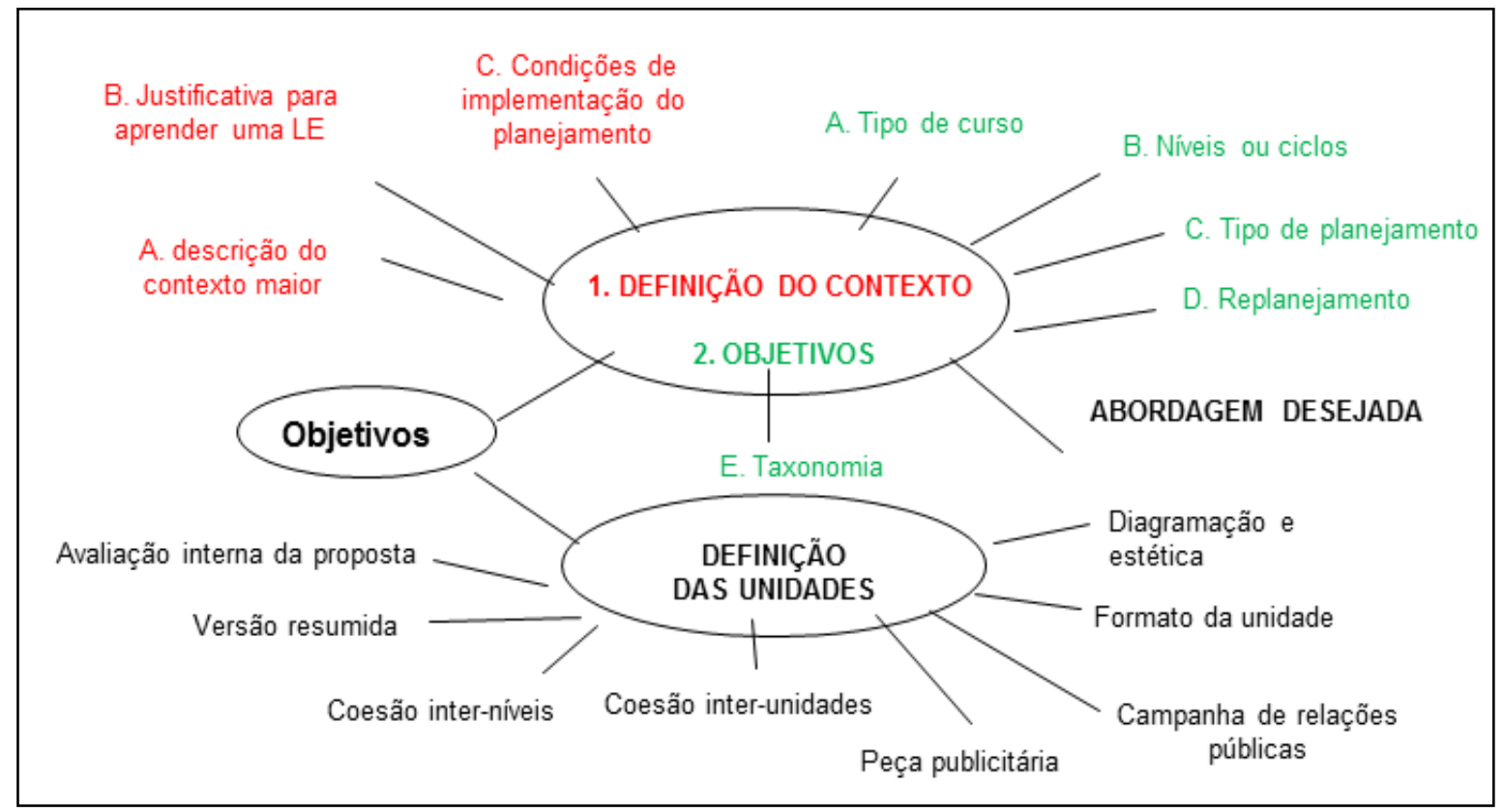

Fonte: Almeida Filho (2012, p. 35)

Consideramos, portanto, como tópicos essenciais para a organização do planejamento: a definição do contexto e objetivos de ensino. Para o contexto, há:
A. Descrição do contexto maior;
B. Justificativa para aprender uma LE;
C. Condições de implementação do planejamento.

Quanto aos dados do contexto, Viana (2009) apresenta a necessidade de se levantarem informações sobre questões de política educacional, número de aulas, recursos físicos e humanos. Para os objetivos, Viana (op. cit.) propõe o levantamento de aspectos individuais dos alunos - necessidades, interesses, fantasias (ALMEIDA FILHO, 1993, 2012,2013), desejos, motivações, conhecimento prévio, disponibilidade de tempo, entre outros. 
Com o levantamento desses objetivos e já de posse dos elementos do contexto, torna-se possível determinar os aspectos listados por Almeida Filho (2012) para o roteiro de planejamento, como:
A. Tipo de curso;
B. Níveis ou ciclos;
C. Tipos de planejamento;
D. Replanejamento (se for necessário);
E. Taxinomia.

Com todos esses elementos, é possível delinear uma unidade de ensino que se compõe dos seguintes aspectos (ALMEIDA FILHO, op. cit., p. 50-51):

- Definição da natureza das experiências que serão promovidas nas unidades e os conteúdos que estão implícitos nessas experiências;

- Diagramação e estética próprias que marcarão posteriormente os materiais;

- Definição dos elementos que darão coesão ao conjunto das unidades (coesão interunidades).

O levantamento do contexto e dos objetivos nos permite reconhecer a natureza do curso, ou seja, se é um curso de línguas para fins gerais ou para fins específicos (ELFE - Ensino de Línguas para Fins Específicos). Almeida Filho (op. cit., p. 43) explica que "quando os aprendizes demonstram possuir interesses, fantasias ou nenhuma delas, tem sido mais frequente a adoção do tipo geral de curso, ou seja, um programa para fins não óbvios ou difusos".

Assim, observando a OGEL, identificamos que "quando os objetivos são bem definidos e bem marcados passando do nível 4 (projeções) e 3 (fantasias) e englobando mais fortemente o nível 2 (interesses) e 1 (necessidades), podemos definir o curso como o ELFE" (GUIMARÃES, BARÇANTE e SILVA, 2015, p. 66). Para tanto, em um curso ELFE, os objetivos são bastante definidos, delimitados com necessidades e interesses dos alunos bem específicos e localizados. 
Figura 7 - Ensino de línguas para fins específicos x Ensino de línguas para fins gerais

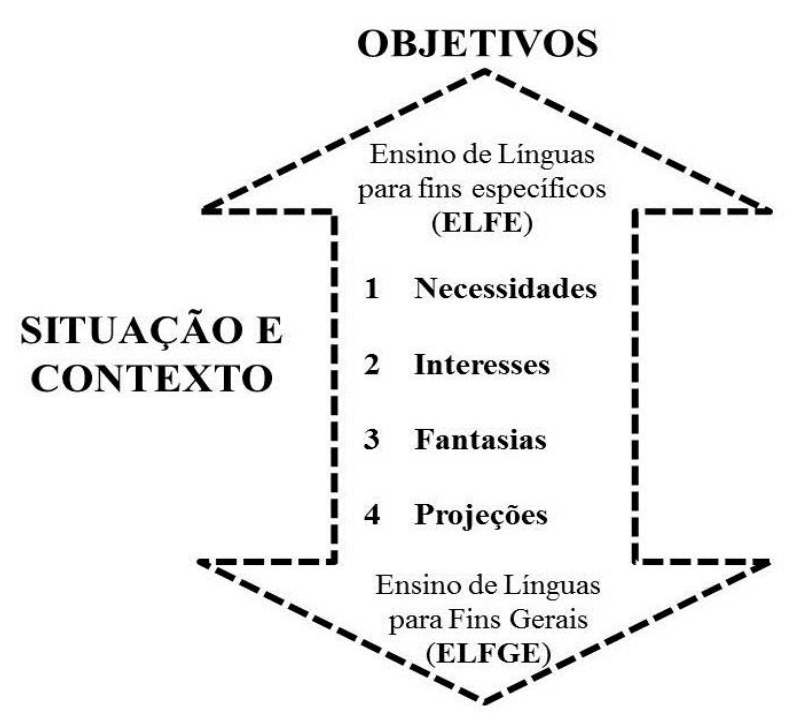

Fonte: Elaborado pela autora da dissertação para ilustrar, de forma didática, as informações acima mencionadas.

Todo curso de línguas deve buscar atender aos objetivos dos alunos, mas, no caso de um curso ELFE, a análise de objetivos se torna uma etapa imprescindível, pois é "essa análise que guia o planejamento desses cursos, indicando o que é específico com relação à LE” (AUGUSTO-NAVARRO, 2008). Por ser a análise de objetivo um dos fundamentos do ELFE, trataremos especificamente desse tema na próxima seção.

\subsection{ENSINO DE LÍNGUA PARA FINS ESPECÍFICOS}

Para este trabalho, entendemos ELFE como uma tipologia de curso/ensino específico que se opõe a outro tipo, o geral, já que sua natureza é definida a partir de objetivos e do contexto de ensino.

Encontramos, na literatura, um campo bastante amplo de diferentes perspectivas para o conceito de ELFE. A dificuldade de se definir o que seja exatamente o ELFE, talvez explique por que, a partir da década de 1990, esse tipo de ensino começa a ser criticado por uns e repensado por outros (AUGUSTO, 1997).

Para Hutchinson e Waters (1987), Ramos (2005), Celani, Freire e Ramos (2009), o ELFE deve ser considerado como uma abordagem para a aprendizagem de uma língua que se fundamenta na necessidade do aluno, para os autores: uma abordagem instrumental. Outros autores definem o ELFE como metodologia (AUGUSTO-NAVARRO, 2008; TERENZI, 2014). 
Como dissemos anteriormente, consideraremos a existência de duas vertentes/balizas/abordagens de ensinar línguas, a de base gramatical e a de base comunicativa. Dessa forma, consideramos que o ELFE não é de fato uma abordagem, mas um tipo de curso que se difere de outro, no qual o que determina sua natureza são os objetivos e o contexto.

O ELFE teve início durante a Segunda Guerra Mundial, realizado de maneira informal, com o propósito de ensinar as línguas europeias aos soldados. Entretanto, o seu ensino formal ocorreu somente após a Segunda Guerra Mundial, principalmente no estudo da língua inglesa que, de acordo com Howatt (1984), passou a ser adotada como a língua para assuntos relacionados ao comércio e à tecnologia. O estímulo para a sua metodização deve-se à necessidade de capacitação de imigrantes na reconstrução da Europa e à predominância do poder econômico norte-americano pós-guerra, pela demanda de um mundo em transformação ocasionada pelos desenvolvimentos científico-tecnológicos, pelas novas pesquisas na área de Linguística Aplicada (LA) e os avanços na Psicologia Educacional, que enfatizam a importância de um ensino com o foco no aluno e em suas necessidades (HUTCHINSON e WATERS, 1987; RAMOS, 2005).

No Brasil, o ELFE surgiu com o Projeto Nacional Ensino de Inglês Instrumental em Universidades Brasileiras (Projeto ESP) ${ }^{28}$, entre os anos de 1978 a 1989, na Pontifícia Universidade Católica de São Paulo (PUC/SP). As necessidades dos alunos das 26 universidades brasileiras que participaram do Projeto ESP apontaram para a leitura de textos e literatura especializada. Desse modo, por ter sido a "leitura a habilidade identificada como a única necessária, a decisão foi focalizá-la (...) então, priorizou a habilidade de leitura, o ensino estratégico, a leitura de textos autênticos” (RAMOS, op. cit., p. 115). Ainda segundo a autora (op. cit.), o grande desafio do Projeto foi, portanto, o de "implementar o ensino de uma única habilidade, em detrimento do ensino das quatros habilidades" (ler, escrever, ouvir e falar).

Assim, como a necessidade dos alunos do Projeto ESP da PUC foi a leitura de textos acadêmicos e científicos em língua inglesa de áreas específicas, conforme Freire (2009) e Ramos (op. cit.), se construiu em nosso país a crença, o mito de que ensino Instrumental ${ }^{29}$ é o ensino de leitura e/ou de estratégias de leitura, apesar do ensino instrumental ser um tipo de

\footnotetext{
${ }^{28}$ Projeto Nacional Ensino de Inglês Instrumental em Universidades Brasileiras (Projeto ESP). A sigla ESP faz referência ao inglês (English for Specific Purposes). O Projeto foi dirigido pelo Britsh Council, em convênio com a PUC/SP, com auxílio da CAPES e CNPq. O livro The Brazilian ESP Project an Evaluation de 1988, editado por Holmes, Ramos, Scott e pela coordenadora do Projeto Maria Antonieta Celani (PUC/SP), retrata a história do Projeto.

${ }^{29}$ Neste trabalho, ao citar o termo Instrumental como um tipo de ensino, passaremos a grafá-lo em itálico, dado que, em outros momentos, utilizamos instrumental no sentido de Habermas (2012) como um tipo de agir.
} 
ensino, com o foco nas necessidades dos alunos, que pode ser para leitura, como no Projeto PUC, ou para outras necessidades de uso da L-alvo.

Para Ramos (2014, informação verbal ${ }^{30}$ ), o mito de que um curso dedicado ao ensino da leitura é Instrumental deve ser superado, uma vez que esse mito gera inquietações entre professores e pesquisadores. Uma alternativa para a autora talvez seja o de aceitar o termo Instrumental como sinônimo de leitura e, portanto, uma entre outras possibilidades de fins específicos.

Além do mito que instrumental é leitura, segundo Ramos (2005, p. 116-117) outros mitos foram surgindo quanto ao ensino Instrumental, na medida em que ele foi crescendo no Brasil. A autora aponta, por exemplo, o mito de que nele se ensina uma única habilidade e de que essa é Inglês Técnico. Além desses, existem outros mitos de cunho metodológico, por exemplo: que não se faz o uso de dicionário; que não se ensina gramática; e, que o curso tem que ser ministrado em língua materna. Há outro mito que não é decorrente do Projeto, mas de uma visão que muitos professores têm do processo de ensino e aprendizagem: que só deve se ensinar ELFE depois que o aluno já dominou o "básico" da língua, e, por último, que a aprendizagem é "manca”, pragmática, utilitária e que não considera o ser humano por completo, dado que o Projeto PUC lidava apenas com uma das habilidades.

Augusto-Navarro (2008, p. 123) corrobora com alguns desses mitos, os quais nomeia de ideias errôneas, como o de que "ensino instrumental de LE é ensino de leitura; cursos instrumentais de línguas devem ser dados em língua materna, devem trabalhar sempre e exclusivamente uma das quatro habilidades (reading, writing, listening e speaking)", e acrescenta outas ideias bastante difundidas, entre elas as de que a análise de necessidades deve ser realizada somente para a preparação dos cursos; que tem como identificar o nível de proficiência do aluno na habilidade prioritária; e que a motivação já está garantida por ser um curso instrumental.

O modelo ELFE leitura passou a ser adotado em outras universidades e escolas técnicas e tecnológicas, sem se observar que o modelo instrumental (leitura) do Projeto atendia àquela realidade no final da década de 1970 (acesso às bibliografias da área de atuação), e não necessariamente a outras realidades e aos objetivos contemporâneos (op. cit.). Augusto-Navarro (op. cit.) afirma que existem contextos em que ainda é necessário priorizar a leitura e conduzir as aulas em língua materna, mas ressalta que o pesquisador brasileiro, na contemporaneidade,

\footnotetext{
${ }^{30}$ RAMOS, Rosinda. III Congresso Nacional de Línguas para Fins Específicos, 2015, Rio de Janeiro, em 13 de março de 2015.
} 
precisa e almeja mais do que estratégias de leitura e se interessa por cursos com foco em uma das habilidades, sem negligenciar as demais. Em um curso de ELFE, "uma habilidade pode ser o objetivo central, mas as demais podem ser trabalhadas colateralmente, inclusive dando suporte ao desenvolvimento da habilidade prioritária" (AUGUSTO-NAVARRO, 2008, p. 119120). Para a autora (op.cit), não existe sentido em se segmentar a língua em habilidades. Nesse tipo de curso, deve-se apenas mudar o foco central de acordo com a necessidade mais pertinente em cada momento.

Della Rosa (2013), por exemplo, identificou algumas mudanças na contemporaneidade para as necessidades acadêmicas dos alunos brasileiros. Em sua pesquisa buscou levantar e discutir os interesses e necessidades de pesquisadores (mestrados e doutorados) em relação ao aprendizado da língua inglesa visando a contribuir para o desenvolvimento de cursos/materiais voltados para o ensino de LE nesse contexto. Observou que "as necessidades e interesses não variam de um nível para outro, mas podem variar de uma área para outra” (p. 131-132). Em sua pesquisa, a maioria dos participantes expressa à necessidade de publicar em língua inglesa e reforça a importância do desenvolvimento da escrita e, apesar de reconhecer a importância de precisar aprimorar na leitura, as expectativas são de aperfeiçoar a escrita e a oralidade.

O que pode ser observado em algumas ementas de cursos de graduação e pós-graduação e em cursos técnicos e tecnológicos no Brasil é um ensino que prioriza apenas a leitura, sem um prévio levantamento das necessidades. Nesse caso, conforme já afirmava Ramos (2005, p. 119), o princípio definidor do ELFE - análise de necessidades - foi esquecido. Porém, atualmente é possível perceber uma preocupação por parte dos professores e pesquisadores de atender às necessidades contemporâneas. Alguns trabalhos na EPT já têm buscado delinear o curso ELFE por meio do mapeamento de necessidades dos alunos (MOREIRA, 2012; TERENZI, 2014; BRASIL, 2013).

Moreira (op. cit.) buscou conhecer as necessidades de um grupo de alunos do curso tecnológico em Gestão Empresarial para fornecer subsídios às propostas futuras de adequação e reelaboração do plano de curso vigente. Terenzi (op. cit.), por sua vez, investiga a relação entre o planejamento de um curso em contexto tecnológico (aviação), a partir de seus documentos legais e os objetivos da instituição, do mercado de trabalho e das necessidades e interesses dos alunos, e apresenta seis princípios norteadores com o potencial de orientar o ensino de LE na EPT de nível superior (p. 143):

- a análise de necessidades deve ser uma atividade anterior ao planejamento, mas deve ser contínua; 
- a análise de necessidades deve contemplar diferentes perspectivas, a partir de múltiplos métodos e fontes, considerando os envolvidos;

- a aprendizagem de uma língua para propósitos específicos deve ser significativa, coerente com interesses e necessidades;

- as estruturas linguísticas e o vocabulário devem ser trabalhados de acordo com os gêneros recorrentes na área específica;

- uma das habilidades (ler, escrever, ouvir e falar) pode ser enfatizada, porém não se deve excluir as demais; e,

- deve-se sensibilizar o aprendiz acerca dos propósitos específicos que são base para o ensino da língua.

Brasil (op. cit.) busca identificar e analisar as necessidades e os interesses de alunos do Ensino Médio Técnico Integrado, em relação à aprendizagem da língua espanhola para o planejamento de um curso de extensão da área técnica de Edificações. Os resultados apontam para uma necessidade de projeção acadêmica de "estudar espanhol para o vestibular" e uma projeção profissional "estudar espanhol para aproveitar futuras oportunidades de trabalho", com interesse em "aprender a falar a língua espanhola".

Nessa perspectiva, para o ensino e planejamento de um curso de ELFE, alguns princípios são e devem ser considerados. Ramos (2005) apresenta os princípios definidos a seguir:

- aprendizagem centrada no aluno;

- levantamento de necessidades do aluno como ponto de partida para a elaboração de cursos; e, - temas e conteúdos relacionados às áreas de atuação do aluno (acadêmicas ou profissionais).

Além disso, a autora (op. cit.) acrescenta algumas necessidades futuras em relação a esse tipo de ensino: formação do cidadão; as novas exigências tecnológicas, apontando, assim, para a capacitação do aluno para "agir no mundo por meio da tecnologia" (p. 110); e renovação de currículo. Para a autora, essas características apresentadas apontam para:

a confluência de vários aspectos desejáveis, como por exemplo, o indivíduo como centro do processo de ensino e aprendizagem, um processo voltado para a satisfação de necessidades identificadas nos contextos de atuação do indivíduo, conteúdos voltados para esses contextos, sejam eles profissional e/ ou acadêmico, preocupação em tornar o indivíduo um aluno autônomo, em outras palavras um ser que se coloca no mundo como aprendente" (p. 114). 
Para a definição dos objetivos dos alunos, o procedimento de análise de necessidades tem sido indicado por muitos estudiosos (HUTCHINSON e WATERS, 1987; DUDLEYEVANS e ST. JOHN, 1998; ROBINSON, 1991; AUGUSTO, 1997; AUGUSTO-NAVARRO, 2008; e RAMOS, 2005), como um dos elementos fundamentais e imprescindíveis para a elaboração de um curso ELFE.

O que chamamos de análise de objetivos, neste trabalho, é chamado na literatura de análise de necessidade (AN). Decidimos chamar de análise de objetivos, por entender que as necessidades se encontram dentro dos objetivos, assim como os interesses, fantasias e projeções. Esses são definidos no dicionário Glossa-LA, como:

$\checkmark$ Necessidades: razões objetivas para o estudo e aprendizagem da língua-alvo, geralmente vinculada a uma ocupação ou atividade prevista para ser realizada no mundo do trabalho ou estudos.

$\checkmark$ Interesses: Razões de inclinação por certos tópicos e temas desenvolvidas no aprendiz ou por ele(a) no curso das experiências vividas ou conhecimento internalizado.

$\checkmark$ Fantasias: Razões de ordem subjetiva, afetiva ou emocional, que se apresentam para mover o aprendiz na direção do aprender ou que sirva, pelo menos, para despertar-lhe o desejo de aprender uma (outra) língua.

$\checkmark$ Projeções: razões de estudo ou vivência de uma nova língua, percebidas como objetivos relevantes pelo professor ou planejador e que não foram detectadas pelo exame de necessidades, interesses ou fantasias dos aprendizes.

Para Dudley-Evans e St. John (1998), a análise de necessidades procura "identificar informações profissionais e pessoais sobre os aprendizes" (p. 16). Nesse caso, entram em discussão os níveis e as deficiências linguísticas, os meios efetivos de aprendizagem, o que se deseja de um curso e o meio em que ele é desenvolvido. Também se pode considerar o que os próprios alunos gostariam de alcançar ao final do curso.

Hutchinson e Waters (op. cit.) dividem a análise de necessidades em dois grupos: as necessidades-alvo - o que o aprendiz precisa fazer na situação-alvo -; e as necessidades de aprendizagem - o que o aprendiz precisa aprender para atuar na situação-alvo. Os autores fazem subdivisões das necessidades: necessidades (needs), propriamente ditas da situação-alvo; o que os alunos precisam - carência (lacks); e o que eles querem - desejos (wants). Para os autores (op. cit.) identificar as necessidades não é suficiente, precisamos saber também o que o aluno já sabe, para que possamos então decidir quais são as suas deficiências, fraquezas e carências. 
Os desejos são as motivações intrínsecas dos alunos relacionadas à aprendizagem da LE, independente da real necessidade de uso linguístico. Ou seja, os desejos apresentam natureza fortemente subjetiva. Essas aspirações são o que os alunos querem ou acham que precisam aprender.

Necessidade e interesse, para Augusto-Navarro (2008), são fenômenos distintos e podem ou não estar integrados, ou seja, uma necessidade pode gerar interesse, mas não é garantia para tanto. A autora (op. cit.) sugere que essa análise seja processual, investigando-se todo o ambiente e os contextos de uso da L-alvo na vida profissional e/ou acadêmica dos alunos, bem como o nível de conhecimento linguístico dos alunos.

Para a realização dessa análise, os instrumentos mais frequentes são questionários, entrevistas, observação, textos, consultas informais com empregadores, alunos e outros (HUTCHINSON e WATERS, op. cit.). Existe, também, a análise documental, que considera o que é produzido na área específica, como as publicações, seminários, correspondências, fóruns de discussão, etc.; e a análise da situação-alvo, em que se examinam os ambientes nos quais a língua-alvo é usada (ROBINSON, 1991 apud AUGUSTO-NAVARRO, 2008). Essa análise não deve ser vista como uma atividade acabada, pois deve ser contínua durante todo o processo.

É possível fazer o recorte comunicativo de uma determinada situação-alvo e verificar quais habilidades estão ali presentes, isto serve para guiar e facilitar o planejamento de curso, bem como a produção de materiais didáticos e as avaliações. É a partir desse recorte comunicativo (porque os recortes são as "habilidades" ações integradas) que podemos construir o syllabus e definir a ênfase em relação às habilidades que serão trabalhadas no curso, em maior ou menor proporção e definir o modelo teórico de CC.

Figura 8- Análise de objetivos: sua relação com recortes comunicativos e habilidades linguísticas

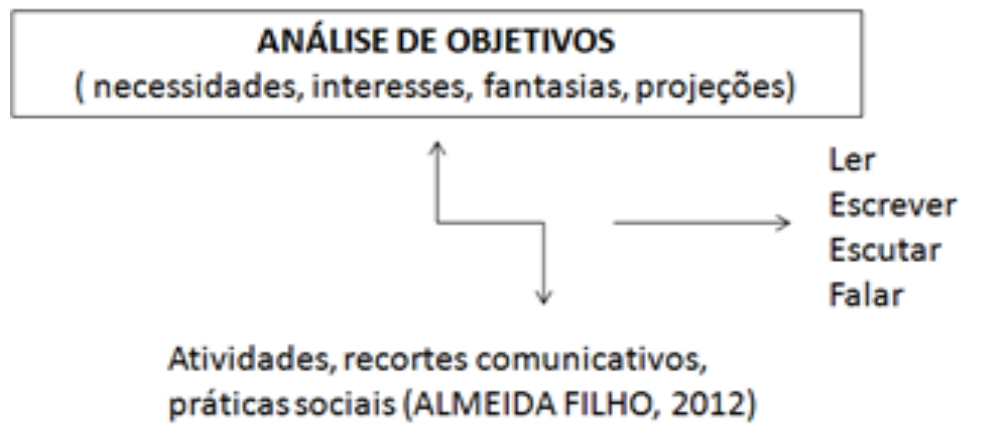

Fonte: Guimarães, Barçante e Silva (2014)

Para o nosso trabalho, consideramos que, ao realizar uma análise de objetivos, estamos levantando as necessidades dos alunos em relação ao que acreditam que precisam saber para 
atuar em sua área em LE e seus interesses (mais subjetivos), o que gostariam de aprender, de estudar, de saber, não necessariamente o que precisam saber. Além disso, destacamos as necessidades da própria situação-alvo (situação em que os alunos atuarão profissionalmente), levantadas pelos diversos instrumentos já mencionados.

\subsubsection{ELFE na Educação Profissional e Tecnológica}

Tratar de planejamento de curso de línguas na EPT envolve discutir sobre o ensino para fins específicos, neste caso para fins profissionais e formação para o trabalho.

O objetivo de um curso ELFE define ainda a sua tipologia. Na literatura, podemos encontrar o ensino de ELFE principalmente para fins acadêmicos e profissionais e algumas de suas variações.

Hutchinson e Waters (1987) assim o definem:

$\checkmark$ Fins acadêmicos;

$\checkmark$ Fins ocupacionais;

$\checkmark$ Para Ciência e Tecnologia; e

$\checkmark$ Para Negócios e Economia.

Para Robinson (1991), podemos dividir o ELFE em:

$\checkmark$ Fins acadêmicos (geral ou específico para uma disciplina);

$\checkmark$ Fins profissionais (negócios, social e tecnologia); e

$\checkmark$ Fins vocacionais (formação para o trabalho e formação linguística).

E, por fim, para Dudley-Evans e St. John (1998):

$\checkmark$ Fins Acadêmicos: para a Ciência e Tecnologia, Fins Médicos, Fins Jurídicos, Finanças e Economia; e

$\checkmark$ Fins Ocupacionais:

○ Fins Profissionais: Fins Médicos, para Negócios;

○ Fins Vocacionais: Vocacional e Pré-vocacional.

Tomando como base as possíveis divisões em tela, consideramos que o nosso curso de espanhol para futuros técnicos em Logística possa ser classificado como um curso para "fins profissionais" (VIAN JR, 2008; MARQUES e GARÍLLIO, 2008); “fins ocupacionais"; ou, 
ainda, para "fins vocacionais" (formação para o trabalho), para Negócios (VIAN JR, 1999; 2014) por se tratar do ensino de línguas na EPT em um curso do eixo Gestão e Negócios.

Apesar do ensino para fins profissionais ter tido sua sistematização somente durante e após a Segunda Guerra Mundial, alguns indícios foram citados por Howatt (1984), ainda no século XVI, com a necessidade de se ensinar inglês para negócios (termos comerciais, correspondências comerciais) aos protestantes que vieram para a Inglaterra. No Brasil, por sua vez, o ensino de línguas para negócios foi implementado a partir de 1759, com o Marquês de Pombal. Uma das primeiras medidas tomadas por meio das Reformas Pombalinas foi a criação das "Aulas de Comércio", que incluíam a aprendizagem de línguas estrangeiras para fins comerciais. No entanto, em 1765, o ensino de LE foi excluído e passou a ser exigido somente aos candidatos que tentavam ingressar nas Aulas. Em seu regulamento, as Aulas de Comércio (1759 - 1846) versavam sobre aritmética, câmbio, pesos, medidas, seguros e métodos de escrever livros ou partidas dobradas (termo usado em contabilidade para o registro das transações financeiras), gestão e as rotinas mercantis. A língua estrangeira era ensinada no curso com o objetivo de "viabilizar transações comerciais, tradução de textos, redação de cartas de mercancia, apólice de seguros, entre outros textos comerciais" (TELES, 2012, p. 12).

Podemos considerar o ensino de línguas nas Aulas de Comércio na Formação do Perfeito Negociante, entre 1759 a 1846 (TELES, op. cit.), como o momento embrionário de ELFE para o trabalho.

É interessante percebermos que a palavra trabalho pode apresentar várias interpretações. No dicionário Aurélio, seu significado está ligado à aplicação de força e faculdades humanas para alcançar um determinado fim. A história do trabalho é intrínseca à da sociedade porque é ele que nos proporciona as condições de sobrevivência e, mais do que isso, de produtividade criativa que faz bem à nossa autoestima e (con)vivência social.

Muitos dos fundamentos que norteiam a organização curricular da EPT trazem o debate do compromisso da educação com a adoção do trabalho como princípio educativo. O trabalho como princípio educativo advém, segundo Bezerra (2012, p. 51), “da compreensão de que é através do processo do trabalho que o homem humaniza-se e através dessa unidade ele se constrói”. Essa visão, do trabalho como princípio educativo, segundo Saviani (1989, 2003), passaria pela noção de politecnia, conceito que se baseia no rearranjo dos saberes sobre o trabalho, o que possibilita a universalização dos conhecimentos gerais, sem que eles fiquem limitados a uma única atividade, profissão ou classe. Entretanto, reforça Saviani (2003) que a formação integrada não deve abandonar de todo a necessidade de inserção dos trabalhadores na vida produtiva, pois é dela que estes retiram sua subsistência. É exatamente o oposto, é integrar 
a atividade intelectual ao trabalho produtivo formando trabalhadores capazes de atuar como dirigentes e cidadãos.

Percebemos, nesse sentido, a estrita relação do trabalho com outras temáticas, como trabalho, ciência, cultura, tecnologia, elementos indissociáveis para uma formação integral humana, conforme pontuam vários autores (FRIGOTTO, CIAVATTA e RAMOS, 2012; MOURA, 2010) sobre os objetivos da EPT, segundo, também, a própria legislação vigente.

Para Moura (2012), a tecnologia passou a ter um lugar central em quase todas as práticas sociais e cotidianas, assumindo uma dimensão sociocultural. A cultura constitui o modo de vida das pessoas, e é por meio dela que produzimos significados que definem nossas práticas sociais. Para tanto, o autor (op. cit.) avalia que a formação integrada precisa ir além de proporcionar o acesso aos conhecimentos científicos e tecnológicos produzidos e acumulados pela humanidade. Nas palavras do autor, a formação

precisa promover o pensamento crítico-reflexivo sobre os códigos de cultura manifestados pelos grupos sociais ao longo da história, como forma de compreender as concepções, problemas, crises e potenciais de uma sociedade e, a partir daí, contribuir para a construção de novos padrões de produção de conhecimento, de ciência e de tecnologia, voltados para os interesses sociais e coletivos (p. 5).

Para isso, Franco (2008) defende que a prática docente e a organização curricular na EPT devem ser obrigatoriamente emancipatórias. A emancipação, segundo a autora, supõe que o ser humano seja sujeito do seu próprio agir, capaz de pensar como sujeito.

Sacristán (2000) aponta que, para atender interesses emancipatórios, o currículo deve ser entendido como uma práxis e elenca os elementos de um currículo como configurador da prática, identificados por Grundy (1987):

a) a prática sustentada pela reflexão, que se constrói da interação do refletir e atuar;

b) um currículo que não se separa de sua realização em condições concretas;

c) um ambiente de aprendizagem como algo social, entendendo a interação entre ensino e aprendizagem dentro de determinadas condições;

d) o conteúdo do currículo como construção social, que leve os alunos a participar da elaboração de seu próprio saber, refletindo sobre o conhecimento, incluindo o do professor; e

e) a práxis como um processo de criação de significado como construção social, não carente de conflitos, pois o significado acaba sendo imposto pelo que tem mais poder de controlar o currículo (GRUNDY, 1987 apud SACRISTÁN, 2000, p.48).

Sacristán (op. cit.) reforça essas ideias de Grundy (1987) quando pontua que a melhoria da prática implica priorizar um quadro curricular que sirva de instrumento emancipatório, pois a prática controlada e a falta de autonomia afetam os envolvidos nas práticas curriculares, em 
especial professores e alunos. Para Santomé (1998, p. 11), as práticas pedagógicas devem ser construídas integrando "conceitos como a globalização, a interdisciplinaridade, os temas transversais, a educação mundial, os projetos, os centros de interesse, etc.”. Para o autor (op. cit., p. 15) as competências psicológica e cognitiva do ser humano "são fruto da interação constante que mantém com um meio ambiente culturalmente organizado (...) graças às suas múltiplas oportunidades de estabelecer relações interpessoais com os agentes mediadores" que o ser humano se constrói.

Giroux (1997) aborda certas questões e preocupações que são relevantes para a construção de uma pedagogia para a emancipação do sujeito. $\mathrm{O}$ autor sustenta que o professor como intelectual transformador deve estar comprometido com o ensino como prática emancipadora, possibilitando que os alunos desenvolvam "uma imaginação social e coragem cívica capaz de ajudá-los a intervir em sua própria autoformação, na formação dos outros e no ciclo socialmente reprodutivo da vida em geral" (p. 17). Assim, para o autor, é fundamental a implementação de políticas educacionais baseadas em um contexto crítico, reflexivo, gerador de autonomia, emancipação e transformação social. Isso significa tornar o político mais pedagógico que, nas palavras do autor,

\footnotetext{
significa utilizar formas de pedagogia que incorporem interesses políticos que tenham natureza emancipadora; isto é, utilizar formas de pedagogia que tratem os estudantes como agentes críticos; tornar o conhecimento problemático; utilizar o diálogo crítico e afirmativo; e argumentar em prol de um mundo qualitativamente melhor para todas as pessoas. Em parte, isto sugere que os intelectuais transformadores assumam seriamente a necessidade de dar aos estudantes voz ativa em suas experiências de aprendizagem. Também significa desenvolver uma linguagem crítica que esteja atenta aos problemas experimentados em nível da experiência cotidiana, particularmente enquanto relacionados com as experiências pedagógicas ligadas à prática em sala de aula (p. 163).
}

Assim, como os autores acima citados, entendemos a sala de aula como um espaço social no qual o aluno deve ser convidado a criar significados e reflexões, trazer a sua percepção de mundo, compartilhar saberes, experiências e desenvolver-se psicologicamente e cognitivamente e tornar-se autônomo e crítico, com vistas à emancipação. Sendo assim, a emancipação do sujeito-aluno tem uma relação direta com o ganho de autonomia, adquirida por meio do "agir comunicativo" e do "entendimento" (HABERMAS, 2012).

Isso considerado, percebemos que alguns tipos de planejamento de curso para o ELFE cabem mais na EPT do que outros. Para o nosso trabalho, optamos pelo planejamento CLIL por tarefas o qual detalharemos a seguir. 


\subsection{PLANEJAMENTO CLIL (APRENDIZAGEM INTEGRADA DE CONTEÚDOS/TEMAS E LÍNGUA) POR TAREFAS}

CLIL (Content and Language Integrated Learning) ou AICL (Aprendizagem Integrada de Conteúdos/Temas e Língua) é um termo guarda-chuva que abarca qualquer ensino dual de conteúdo e língua em qualquer contexto educacional, desde a educação infantil até a educação de jovens e adultos, sendo, portanto, flexível e dinâmico (DO COYLE, 2006).

Verdugo (2011, pp. 9-15-16) apresenta algumas dessas variedades que ilustram um contínuo que vai desde imersão total até aulas baseadas em temas:

(1) Imersão total ou parcial - uma parte, a maioria ou todo o conteúdo é ensinado por meio de uma L-alvo;

(2) Disciplinas do currículo - o conteúdo curricular pode ser ensinado através da L-alvo, o que pode incluir temas como cidadania, design e tecnologia, estudos ambientais, etc.;

(3) Momentos de uso de LE - uma área da disciplina curricular é ensinada em LE, de maneira regular e contínua, durante 15 ou 30 minutos, várias vezes por semana; e

(4) Aulas de LE baseadas em unidades temáticas - o planejamento é baseado em temas ou conteúdos curriculares.

Figura 9 - Contínuo de CLIL

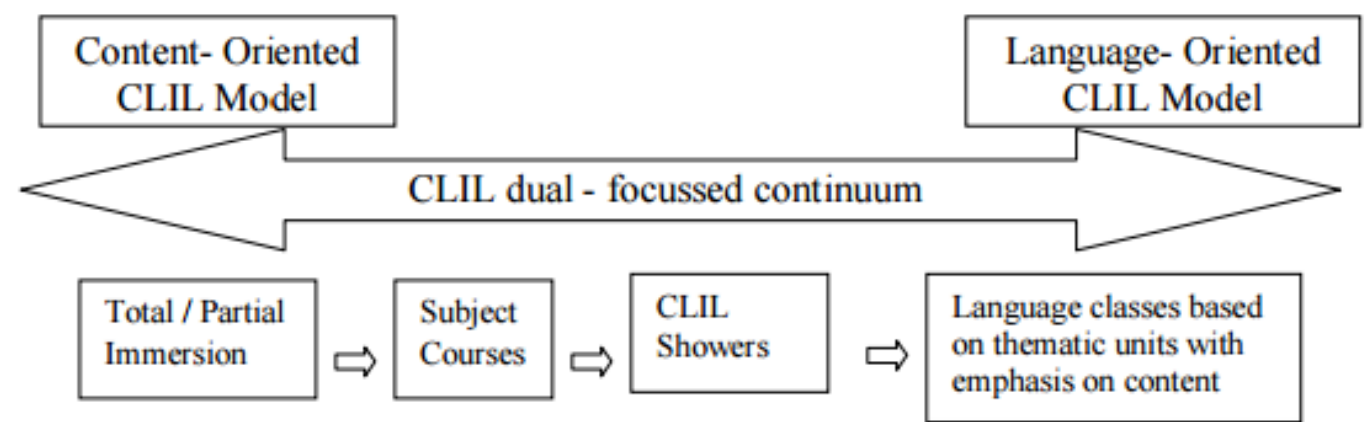

Fonte: Guidelines for CLIL Implementation in Primary and Pre-Primary Education (2011, p. 16).

Marsh (2000, p. 6) afirma que

no CLIL a aprendizagem da língua e outros assuntos são misturados de uma forma ou de outra. Isto significa que, na aula, existem dois objetivos principais, um relacionado com o assunto, tópico ou tema e outro ligado à língua. Eis porque CLIL é às vezes chamado de educação dual-focused (...).

A prática do CLIL pode ser diversificada, recebendo variações em sua implementação, dependendo de características nacionais, regionais, locais e das políticas de ensino (VERDUGO, 2001). O nosso trabalho encontra-se na última proposta de CLIL (apresentada no 
seu contínuo): aulas de LE baseadas em unidades temáticas com conteúdos curriculares de formação técnica e temas cotidianos e relevantes para os alunos, combinadas com o ensino por tarefas.

Alguns princípios ou dimensões foram identificados na literatura como fundamentais para a organização do planejamento CLIL em qualquer das variedades e em qualquer contexto: multilíngue, bilíngue, transacional, pluricultural, multicultural, globalizado, etc. Marsh, Maljers e Hartiala (2001, p. 217), por exemplo, apresentam o resultado de um projeto de investigação que buscou identificar essas "dimensões ou princípios educativos que inspiram diversos programas de CLIL na Europa", e, como resultado, identificaram entre esses programas a relação entre 5 dimensões: cultura, ambiente, língua, conteúdo e aprendizagem; trazendo algumas características relevantes de cada uma delas (p. 209).

A. Cultura: (1) Constrói conhecimentos e compressão de diferentes culturas, por meio de experiências. (2) Desenvolve habilidades comunicativas que permitem utilizar a língua em contextos interculturais. (3) Permite conhecer regiões ou países vizinhos, e/ou grupos minoritários concretos. (4) Amplia o contexto cultural.

B. Ambiente: (1) Prepara para a internacionalização. O currículo pode ver-se influenciado em grande parte pelas necessidades especificadas ou pelas oportunidades que estejam presentes em determinando entorno imediato. (2) Prepara para obter títulos internacionais. Prepara os alunos para participar de experiências profissionais, ou para trabalhos futuros nos quais necessitam dominar várias línguas. (3) Melhora o perfil da escola. Segundo os autores (p. 231), os sistemas educativos começam a receber pressões para adaptar-se às novas demandas socioeconômicas da sociedade. Ao buscar atender a essas demandas, o perfil da própria escola é enriquecido.

C. Língua: (1) Melhora a competência linguística geral na língua alvo. O programa fomenta a integração das habilidades linguísticas. No entanto, os autores afirmam que, apesar do objetivo ser uma competência global de língua, não está descartada a ideia de trabalhar uma habilidade mais do que outras. O CLIL "permite conseguir uma integração satisfatória de língua e de conteúdos" (p. 226). (2) Desenvolve habilidades que contam na comunicação oral. (3) Sensibiliza tanto a língua materna como a L-alvo. (4) Desenvolve interesses e atividades plurilíngues. (5) Introduz uma nova L-alvo. 
D. Conteúdo: (1) Diversifica as perspectivas com que se estudam os conteúdos. (2) Apresenta terminologia temática específica na L-alvo. (3) Prepara para estudos posteriores e para a vida profissional.

E. Aprendizagem: (1) Desenvolve as estratégias individuais de aprendizagem. (2) Diversifica as práticas didáticas. (3) Aumenta a motivação do aluno.

Apesar de ser um programa para a integração da comunidade europeia, no qual o contexto é por vezes multilíngue, bilíngue, transacional, pluricultural, multicultural, consideramos que muitas das características podem ser ressignificadas para o nosso contexto (multicultural e globalizado).

Além das dimensões acima descritas e apresentadas na literatura, são mencionados por Do Coyle (2006) quatro elementos imprescindíveis para a organização e configuração de uma unidade didática de CLIL. Esses elementos são chamados de 4Cs (figura 10) e fazem referência à relação intrínseca entre conteúdo, comunicação, cognição e cultura. E todos esses elementos relacionados ao contexto, ou seja, ao atendimento das demandas do entorno, características locais. O conteúdo faz referência ao curricular ou tema do cotidiano; a comunicação ao ensino e aprendizagem da língua(gem) e o uso da língua(gem) para aprender; a cognição ao processo de aprendizagem, estratégias, mobilização do conhecimento, autoavaliação; a cultura à compreensão intercultural e alteridade.

\section{Figura 10 - The 4Cs framework for CLIL}

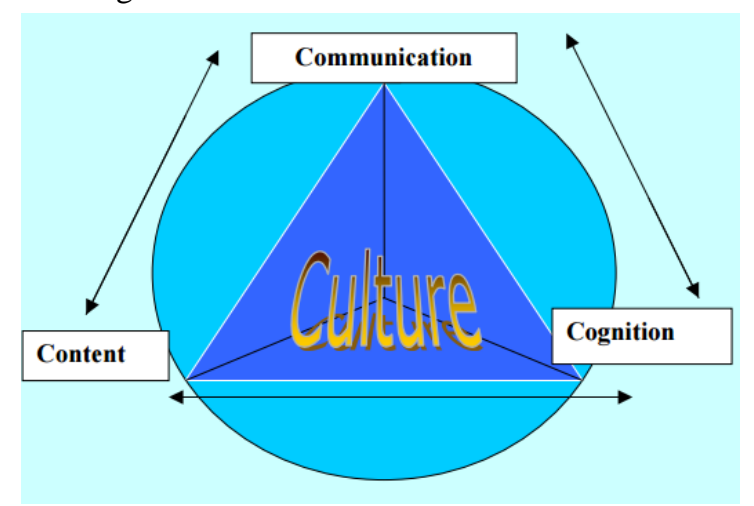

Fonte: Do Coyle (2006, p. 10)

Para o autor (op.cit, p.10), nos 4Cs, "a linguagem e a comunicação são usadas de forma intercambiáveis, como uma estratégia para promover a genuína comunicação em língua estrangeira, para além da sala de aula". Por este motivo, no CLIL, a aprendizagem de LE não ocorre em nível de progressão gramatical, deixando os tempos passados e construções 
linguísticas mais complexas para "mais tarde". Alunos que estudam sobre a sustentabilidade, por exemplo, precisam expressar-se no futuro, enquanto os que estudam a revolução industrial precisam usar tempos verbais do passado. Além disso, alunos do CLIL podem precisar da língua(gem) para discutir, debater, justificar e explicar.

Mehisto, Marsh e Frigols (2008) apresentam, ainda, características centrais do planejamento CLIL.

\section{Foco múltiplo/simultâneo/dual}

$\checkmark$ Apoia o ensino da língua por meio de conteúdo e o ensino do conteúdo por meio das línguas.

$\checkmark$ Integra disciplinas do currículo.

$\checkmark$ Organiza o ensino por temas e projetos interdisciplinares.

$\checkmark$ Apoia a reflexão sobre o processo de aprendizagem.

\section{Ambiente de aprendizagem seguro e enriquecedor}

$\checkmark$ Utiliza atividades e discursos do dia a dia.

$\checkmark$ Mostra a língua e o conteúdo em sala.

$\checkmark$ Constrói a confiança do aluno para experimentar com a língua e o conteúdo.

$\checkmark$ Guia o acesso aos ambientes e aos materiais autênticos.

\section{Autenticidade}

$\checkmark$ Permite aos alunos que solicitem ajuda com a língua que necessitam.

$\checkmark$ Maximiza a inclusão dos interesses dos alunos.

$\checkmark$ Estabelece relações de maneira regular entre a aprendizagem e a vida do aluno.

$\checkmark$ Estabelece relações com outros falantes, empregando materiais atuais dos meios de comunicação e de outras fontes.

\section{Efeito da aprendizagem}

$\checkmark$ Faz que o aluno comunique mais que o professor.

$\checkmark$ Atende às necessidades dos alunos; é o aluno que ajuda a estabelecer o conteúdo, língua e as habilidades de aprendizagem.

$\checkmark$ Fomenta a responsabilidade dos alunos, fazendo com que eles avaliem o progresso e o grau de alcance dos resultados de aprendizagem.

$\checkmark$ Favorece a aprendizagem cooperativa entre os colegas.

$\checkmark$ Negocia o significado da linguagem e o conteúdo com outros alunos. 
$\checkmark$ Favorece a atuação do professor como facilitador.

\section{Andaime}

$\checkmark$ Parte do conhecimento, das habilidades, das atitudes, dos interesses e das experiências prévias do aluno.

$\checkmark$ Divide a informação em formatos "amigáveis" para o aluno.

$\checkmark$ Responde aos diferentes estilos de aprendizagem.

$\checkmark$ Fomenta o pensamento crítico e criativo.

$\checkmark$ Desafia o aluno a dar novos passos e a se arriscar.

\section{Cooperação}

$\checkmark$ Planeja cursos/aulas/temas em comparação com o professor de conteúdo ou não.

$\checkmark$ Envolve os pais para aprender sobre CLIL e sobre como apoiar o aluno.

$\checkmark$ Envolve a comunidade local, autoridades e empregadores.

Entendemos que muitas dessas características supõem benefícios para a aprendizagem do aluno. Além da característica dual e simultânea que apresenta esse tipo de planejamento, outros aspectos do processo de ensino e aprendizagem, característicos da própria abordagem comunicativa, são apresentados como promovedores da aprendizagem significativa e relevantes para o aluno. Os autores (op. cit.) trazem questões que envolvem o papel do professor e do aluno nesse processo, destacando a importância do ambiente seguro e enriquecedor para a construção da confiança do aprendente. Questões sobre o uso de materiais autênticos e sua relação com a realidade dos alunos, a responsabilidade dos alunos com a sua própria aprendizagem e, portanto, o fomento da autoavaliação, negociação do significado, interação, participação ativa, o atendimento as suas necessidades e interesses; cooperação entre alunos, professores e terceiros, entre outras questões.

Vários desses aspectos têm sido discutidos na literatura da área em uma relação direta com a motivação, maior engajamento dos alunos no processo, autonomia e consequentemente aprendizagem satisfatória.

Quanto à motivação, concordamos com Cardoso (2002, p. 50) quando este afirma que o papel da motivação se revela como fundamental no processo de ensinar. Para o autor, a sala de aula tem de ser um ambiente prazeroso, onde o aluno "se envolve na dinâmica de negociação que possibilite ao aprendiz a instrumentalização de suas intenções comunicativas através da nova língua que a cada dia se desenvolve mais”. Dalmás (2009) afirma que a motivação 
favorece o envolvimento participativo dos alunos e que motivar é mobilizar. Mobilizar, para Vasconcellos (2000, p. 52), "implica (em) uma ação educativa no sentido de provocar, desafiar, estimular, ajudar o sujeito a estabelecer uma relação com o objeto".

Para a aprendizagem satisfatória, Miccoli (2010, p. 156) defende que a postura do professor é a de fomentar a autoavaliação dos alunos:

convidar os alunos a avaliarem a si mesmos, os colegas, o próprio professor e as aulas, de maneira construtiva e respeitosa, é uma forma de tornar a avaliação um procedimento para o aprimoramento de cada um, individualmente, contribuindo para um grupo mais coeso e aulas mais eficientes.

Para que os alunos sejam capazes de se tornar avaliadores do seu trabalho, eles devem ter metas claras; oportunidade de criar uma definição de qualidade do trabalho (que significa envolver os alunos na definição dos critérios, padrões de avaliação); feedback, a oportunidade de autocorreção ou autoajuste (BRUCE, 2006).

O CLIL ressalta, ainda, a importância do professor em conhecer os estilos de aprendizagem dos alunos (e dos alunos reconhecem os seus próprios estilos), para poderem mobilizar estratégias de aprendizagem que melhor se adaptem a sua maneira de aprender. Estilos de aprendizagem são características e preferências que cada indivíduo tem ao tentar adquirir e guardar informação. Para Brown (2007), são características gerais de funcionamento intelectual que variam entre as pessoas. Já as estratégias são definidas como maneiras específicas de abordar um problema, modos de operação para se alcançar um fim particular.

Em uma sala de aula, concorrem vários estilos de aprender e formas variadas de resolver questões e atividades apresentadas para todo o grupo. Neste sentido, é importante mobilizar a cooperação em grupo de forma a fomentar diferentes perspectivas de resoluções para uma mesma temática. Para referir-se à cooperação entre pares por meio da interação, o planejamento CLIL traz o termo andaimes (scaffolding $\left.{ }^{31}\right)$. Moura Filho $(2012$, p. 10) atribui à aprendizagem cooperativa um meio de promoção à "ajuda mútua entre alunos/alunos e professores/alunos, durante processos de sociabilização e de aquisição de habilidades acadêmicas". Para o autor, o desafio da aprendizagem cooperativa está na dificuldade do professor em selecionar "tarefas estimulantes, exequíveis e relevantes", ou ainda, tarefas

que favorecem a motivação necessária ao engajamento em atividades coletivas de ensino-aprendizagem e asseguram que um trabalho construtivo e produtivo será realizado tanto por apenas um aprendiz quanto por todo o seu grupo" (p. 13).

\footnotetext{
${ }^{31}$ Conceito originalmente usado por Wood, Bruner e Ross (1976).
} 
Algumas tarefas em um planejamento CLIL que podem ser estimulantes e relevantes têm uma relação direta com o uso de materiais autênticos, que, segundo (LEFFA, 1998, p. 2021), não se restringem aos livros ou artigos de revista, mas abrangem todas as formas de impressos, tais como

jornais (notícias, manchetes, fotos com legendas, propagandas, anúncios classificados, etc.), cartas, formulários, contas, catálogos, rótulos, cardápios, cartazes, instruções, mapas, programas, bilhetes, contratos, cartões, listas telefônicas, tudo enfim ao que o falante nativo está exposto diariamente.

Para o autor (op. cit.), o uso de textos simplificados deve ser evitado, porque prejudica a autenticidade do material; simplificar a tarefa é possível, se necessário for, mas não se deve simplificar a língua.

Em um curso ELFE, para Barçante ${ }^{32}$ (2013), a autenticidade dos textos é um tema mais tranquilo, pois se é ensino por conteúdo, o conteúdo implica textos que correm socialmente na área. Desse modo, os alunos são levados a aprender por meio de uma relação direta com a autencidade, uma vez que esta "maximiza a inclusão dos interesses dos alunos; estabelece relações de maneira regular entre a aprendizagem e a vida do aluno; e estabelece relações com outros falantes, empregando materiais atuais dos meios de comunicação e de outras fontes" (MEHISTO, MARSH e FRIGOLS, 2008).

Algumas propostas de ELFE para o uso autêntico de textos e tarefas sociais para determinada área têm levantado o uso das Tecnologias da Informação e Comunicação (TICs) como possibilidade enriquecedora para a sala de aula (TARNOPOLSKY, 2009; DAMIÃO, 2011; AUGUSTO-NAVARRO, et al., 2012). Damião (op. cit.) desenvolve e acompanha um curso de inglês para fins específicos por meio de website.

Augusto-Navarro et al. (op. cit., 2012) relatam, também, experiências satisfatórias para ELFE por meio de recursos digitais (blogs, e-mails) e insumos com cenas de filmes, seriados e propagandas. O objetivo dos autores, ao trabalhar as TICs, foi o de despertar interesse, motivação e sensibilizar os alunos em formação inicial sobre a necessidade da L-alvo em ambiente acadêmico. Como resultado, os autores afirmam que "essa prática revelou-se fundamental para garantir envolvimento e disposição dos participantes em lidar com textos acadêmico-profissionais em $\mathrm{LI}^{33 "}$ (p. 51).

\footnotetext{
32 BARÇANTE, Magali - Notas de Aula da Disciplina Ensino de Línguas em Contexto Tecnológico. Brasília: Universidade de Brasília. Em 2. 2013.

${ }^{33}$ Língua inglesa.
} 
Tarnopolsky (op. cit.) apresenta uma proposta de ELFE (leitura de periódicos e artigos da área) para um grupo de alunos psicólogos em pré-serviço por meio de conteúdos da própria internet, uma vez que o conhecimento científico está em constante atualização e a internet acompanha esse movimento de uso na comunicação real. Ao comentar o texto do autor (op. cit.) em sala de aula (ambiente virtual), Barçante (2013) salienta que a proposta de ensino e aprendizagem fundamentada em conteúdos e o uso da internet dá vivacidade ao material e constante atualização.

As aulas mais eficientes para o CLIL têm, portanto, uma relação direta com o que é significativo e relevante para os alunos. E, para isso, "integra disciplinas do currículo e organiza o ensino por temas e projetos interdisciplinares" (MEHISTO, MARSH e FRIGOLS, 2008).

A proposta de se buscar em matérias escolares fontes potenciais de conteúdos para suplementar a aprendizagem de uma LE tem sido apresentada por Almeida Filho (1993, 2012, 2013) como um elemento potencializador para o processo de aquisição. O autor nos dá como exemplo o fato de empregar algum conteúdo de Geografia, entre outros, ao ensino de língua: “aprender o sistema ecológico da Amazônia via a língua-alvo que se está aprendendo e no andamento sistematizar essa L no que for necessário para facilitar ou solidificar o processo de aprender" (ALMEIDA FILHO, 2013, p. 77).

É relevante citarmos, na obra de Schmidt (1958) O Ensino Científico das Línguas Modernas, a presença de uma didática de línguas já preocupada com um ensino mais significativo, promovendo de forma simultânea conhecimentos da língua com os do conteúdo. Em seu plano de lições (p. 279), a autora afirma que "a preparação das aulas deve prever o aproveitamento de conhecimentos adquiridos em outras cadeiras - geografia, história, ciências, etc.", e que deve usar o interesse dos alunos para influenciar o planejamento das aulas; os assuntos da atualidade; os insumos para fazer surgir o assunto da aula (SCHMIDT, op. cit., p. 278). Na descrição de um plano de aula para a quarta série, em leitura, a autora introduz o tema se reportando ao conhecimento e sentimento dos alunos sobre aquele tema e não somente se restringindo à aprendizagem do vocabulário (SCHMIDT, op. cit., p. 292). Ela ainda ressalta que o professor deve concentrar a atenção do aluno no assunto a ser estudado e diz como fazêlo: apresentar uma imagem, fazer uma pergunta-problema em que a aula será a solução deste problema, contar uma história ou anedota como ponto de partida, reportar-se a algum fato da ordem do dia, de um material, selo, por exemplo, fazendo surgir o assunto.

Além dos conteúdos do próprio currículo, vários autores, entre eles Almeida Filho (1989, 2012); Brinton, Snow e Wesche (1989); Bizón (1992, 1994); Xavier (1999); Brinton (2007); Barbirato (2008); Gottheim (2012) e Barbirato e Cassoli (2013), têm discutido a 
relevância de se ensinar língua por temas (do cotidiano). Um conjunto de tópicos correlacionados pode gerar um tema. Sendo assim, os temas são amplos e os tópicos são divisões subordinadas a eles, que se organizam em uma unidade, por exemplo: o tema violência se divide em tópicos como violência urbana, violência contra a mulher, violência rural, violência contra a criança, violência infantil, etc. (ALMEIDA FILHO, 2012).

Para Xavier (op. cit.) é relevante propor um menu de temas e tópicos por meio do qual os alunos podem escolher o conteúdo a partir de seus interesses e preferências, e acrescenta que encorajá-los em escolhas temáticas é uma forma de fazer com que eles deem sentido e significado ao que aprendem. A autora sugere combinar o planejamento por temas com a realização de tarefas comunicativas, que nomeia de Programa Temático Baseado em Tarefas (PTBT).

Para Marsh (2000, p. 2-3), “aprendizagem bem sucedida de língua pode ser bem alcançada quando as pessoas têm a oportunidade de receber instrução e ao mesmo tempo vivenciar situações da vida real, nas quais elas podem adquirir a língua". Neste trabalho, as situações da vida real foram vivenciadas por meio de tarefas, uma vez que, nessa pesquisa, elas buscam atender ao contexto de comunicação autêntico ao utilizado em situações que os alunos atuarão profissionalmente e em situações comunicativas cotidianas. As tarefas são, portanto, recortes da prática social de uso da LE pelo aluno, transportados didaticamente para a sala de aula.

O uso de tarefas foi impulsionado por Prabhu (1987), o qual efetuou, de 1979 a 1984, um projeto de desenvolvimento de tarefas na sala de aula para o ensino de inglês, com crianças de uma escola pública em Bangalore, na Índia. O projeto em questão foi o pioneiro no desenvolvimento e utilização de tarefas em sala de aulas.

A partir do final da década de 1980, outras pesquisas têm considerado a tarefa como construto teórico ou como unidade promotora de aquisição de línguas. Entre esses pesquisadores, podemos citar Nunan (1989), Skehan (1992), Scaramucci (1996), Willis (1996), Xavier (1999) e Barbirato (1999, 2005, 2008). Paralelamente às pesquisas sobre ensino por tarefas, intensificaram-se várias interpretações para esse termo.

Nunan (op. cit.) define tarefa como um trabalho de sala de aula que envolve os alunos na compreensão, manipulação, produção ou interação na L-alvo e destaca o foco da tarefa para o significado, ao invés da forma. Skehan (op. cit.), por sua vez, salienta que o sucesso na realização de uma tarefa é avaliado em termos de alcançar um objetivo

Encontramos também definições de tarefas entre pesquisadores brasileiros. Xavier (op. cit., p. 34), tomando como base definições trazidas por Candlin (1987), busca ressignificar o 
termo tarefa de modo que as "atividades com foco no significado possam coexistir com aquelas com foco na forma sem conflito de princípios”. Para isso, apresenta uma definição com base nas dimensões pragmática e cognitiva:

\footnotetext{
Tarefa é uma atividade que requer o envolvimento do aluno com o insumo oral e/ou escrito na língua-alvo, podendo ser ele de natureza gramatical ou não gramatical, com a finalidade de promover a compreensão, expressão e/ou negociação de significados nessa língua, conscientização gramatical e/ou raciocínio para que, então, o aluno possa chegar a um produto final (XAVIER, 1999 p. 34).
}

Xavier defende que tarefa é um tipo de atividade comunicativa a qual tem sempre um objetivo a ser alcançado pelo aprendiz (um produto final), por exemplo, encontrar uma solução para um quebra-cabeça, ler um mapa e dar direções, e ler um conjunto de instruções e montar um brinquedo. Em Willis (1996), encontramos o lidar de diferentes formas com informações, experiências, problemas, como listar informações; ordená-las/organizá-las; buscar semelhanças e diferenças entre elas (associação); resolver problemas; trocar experiências pessoais; e ainda tarefas de usar a criatividade para a construção conjunta de dramatizações, projetos, etc. Entendemos que esse último tipo de tarefa pode compreender uma ou mais tarefas.

Diante disso, consideramos que a tarefa possui um propósito comunicativo, especificando usos semelhantes àqueles que se têm na vida real (SCARAMUCCI, 1996; SKEHAN, 1996; BARBIRATO, 2005). Scaramucci (op. cit.) nos dá, como exemplo, o fato do aluno assistir a um vídeo e ser capaz de se posicionar com relação ao assunto apresentado, escrever uma carta solicitando informações, deixar um recado, etc. As tarefas, nessa perspectiva, "valoriza $(\mathrm{m})$ o sentido, com atividades mais significativas para o aluno e que têm relação com as situações prováveis de ocorrerem fora da sala de aula" (BARBIRATO, 2005, p. $3)$.

Encontramos o uso de tarefas no exame do Certificado de Proficiência em Língua Portuguesa para Estrangeiros (Celpe-Bras). No Manual do Exame (2011, p. 11), tarefa é defina como:

\footnotetext{
Um convite para interagir com o mundo, usando a linguagem com um propósito social, em outras palavras uma tarefa envolve basicamente uma ação, com um propósito, direcionada a um ou mais interlocutores. (MANUAL DO EXAMINADO, 2011).
}

Considerando as características apresentadas pelos autores acima, neste trabalho, tarefa é entendida como uma ação em sala de aula voltada para o significado, que tem um propósito semelhante aos das tarefas da vida real, um propósito comunicativo (convite para interação com 
o mundo), alcance de um produto final. Para o nosso estudo, o produto final requer o engajamento dos alunos em uma interação "metacomunicativa, através de atividades voltadas para o significado, ou metalinguística através de atividades voltadas para a gramática contextualizada e reflexiva" (XAVIER, 1999, p. 34). Percebe-se, então, que, para os alunos alcançarem produto final, precisarão de outros tipos de tarefas, as comunicativas e as possibilitadoras (ESTAIRE e ZANÓN, 1990; ESTAIRE 1990, 1999, 2000; ZANÓN e ESTAIRE, 2010), que poderão ser consideradas atividades. Esses dois autores distinguem três tipos de tarefas: tarefa final, tarefa comunicativa e tarefa possibilitadora.

Uma tarefa final implica todos os alunos na compreensão, produção ou interação na Lalvo, cuja atenção está mais no significado que na forma; tem uma estrutura com um princípio, um fim e um procedimento de trabalho claro, um objetivo, um tema e um resultado; seu desenvolvimento e finalização podem ser avaliados pelo professor e alunos e reproduzem situações da vida cotidiana. As tarefas comunicativas têm o foco no significado, devem reproduzir situações da vida cotidiana, enquanto as possibilitadoras atuam como suporte para as comunicativas e seu objetivo é o de propiciar aos alunos os instrumentos linguísticos necessários para realizar as tarefas comunicativas, quer dizer, possibilitam linguisticamente (ESTAIRE, 1990; ZANÓN e ESTAIRE, 2010; VILLARINO, 2010).

\subsubsection{Unidades temáticas no planejamento CLIL por tarefas}

Estaire (2010, p.7) apresenta procedimentos (passos) para determinar as tarefas centrais. O primeiro passo é o procedimento de análise de necessidades/interesses dos alunos, identificando usos e aplicações da LE e temas relacionados com seu universo. A autora esclarece que, no caso de ELFE, os interesses passam também a ser necessidades.

Passo 1. NECESSIDADES/INTERESSES ${ }^{34}$ : análise de necessidades dos alunos (em cursos ELFE) ou interesses (em cursos gerais).

Passo 2. USOS: Possíveis usos / aplicações da LE apropriados para cada nível e idade em relação com:

2a. Contexto: onde os alunos terão ou poderão atuar: pessoal, público, profissional e educativo (MCER) (MCER)

2b. Ações: que os alunos terão/poderão ter que realizar dentro desses contextos

Passo 3. TAREFAS

Passo 4. CONTEÚDOS

\footnotetext{
${ }^{34}$ Para o nosso curso estamos considerando as necessidades/interesses, por entendermos que os interesses podem ser também elementos motivacionais.
} 
A unidade didática será, portanto, um conjunto de tarefas comunicativas e de apoio linguísticos (possibilitadoras), determinadas para a tarefa final. Assim, cada tarefa (comunicativa e possibilitadora) tem como "objetivo alimentar e facilitar a realização das tarefas que as seguem especialmente a tarefa final" (ESTAIRE, 2010, p. 10).

Para tanto, Estaire e Zanón (1990) e Estaire (1990, 2010) apresentam procedimentos para a organização do processo (unidade didática) em 6 passos:

(1) definição do tema e da tarefa final (TF);

(2) especificação de objetivos a partir da TF em termos de capacidades (usar verbos de ação);

(3) especificação de conteúdos a partir da TF, em termos de saberes que são objetivos de ensino e aprendizagem;

(4) planejamento da sequência de tarefas comunicativas (TC) e possibilitadoras, de apoio linguístico (TAL) que conduzem à TF;

(5) ajustes dos passos anteriores (incluindo a possibilidade de ampliar ou reduzir a TF, os objetivos ou os conteúdos);

(6) planejamento da avaliação (critérios, procedimentos e instrumentos).

Os seis passos descritos anteriormente para o processo de elaboração de unidades didáticas são resumidos no esquema a seguir:

Figura 11 - Procedimento para a programação de unidades didáticas

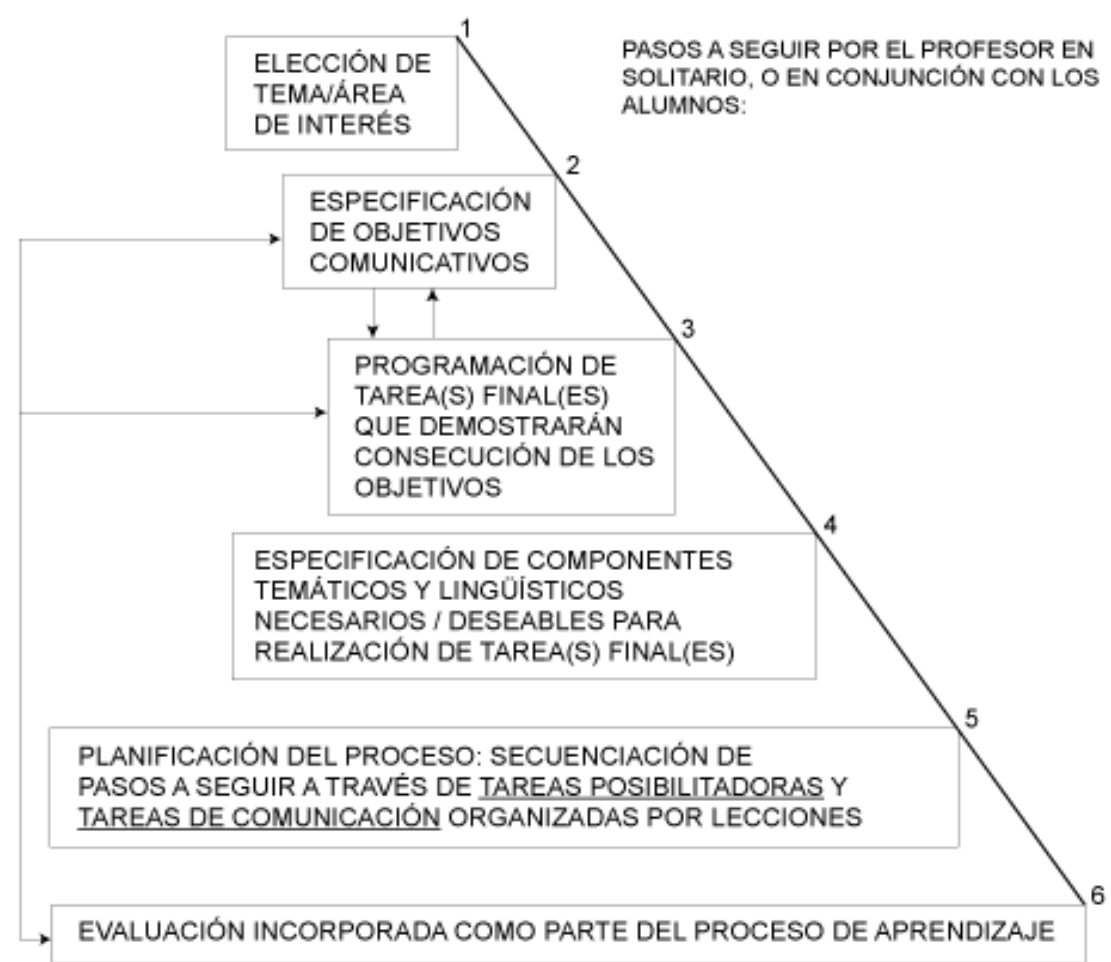

Fonte: Zanón e Estaire (1990 p. 412). 
No Brasil, Almeida Filho (2012, p. 51) apresenta "um esquema processual básico de organização das unidades":

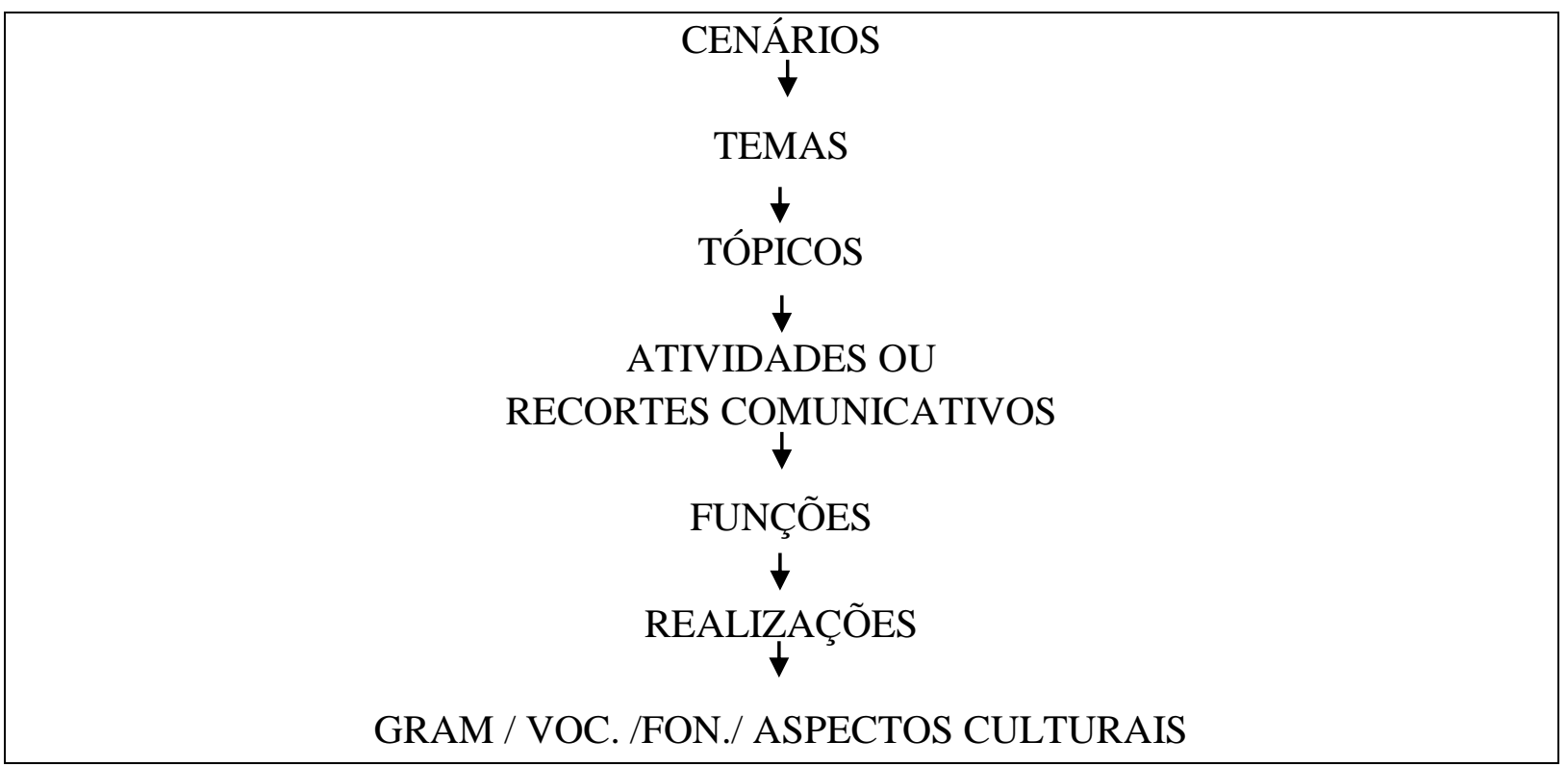

Neste trabalho, as tarefas são geradas a partir dos recortes comunicativos, que são, para Almeida Filho (1989), atividades socialmente reconhecíveis e que integram habilidades. Sendo assim, um recorte comunicativo corresponde a uma situação de uso social com várias ações (eventos comunicativos) a ela integradas, e, por isso pode ser, também, chamado de prática social na e para a L-alvo. As funções comunicativas, materialização dos expoentes linguísticos, emergem como apoio para a realização das ações, que determinam o conjunto de elementos linguísticos (gramática, vocabulário, fonética, aspectos culturais). Os elementos linguísticos podem ser explicitados nas tarefas possibilitadoras ou aparecer segundo as necessidades dos alunos nas interações para a tarefa final.

Para Villarino (op. cit.), a especificação dos componentes temáticos e linguísticos se divide em duas partes: aspectos concretos do tema ou área de interesse; e conteúdos linguísticos (nocional-funcional, gramatical, lexical e fonológico). Os conteúdos linguísticos ocupam um papel secundário, mas não deixam de ter sua relevância no processo de comunicação e na capacitação dos alunos no alcance dos objetivos de comunicação (ALMEIDA FILHO, 1993).

Para atender aos novos objetivos contemporâneos para a comunicação, na medida em que novos comportamentos e ações aparecem, quando, no contexto, as TICs se tornam presentes Tarefas de manipulação de informações na internet, por parte dos alunos, podem ser definidas utilizando a taxonomia de Bloom, publicada em 1950 e atualizada por Churches (2009). Churches (op. cit.), ao trazer a taxonomia para a era digital, busca atender aos cenários 
educativos e diferentes aspectos que o professor pode desenvolver nas aulas, por meio das TICs, conforme ilustra a imagem a seguir:

Figura 12 - Mapa da taxonomia digital de Bloom

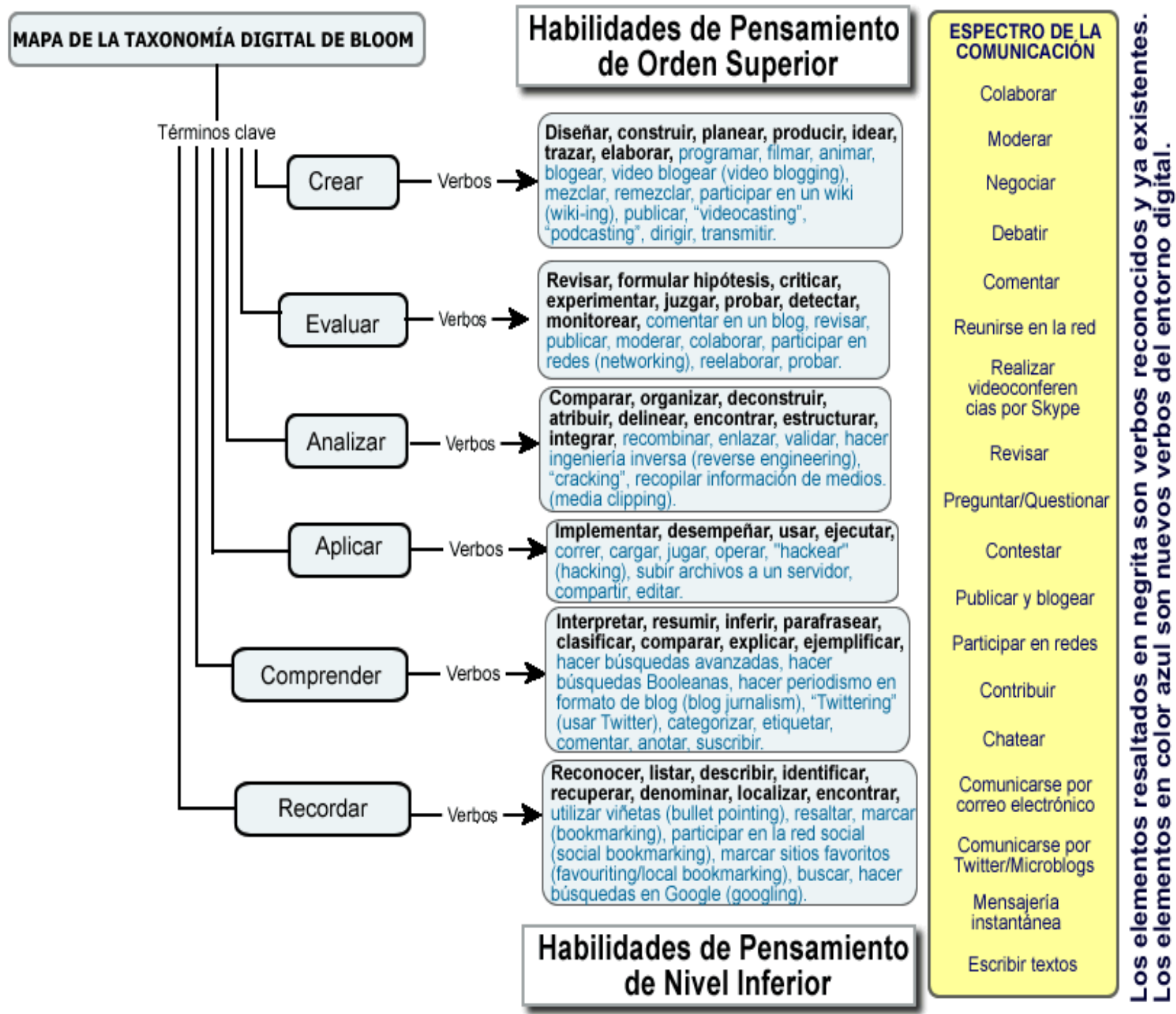

Fonte: Churches (2009, p.3) http://www.eduteka.org/TaxonomiaBloomDigital.php.

Um planejamento CLIL por tarefas, dadas as características a seguir descritas (quadro 2), pode atender a um curso para fins gerais e para fins específicos. 
Quadro 2 - Características do planejamento CLIL por tarefas

\begin{tabular}{|c|c|}
\hline \multicolumn{2}{|c|}{ CLIL por tarefas } \\
\hline \multicolumn{2}{|c|}{$\begin{array}{l}\text { 1. Ensino dual e simultâneo (conteúdos/temas e língua) } \\
\text { (DO COYLE, 2006; VERDUGO, 2011, MARSH, 2000, MARSH, MALJERS e } \\
\text { HARTIALA, 2001; MEHISTO, MARSH e FRIGOLS, 2008) }\end{array}$} \\
\hline $\begin{array}{l}\text { A. Relevantes e de interesse para o } \\
\text { aprendiz. (ALMEIDA FILHO, 1993,2013, } \\
\text { BRINTON, 2007; BRINTON, SNOW e } \\
\text { WESCHE,1989; MEHISTO, MARSH e } \\
\text { FRIGOLS, 2008) e ligação entre escola e } \\
\text { mundo (GOTTHEIM ,2013 }{ }^{35} \text { ). } \\
\text { B. Utilizáveis, apresentando certa novidade } \\
\text { para a maioria dos alunos (BRINTON, } \\
\text { SNOW e WESCHE, 1989). } \\
\text { C. Educacionalmente construtivos e } \\
\text { conflitivos (ALMEIDA FILHO, 2013). } \\
\text { Desenvolver atitudes humanas } \\
\text { (GOTTHEIM, 2013). } \\
\text { D. Do próprio currículo (ALMEIDA } \\
\text { FILHO, 2013; MEHISTO, MARSH e } \\
\text { FRIGOLS, 2008) }\end{array}$ & $\begin{array}{l}\text { Integração de habilidades (SCARCELLA e } \\
\text { OXFORD, 1992; BRINTON, 2007; } \\
\text { GOTTHEIM, 2013; BRINTON, SNOW e } \\
\text { WESCHE, 1989; MARSH, MALJERS e } \\
\text { HARTIALA, 2001). } \\
\text { Foco no sentido ao invés da forma } \\
\text { A. A atenção à forma é secundária } \\
\text { (BRINTON, 2007; BARBIRATO, 2008; } \\
\text { NUNAN,1989; XAVIER, 1999). } \\
\text { B. O uso da forma não é descartado. } \\
\text { (ALMEIDA FILHO, 2013) } \\
\text { C. Subordinados (BRINTON, SNOW e } \\
\text { WESCHE, 1989). } \\
D . \quad \text { De forma contextualizada (BRINTON, } \\
\text { SNOW e WESCHE, 1989) } \\
\text { E. De forma clara chamar a atenção de forma } \\
\text { (BRINTON, 2007). }\end{array}$ \\
\hline \multicolumn{2}{|c|}{$\begin{array}{l}\text { 2. Tarefas } \\
\text { m aquelas que se tem na vida real. } \\
\text { 996; SCARAMUCCI, 1996; BARBIRATO, 2005; } \\
\text {, MARSH e FRIGOLS, 2008) }\end{array}$} \\
\hline $\begin{array}{l}\text { Interação, negociação de significados } \\
\text { GOTTHEIM ,2013; MEHISTO, MARSH e } \\
\text { Autenticidade/Materiais autênticos (BRII } \\
\text { 2008) } \\
\text { Direcionando para os interesses dos alun }\end{array}$ & $\begin{array}{l}\text { ambiente colaborativo. (XAVIER, 1999; } \\
\text { FRIGOLS, 2008). } \\
\text { TON, 2007; MEHISTO, MARSH e FRIGOLS, } \\
\text { s (MEHISTO, MARSH e FRIGOLS, 2008) }\end{array}$ \\
\hline
\end{tabular}

Ao propormos neste trabalho o planejamento para o ELFE na EPT integrando conteúdos/temas e língua por tarefas, nos valemos dos objetivos dos alunos (necessidades/interesses) de um curso técnico de nível médio subsequente e das necessidades da situação-alvo (eixo gestão e negócio, área de Logística) para organização do curso. Delimitar conteúdos/temas e tarefas faz parte do ato de planejar do professor nessa pesquisa-ação e os procedimentos para a sua estruturação estão descritos no capítulo que segue

\footnotetext{
${ }^{35}$ Gottheim (2013, p.58) apresenta alguns princípios na organização de um material didático “A gente Brasileira”, baseado em conteúdos temáticos para um projeto de investigação de ambientes comunicativos com o uso de um material que fosse informativo e que problematizasse questões sociais. Optamos por incluir os pressupostos da organização da aprendizagem em um programa de ensino por conteúdo feito pela autora, por considerar que eles podem também ser utilizados na organização de qualquer unidade temática.
} 


\title{
CAPÍTULO 3 - METODOLOGIA
}

\author{
Palavras articuladas com sujeitos e um contexto
}

Para produzir e organizar os planos e os procedimentos de uma pesquisa, segundo Creswell (2010), devemos atentar para alguns elementos imprescindíveis, como a escolha do tipo de projeto e as suposições filosóficas que guiam o estudo, as estratégias de investigação, a coleta e análise dos dados.

De modo parecido, Flick (2009) discute alguns itens relevantes para uma pesquisa, por exemplo, uma postura teórica e métodos de coleta de dados e de interpretação. Com base nos autores, podemos inferir que a estrutura de uma pesquisa é definida em, pelo menos, cinco dimensões ${ }^{36}$. Dentro de cada dimensão trazida por FLICK (op. cit.) e CRESWELL (op. cit.), selecionamos as propostas que melhor se identificaram ao nosso projeto de pesquisa.

Para Creswell (op. cit., p. 25), “a seleção de um projeto de pesquisa é também baseada na natureza do problema ou na questão que está sendo tratada, nas experiências pessoais dos pesquisadores e no público ao qual o estudo se dirige”. Sendo assim, optamos pela seguinte seleção, ilustrada no quadro a seguir (quadro 3), considerando os nossos objetivos e sua natureza:

- o processo de ensino e aprendizagem de uma língua estrangeira na EPT, com a elaboração de um planejamento de curso nesse contexto com a participação ativa do pesquisador e dos atores e sua avaliação a partir das percepções dos alunos participantes; e, por fim, as nossas interpretações.

\footnotetext{
36 As 5 dimensões trazidas por Creswell, são apresentadas na literatura por variadas nomenclaturas que representam (na nossa interpretação) ideias semelhantes, podendo, portanto, ser usadas como sinônimos. Por exemplo:

1. Tipo de projeto: ou tipo de pesquisa/investigação, abordagem. A pesquisa pode ser qualitativa, quantitativa ou mista (CRESWELL, 2010).

2. Suposições filosóficas: ou posição epistemológica, paradigmas, postura teórica, perspectivas filosóficas, paradigmas filosóficos. Que pode ser para Creswell (2010) pós-positivista, construtivista/interpretativista, reivindicatória e pragmatista, e, para Flick (2009), interacionismo simbólico, fenomenologia, etnometodologia, construtivismo, psicanálise e estruturalismo genético.

3. Estratégias de investigação: ou procedimentos de investigação, método*, que pode ser, para Creswell (2010): Pesquisa narrativa, Fenomenologia, Etnografias, Estudos de Teoria Fundamentada e Estudo de caso.

4. Técnicas de coleta dados: ou instrumentos de coleta de dados. Para Creswell (2010) e Flick (2009), entrevistas documentos, observação entre outros.

5. Análise dos dados: ou interpretação dos dados, modo de análise. Para Creswell (2010), codificação, categorização (descrição/tema), e, para Flick (2009), codificação teórica, análise de conteúdo, análise narrativa, métodos hermenêuticos, análise de conversação, discursos, gêneros, documentos.

* o método engloba a coleta, análise e interpretação (CRESWELL, 2010).
} 
Quadro 3 - Escolhas metodológicas

Tipo de projeto: qualitativa (GIBBS, 2009; FLICK, 2009; CRESWELL, 2010).

Posição Epistemológica: interpretativista (CRESWELL, 2010).

Estratégia de investigação/Método: pesquisa-ação (THIOLLENT, 2012; EL ANDALOUSSI, 2004).

Técnicas de coletas de dados: levantamento bibliográfico e documental (GIL, 2010) questionários (VIEIRA-ABRAHÃO, 2006; NUNAN, 1992), entrevistas semiestruturadas (ROSA e ARNOLDI, 2006), diário do aluno (BARBIER, 2007).

Análise de dados: Codificação e Categorização (CRESWELL, 2010; GIBBS, 2009); Triangulação (GIBBS, 2009).

Fonte: Elaborado pela autora

Isso posto, descrevemos, detalhadamente, as nossas escolhas metodológicas para cada uma das cinco dimensões que compõem nossa pesquisa.

\subsection{TIPO DE PESQUISA E POSIÇÃO EPISTEMOLÓGICA}

\subsubsection{Qualitativa-interpretativista}

A pesquisa qualitativa visa, segundo Gibbs (2009), abordar o mundo "lá fora", esmiunçar a forma como as pessoas constroem o mundo a sua volta, entender, descrever e, às vezes, explicar os fenômenos sociais de maneiras diferentes. Para tanto, examina e investiga, observa, registra experiências, interações e documentos. Todas essas formas de abordar uma situação podem ser reconstituídas e analisadas de diferentes formas, permitindo ao pesquisador "desenvolver modelos, teorias e tipologias a fim de explicar as questões sociais e psicológicas" (p. 9).

Creswell (2010) apresenta algumas características da pesquisa qualitativa, e, entre elas, destacamos duas: o caráter interpretativo desse tipo de pesquisa e a análise indutiva dos dados. Para o autor, a pesquisa qualitativa é "uma forma de investigação interpretativa em que os pesquisadores fazem uma interpretação do que enxergam, ouvem ou entendem (p. 209)" e, para isso, criam seus próprios padrões, categorias e temas, organizando os dados em unidades de informação de forma indutiva. Para Gibbs (op. cit., p. 20), "grande parte da pesquisa qualitativa tenta explicitamente gerar novas teorias e novas explicações. Nesse sentido, a lógica subjacente a ela é indutiva".

$\mathrm{O}$ uso de abordagem qualitativa oferece procedimentos para que o pesquisador possa estudar um fenômeno "conhecido", analisando-o sob outra ótica, ou até mesmo utilizando-o 
para construir uma teoria fundamentada sobre um fenômeno em particular (CRESWELL, op. cit.).

No caso da nossa pesquisa, ao buscarmos entender o processo de ensino e aprendizagem de LE (“de que forma", “como") - por meio de uma construção empírica com a elaboração de um planejamento de curso e sua avaliação (descrevendo e interpretando as percepções e os discursos/textos das partes envolvidas) -, foi possível produzir interpretações e novas hipóteses.

A pesquisa qualitativa, ao tratar de estudos das relações sociais "dentro da nova diversidade de ambientes, subculturas, estilos e formas de vida (...), exige uma nova sensibilidade para o estudo empírico das questões" (FLICK, 2009, p. 20). Para o autor as mudanças sociais e essa pluralização motivam os pesquisadores a enfrentar novos contextos. Buscamos conhecer, em nossa pesquisa, outras práticas sociais de uso real da língua, além da sala de aula, levando em consideração essa variedade, diversidade de contextos e perspectivas sociais discutidas por Flick (op. cit.), o que nos permitiu a natureza aplicada de nossa área, a Linguística Aplicada (LA), cujo objeto é o problema real de linguagem dentro ou fora do contexto escolar (ALMEIDA FILHO, 2009).

Isso considerado, passamos à próxima dimensão, articulando pesquisa e ação aos sujeitos e ao contexto.

\subsection{MÉTODO: PESQUISA-AÇÃO}

A pesquisa-ação pode ser concebida como "um caminho de procedimentos para interligar conhecimento e ação, ou extrair da ação novos conhecimentos" (THIOLLENT, 2012, p. 8). Para o autor (2012), a pesquisa-ação é voltada para a descrição de situações concretas e para a intervenção ou a ação orientada em função da resolução de problemas. Ao relacionar a teoria e os discursos que acompanham o desenrolar da pesquisa, estabelece novas argumentações e conclusões, sendo, portanto, de base empírica.

El Andaloussi (2004), citando as contribuições de Kurt Lewin, percursor da pesquisaação, apresenta quatro possiblidades para a sua aplicação: a ação pesquisa diagnóstica, a participante, a empírica e a experimental. Quanto à ação empírica, com a qual se identifica esta pesquisa, resulta em documentar experiências de um grupo e tirar conclusões. Para o autor, "a pesquisa é a ação pela qual o pesquisador produz conhecimentos” (p. 85). Sendo assim, o estilo de uma pesquisa-ação é determinado pelo tipo de ação e nível de participação do pesquisador, 
podendo ser: (1) operação programada pelos pesquisadores; (2), situação espontânea e natural; e (3) conjunto de operações planejadas em comum entre pesquisadores e atores.

No primeiro estilo, o pesquisador elabora instrumentos, vai a campo para observar uma situação "natural" e recolher informações, participando como especialista (foco na pesquisa); no segundo, o pesquisador tem uma participação mais ativa (foco na ação); e, no terceiro, adota com os atores uma dada problemática, tendo em vista a sua melhoria (foco na pesquisa e na ação). Considerando os três estilos, o importante é observar que numa pesquisa-ação "os interessados tornam-se atores e, participando do desenvolvimento da ação, contribuem para produzir novo saberes" (p. 89).

Em nossa pesquisa, a estratégia de pesquisa-ação nos permitiu investigar o nosso objeto de estudo de forma mais detalhada. Levando em consideração as acepções de pesquisa-ação comentadas anteriormente, optamos, nesta pesquisa, por uma ação-operação programada pelo pesquisador (1), e um conjunto de operações planejadas em comum entre pesquisadores e atores (3), tendo, portanto, o foco na pesquisa e na ação.

Ao propormos o nosso estudo com o foco na pesquisa e na ação, objetivamos uma compreensão atual da EPT local, no que concerne o processo de ensino e aprendizagem de uma LE. No caso de nossa pesquisa, os estilos (1) e (3) propostos por El Andaloussi (2004) se fundem, tendo um conjunto de operações planejadas (planejamento do curso) em comum entre pesquisadores e atores (alunos e situação-alvo) e operação planejada pelo pesquisador na aplicação e avaliação desse planejamento.

Percebemos assim, que a pesquisa-ação procura unir a pesquisa à ação, descrevendo, interpretando as situações reais e desenvolvendo o conhecimento como parte de uma práxis, seja de forma mais ativa seja de forma menos ativa (formulando hipóteses e instrumentos). É, portanto, uma maneira de se fazer pesquisa com objetivo de melhor compreender a nossa prática, e também progredir no campo das teorizações por meio de (observ)ações e reflexões.

\subsection{O CONTEXTO E SEUS PARTICIPANTES}

Por se tratar de uma pesquisa-ação, os participantes inseridos no contexto estudado devem ser descritos. Fazem parte do contexto desta pesquisa a Rede Federal de Educação Profissional e Tecnológica e os Institutos Federais (IFs), o Catálogo Nacional de Cursos Técnicos, o curso de Logística do Instituto Federal de Brasília (IFB), em que o planejamento 
aqui proposto foi implementado, e o planejamento de curso do componente LE elaborado e implementado nesse (Instituto Federal) IF.

Os participantes da pesquisa são os alunos do IFB, onde o planejamento foi implementado, a professora-pesquisadora e profissionais da área de Logística. Iniciaremos essa parte pela descrição dos participantes/atores e, em seguida, discorreremos sobre o contexto no qual estão inseridos.

Ainda nesta seção, apresentaremos a estrutura do planejamento.

\subsubsection{Participantes}

\subsubsection{Alunos do curso técnico em Logística}

A turma selecionada para a pesquisa é a de técnico subsequente em Logística, do IFB, do $2^{\circ}$ semestre de 2014. A turma é composta por alunos falantes nativos de língua portuguesa, oriundos, em sua maioria, de escolas públicas, nas quais concluíram o Ensino Médio (EM).

A idade predominante do grupo $(85,7 \%)$ é daquela em que os jovens e adultos estão inseridos no mercado de trabalho, ou tentando nele entrar (entre 18 a 35 anos). A amostra total foi de 28 alunos para o levantamento inicial sobre o perfil do grupo e os dados foram apresentados em porcentagem. A maioria trabalha $(89,2 \%)$ e a metade dos alunos (50\%) afirma já ter tido algum tipo de contato com a língua espanhola anteriormente, na escola ou por meio de músicas, filmes, etc. Entretanto, são poucos os que possuem conhecimento prévio na L-alvo.

A participação dos alunos, para essa pesquisa, foi de extrema importância, uma vez que o planejamento foi direcionado para o grupo e avaliado por eles mesmos. Assim, suas percepções escritas em diários e apresentadas em questionário final de autoavaliação (QFA) foram de grande relevância para responder as nossas perguntas de pesquisa.

Para a análise dos diários, consideramos apenas (5) alunos, pois foram os que compareceram em todos os encontros e registraram as aulas em seguida, outros (3) alunos entregaram os diários após a realização da análise, e, desta forma, não foram considerados. Os demais alunos não entregaram seus diários. Quanto ao questionário de autoavaliação, dos (25) alunos que finalizaram o curso, (21) o responderam.

$\mathrm{Na}$ análise dos diários consideramos os seguintes aspectos para a sua identificação: 
Quadro 4- Identificação das aulas e dos alunos

\begin{tabular}{|c|c|}
\hline $\begin{array}{c}\text { Aulas } \\
(\mathbf{1 0} \text { AULAS })\end{array}$ & Aa1, Aa2, Aa3, Aa4, Aa5, Aa6, Aa7, Aa8, Aa9, Aa10 \\
\hline $\begin{array}{c}\text { Alunos } \\
\text { (05 ALUNOS) }\end{array}$ & A1, A2, A3, A4, A5 \\
\hline $\begin{array}{c}\text { Resposta dos alunos ao questionário } \\
\text { final de autoavaliação }\end{array}$ & QFA \\
\hline
\end{tabular}

\subsubsection{A professora-pesquisadora}

A professora, e também pesquisadora deste trabalho, tem formação em Letras-Espanhol e é especialista em Ensino-Aprendizagem de Línguas pela Universidade de León - Espanha (2009). Desde 2010, é professora de língua espanhola do ensino básico, técnico, tecnológico do IFB. É supervisora de curso do Programa Nacional de Acesso ao Ensino Técnico e Emprego (PRONATEC).

A pesquisadora ainda participa do grupo de pesquisa Educação e Trabalho do IFB desde 2013 e, atualmente, coordena projetos de pesquisa sobre o processo de ensino e aprendizagem de LE no contexto da EPT, tendo como integrantes alunos bolsistas do Conselho Nacional de Desenvolvimento Científico e Tecnológico $(\mathrm{CNPq})$, pertencentes ao programa de iniciação científica (PIBIC-EM) do IFB. Com o objetivo de entender melhor o papel da LE nos cursos da EPT, e também suas particularidades e especificardes quando ensinada nesse contexto, esse grupo pretende mapear as necessidades de uso de LE para diferentes eixos tecnológicos e áreas de EPT, bem como para diferentes níveis e modalidades de ensino.

\subsubsection{Profissionais da área de Logística}

A seleção dos profissionais de Logística foi feita por meio de amostragem de conveniência e não probabilística (LAVILLE e DIONNE, 2007; CRESWELL, 2010; FLICK, 2009), uma vez que esta é mais acessível por ser baseada na acessibilidade, conveniência e disponibilidade da população.

As empresas foram identificadas em resposta à busca na internet pelos termos “empresas de Logística”, "Logística e Transporte”, conjugados com a opção por estado (Distrito Federal) e ou cidade (Brasília). Com os dados gerados, elaboramos uma lista com o contato de 34 empresas (nome da empresa, ramo e e-mail). Entretanto, após a consulta minuciosa aos 
dados disponíveis, foi possível verificar que apenas 24 empresas mantinham no cadastro o seu contato eletrônico.

De um total de 24 e-mails enviados em julho de 2013, obtivemos resposta apenas de uma empresa. Reenviamos os e-mails e aguardamos as respostas por mais 15 dias. Como não a obtivemos, realizamos o contato por telefone.

O questionário (apêndice E) enviado as empresas da área de Logística constava com 13 questões, sendo 03 de identificação dos respondentes (fechadas) e 10 de tema ( 7 fechadas e 3 abertas). As questões voltadas à identificação dos participantes e/ou de temas (abertas) levaram em consideração os seguintes aspectos:

$\checkmark$ Empresa onde trabalha, ramo da atividade e cargo que atua na empresa;

$\checkmark$ Descrição das principais tarefas desempenhadas no dia a dia do trabalho (recorte);

$\checkmark$ Se a LE é utilizada em algumas dessas tarefas e em quais cargos;

$\checkmark$ Importância que o profissional atribui ao conhecimento de uma LE para a área.

Foram realizadas, ainda, perguntas fechadas com o intuito de confirmar ações dentro do recorte que os profissionais descreveriam sobre as tarefas que desempenham no dia a dia. Essas perguntas foram assim direcionadas para levantamento de informações quanto ao uso das habilidades de ler, escrever, ouvir e falar na LE no ambiente de trabalho. A sua frequência de uso, com qual público é utilizada a LE e de que forma (pessoalmente, por e-mail, face a face). Para cada uma dessas ações, foi feito o detalhamento das atividades mais usuais.

Como obtivemos apenas uma resposta do questionário, mesmo após contato telefônico, decidimos visitar pessoalmente algumas empresas (com a autorização prévia e agendada) e realizar entrevistas semiestruturadas, com o objetivo de conhecer melhor a rotina desses profissionais de Logística e promover uma situação mais amigável.

Ao buscar essa forma de contato, a nossa amostragem passou a ser de apenas 15 empresas, com o número sendo reduzido, pois, ao buscar agendar nossas visitas às empresas, muitas não se sentiram confortáveis, acreditando ser pesquisa "de mercado" de possíveis empresas concorrentes. Dessa forma, a nossa população foi definida como: 15 empresas da área de Logística, localizadas no Distrito Federal, as quais visitamos entre agosto de 2013 a outubro de 2013. 


\subsubsection{Contexto}

\subsubsection{Rede Federal de Educação Profissional e Tecnológica e os Institutos Federais}

Foi na Lei de Diretrizes e Bases da Educação Nacional (LDB) - nº 9.394, de 20 de dezembro de 1996, que o termo "Educação Profissional" foi utilizado pela primeira vez, em um capítulo especial dedicado a ela, separado da Educação Básica: Capítulo III, artigos 39 a 42. Em 2008, pela redação dada pela Lei no 11.741, o termo passou a ser "Educação Profissional e Tecnológica" (EPT), substituindo as várias "expressões que tentam, através da história, imprimir significado à educação profissional: ensino profissional, formação profissional ou técnico profissional, educação industrial ou técnico-industrial, qualificação, requalificação e capacitação" (BRASIL, 2004).

Como parte do programa de expansão da EPT do governo brasileiro, por meio da Lei ${ }^{\circ}$ 11.892, de 29 de dezembro de 2008, instituiu-se a Rede Federal de Educação Profissional, Científica e Tecnológica.

Embora a Rede Federal de EPT tenha sido estabelecida em 2008, em Lei, “a formação profissional como responsabilidade do Estado inicia-se no Brasil em 1909, com a criação de 19 escolas de artes e ofícios" KUENZER (2009, p. 27). Conforme ilustrado no quadro a seguir.

Quadro 5 - Evolução da Educação Profissional no Brasil

\begin{tabular}{|c|c|}
\hline 1909 & $\begin{array}{l}\text { Nilo Peçanha iniciou, no } 19 \text { Escolas de Aprendizes Artífices } \\
\text { Brasil, o ensino técnico por } \\
\text { meio do Decreto } \mathrm{n}^{\circ} 787 \text { de } 11 \\
\text { de setembro de } 1906\end{array}$ \\
\hline 1931 & $\begin{array}{l}\begin{array}{l}\text { Reforma política de Francisco } \\
\text { Campos por meio de decretos }\end{array} \\
\begin{array}{l}\text { organiamenta a organização do ensino secundário e } \\
\text { técnicas de comércio }\end{array} \\
\end{array}$ \\
\hline 1942 & $\begin{array}{l}\text { Institui as Leis Orgânicas Nacional da Educação do } \\
\text { Ensino Secundário e do Ensino Industrial. São criadas } \\
\text { entidades especializadas, como o Serviço Nacional de } \\
\text { Aprendizagem Industrial (SENAI) }\end{array}$ \\
\hline 1943 & \begin{tabular}{|lll|lllll} 
Lei Orgânica do Ensino & Criação do Serviço & Nacional de & Aprendizagem \\
Comercial & (Decreto-Lei & $n^{\circ}$ & Comercial (SENAC) & & & \\
$6.141 / 43)$ & & & & & & & \\
\end{tabular} \\
\hline 1946 & $\begin{array}{l}\text { Lei Orgânica do Ensino Primário (Decreto-Lei n } \\
\text { 8.529/46), do Ensino Normal (Decreto-Lei } \mathrm{n}^{\circ} \text { 8.530/46) e } \\
\text { do Ensino Agrícola (Decreto-Lei } \mathrm{n}^{\circ} \text { 9.613/46) }\end{array}$ \\
\hline 1961 & $\begin{array}{l}\text { Os estabelecimentos de ensino industrial recebem a } \\
\text { denominação de Escolas Técnicas Federais }\end{array}$ \\
\hline
\end{tabular}




\begin{tabular}{|c|c|}
\hline 971 & $\begin{array}{l}\text { Lei Federal } \mathrm{n}^{\circ} 5.692 / 71 \text {, que } \\
\text { reformula a Lei Federal } \mathrm{n}^{\circ} \\
4.024 / 61\end{array}$ \\
\hline 1978 & \begin{tabular}{|l|l|} 
Lei no 6.545 & $\begin{array}{l}\text { Transforma a Escola Técnica Federal de Minas Gerais, } \\
\text { Paraná e do Rio de Janeiro nos três primeiros Centros } \\
\text { Federais de Educação Tecnológica (CEFETs) }\end{array}$ \\
\end{tabular} \\
\hline 994 & \begin{tabular}{|l|l|} 
Lei Federal nº 8.948/94 & Cria o Sistema Nacional de Educação Tecnológica \\
\end{tabular} \\
\hline 1996 & 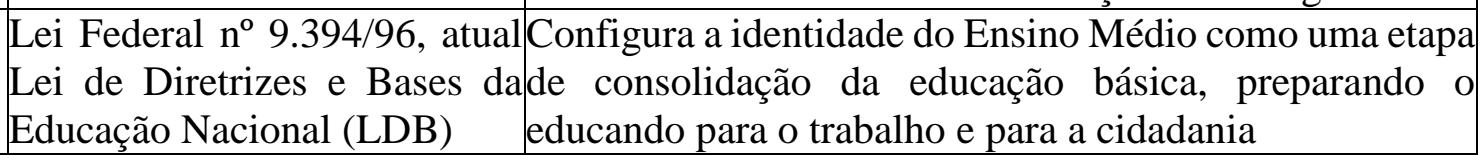 \\
\hline 1997 & \begin{tabular}{|l|l|} 
Decreto $n^{0} 2.208 / 97$ & $\begin{array}{l}\text { Regulamenta a educação profissional e a separa do } \\
\text { Ensino Médio. Criação do Programa de Expansão da } \\
\text { Educação Profissional (PROEP) }\end{array}$
\end{tabular} \\
\hline 1999 & $\begin{array}{l}\text { No período mais recente, entre } 1999 \text { e } 2004 \text {, as mudanças } \\
\text { legislacionais foram: o censo da educação superior } \\
\text { registrava } 16 \text { instituições de educação superior } \\
\text { tecnológica, todas públicas; em 2004, para } 144 \\
\text { instituições }\end{array}$ \\
\hline 2003 & $\begin{array}{l}\text { A antiga Semtec/MEC, hoje intitulada Setec, inicia um } \\
\text { processo de debates com a sociedade, visando ao } \\
\text { aperfeiçoamento da legislação da educação profissional e } \\
\text { tecnológica }\end{array}$ \\
\hline 2004 & \begin{tabular}{|l|l}
$\begin{array}{l}\text { Decreto 5154/2004, 5224 e } \\
\text { 5225/2004 }\end{array}$ & $\begin{array}{l}\text { Retorno da possibilidade de integração da EP e Educação } \\
\text { Geral. Reacendeu discussões sobre a politecnia }\end{array}$
\end{tabular} \\
\hline 2008 & $\begin{array}{l}\text { Institui a Rede Federal de Educação Profissional, } \\
\text { Científica e Tecnológica e os Institutos Federais }\end{array}$ \\
\hline
\end{tabular}

Fonte: Quadro resumo elaborado pela autora a partir das informações sobre o percurso da EPT no site do MEC (http://portal.mec.gov.br) e em KUENZER (2009).

Segundo o Ministério da Educação (MEC), atualmente, são 562 escolas técnicas em atividade, conforme representado na figura a seguir.

Figura 13- Cenário da expansão da EPT desde 2002 até 2014

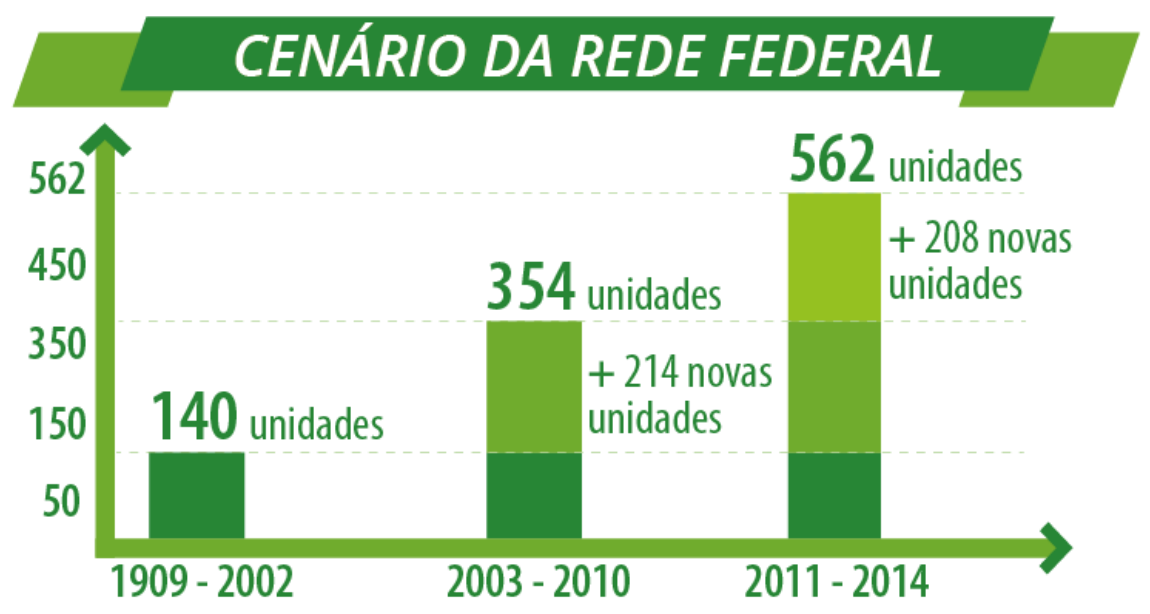

Fonte: http://redefederal.mec.gov.br/expansão-da-rede-federal 
Os Institutos Federais (IFs) fazem parte da gama de opções de EPT da Rede Federal que se tem hoje no Brasil (atualmente são 38 unidades), assim como a Universidade Tecnológica Federal do Paraná - UTFPR; Centros Federais de Educação Tecnológica Celso Suckow da Fonseca - CEFET-RJ e de Minas Gerais - CEFET-MG; Escolas Técnicas Vinculadas às Universidades Federais; Colégio Pedro II ${ }^{37}$ (BRASIL, 2008, 2012)

A Lei $n^{\circ}$ 11.892/2008 define os IFs como instituições de educação superior, básica e profissional, pluricurriculares e multicampi, especializadas na oferta de educação profissional e tecnológica nas diferentes modalidades de ensino (BRASIL, 2008). Por isso, os IFs têm ofertado a EPT em todos os seus níveis de escolaridade e modalidades de ensino, desde o nível básico, com cursos de Formação inicial e continuada de trabalhadores (FICs), ao superior com cursos de pós- graduação stricto sensu.

Além disso, os IFs apoiam políticas públicas de oferta de EPT presencial e à distância, como o Programa Nacional de Acesso ao Ensino Técnico e Emprego (Pronatec), lançado em 2011; e o sistema Rede e-Tec Brasil, lançado em 2007, que tem como objetivo ampliar, interiorizar e democratizar o acesso a cursos Técnicos de Nível Médio e FICs, e programas como o Profuncionário, Mulheres Mil e Rede Certific.

Segundo informações contidas no site do MEC, o Profuncionário possibilita a formação dos funcionários de escolas técnicas, em efetivo exercício (BRASIL, 2008); o Certific, por sua vez, permite o reconhecimento dos saberes dos trabalhadores adquiridos ao longo de sua vida profissional (BRASIL, 2008); enquanto o Programa Mulheres Mil oferta cursos de EPT para mulheres em situação de vulnerabilidade social (BRASIL, 2009).

\subsubsection{O Catálogo Nacional de Cursos Técnicos, o Eixo Gestão e Negócios e o Curso Técnico de Nível Médio (Subsequente) em Logística}

Decidimos agrupar os três contextos acima, por estarem estreitamente relacionados, o que ajudará o leitor a acompanhar a construção do texto. Este trabalho adotou, como contexto, o curso técnico de nível médio subsequente em Logística do Instituto Federal de Brasília (IFB), que faz parte do eixo Gestão e Negócios.

O eixo Gestão e Negócios, objeto do nosso estudo, é caracterizado pelas tecnologias organizacionais, viabilidade econômica, técnicas de comercialização, ferramentas de

\footnotetext{
${ }^{37}$ Incluído pela Lei n ${ }^{\circ} 12.677$, de 2012.
} 
informática, estratégias de marketing, Logística, finanças, relações interpessoais, legislação e ética, e conta com 17 cursos. O curso de Logística é uma das opções dentro desse eixo tecnológico, podendo ser integrado, concomitante ou subsequente.

De acordo com o projeto político-pedagógico do IFB, as atribuições do técnico em Logística seriam, principalmente, operacionalizar processos de aquisição, administração de materiais; dar suporte às decisões quanto à seleção de fornecedores, compra de materiais locais ou internacionais; dimensionar processos de armazenagem; conhecer os processos de distribuição de produtos; auxiliar na sistematização de processos de transportes, com base em conhecimentos e habilidades sobre modais, composição de custos de frete e de negociação.

Conforme dados do MEC (2011/2012), os cursos de Logística são oferecidos em 991 unidades no Brasil, incluindo técnico e tecnólogos, escolas da rede pública e privada, tanto de forma presencial quanto à distância, com um total aproximado de 90.466 alunos matriculados.

Só nos IFs, há a oferta de cursos técnicos e tecnólogos em Logística em 22 unidades. Entre eles, seis oferecem língua estrangeira (apêndice D).

\subsubsection{O componente curricular LE no curso técnico em Logística e o cronograma do curso}

O curso técnico em Logística do IFB é ofertado desde 2011, com duração de um ano e meio, ou seja, em três módulos semestrais. O componente curricular LE é ofertado no segundo módulo e tem uma carga horária de 40 horas/aula neste curso, distribuída em 2 horas/aula semanais. Vale ressaltar que, no final dessa pesquisa, o curso passou por uma reformulação, passando a ser de 1 ano e a LE retirada da grade curricular.

O curso foi elaborado com base no modelo de planejamento proposto por Almeida Filho (2012) e Estaire e Zanón (1990). Apresentamos o cronograma das aulas, datas de suas aplicações, temas/tópicos e a carga horária $(\mathrm{CH})$ destinada a cada temática, no quadro a seguir:

Quadro 6 - Cronograma das aulas

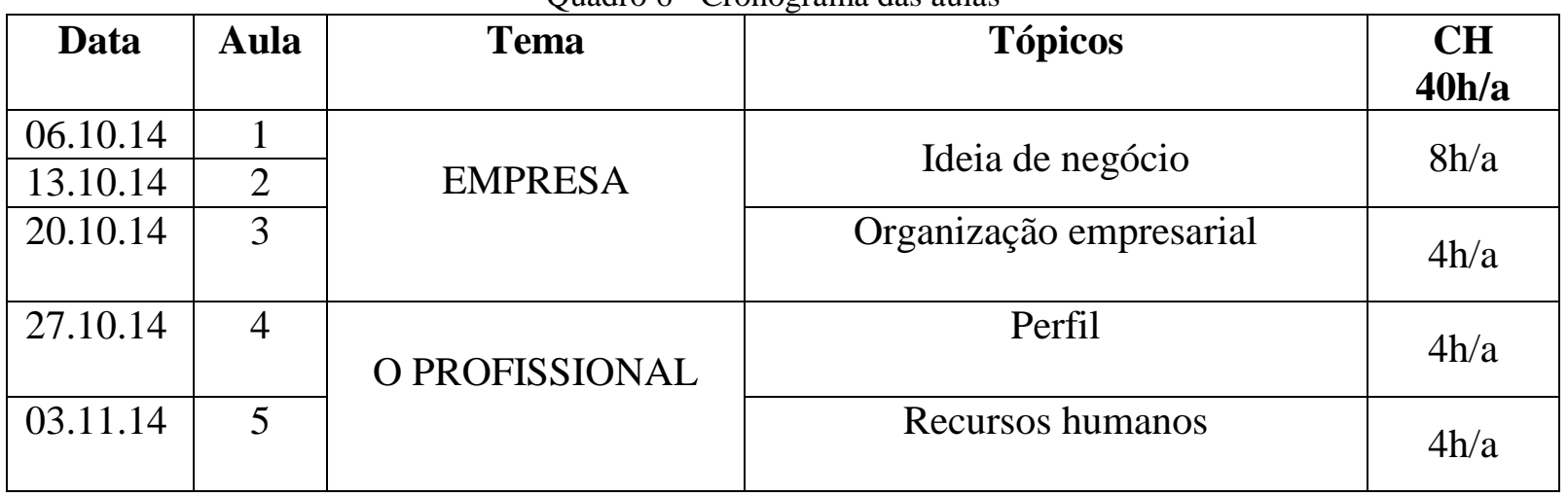




\begin{tabular}{|c|c|c|c|c|}
\hline 10.11 .14 & 6 & \multirow{2}{*}{ MERCADOS } & Produtos e serviços & $4 \mathrm{~h} / \mathrm{a}$ \\
\hline 17.11 .14 & 7 & & Mercadotecnia & $4 \mathrm{~h} / \mathrm{a}$ \\
\hline 24.11 .14 & 8 & \multirow{2}{*}{ COMUNICAÇÃO } & Cliente e fornecedores & $4 \mathrm{~h} / \mathrm{a}$ \\
\hline $\begin{array}{l}01.12 .14 \\
08.12 .14\end{array}$ & $\begin{array}{l}9 \\
10\end{array}$ & & $\begin{array}{c}\text { Documentos, Logística e } \\
\text { Transporte }\end{array}$ & $8 \mathrm{~h} / \mathrm{a}$ \\
\hline
\end{tabular}

Os demais componentes: os objetivos de cada unidade e as tarefas (final, comunicativas e possibilitadoras) serão apresentados no capítulo de análise de dados, na seção (4.1.3) destinada à descrição dos critérios utilizados em nosso planejamento CLIL por tarefas para o ELFE na EPT.

\subsection{TÉCNICAS DE COLETA DE DADOS}

Na pesquisa-ação, há o uso de várias técnicas no que se refere aos instrumentos de pesquisa, por exemplo, o diário, registros audiovisuais, análise de conteúdo; inclusive, segundo Barbier (2007), a pesquisa-ação utiliza os instrumentos comuns de pesquisa em Ciências Sociais, mas, também, adota ou cria outros.

No nosso estudo, procuramos diversificar os instrumentos de coleta, utilizando técnicas específicas da pesquisa-ação, tais como o "diário" (BARBIER, 2007) e ainda as técnicas de pesquisas clássicas, como entrevistas e questionários (FLICK, 2009), além do levantamento bibliográfico e documental (GIL, 2010).

Os nossos instrumentos foram selecionados com base em uma relação direta com os fins que se pretendem alcançar nesta pesquisa Sendo assim, apresentamos, de forma resumida, os nossos objetivos de pesquisa, instrumentos de coletas, participantes e os resultados que esperamos alcançar, no quadro a seguir: 
Quadro 7 - Objetivos da pesquisa e sua relação com instrumentos, participantes e procedimentos

\begin{tabular}{|c|c|c|c|}
\hline Objetivos & Instrumentos & $\begin{array}{c}\text { Objeto/ } \\
\text { Participantes }\end{array}$ & $\begin{array}{c}\text { Procedimentos/ } \\
\text { Resultados }\end{array}$ \\
\hline $\begin{array}{l}\text { Discutir } \\
\text { procedimentos de } \\
\text { elaboração de um } \\
\text { planejamento CLIL } \\
\text { por tarefas para o } \\
\text { ELFE na EPT } \\
\text { técnica de nível } \\
\text { médio subsequente. }\end{array}$ & $\begin{array}{l}\text { - Levantamento } \\
\text { bibliográfico e } \\
\text { documental. } \\
\text { - Questionários } \\
\text { para os alunos } \\
\text { do curso: perfil e } \\
\text { análise de } \\
\text { objetivos. } \\
\text { - Entrevistas. }\end{array}$ & $\begin{array}{l}\text { Literatura } \\
\text { Especializada. } \\
\text { Documentos da EPT } \\
\text { Ofertas de trabalho } \\
\text { Alunos e } \\
\text { profissionais da área. } \\
\text { (*professor- } \\
\text { pesquisador). }\end{array}$ & $\begin{array}{l}\text { Explorar e descrever a } \\
\text { sistematização de um } \\
\text { planejamento de curso para } \\
\text { o ensino de ELFE na EPT, } \\
\text { a partir da discussão sobre } \\
\text { as especificidades e as } \\
\text { particularidades das ações } \\
\text { pedagógicas para a } \\
\text { formação profissional, dos } \\
\text { objetivos dos alunos e da } \\
\text { situação-alvo. }\end{array}$ \\
\hline 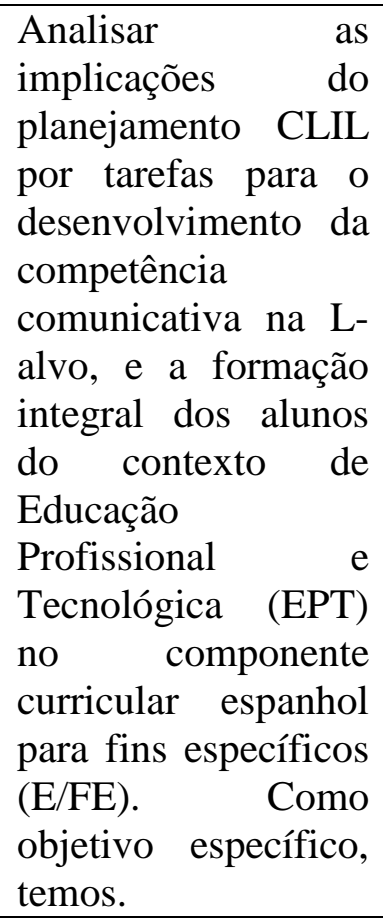 & $\begin{array}{l}- \text { Diário dos } \\
\text { alunos } \\
-\quad \text { Questionário } \\
\text { final de } \\
\text { autoavaliação } \\
\text { para os alunos. } \\
-\quad \text { Triangulação } \\
\text { das demais } \\
\text { fontes de dados. }\end{array}$ & $\begin{array}{l}\text { Alunos e professor- } \\
\text { pesquisador. } \\
\text { Documentos e a } \\
\text { literatura } \\
\text { especializada. } \\
\text { Planejamento } \\
\text { proposto }\end{array}$ & $\begin{array}{l}\text { Descrever e analisar o } \\
\text { processo de aprendizagem } \\
\text { mediado pelo uso do } \\
\text { planejamento elucidado, a } \\
\text { partir das percepções } \\
\text { descritas no diário pelos } \\
\text { alunos e questionário de } \\
\text { final de autoavaliação. } \\
\text { Interpretar os dados } \\
\text { codificados } \\
\text { categorizados por meio de } \\
\text { triangulação e construir } \\
\text { nossas interpretações, } \\
\text { reflexões e hipóteses. }\end{array}$ \\
\hline
\end{tabular}

* o professor-pesquisador, em todo o momento da pesquisa, é um participante. Ele tenta identificar, descrever padrões e temas a partir da(s) perspectiva(s) dos participantes, e, depois, tenta compreender, explicar esses padrões por meio de uma fundamentação teórica e levantar novas interpretações e visões.

Detalharemos, a seguir, cada instrumento utilizado.

\subsubsection{Levantamento bibliográfico}

É, no levantamento bibliográfico, que estarão as informações e dados necessários ao estudo (GIL, 2010). Para o autor, é importante delimitar as fontes capazes de fornecer as respostas adequadas ao desenvolvimento da pesquisa; e, para isso, cita algumas: livros, revistas, jornais, obras de referências, periódicos científicos, teses e dissertações, anais de encontros 
científicos, periódicos de indexação e resumo, que podem ser pesquisados em biblioteca convencional ou em base de dados.

O nosso levantamento bibliográfico, em teses e dissertações e em base de dados de portais de periódicos científicos eletrônicos (Ibict) e repositórios institucionais programas de Pós-Graduação de LA no Brasil, teve como objetivo preliminar:

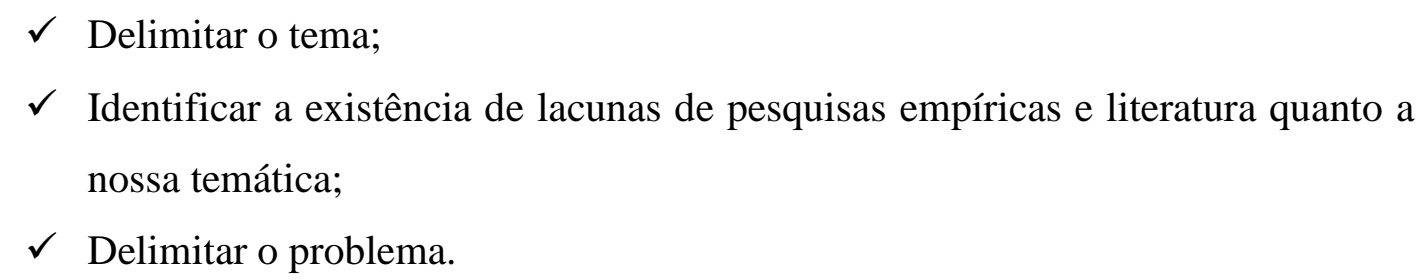

Consideramos, para isso, a busca pelas seguintes palavras-chave (no título): ensino instrumental de línguas; línguas para fins específicos; para propósitos específicos; inglês/espanhol técnico, tecnológico.

Além disso, com o objetivo de melhor alcançar nosso objeto de estudo e identificar na literatura elementos que pudessem guiar o nosso planejamento de curso, realizamos um levantamento bibliográfico também em livros, obras de referências, periódicos científicos em base de $\operatorname{dados}^{38}$, resultando numa revisão de literatura sobre o tema exposto e na delimitação do corpus desta pesquisa.

Para Creswell (2010, p. 52), a revisão da literatura pode ser encontrada em uma seção separada, estar incluída na introdução ou permear todo o estudo. Em nossa pesquisa, ela se encontra na introdução e durante todo este estudo, inclusive na seção de discussão dos dados. A revisão de literatura não guia nem direciona o estudo, mas se torna útil para a identificação de padrões e categorias, segundo o mesmo autor. Ela promove a identificação, localização e obtenção de documentos pertinentes ao estudo de um tema bem limitado, levantando-se a bibliografia básica (MACEDO, 1994).

Na introdução, a revisão de literatura nos ajudou a estruturar o problema. Uma vez que, por meio de um levantamento bibliográfico de teses e dissertações publicadas em nosso país sobre o ensino do ELFE (apêndice A), foi possível identificar a escassez de pesquisas quanto ao planejamento de curso para o ensino de ELFE na EPT.

\footnotetext{
${ }^{38}$ Portais de periódicos científicos eletrônicos: Portal de Periódicos da Capes e periódicos da área com avaliação prévia pelos pares: The ESPecialist: Pesquisa em Línguas para Fins Específicos. Descrição, Ensino e Aprendizagem. ISSN 2318-7115.
} 
Sendo assim, apesar da pesquisa bibliográfica ser considerada, também, um tipo de pesquisa elaborada com base em material já publicado, "praticamente toda pesquisa acadêmica requer em algum momento a realização de trabalho que pode ser caracterizado como pesquisa bibliográfica" (GIL, 2010). Sendo assim, ela é uma parte metodológica importante de toda pesquisa científica.

\subsubsection{Análise documental}

Segundo Gil (2010), qualquer elemento portador de dados pode ser considerado documento. Para o nosso estudo, realizamos levantamento documental na legislação pertinente da EPT, no catálogo nacional de cursos técnicos e em anúncios de oferta de trabalho, a fim de identificar informações relevantes para o nosso planejamento em um curso técnico de nível médio subsequente. Para tanto, foram analisadas as legislações gerais da EPT e as específicas para esse nível e modalidade de ensino.

A - Documentos Legais: legislação da EPT;

Quanto à legislação específica para o Ensino Técnico de Nível Médio, demos ênfase à análise das Diretrizes Curriculares Nacionais para a Educação Profissional de Nível Técnico $\mathrm{DCNEP}^{39}$, e, em ocasião, alguns dos documentos que a atualizam ou alteram algumas de suas informações.

\section{B - Catálogo Nacional de Cursos Técnico;}

Versão 2012 do Catálogo Nacional de Cursos Técnicos, que contempla 220 cursos, distribuídos em 13 eixos tecnológicos, e a Edição 2014/versão para a reunião do Comitê Nacional de Políticas de Educação Profissional Tecnológica. O objetivo foi o de identificar conteúdos/temas comuns entre os cursos técnicos do eixo tecnológico pesquisado.

C - Oferta pública de emprego.

Foi realizado um levantamento do que o mercado de trabalho, por meio das ofertas públicas de emprego, exige de profissionais técnicos do eixo Gestão e Negócios. Para isso,

\footnotetext{
${ }^{39}$ O Conselho Nacional de Educação instituiu as Diretrizes Curriculares Nacionais para a Educação Profissional de Nível Técnico - DCNEP (BRASIL,2012), por meio da Resolução CNE/CEB nº 04/99, fundamentada no Parecer CNE /CEB nº 16/99. E a Resolução nº 6, de 20 de setembro de 2012, define as Diretrizes Curriculares Nacionais para a Educação Profissional Técnica de nível médio
} 
foram analisadas, no período de julho a setembro de 2014, as ofertas de trabalho apresentadas em alguns sites de empresas especializadas em recolocação profissional: www.empregos.com.br, www.catho, www.injobs. Foram analisados apenas anúncios que mencionassem o nível técnico (concluído ou cursando).

\subsubsection{Questionários}

A aplicação de questionário se mostra como técnica eficiente para a coleta de dados, visto que gera informações concretas, o que confere precisão e clareza por conta de suas perguntas diretas; são flexíveis quanto a sua estruturação, podendo conter desde perguntas fechadas, itens de escalas ou questões abertas de acordo com os objetivos da pesquisa; e produzem dados fáceis de serem manipulados, a fim de mapear os elementos que constituem o objeto de pesquisa (VIEIRA-ABRAHÃO, 2006). Os questionários foram divididos em:

\subsubsection{Perfil e objetivos dos alunos.}

Para a obtenção de dados no levantamento do perfil do grupo de seus objetivos, o questionário tem sido um dos instrumentos mais frequentes (HUTCHINSON e WATERS, 1987). Para esta pesquisa, elaboramos dois questionários: um (fechado) que buscou traçar o perfil do grupo; e outro (semiaberto) que buscou identificar os seus objetivos (apêndice C). De acordo com Nunan (1992), nas questões fechadas, o pesquisador determina ou delimita as respostas por intermédio de opções ao respondente. Nas questões abertas, o respondente pode decidir o que quer dizer com mais liberdade. $\mathrm{O}$ autor salienta que, em um mesmo questionário, pode haver questões abertas e fechadas (questionário semiaberto). Este tipo de questionário foi a nossa opção para o levantamento de análise de objetivos.

O primeiro questionário (perfil do grupo) continha 11 questões fechadas versando sobre as seguintes temáticas:

\footnotetext{
$\checkmark$ Informações pessoais do aluno: idade, sexo e situação laboral;

$\checkmark$ A relação do aluno com as informações e/ou com o conhecimento produzido;

$\checkmark$ Interesse em cursar o curso técnico em Logística; e

$\checkmark$ Percepções quanto à formação profissional.
} 
O segundo questionário (semiaberto) de análise de objetivos dos alunos continha 12 questões (7 fechadas e 5 abertas) e buscou as seguintes informações:

$\checkmark$ Contato prévio com a língua espanhola;

$\checkmark$ Ocasiões de contato com a L-alvo;

$\checkmark$ Nível de conhecimento na língua espanhola;

$\checkmark$ Opinião sobre a importância da LE em curso técnico;

$\checkmark$ Necessidades e interesses (temas, formas de interação a serem trabalhadas em sala, competências a ser desenvolvidas); e

$\checkmark$ Motivação em relação ao curso.

O questionário foi aplicado dois meses antes do início das aulas, que ocorreu em 10 de outubro de 2014. A aula de Língua Espanhola é oferecida uma vez por semana, durante um semestre, dividida em 20 encontros de 2h/a. No entanto, para esta pesquisa, foram negociados com a coordenação do curso 10 encontros de 4h/a. Optamos por essa mudança, por considerar que muitas atividades trabalhadas em sala teriam uma sequência, e que, talvez, esse formato contribuísse para o processo de aprendizagem dos alunos.

\subsubsection{Final de autoavaliação}

O questionário de autoavaliação final para os aprendentes (apêndice F) teve por objetivo apresentar uma visão geral em relação ao curso e ao planejamento proposto, a partir das percepções (opiniões) dos alunos. O questionário teve, portanto, um caráter de instrumento de pesquisa ao fornecer dados que pudessem ser analisados (interpretados) pelo professorpesquisador e de instrumento de avaliação discente, uma vez que a autoavaliação (seja ela por questionário, ou por outros instrumentos) fomenta a reflexão do aluno em relação a sua própria aprendizagem. Esse instrumento ao fornecer dados a partir da análise e interpretação das respostas e do feedback dos alunos se torna um instrumento importante para (re)configuração de (outros) planejamentos de curso pelo professor-pesquisador.

Buscamos verificar, no questionário, a percepção dos alunos quanto ao desenvolvimento de competências durante o curso: de uso em LE (desempenho) e de competências gerais para a vida produtiva e social (ampliação de visão, leitura crítica do mundo, valores, atitudes, entre outras). 


\subsubsection{Entrevistas}

As entrevistas podem ser utilizadas tanto como ferramenta primária de fonte de dados quanto como fonte de dados secundária. São constituídas por perguntas que são realizadas na interação face a face e são classificadas em três tipos, de acordo com o nível de estruturação e o roteiro de questões utilizadas, são elas: estruturada, semiestruturada e livre (ROSA e ARNOLDI, 2006).

Na nossa pesquisa, utilizamos a entrevista semiestruturada, já que esta permite maior flexibilidade. Nesse tipo de entrevista, os entrevistados podem discorrer e verbalizar seus pensamentos, tendências e reflexões. Além disso, a sequência fica por conta do discurso dos sujeitos e da dinâmica que acontece naturalmente (ROSA e ARNOLDI, op. cit.).

As entrevistas foram realizadas com profissionais da área específica de Logística. Por meio desse instrumento, identificamos as tarefas desempenhadas por esses profissionais em sua rotina diária e no uso da LE. Para isso, nos guiamos por um roteiro composto de duas perguntas:

1. Você poderia descrever as suas atividades diárias dentro da empresa?

2. Na empresa em que trabalha, a língua estrangeira é utilizada? Em que situação? Por exemplo, para ler e responder e-mail, em reuniões, atender clientes, fornecedores. E de que forma? Por telefone, pessoalmente, internet, etc. Caso ela não seja utilizada poderia falar sua opinião sobre a importância de seu uso para o seu trabalho ou para a área em que trabalha (no caso a Logística)?

Entrevistamos um profissional de cada uma dessas empresas que pode nos receber, da área de Logística e/ou área afins. Por esse motivo, o cargo do profissional não foi o mesmo em todas as empresas, variando entre (1) líder de Logística, (1) coordenador, (1) supervisor operacional, (3) almoxarife, (4) encarregado/assistente/auxiliar de Logística, (3) conferentes e (2) do setor de compras.

Para a análise das respostas das entrevistas, identificamos as empresas e seus profissionais da seguinte forma:

Quadro 8- Identificação das empresas

\begin{tabular}{|c|l|}
\hline Empresas & E1 E2, E3, E4, E5, E6, E7, E8, E9, E10, E11, E12, E13, E14 e E15 \\
\hline $\begin{array}{c}\text { Profissionais das } \\
\text { Empresas }\end{array}$ & $\begin{array}{l}\text { PE1, PE2, PE3, PE4, PE5, PE6, PE7, PE8, PE9, PE10, PE11, PE12, } \\
\text { PE13, PE14, PE15 }\end{array}$ \\
\hline
\end{tabular}


Os profissionais da área de Logística, ao descrever recortes de sua rotina diária e o uso da comunicação, auxiliaram-nos no mapeamento de usos e necessidades requisitadas pela área de Logística em relação à LE.

\subsubsection{Diário dos alunos}

Para Barbier (2007), numa pesquisa-ação o diário é um instrumento para registro dos acontecimentos. Perante a natureza de nossa investigação, surgiu a necessidade de registar as percepções dos alunos durante a aplicação do planejamento. Foi solicitado, então, que, em cada encontro, os alunos realizassem uma autoavaliação/autorreflexão, fornecendo uma visão geral (de cada aula) sobre o que aprenderam e sobre o que precisavam melhorar, conforme explicitado no diário:

Prezado (a) aluno (a),

O objetivo maior no processo de ensino-aprendizagem de uma língua estrangeira (LE) deve ser, sobretudo, o de propiciar o desenvolvimento de uma competência de uso que nos sirva para circular socialmente na língua-alvo e isso quer dizer que buscamos adquirir uma competência comunicativa (CC) no novo idioma para acessar informações, conhecimentos, discutir, interpretar, negociar, opinar contribuindo, assim para a nossa participação social. Desse modo, esperamos que você relate nesse diário suas percepções em relação ao processo de ensino e aprendizagem da língua espanhola nesse curso. Para cada encontro tente realizar estas reflexões: quais foram às contribuições da aula de hoje para o desenvolvimento de competências na língua e de formação humana, traga reflexões sobre como e quais atividades possibilitaram tais desenvolvimentos. Avalie seu desempenho na aula de hoje: muito bom, bom, aceitável, ruim, muito ruim.

Entendemos que a autoavaliação, em cada encontro, pode proporcionar ao aluno ferramentas para aprimorar suas competências e também fortalecer convicções sobre as atividades que são capazes de desempenhar. E, para o professor, fornece ferramentas para outros planejamentos.

\subsection{PROCEDIMENTOS PARA A ANÁLISE DOS DADOS}

Para Creswell (2010), a análise e interpretação dos dados é um processo permanente durante a pesquisa, envolvendo a reflexão e anotações contínuas sobre os dados durante todo o estudo, podendo inclusive surgir, durante esse processo, questões analíticas. As questões analíticas visam a "orientar e ajudar a organizar a recolha dos dados à medida que a investigação vai decorrendo" (BOGDAN e BIKLEN, 1994, p. 208). 
Ainda segundo Creswell (2010), normalmente, a análise qualitativa básica consiste em analisar temas e perspectivas e relatar entre quatro e cinco temas, com possibilidade de ir além desse procedimento e utilizar mais de uma das estratégias de investigação qualitativa. Para o nosso estudo, utilizamos os passos sistemáticos da teoria fundamentada, dado que ela é também apontada como um modo de análise e não como um método de pesquisa (MYERS, 2015). Consideraremos, portanto, essa perspectiva, para o nosso estudo.

A teoria fundamentada, para Gibbs (2009), é uma das formas mais usadas para codificação, uma vez que tem como objetivo "gerar de forma indutiva ideias teóricas novas ou hipóteses a partir dos dados". Essas novas teorias, chamadas de fundamentadas, são, assim, relacionadas à teoria existente.

\subsubsection{Codificação e Categorização}

Para Gibbs (2009, p. 60), “a codificação é uma forma de indexar ou categorizar o texto para estabelecer uma estrutura de ideias temáticas em relação a ele". Por meio da codificação, podemos gerar "código, índice, categorias ou temas" e, logo, interpretá-los e extrair significados.

Seguindo os passos de análise da teoria fundamentada, podemos utilizar três tipos de codificação (STRAUSS e CORBIN, 2007 apud CRESWELL 2010; GIBBS, 2009): codificação aberta, axial e seletiva.

A codificação aberta gera categorias de informações, neste caso, o texto é lido de forma reflexiva com a finalidade de identificar as categorias relevantes. Podem ser construídos, também, vários contrastes para ajudar a entender o que pode estar por trás do texto. Na nossa pesquisa, a codificação buscou identificar as implicações do planejamento no processo de ensino e aprendizagem de ELFE na EPT, para isso surgiram perguntas analíticas que se confirmaram na codificação aberta, como identificar quais os potenciais e as limitações do planejamento proposto. Para Gibbs (2009), a codificação aberta pode analisar palavras, expressões ou sentenças. Ela pode ser feita, ainda, linha por linha, forçando o pensamento analítico a gerar códigos que reflitam as experiências dos participantes e não a nossa de pesquisador ou de alguma pressuposição teórica. Uma vez que, na codificação aberta, esse é apenas o primeiro passo, logo esta será refinada em uma codificação axial.

A codificação axial seleciona uma das categorias e a posiciona dentro de um modelo teórico. Nessa situação, as categorias são refinadas, desenvolvidas e relacionadas ou 
interconectadas; enquanto a codificação seletiva explica uma história a partir da interconexão das outras categorias.

As categorias codificadas, categorizadas e interpretadas foram geradas por diferentes instrumentos de coleta de dados: questionário final de autoavaliação, diário dos alunos e dados do planejamento proposto (levantamento bibliográfico, análise documental, questionários aplicados aos alunos e entrevista aplicada aos profissionais da área).

\subsubsection{Triangulação}

Com o objetivo de propiciar confiabilidade e validade na pesquisa, segundo Creswell (2010), alguns procedimentos têm sido utilizados em um estudo, por exemplo, a triangulação de dados. A triangulação consiste, segundo Gibbs (2009), em cruzar diferentes amostras e conjuntos de dados, ou investigador, ou ainda métodos e teorias de pesquisa. Triangulação significa, para Flick (2009, p. 61), que "uma questão de pesquisa é considerada a partir de (pelo menos) dois pontos".

Optamos por triangular os dados resultantes dos diferentes instrumentos de coleta de dados com o objetivo de identificar as implicações do planejamento proposto no processo de ensino e aprendizagem. A triangulação não tem como objetivo criar uma interpretação única, válida e precisa da realidade (GIBBS, op.cit.), mas dar maior fidedignidade e validar a pesquisa. 


\section{CAPÍTULO 4 - ANÁLISE E DISCUSSÃO DOS DADOS}

Primeiros parágrafos

Conforme dissemos anteriormente, entendemos, para esta dissertação, a abordagem de ensinar como uma "força potencial que determina e orienta o fazer do professor" (ALMEIDA FILHO, 1993, p. 17), na qual se explicitam as suas competências de ensinar. É por meio das competências teórica e aplicada, com vistas ao desenvolvimento de uma competência profissional, que o professor-pesquisador pode desenvolver uma visão fundamentada sobre vários aspectos de sua prática, possibilitando-o formular reflexões, aplicá-las, buscar novas teorias, refletir, alterar novamente suas ações, avaliar e, assim, sucessivamente.

Sob essa perspectiva, a busca do desenvolvimento de uma competência teórica-aplicada acerca do processo de ensino e aprendizagem de línguas na EPT nos possibilitou formular algumas reflexões sobre determinados conceitos teóricos, que foram levados para discussão em eventos científicos da área, auxiliando-nos, também, na produção de outras pesquisas empíricas.

Buscar teorias, refletir e apropriar-nos de novos conceitos por meio dessas pesquisas empíricas, nos levou a retornar à literatura especializada para a delimitação das bases teóricas e para o delineamento dos possíveis elementos teórico-metodológicos do nosso planejamento de curso, que descrevemos e analisamos nas próximas páginas, seguindo o fluxo a seguir:

\section{$\checkmark$ Parte I - Da análise de objetivos ao planejamento do curso \\ $\checkmark$ Parte II - Da implementação à avaliação do planejamento do curso}

É importante ressaltar que esse fluxo foi determinando com o objetivo de responder as nossas perguntas de pesquisa, aqui retomadas:

1. Como se configurou a construção de um planejamento CLIL por tarefas para o ELFE na educação profissional técnica de nível médio subsequente?

2. Que implicações o planejamento CLIL por tarefas para o ELFE na EPT pode ter para o desenvolvimento da competência comunicativa e formação integral dos alunos a partir de suas próprias percepções? 


\section{Parte I - Da análise de objetivos ao planejamento do curso}

A primeira parte desta análise de dados apresenta as informações que nos auxiliaram a construir o nosso planejamento de curso e tem, portanto, um caráter descritivo. Foi dividida em três seções:
(A) elementos constituintes-norteadores;
(B) análise de objetivos; e
(C) descrição do planejamento proposto.

Essa divisão se deu apenas por caráter pedagógico, embora consideremos que o processo de construção de um planejamento de curso seja dialético e que seus elementos interajam e sejam complementares.

A seção A (elementos constituintes-norteadores) corresponde ao levantamento dos possíveis elementos para a construção de um planejamento de curso para o ELFE na EPT de Nível Médio (subsequente). Esses elementos foram delimitados a partir da reflexão sobre as especificidades, particularidades e propósitos desse tipo de ensino apresentados nos documentos legais e na literatura da área.

A seção B (análise de objetivos) refere-se à análise dos questionários aplicados aos alunos com a finalidade de traçar o perfil do grupo, suas necessidades e seus interesses em relação à aprendizagem da E/LE e das necessidades da situação-alvo apresentadas em documentos e em entrevistas.

E na seção C (descrição do planejamento proposto) apresentamos os conteúdos/temas e tarefas destrinchadas por meio dos dados obtidos na seção A e B.

\section{Parte II - Da implementação à avaliação do planejamento do curso}

Esta parte trata da avaliação do planejamento proposto que se deu por meio da triangulação dos dados gerados na parte I e dos dados coletados pelos instrumentos utilizados nesta parte II, ou seja, o diário do aluno e o questionário final de autoavaliação do grupo.

(Inter)conectar os dados obtidos na parte I e os gerados nessa parte II nos permitiu construir categorias de informação, relacioná-las, posicioná-las dentro do nosso referencial teórico, formulando intepretações, visões, novas reflexões e hipóteses. 


\subsection{PARTE I - DA ANÁLISE DE OBJETIVOS AO PLANEJAMENTO DO CURSO}

\subsubsection{Seção A: Elementos norteadores para a configuração do ELFE na EPT de nível técnico subsequente}

Normalmente, as decisões sobre um planejamento de curso de LE se dão em decorrência do procedimento de análise de objetivos. Essa análise intitulada, também, de análise de necessidades, tem sido apresentada na literatura como o elemento fundamental para o ELFE.

Quando abordamos um planejamento de curso para o ELFE na EPT, e em nosso caso específico em um curso técnico de nível médio (subsequente), passamos a nos questionar a quais objetivos e necessidades nos referimos, uma vez que a docência na formação profissional requer um olhar sensível para determinadas particularidades e especificidades no que tange o ensino nesse contexto.

Esses pormenores estão discutidos nas Diretrizes Curriculares Nacionais para a Educação Profissional de Nível Técnico (DCNEP), em forma de princípios, critérios e competências requeridas a esse nível para a organização de seus cursos e currículos, segundo explicitamos, de forma resumida, no quadro a seguir.

Quadro 9 - Princípios, critérios e competências da EPT técnica de nível médio para o planejamento curricular

\section{Princípios norteadores:}

I - independência e articulação com o Ensino Médio;

II - respeito aos valores estéticos, políticos e éticos;

III - desenvolvimento de competências para a laborabilidade;

IV - flexibilidade, interdisciplinaridade e contextualização;

V - identidade dos perfis profissionais de conclusão de curso;

VI - atualização permanente dos cursos e currículos;

VII - autonomia da escola em seu projeto pedagógico.

\section{Critérios para a organização e o planejamento curricular:}

I - atendimento às demandas dos cidadãos, do mercado e da sociedade;

II - conciliação das demandas identificadas com a vocação e a capacidade institucional da escola ou da rede de ensino.

\section{Competências requeridas:}

I - competências básicas, constituídas no Ensino Fundamental e Médio;

II - competências profissionais gerais, comuns aos técnicos de cada área;

III - competências profissionais específicas de cada qualificação ou habilitação.

Fonte: Diretrizes Curriculares Nacionais para a Educação Profissional de Nível Técnico (BRASIL, 1999, p. 1) 
Quanto aos seus princípios norteadores, destacamos primeiramente o da "independência e articulação com o ensino médio”. O princípio da articulação se torna mais visível no debate, em termos teóricos e práticos, nas formas articuladas de formação técnica de Nível Médio integrada e concomitante, devido à divisão de formação propedêutica (educação básica, incluindo a LE) e formação profissional; já o princípio da independência na sua forma subsequente.

Nos cursos técnicos de nível médio (integrado) e no PROEJA (integrado na modalidade jovens e adultos), a inserção da LE se faz obrigatória, devido à própria legislação do Ensino Médio vigente que, em sua organização curricular, inclui a LE como um dos componentes curriculares obrigatórios da área "Linguagens, Códigos e suas Tecnologias".

Quanto ao seu ensino na modalidade de nível técnico subsequente, a inserção da LE é entendida e determinada pela concepção do perfil profissional que se deseja formar ou determinada pela própria instituição, dado que a "escola tem autonomia em seu projeto pedagógico", podendo ou não ofertá-la, segundo as "demandas identificadas com a vocação e a capacidade institucional da escola ou da rede de ensino" (BRASIL, 1999, p. 1).

Segue a seguir, como forma de ilustração, um quadro explicitando os níveis e modalidades de EPT e sua relação com a obrigatoriedade ou não da LE.

Quadro 10 - Relação da LE com níveis e modalidades de ensino

1. FORMAÇÃO INICIAL CONTINUADA (Cursos FICs)

2. TÉCNICO DE NÍVEL MÉDIO: Integrado, Concomitante, Subsequente e PROEJA (Educação de Jovens e Adultos)

3. SUPERIOR: Tecnológico, Bacharelados e Engenharias, Licenciaturas e Pós-graduação

* nas modalidades em destaque, o ensino da LE é tido como obrigatório

A ausência da obrigatoriedade legal não impede a inserção da LE para um determinado perfil profissional, que pode vir a ter a necessidade do desenvolvimento de "competências (em LE) para a laborabilidade”. Além das competências profissionais (gerais e comuns aos técnicos de cada área e específicas de cada qualificação ou habilitação), a legislação explicita a necessidade do desenvolvimento de competências básicas guiadas para o "respeito aos valores estéticos, políticos e éticos" no atendimento "às demandas dos cidadãos, do mercado de trabalho e da sociedade".

Entendemos que as demandas, assim postas, para a LE, fazem referência às necessidades do aluno, da situação-alvo e da contemporaneidade. Consideramos que a demanda do aluno é aquilo que entende que deve saber (necessidades) e o que gostaria de saber (interesses), para 
que seja possível desempenhar o seu papel social (pessoal e profissional). Para a situação-alvo, devemos considerar "as competências profissionais gerais” do técnico de uma ou mais áreas, completadas com outras "competências específicas da habilitação profissional" (BRASIL, 2000 , p. 38), atendendo, assim, ao propósito de polivalência ${ }^{40}$ profissional, proposta na legislação vigente.

A organização curricular do curso Técnico de nível médio subsequente, centrada no perfil profissional polivalente (por isso tratamos do eixo e da área), e no entendimento de que o currículo é um meio para desenvolver competências para o trabalho e para o exercício da cidadania, deve ser pensada, portanto, a partir de questões que se fazem presentes na prática social contemporânea para o uso da LE e para a prática cidadã e a relação entre essas.

As necessidades atuais para a LE têm apontando para o desenvolvimento de uma competência comunicativa, interação como forma de reflexão, construção de valores e atitudes, entre outros, buscando atender o que representa ser relevante (profissional, pessoal e social) para o aluno.

Para atender às necessidades das pessoas, às demandas do mercado de trabalho e da sociedade, os seguintes aspectos (quadro 11) foram considerados em nosso levantamento de objetivos. Na tentativa de traçarmos uma relação entre os critérios do ELFE (análise de objetivos dos alunos e da situação-alvo) e os critérios para a organização e o planejamento curricular da EPT, bem como as competências requeridas aos profissionais em pré-servico, do nível técnico, segundo a legislação.

Quadro 11 - Critérios para o levantamento de objetivos dos alunos e necessidades da situação-alvo e da contemporaneidade do contexto pesquisado

\begin{tabular}{|l|l|}
\hline \multicolumn{1}{|c|}{$\begin{array}{c}\text { Objetivos } \\
\text { (necessidades e interesses) }\end{array}$} & \multicolumn{1}{c|}{$\begin{array}{c}\text { Necessidades } \\
\text { (demandas) }\end{array}$} \\
\hline $\begin{array}{l}\text { 1. dos alunos (cidadão) } \\
\text { - competências básicas, constituídas no Ensino } \\
\text { Fundamental e Médio; }\end{array}$ & $\begin{array}{l}\text { 2. da situação-alvo (mercado de trabalho): } \\
\text { - eixo tecnológico (competências profissionais } \\
\text { gerais, comuns aos técnicos de cada área - } \\
\text { atendendo ao princípio da polivalência); }\end{array}$ \\
\hline
\end{tabular}

\footnotetext{
${ }^{40}$ Por polivalência, aqui, se entende o atributo de um profissional possuidor de competências que lhe permitam superar os limites de uma ocupação ou campo circunscrito de trabalho, para transitar para outros campos ou ocupações da mesma área profissional ou de áreas afins. Supõe que tenha adquirido competências transferíveis, ancoradas em bases científicas e tecnológicas, e que tenha uma perspectiva evolutiva de sua formação, seja pela ampliação, seja pelo enriquecimento e transformação de seu trabalho. Permite ao profissional transcender a fragmentação das tarefas e compreender o processo global de produção, possibilitando-lhe, inclusive, influir em sua transformação (BRASIL, 1999, p. 37)
} 


\begin{tabular}{|l|l|}
\hline - competências para desempenhar o seu papel & - competências profissionais específicas de cada \\
social (pessoal e profissional) em LE. & qualificação ou habilitação. \\
& 3. contemporâneas (sociedade): \\
- competências demandadas pelo contexto & sócio-histórico-cultural: \\
- para o uso da LE \\
- conhecimentos gerais e profissionais \\
- formação da EPT
\end{tabular}

Buscamos atender a esses objetivos por meio da combinação entre conteúdo/temas, língua e tarefas, no intuito de mobilizar conhecimentos, significados, valores, atitudes para desenvolver uma CC na L-alvo, capaz de levar os alunos a integrar-se pessoal e profissionalmente no mundo, por meio da reflexão e ação. A proposta de planejamento CLIL por tarefas possibilita trabalhar com conteúdos/temas relevantes e significativos para os alunos do eixo e da área específica e do cotidiano, temas inclusive, conflitivos no intuito de levá-los a refletir, opinar, interagir no e para o uso significativo e real da língua, atendendo, assim, ao princípio da EPT que versa sobre a "flexibilidade, interdisciplinaridade e contextualização".

As tarefas, por sua vez, permitem o uso da L-alvo em situações próximas da realidade, possibilitando aos alunos agir no mundo por meio da integração de diferentes competências na busca "simultânea" de atender às demandas das pessoas, do mercado de trabalho e da sociedade (BRASIL, 2000, p. 38). Entendemos, portanto, que o planejamento CLIL, ao conectar conteúdo/temas do cotidiano e língua; experiências e atores, proporciona um ensino de LE alinhado com a contemporaneidade.

$\mathrm{O}$ ato de planejar um curso requer um olhar atento para as reais necessidades dos alunos (DEWEY, 1975; GUIMARÃES, 1995; ALMEIDA FILHO, 2013; VIANA, 2009; WAJNRYB, 1992; WOODWARD, 2001). Além dos objetivos dos alunos e da situação-alvo, fez-se necessário levantar informações quanto ao perfil do grupo, uma vez que considerar as características do grupo nos permite um olhar mais sensível sobre o planejamento (WOODWARD, op. cit.). Essas características envolvem também conhecimento prévio da Lalvo, disponibilidade de tempo, entre outros (VIANA, op. cit.), e acrescentamos, no caso do planejamento CLIL para o ELFE na EPT, a relação do aluno quanto ao acesso às fontes de informações e às oportunidades que tem no contexto de trabalho para opinar sobre elas.

Segundo Lima (2010), o educador, como ator social, precisa se posicionar e exercer o seu papel social de diferenciação na formação de opiniões de seus alunos e da comunidade, com vistas à emancipação. A emancipação do sujeito, para o autor, dá-se "por meio da ação- 
reflexão-ação na travessia do aprender a viver juntos", cabendo aos educadores "promover inferências que deem outro destino ao seu papel interventivo e ao destino de seus alunos no processo de aprender a aprender" (p. 58-15).

O educador que se compromete com esse papel assume a responsabilidade de transmitir seu conhecimento e, ao mesmo tempo, valorizar os saberes de seus alunos, já que muitos teóricos têm reforçado a importância de dar significado ao conhecimento prévio dos alunos (FREIRE, 1996; AUSUBEL, 2003). Entendemos que dar significado ao conhecimento prévio do aluno é considerá-lo como parte de um contexto histórico-sócio-cultural e poder relacionar esses saberes e os experimentados no contexto de sala de aula pode ser bastante válido.

Apresentaremos, portanto, primeiramente o resultado do levantamento do perfil e objetivos dos alunos e da situação-alvo (eixo e área) para a configuração do nosso planejamento de curso, e, em seguida, descreveremos e analisaremos o nosso planejamento proposto a partir da percepção dos alunos.

\subsubsection{Seção B: Informações coletadas a partir da análise de objetivos}

Esta seção apresenta o resultado do levantamento de objetivos dos alunos e da situaçãoalvo. No segmento dos alunos, buscamos definir o seu perfil e suas necessidades e interesses por meio de questionário. A amostra total foi de 28 alunos e os dados foram apresentados por meio de gráficos. No questionário do perfil do grupo utilizamos perguntas fechadas, onde os alunos poderiam escolher uma resposta ou mais de uma entre diversas opções, sendo assim, as estimativas foram fornecidas com valores em percentuais (\%) do total de alunos. Para a escolha de uma resposta entre várias opções, as frequências das categorias devem somar 100\% (28 alunos) e nas respostas de múltiplas escolhas, onde um mesmo aluno pode dá mais de uma resposta, poderá ultrapassar a soma de $100 \%$. Outros dados foram apresentados em nível de relevância e/ou atributo que surge com frequência, sob a forma de nomes ou categorias. Esta seção apresenta um caráter descritivo (GIL, 2009), das características da população: idade, sexo, nível de conhecimento em LE, etc.

No segmento da situação-alvo, buscamos identificar as necessidades da área em documentos e por meio de entrevista com profissionais da área. A análise dos dados, dessa fase, consistiu na codificação e categorização dos dados levantados. 


\subsubsection{Segmentos dos alunos: questionários}

\subsection{Perfil: conhecendo os alunos}

O aluno do curso técnico de nível médio subsequente em Logística do contexto pesquisado apresenta um perfil, de certa forma, irregular. O curso desse nível e modalidade atende a alunos jovens e adultos de diferentes idades. A idade predominante desse grupo de alunos é entre 18 a 35 anos (85,7\%), poucos são aqueles que têm mais de 35 anos (14,3\%). No conjunto de alunos, $57,1 \%$ são mulheres e $42 \%$ são homens. O gráfico a seguir mostra a distribuição dos alunos em relação à faixa etária e segundo o sexo:

Gráfico 1 - Idade e sexo dos alunos

\begin{tabular}{|l|l|}
\hline Menor que 18 anos & $0 \%$ \\
\hline Entre 18 a 25 anos & $32.1 \%$ \\
\hline Entre 26 a 30 anos & $28.6 \%$ \\
\hline Entre 31 a 35 anos & $25 \%$ \\
\hline Entre 36 a 40 anos & $10.7 \%$ \\
\hline Maior que 40 anos & $3.6 \%$ \\
\hline
\end{tabular}

\begin{tabular}{|l|l|}
\hline Masculino & $42.9 \%$ \\
\hline Feminino & $57.1 \%$ \\
\hline
\end{tabular}
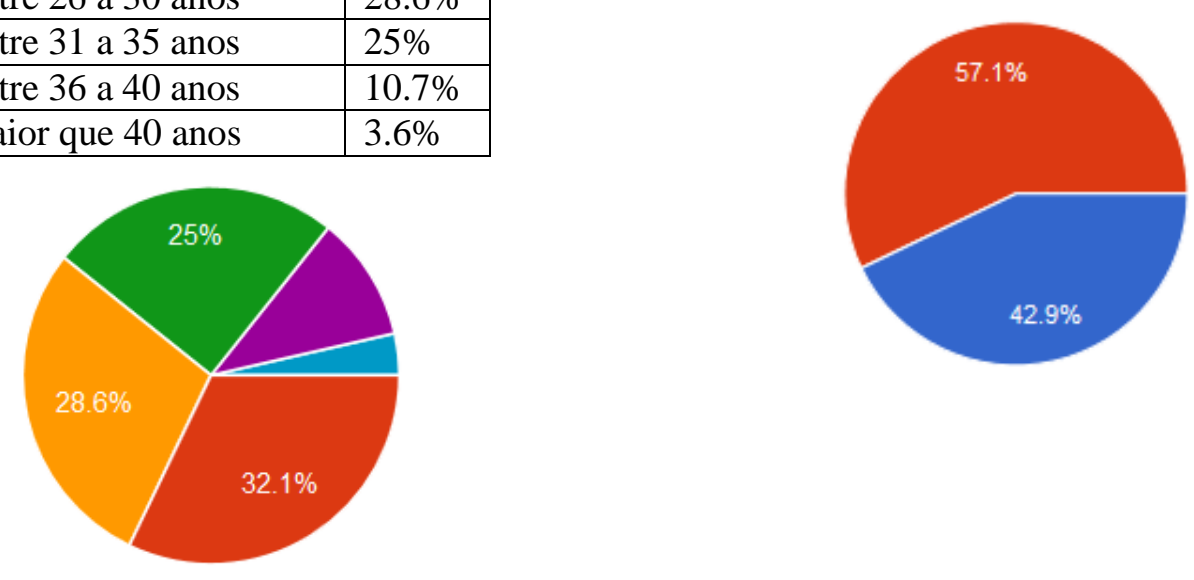

Consideramos que a sala de aula é uma extensão no universo social dos alunos. Desse universo, a maioria dos alunos $(89,2 \%)$ dedica grande parte a horas de trabalho remuneradas e outras 4 horas diárias para o ensino formal, não sobrando, muitas vezes, espaço para outros convívios sociais.

Gráfico 2 - Situação laboral dos alunos

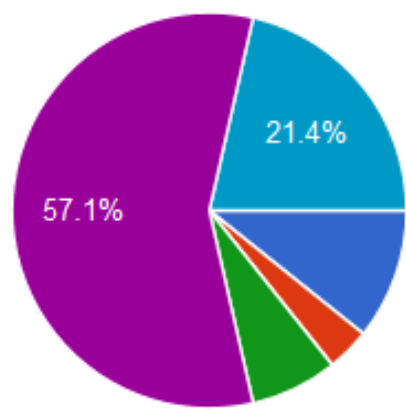

\begin{tabular}{|l|l|}
\hline NÃO & $10.7 \%$ \\
\hline Sim, mas é trabalho eventual & $3.6 \%$ \\
\hline Sim, 20 horas por semana & $0 \%$ \\
\hline Sim, 30 horas por semana & $7.1 \%$ \\
\hline Sim, 40 horas por semana & $57.1 \%$ \\
\hline Sim, 44 horas por semana & $21.4 \%$ \\
\hline Outros & $0 \%$ \\
\hline
\end{tabular}


Entendemos que a escola deve proporcionar convivência significativa e interessante aos alunos, buscando, além de novos saberes, trabalhar "com a totalidade das dimensões do sujeito e não apenas com aspectos específicos como comportamento, habilitação para o trabalho, qualificação para o mercado, ou ainda conscientização política” que inclui, portanto, a responsabilidade do professor para a formação da autonomia dos alunos (ARROYO, 2001 apud MORIGI, 2012 p. 35).

(...) o ser humano precisa ter autonomia e maturidade para tomar decisões. O objetivo é formar sujeitos conscientes e éticos, mas a dimensão ética implica na identificação dos valores populares (...) partir de uma pedagogia que reconhece os valores do povo (...) como sujeito de sua própria cultura, enquanto conjunto de sujeitos culturais, estéticos.

Nessa perspectiva, consideramos importante verificar a relação dos alunos com as fontes de informações, importância e tempo que conferem a elas no dia a dia laboral, entre outros aspectos. Foi questionado aos alunos se, no trabalho, eles têm a oportunidade de conversar com os colegas. Observamos que mais da metade $(60 \%)$ tem a oportunidade dialogar durante o horário de trabalho, e $32 \%$ apenas durante intervalos e horário de almoço, conforme ilustra o gráfico 3 .

Gráfico 3 - Oportunidades conversacionais dos alunos no ambiente de trabalho

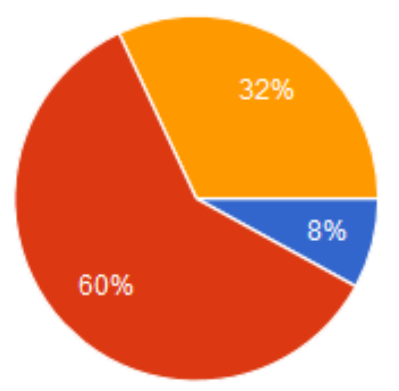

\begin{tabular}{|l|l|}
\hline Não é permitido conversar & $8 \%$ \\
\hline $\begin{array}{l}\text { Converso com os colegas, } \\
\text { durante o expediente }\end{array}$ & $60 \%$ \\
\hline $\begin{array}{l}\text { Converso durante intervalos } \\
\text { e na hora do almoço }\end{array}$ & $32 \%$ \\
\hline Outros & $0 \%$ \\
\hline
\end{tabular}

Quanto ao tipo de conversa que mantêm com colegas de trabalho (pergunta aberta), as opiniões variaram: sobre a vida pessoal, problemas cotidianos, a própria dinâmica da empresa, notícias do dia, casos, descontração.

Apesar da maioria $(78,5 \%)$ trabalhar 40 ou mais horas semanais, os alunos buscam tempo para manterem-se informados por meio das facilidades que hoje a vida em sociedade oferece, como a internet e telejornais (meios de informação declarados pela maioria) e assim sucessivamente, conforme ilustra o gráfico a seguir. 
Gráfico 4 - Fontes de informações mais acessadas pelos alunos

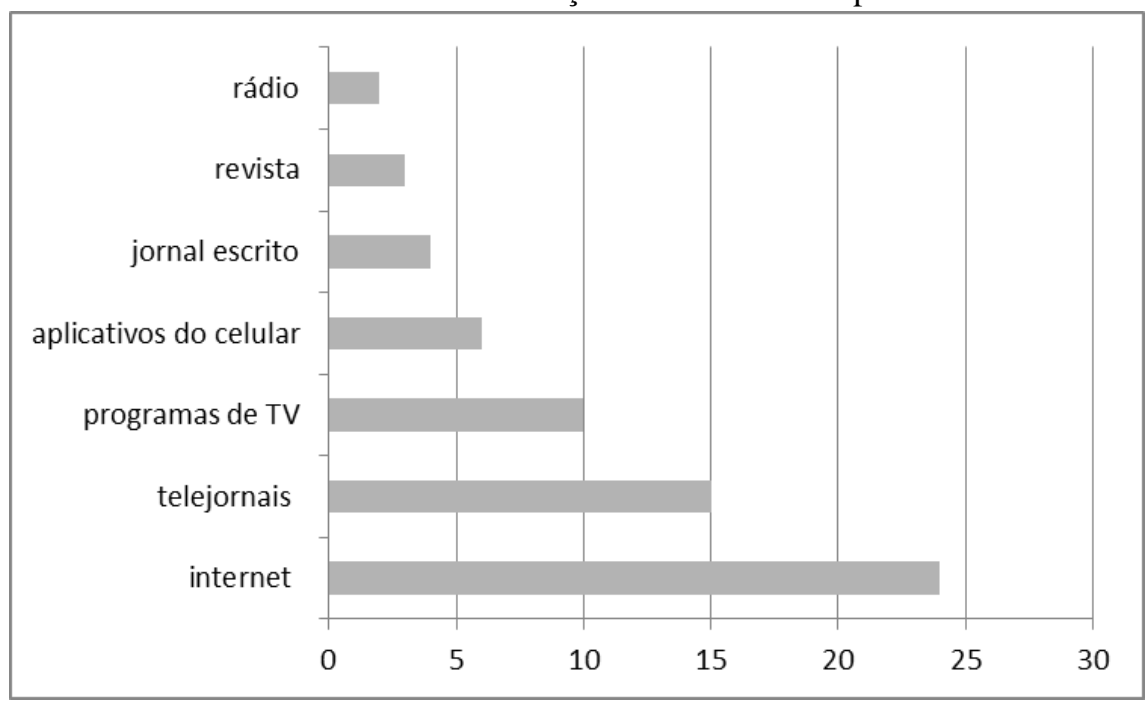

Buscamos identificar, também, os tipos de informação que mais interessam aos alunos. Essa pergunta, assim como a anterior, possibilitou múltiplas respostas. Os alunos apresentam maior interesse pelas notícias diárias locais e/ou nacionais, em seguida aparece o interesse por temas relacionados à política, logo para notícias do mundo cultura/lazer, esportes e sobre relacionamentos.

Gráfico 5 - Assuntos que interessam aos alunos

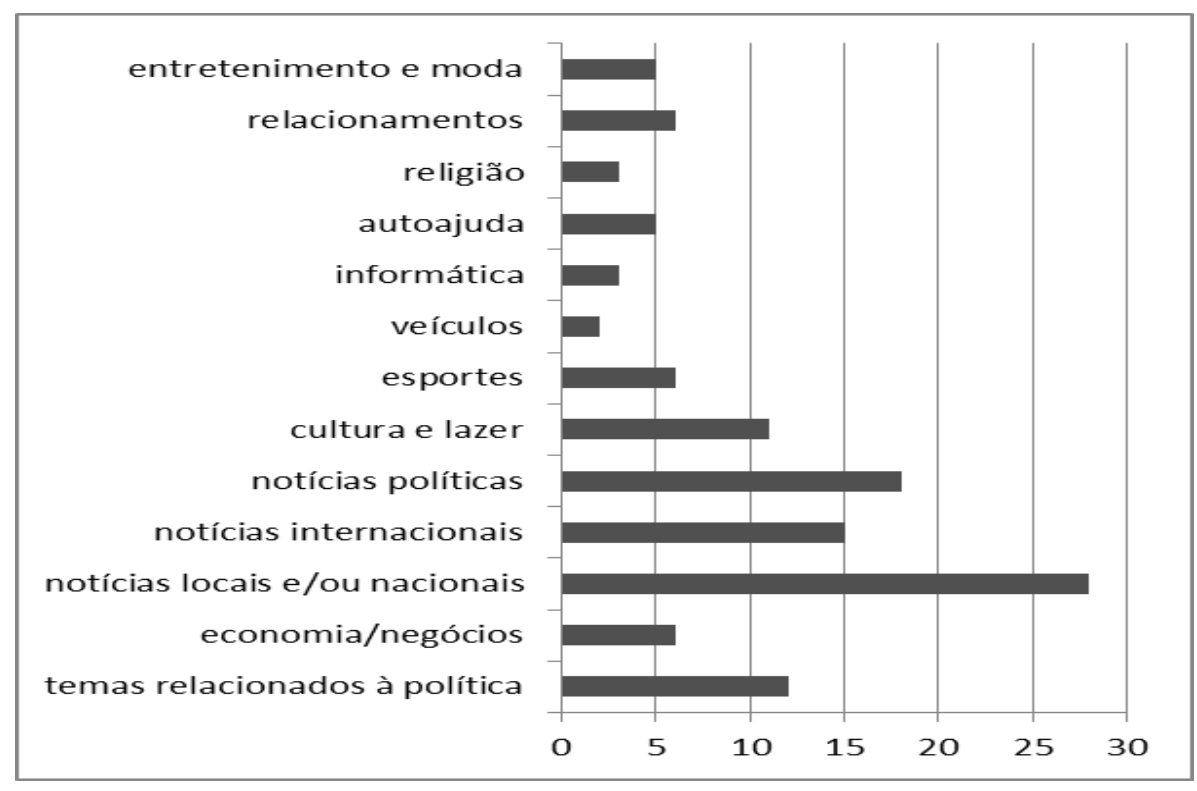

Quanto à frequência em que buscam essas informações, mais da metade (64,2\%) informa que diariamente.

Buscamos conhecer, ainda, os motivos que levaram cada um a escolher o curso técnico em Logística e as respostas variam entre motivos pessoais e profissionais. Para a maioria 
(85,7\%), a motivação se deu pela realização pessoal e mais da metade (64,2\%) para o desenvolvimento como pessoa e para a aquisição de cultura geral. Quanto aos motivos de cunho profissional, apesar de não ser a profissão desejada por muitos dos alunos, sendo essa a escolha para apenas $(32,1 \%)$, todos os alunos (28 alunos - 100\%) acreditam que a formação profissional pode proporcionar maiores oportunidades no mercado de trabalho, melhores perspectivas de ganhos materiais e a grande maioria $(85,7 \%)$ acredita que pode melhorar na situação atual laboral. Quanto a outros fatores, a maioria $(82,1 \%)$ aponta para a questão da gratuidade do curso e $(78,5 \%)$ para o fato do curso ser noturno. Por fim, $(64,2 \%)$ afirmam também que buscaram o curso por sua qualidade.

Tentamos, então, levantar a percepção geral que cada aluno tem sobre o curso técnico em Logística desde que ingressaram nele, além de algumas características que consideram importantes em um bom profissional.

Quanto à percepção geral sobre o curso, destacamos as respostas apresentadas por mais da metade dos alunos (acima de 50\%): 85,7\% acreditam que o curso contribui para o desenvolvimento do potencial de aprendizagem do estudante e $(78,5 \%)$ que o curso fomenta a formação integral por meio de uma visão global do contexto no qual o estudante está inserido. $75 \%$ dos alunos informaram que o curso contribui para a reflexão sobre a realidade social brasileira e declaram que estão satisfeitos em relação ao nível de aprendizagem e inserção no mercado de trabalho para os estudantes. Para muitos $(64,2 \%)$, o curso está com a grade curricular atualizada em relação ao mercado e, além disso, consideram que os conteúdos/programas auxiliaram na formação pessoal e profissional.

Quanto às características que consideram importantes para um profissional na atualidade, todas as caraterísticas foram igualmente consideradas como: comunicação eficaz; domínio de língua estrangeira; conhecimento técnico; criatividade e inovação; compromisso social; ética profissional; capacidade de trabalho em equipe; articulação e argumentação; criticidade; liderança; solucionar conflitos; visão do todo; e aprendizado contínuo. Seria viável, para esta pergunta, um caráter de formulação aberta, a fim de percebemos individualmente suas próprias percepções quanto ao bom profissional.

Observamos, assim, que, para o aluno da EPT técnica de nível médio, a escola tem um papel social importante, na medida em que se preocupa com questões vinculadas ao desenvolvimento de competências profissionais e pessoais para a vida em sociedade. Os alunos têm acesso às várias informações vinculadas diariamente e se mostram interessados em compartilhá-las. 
Entendemos que cabe ao Estado cumprir com o seu dever de levar a educação para todos (e é importante considerar a potencialidade de programas de formação profissional que atuam com grupos sociais mais vulneráveis), e cabe à sociedade (incluindo professores e alunos) cumprir o papel de compartilhar da educação e estimular a autonomia de todos os envolvidos.

Passamos a detalhar a relação dos alunos com a língua espanhola, seus objetivos (necessidades e interesses) e também o seu conhecimento-prévio na língua. O resultado dessa análise nos proporcionou ferramentas para construir modos de conduzir as aulas por meio de um planejamento que levasse os alunos a experimentar um pensamento crítico, autônomo, dialógico por meio da relação conteúdos/temas e língua em um sentido simultâneo.

\subsection{Necessidades e Interesses: conhecendo os objetivos dos alunos}

\section{$\checkmark$ O aluno e sua relação com a língua espanhola}

Com relação ao contato com a língua espanhola, 50\% dos respondentes afirmaram já ter tido contato (pessoalmente) com a língua espanhola anteriormente, conforme ilustramos no quadro a seguir:

Quadro 12 - Ocasiões e tempo de contato com o E/LE x quantidade de alunos

OCASIÕES DE CONTATO COM A E/LE ALUNOS

\begin{tabular}{lcl}
\hline Ensino Fundamental & $10,7 \%$ & (2) Por 1 ano. (1) Período letivo. \\
Ensino Médio & $21,4 \%$ & (3) 1 ano. (1) Há 16 anos. (1) Há \\
& & 18 anos. (1)3 anos \\
Viagem ao exterior & $0 \%$ & - \\
Cursos Particulares & $3,5 \%$ & 3 meses \\
No trabalho & $7,1 \%$ & (1) 1 ano. (1) Alguns meses \\
Amigos & $3,5 \%$ & Poucas vezes \\
Outros & $3,5 \%$ & Não me lembro precisamente \\
\hline
\end{tabular}

Quanto ao nível que consideram ter em E/LE, (42,8\%) afirmam que nenhum; $(57,1 \%)$ um nível básico. Foram questionados, ainda, a respeito de outras formas de contato (atividades) com a E/LE e a frequência que a realizam, como escutar músicas em espanhol, ver filmes ou programas de TV, ler revistas e jornais pela internet, ou livros, gibis e ainda ter conversas com pessoas em espanhol pela internet. Para esta análise, levamos em consideração as variações das respostas em “às vezes”. 
Podemos dizer, portanto, que temos uma turma heterogênea e de contexto adverso.

O contexto adverso é formado por alunos sem experiências com e na língua-alvo e que trabalham o dia todo, não dispondo dessa maneira, de tempo para estudar. Frequentam um curso noturno, estão longe da escola há anos. Eles têm pouco ou nenhum contato com a língua-alvo fora da sala de aula (BARBIRATO, 2005, p, 16).

Pode-se notar que, apesar do pouco contato que tiveram com a língua espanhola no decorrer da vida estudantil, outras formas de contato foram mencionadas (gráfico 6), como a música espanhola pela maioria. Outros, por sua vez, já viram alguma notícia em revistas ou jornais na internet, alguns já assistiram filmes, outros já falaram com pessoas pela internet e algum aluno já teve contato com gibi em espanhol.

Gráfico 6- Formas de contato que os alunos tiveram com E/LE

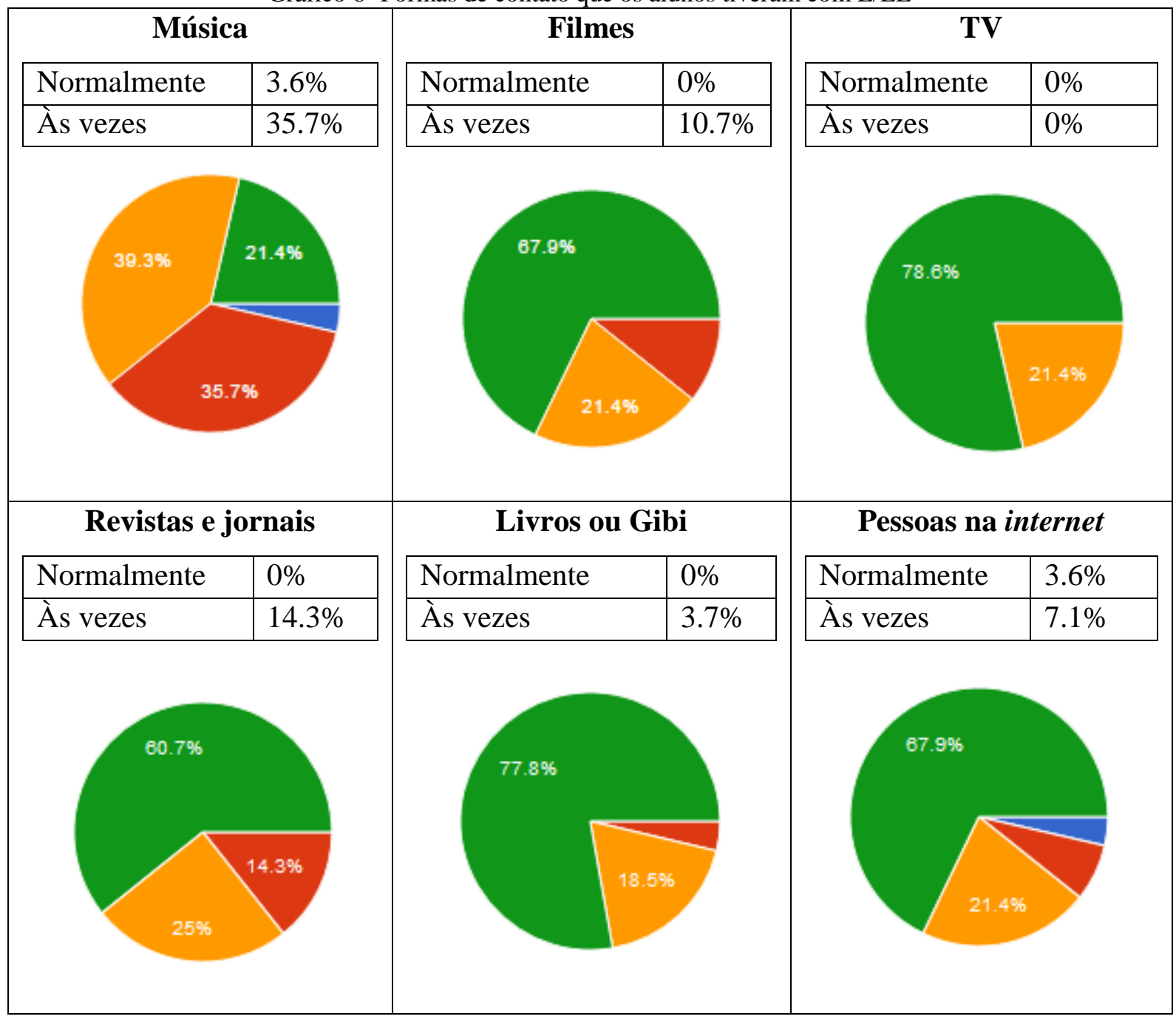

Quando questionado aos alunos “em sua opinião, qual a importância do aprendizado de uma língua estrangeira, atualmente", é possível perceber que eles têm consciência da 
importância da aprendizagem de uma língua estrangeira, e acreditam, principalmente, que ela possibilita avanço na carreira profissional. Citam, ainda, a importância da LE num mundo globalizado, vendo que ela amplia as opções para o acesso à informação (filmes, jornais, documentários, entrevistas, novelas, etc.), aumenta as opções de lazer (viajar para outros países) e, além disso, muitos consideram a aprendizagem importante na sua participação social. Os excertos a seguir ilustram as respostas dos participantes sobre a importância que atribuem ao ensino de LE na atualidade.

Solicitamos ainda que os alunos opinassem sobre qual deveria ser o papel da LE em curso técnico pensando nas necessidades contemporâneas, selecionando (3) entre as opções apresentadas de maior importância para eles. Apresentamos a lista conforme relevância para os alunos:

1. Possibilitar o acesso às informações e ao conhecimento produzido;

2. Compreender e expressar, oralmente e por escrito, opiniões e ideias, entendendo a comunicação como troca de valores culturais;

3. Compreender e produzir linguagem oral e escrita exigida em seu contexto profissional;

4. Aprender termos básicos e expressões de uso corrente da língua espanhola;

5. Possibilitar maior entendimento de seu próprio papel como cidadão do país e do mundo em que vive, por meio de discussões de temas diversos na língua estrangeira;

6. Aprender frases padrões e funções (como cumprimentar, pedir ajuda, etc.) das situações comunicativas do ambiente de trabalho;

7. Ler e interpretar textos da área;

8. Estudar vocabulário e termos técnicos da área;

9. Compreender e redigir textos técnicos e documentos de natureza variada;

10. Conhecimento sistêmico da língua (gramática, norma padrão).

\section{$\checkmark$ Necessidades e interesses}

Buscamos identificar as necessidades e interesses dos alunos por meio de questionário. A primeira corresponde as suas necessidades (aquilo que entende que precisa saber para lidar profissional e pessoalmente com a L-alvo) e, por último, seus interesses (o que gostariam de aprender). Além dos objetivos dos cursos a partir de suas necessidades e interesses, buscamos identificar quais as formas de interação, procedimentos e técnicas que eles gostariam que fossem trabalhadas com maior frequência. 
Segundo Gibbs (2009), uma atividade fundamental na codificação é procurar passagens semelhantes que podem ser termos, palavras ou expressões, formando tópicos parecidos. Para o autor, os participantes podem estar expressando a mesma coisa de outra forma, utilizando termos equivalentes ou sinônimos do que estamos procurando.

A codificação, para o autor (op. cit.), pode ser usada de várias formas, porém a mais comum é a categorização do conteúdo temático dos dados. No entanto, a codificação pode ser usada de forma mais idiossincrática, junto com outras formas de marcar o texto (destacar, circular, sublinhar, comentar).

Entre as necessidades, destacamos e agrupamos as respostas com base em passagens semelhantes. Tendo em vista tal codificação, foi possível estabelecer uma família de categorias.

A primeira codificação foi a de tipo aberta, listando todas as respostas (necessidades dos alunos pensando na área) e interesses, com o objetivo de associar as respostas. Nesta etapa, os códigos gerados foram: qualificar para o mercado de trabalho; novos conhecimentos; noção básica da língua espanhola; conhecimentos para usar no dia a dia; vocabulário do espanhol; conversação; as habilidades linguísticas (separadas ou combinadas 2 ou 3); ou, ainda, todas juntas.

O próximo passo foi a codificação axial que relaciona as categorias anteriores listadas e categorias mais reduzidas. O objetivo é aprimorar, aperfeiçoar as categorias, estabelecendo relações entre elas.

Dessa forma, optou-se por trabalhar as categorias e sua relação entre as duas perguntas: o que você considera ser necessário saber em língua estrangeira para lidar eficazmente em determinadas situações no âmbito pessoal e profissional (pensando nas necessidades de sua área)? O que você gostaria de aprender (seus interesses) em espanhol durante este curso?

Nessa última categoria, "a seletiva" que dá continuidade à codificação axial (FLICK, 2009, p. 288), foi possível perceber que necessidades e interesses se aglutinam. O que para alguns alunos foi considerado como necessidade, pensando na área, para outro aluno seria um interesse.

Este tipo de codificação nos permitiu um panorama geral, gerando uma categoria central e outras a ela relacionadas.

Quadro 13 - Necessidades e interesses dos alunos do contexto pesquisado

\begin{tabular}{|l|l|l|}
\hline \multicolumn{2}{l}{ Quadro 13 - Necessidades e interesses dos alunos do contexto pesquisado } \\
\hline Trabalho & \multicolumn{1}{|c|}{ Necessidades dos alunos } & \multicolumn{1}{c|}{ Interesses dos alunos } \\
& Mercado de trabalho. & A importância da língua \\
& Qualificação. & espanhola nos cursos técnicos. \\
& Vocabulário para usar no trabalho. & Formas de negociação. \\
\hline
\end{tabular}




\begin{tabular}{|c|c|c|}
\hline Dia a dia & Frases usuais. & $\begin{array}{l}\text { A língua em uso no cotidiano. } \\
\text { Frases usuais. } \\
\text { Para me virar no dia a dia. }\end{array}$ \\
\hline $\begin{array}{l}\text { Habilidades } \\
\text { Linguísticas }\end{array}$ & $\begin{array}{l}\text { Ênfase na escrita. } \\
\text { Escrita e a conversação. } \\
\text { Falar e entender um pouco de espanhol. } \\
\text { Noções básicas de leitura e } \\
\text { compreensão da língua espanhola. } \\
\text { Aulas de conversação. } \\
\text { Comunicação sem muita gramática. } \\
\text { Queria poder entender e falar alguma } \\
\text { coisa. } \\
\text { Adquirir entendimento ou escrever um } \\
\text { pouco é essencial. } \\
\text { O necessário para poder falar e } \\
\text { compreender o que outras pessoas } \\
\text { falam. } \\
\text { De maneira dinâmica, rápida e prática, } \\
\text { aprender a falar, escrever, ler e } \\
\text { compreender os outros (uma música, } \\
\text { um filme). } \\
\text { Entender a língua após o curso. }\end{array}$ & $\begin{array}{l}\text { Conversação. } \\
\text { Falar com as pessoas. } \\
\text { A pronúncia e a escrita corretas. } \\
\text { Como escrever um espanhol } \\
\text { correto. } \\
\text { Falar e escrever um pouco. } \\
\text { A escrever, falar, entender, ler, } \\
\text { melhorar minha compreensão, } \\
\text { desenvolver minha escrita e } \\
\text { melhorar minha fala. } \\
\text { Interagir com estrangeiros, ler } \\
\text { documentos e livros em outras } \\
\text { línguas. } \\
\text { Espero poder ler, escrever, falar e } \\
\text { entender algumas coisas. } \\
\text { Entender a fala e a praticidade da } \\
\text { escrita. } \\
\text { Falar um pouco e entender as } \\
\text { pessoas. } \\
\text { Poder conversar sem ter } \\
\text { vergonha. Tirar o medo de falar } \\
\text { quando estou perto de alguém de } \\
\text { outro país. } \\
\text { Conseguir me comunicar e } \\
\text { conversar com essa pessoa. }\end{array}$ \\
\hline Básico & $\begin{array}{l}\text { Aprender pelo menos o básico. } \\
\text { O básico da língua. } \\
\text { Ter uma noção básica. } \\
\text { Conhecimento básico na língua } \\
\text { espanhola. } \\
\text { Espanhol básico. }\end{array}$ & Falar pelo menos o básico. \\
\hline Oportunidade & $\begin{array}{l}\text { Aprimorar quem já possui algum } \\
\text { conhecimento e desenvolver e ensinar } \\
\text { novos caminhos. } \\
\text { Aprimorar conhecimentos e novas } \\
\text { oportunidades. } \\
\text { Uma oportunidade para conhecemos } \\
\text { melhor a língua espanhola. }\end{array}$ & $\begin{array}{l}\text { O que for disponibilizado em } \\
\text { conteúdo pelo curso e dado em } \\
\text { sala de aula. } \\
\text { Gosto muito desta língua, e tudo } \\
\text { o que este curso puder oferecer } \\
\text { vou aproveitar. }\end{array}$ \\
\hline
\end{tabular}


As necessidades e interesses dos alunos se relacionam à importância do desenvolvimento da língua (básica) no seu uso (falar, ler, escrever, entender e ser entendido) em situações cotidianas e de trabalho, aprendizagem do vocabulário de uso profissional, frases usuais do dia a dia. Para muitos, aprender língua está relacionado a novos conhecimentos e novas oportunidades.

Quanto aos temas a serem trabalhados em sala, foi solicitado aos alunos que pensassem em temas para a área e temas gerais. Os assuntos estão listados segundo a maior relevância para os alunos.

Quadro 14 - Temas de interesse dos alunos do contexto pesquisado

\begin{tabular}{|c|c|}
\hline Conteúdos/Temas da área & Temais Gerais (Cotidianos) \\
\hline $\begin{array}{l}\checkmark \text { Comércio Exterior e Mercado } \\
\text { Internacional } \\
\checkmark \text { Mercosul } \\
\checkmark \text { Logística Internacional (documentos, } \\
\text { formas de fiscalizações em outros países) } \\
\checkmark \text { A Logística em outros países } \\
\checkmark \text { Logística (a parte administrativa de todo } \\
\text { processo logístico na sua cadeia). } \\
\checkmark \text { Importação e exportação (notas fiscais, } \\
\text { procedimentos e documentos) } \\
\checkmark \text { Direito tributário internacional } \\
\checkmark \text { Comércio } \\
\checkmark \text { Vendas } \\
\checkmark \text { Negociações } \\
\checkmark \text { Administração } \\
\checkmark \text { Transportes } \\
\checkmark \text { Comunicação, tramitação, um pouco na } \\
\text { área administrativa, distribuição } \\
\checkmark \text { Contabilidade } \\
\checkmark \text { Saúde e Segurança do Trabalho } \\
\checkmark \text { Temas que estudamos nas outras matérias }\end{array}$ & $\begin{array}{l}\checkmark \text { Aspectos administrativos de empresas } \\
\checkmark \text { Situações problemas do dia a dia } \\
\checkmark \text { Conversas livres em espanhol } \\
\checkmark \text { Trocar ideias, experiências } \\
\checkmark \text { Procedimentos em portos e aeroportos e } \\
\text { ferrovias } \\
\checkmark \quad \text { Tenho interesse e curiosidade de saber } \\
\text { um pouco de cada tema } \\
\checkmark \text { Temas atuais, em jornais, revistas. } \\
\checkmark \text { Aceitação da linguagem espanhola no } \\
\text { mundo } \\
\checkmark \text { Atualidades } \\
\checkmark \text { Filmes, músicas, pronúncias, formas de } \\
\text { escrita } \\
\checkmark \text { Cultura dos países que falam espanhol } \\
\checkmark \text { Notícias importantes de jornais } \\
\checkmark \text { Notícias gerais do mundo da gestão } \\
\checkmark \text { O mundo do trabalho } \\
\checkmark \text { Temas atuais, para que possamos ficar } \\
\text { informados do que acontece em outros países }\end{array}$ \\
\hline
\end{tabular}

Buscamos, ainda, identificar as preferências dos alunos em relação aos procedimentos e técnicas e formas de interação que poderiam ser desenvolvidas em sala de aula, de forma que elas nos ajudassem a diversificar as tarefas comunicativas e possibilitadoras.

Simular diálogos, discutir assuntos do dia a dia, conversas livres em espanhol foram citados pela maioria dos alunos $(67,8 \%)$, seguidos de prática de pronúncia, escutar músicas, assistir a vídeos e filmes, atividades em dupla/grupo (64,2\%); seguida de troca de ideias e de 
opiniões e atividades de completar informações que escutaram (60,7\%). Todas as formas de interações apresentadas na lista de opções no questionário foram mencionadas e, para a opção "outras atividades", houve o acréscimo para o trabalho com teatro em sala de aula.

\subsubsection{Segmento da Situação-alvo: documentos e entrevistas}

\subsection{Eixo tecnológico: Gestão e Negócios}

Para esta análise, buscamos agrupar conteúdos/temas e tarefas comuns entre as diferentes áreas do eixo Gestão e Negócios com a finalidade de aplicá-los à LE. Para tanto, foi analisado o catálogo de cursos técnicos (apêndice G) e ofertas de trabalhos. Para cada eixo foram, levantadas 10 ofertas públicas de trabalho em sites de busca para essa finalidade (Empregos.com, Catho e Injobs).

Foram delimitados conteúdos/temas e tarefas para cada área do eixo tecnológico, por meio de codificação aberta e axial. E, por fim, em uma codificação seletiva, foi possível traçar a relação entre as 17 áreas do eixo tecnológico, objeto deste estudo.

Quadro 15 - Relação entre as 17 áreas do eixo Gestão e Negócios

\begin{tabular}{|c|c|c|}
\hline Área & Conteúdos/Temas & Ações \\
\hline $\begin{array}{l}1 . \\
\text { Administração }\end{array}$ & $\begin{array}{lr}\text { Documentação; Produtos, } \\
\text { serviços, material e bens; } \\
\text { Estoque; } & \text { Arquivo e } \\
\text { protocolo; } & \text { Recursos } \\
\text { humanos; } & \text { Compras, } \\
\text { relatórios; } & \text { Rotinas } \\
\text { administrativas. } & \end{array}$ & $\begin{array}{l}\text { Atuar na parte administrativa: faturamento, } \\
\text { compras, financeiro, controle de arquivos e } \\
\text { documentos, elaboração de relatórios. } \\
\text { Atuar com atendimento, captação e prospecção } \\
\text { de clientes via telefone e presencialmente. } \\
\text { Participar de reuniões e visitas técnicas com } \\
\text { fornecedores. }\end{array}$ \\
\hline 2. Comércio & $\begin{array}{l}\text { Comercialização; } \\
\text { Produtos; Logística; } \\
\text { Documentação } \\
\text { comercial; } \\
\text { Fornecedores. }\end{array}$ & $\begin{array}{l}\text { Atuar na prospecção de clientes, visita } \\
\text { comercial para a apresentação da empresa e } \\
\text { dos produtos, vendas externas. Vender } \\
\text { mercadorias em estabelecimentos do comércio } \\
\text { varejista ou atacadista, atendimento ao cliente, } \\
\text { controle de estoque e realização de inventário } \\
\text { de produtos para reposição. }\end{array}$ \\
\hline $\begin{array}{l}\text { 3. Comércio } \\
\text { Exterior }\end{array}$ & $\begin{array}{l}\text { Transações comerciais } \\
\text { nacionais } \\
\text { internacionais; } \\
\text { Documentação; } \\
\text { Transporte } \\
\text { armazenamento; } \\
\text { Logística; Marketing; } \\
\text { Clientes; Vendas. }\end{array}$ & $\begin{array}{l}\text { Atuar com controle de documentação e cargas. } \\
\text { Atuar no atendimento e vendas externas. } \\
\text { Captar novos clientes, elaborar relatórios. } \\
\text { Participar de feiras e eventos comerciais. }\end{array}$ \\
\hline 4. Contabilidade & Documentos; & contábil, \\
\hline
\end{tabular}




\begin{tabular}{|c|c|c|}
\hline & $\begin{array}{l}\text { Organização empresarial; } \\
\text { Custos e patrimônio; } \\
\text { Recursos humanos. }\end{array}$ & $\begin{array}{l}\text { fechamento de balancetes mensais e anuais. } \\
\text { Controlar fluxo de caixa. } \\
\text { Atuar com rotinas de contas a pagar e receber } \\
\text { (receita e despesas), folhas de pagamento, } \\
\text { rescisões, tributos. }\end{array}$ \\
\hline $\begin{array}{l}5 . \\
\text { Cooperativismo }\end{array}$ & Marketing; Negociação. & $\begin{array}{l}\text { Consultoria em gestão empresarial. } \\
\text { Ministrar curso de associativismo e } \\
\text { cooperativismo. } \\
\text { Atuar em rotinas administrativas: listar } \\
\text { pedidos, conferir estoque, gerar etiquetas, } \\
\text { faturar pedidos, fazer inventário, emitir notas } \\
\text { ficais e boletos. }\end{array}$ \\
\hline 6. Finanças & $\begin{array}{lr}\text { Custos; } & \text { Estoques; } \\
\text { Administração } & \text { contábil, } \\
\text { fiscal e de } & \text { recursos } \\
\text { humanos. } & \end{array}$ & $\begin{array}{l}\text { Conciliar extratos bancários. } \\
\text { Enviar faturas e boletos bancários } \\
\text { Atuar no fechamento de caixa }\end{array}$ \\
\hline 7. Logística ${ }^{41}$ & $\begin{array}{l}\text { Transporte } \\
\text { armazenamento, } \\
\text { Logística; Compras, } \\
\text { recebimentos, } \\
\text { armazenagem, } \\
\text { movimentação, } \\
\text { expedição, distribuição } \\
\text { de materiais e produtos; } \\
\text { Gestão de pessoas; } \\
\text { Custos; Estoques; } \\
\text { Clientes; Almoxarifado; } \\
\text { Rotinas administrativas; } \\
\text { Vendas. }\end{array}$ & $\begin{array}{l}\text { Atuar com expedição, conferência, inspeção, } \\
\text { recebimento, monitorar, acompanhamento } \\
\text { roteirização, rastreio, controle, organização e } \\
\text { gerência de frotas, fretes, embarques, } \\
\text { estocagem, notas, contratos, motoristas, } \\
\text { transportadoras e recursos móveis. } \\
\text { Atuar na separação, armazenamento, } \\
\text { estocagem e recebimento de matérias primas, } \\
\text { componentes, produtos acabados e insumos. } \\
\text { Atender a solicitações dos clientes. } \\
\text { Emitir relatórios e alimentar sistema } \\
\text { Atuar em rotinas administrativas. }\end{array}$ \\
\hline 8. Marketing & $\begin{array}{lr}\text { Marketing; } & \text { Análise de } \\
\text { vendas; } & \text { preços e } \\
\text { produtos; } & \text { Clientes, } \\
\text { Produtos; } & \text { Logística, } \\
\text { Comunicação. } & \end{array}$ & $\begin{array}{l}\text { Atuar na gestão do acompanhamento de } \\
\text { indicadores } \\
\text { Atuar na criação de material publicitário. } \\
\text { Efetuar vendas, dar informações sobre } \\
\text { produtos. } \\
\text { Tirar dúvidas dos clientes sobre os produtos } \\
\text { por e-mail, chat e telefone. } \\
\text { Preencher relatórios e alimentar planilhas. }\end{array}$ \\
\hline 9. Qualidade & $\begin{array}{l}\text { Produto; Comunicação; } \\
\text { Certificações, Controle. }\end{array}$ & $\begin{array}{l}\text { Utilizar instrumentos - software, planilhas, } \\
\text { normas, indicadores, especificações - para } \\
\text { gerenciar o controle de qualidade. }\end{array}$ \\
\hline $\begin{array}{l}\text { 10. Recursos } \\
\text { Humanos }\end{array}$ & $\begin{array}{l}\text { Comunicação, Gestão e } \\
\text { organização do trabalho; } \\
\text { Recrutamento. }\end{array}$ & $\begin{array}{l}\text { Atuar com processos de recrutamento, seleção, } \\
\text { entrevistas, demissões, folha de pagamento e } \\
\text { demais funções administrativas e rotina de } \\
\text { departamento pessoal. }\end{array}$ \\
\hline 11. Secretariado & Documentos; & Atuar na área administrativa operacional e \\
\hline
\end{tabular}

${ }^{41}$ Além dessas, foi verificado, entre as datas de 01 de dezembro de 2013 e 31 de janeiro de 2014, em jornais e internet, o perfil para o preenchimento do cargo de analista/assistente em Logística (nível técnico). 


\begin{tabular}{|c|c|c|}
\hline & Atendimento ao público. & $\begin{array}{l}\text { administrativa. } \\
\text { Realizar atendimento ao público. } \\
\text { Elaborar relatórios e planilhas. } \\
\text { Cadastrar dados no sistema. } \\
\text { Organizar pastas e arquivos, reuniões, agenda. }\end{array}$ \\
\hline 12. Seguros & $\begin{array}{l}\text { Comercialização; } \\
\text { Cotação; Clientes; } \\
\text { Cadastro. }\end{array}$ & $\begin{array}{l}\text { Atuar no recebimento de contratos e cadastros. } \\
\text { Realizar controle de documentos. } \\
\text { Captar novos clientes. }\end{array}$ \\
\hline $\begin{array}{l}\text { 13. Serviços de } \\
\text { Condomínio }\end{array}$ & $\begin{array}{l}\text { Administração financeira, } \\
\text { de pessoal e de materiais. }\end{array}$ & $\begin{array}{l}\text { Atuar no departamento de administração de } \\
\text { condomínio, gerenciar a carteira de clientes e } \\
\text { rotinas do setor. Prestar o atendimento a } \\
\text { síndicos, moradores e fornecedores para } \\
\text { solução de problemas, supervisionar os } \\
\text { serviços da assistente e manter em ordem as } \\
\text { rotinas do setor administrativo. Atuar com } \\
\text { gestão de contratos, documentos, elaboração } \\
\text { de comunicados, seleção de débitos para } \\
\text { cobrança judicial e distribuição de } \\
\text { documentos. Manter o controle de emissão de } \\
\text { boletos, previsão orçamentária, cobranças e } \\
\text { remuneração dos síndicos. Participar de } \\
\text { reuniões e assembleias de condomínios, } \\
\text { providenciando o cumprimento das } \\
\text { deliberações. }\end{array}$ \\
\hline $\begin{array}{l}\text { 14. Serviços } \\
\text { Jurídicos }\end{array}$ & $\begin{array}{l}\text { Documentos, } \\
\text { atendimento ao público, } \\
\text { redação, qualidade. }\end{array}$ & $\begin{array}{l}\text { Ajudar os advogados nos assuntos pertinentes } \\
\text { ao grupo: cadastro na Receita Federal, } \\
\text { formulários na junta comercial, registro em } \\
\text { cartório, etc. }\end{array}$ \\
\hline $\begin{array}{l}\text { 15. Serviços } \\
\text { Públicos }\end{array}$ & Atendimento ao público. & $\begin{array}{l}\text { Será responsável pela captação de empresas } \\
\text { privadas interessadas em participar de } \\
\text { licitações públicas. Realizará visitas às } \\
\text { empresas, visando à prospecção de novos } \\
\text { clientes. } \\
\text { Atuar no apoio administrativo, auxiliar na área } \\
\text { de gestão de pessoas e materiais, utilizando } \\
\text { ferramentas de informática. }\end{array}$ \\
\hline $\begin{array}{l}\text { 16. Transações } \\
\text { Imobiliárias }\end{array}$ & $\begin{array}{l}\text { Clientes, marketing, } \\
\text { negociação. } \\
\text { Vendas. }\end{array}$ & $\begin{array}{l}\text { Atuar com prospecção de clientes, elaboração } \\
\text { de proposta e negociação de valores. } \\
\text { Efetivar vendas. } \\
\text { Avaliar documentação. }\end{array}$ \\
\hline 17. Vendas & $\begin{array}{l}\text { Comunicação, produtos e } \\
\text { serviços, marketing, } \\
\text { empreendedorismo. } \\
\text { Clientes; } \quad \text { Vendas; } \\
\text { Orçamento. }\end{array}$ & $\begin{array}{l}\text { Atuar na prospecção de novos clientes, ativar } \\
\text { carteira de inativos. } \\
\text { Cadastrar clientes e vendas no sistema. } \\
\text { Atuar com atendimento, vendas e orçamentos. } \\
\text { Concretizar vendas. } \\
\text { Participação em eventos e feiras. } \\
\text { Elaborar relatórios de visitas. }\end{array}$ \\
\hline
\end{tabular}


Os resultados apontam que o mercado de trabalho exige que os profissionais técnicos do eixo Gestão e Negócios tenham conhecimento de informática (pacote Office), boa digitação, boa comunicação, técnicas de redação, empatia, capacidade de organização, iniciativa, relacionamento interpessoal/positivo para trabalhar em equipe.

Em diversos anúncios, mas especificamente para o técnico em comércio, comércio exterior, marketing, qualidade e vendas, o conhecimento de LE tem sido uma das exigências. As ações em LE, para esse eixo, referem-se ao atendimento ao público pessoalmente, por telefone, por e-mail e para lidar com rotinas administrativas.

Quadro 16 - Relação entre ação e finalidade

\begin{tabular}{|c|c|c|c|}
\hline Ação & & O que & Para \\
\hline $\begin{array}{l}\text { Atendimento ao } \\
\text { público }\end{array}$ & $\begin{array}{l}\text { Vendas } \\
\text { Negociação } \\
\text { Prestação de serviço } \\
\text { Fornecimento }\end{array}$ & $\begin{array}{l}\text { Produtos } \\
\text { Serviços } \\
\text { Informações } \\
\text { Dados }\end{array}$ & $\begin{array}{l}\text { Clientes } \\
\text { Fornecedores } \\
\text { Parceiros } \\
\text { Colaboradores } \\
\text { Consultores }\end{array}$ \\
\hline $\begin{array}{l}\text { Apoio administrativo } \\
\text { Organização } \\
\text { empresarial }\end{array}$ & $\begin{array}{l}\text { Organização } \\
\text { Controle } \\
\text { Avaliação } \\
\text { Prospecção }\end{array}$ & $\begin{array}{l}\text { Documentos } \\
\text { Pastas } \\
\text { Agenda } \\
\text { Contas } \\
\text { Mercadorias } \\
\text { Pessoal } \\
\text { Cliente } \\
\text { Contrato }\end{array}$ & $\begin{array}{l}\text { Relatórios } \\
\text { Planilhas } \\
\text { Reuniões } \\
\text { Pagamento } \\
\text { Estoque } \\
\text { Recrutamento } \\
\text { Cadastro }\end{array}$ \\
\hline
\end{tabular}

A participação social do sujeito no eixo gestão e negócio tem se revelado em três níveis nas seguintes relações: (1) empresa e profissional; (2) profissional e produtos/serviços e/ou atividades administrativas; (3) produtos e serviços e/ou atividades que possam atender a um público ou a procedimentos de organização empresarial e de apoio administrativo, executando as funções de rotinas administrativas, auxiliando na organização dos recursos humanos e materiais, bens, produtos e serviços, e utilizando ferramentas de informática.

Entre as possibilidades de cursos dentro do eixo tecnológico Gestão e Negócios, destacamos, nesta pesquisa, o técnico em Logística. Na próxima seção, detalharemos suas necessidades, levantadas por meio de entrevistas com profissionais da área.

\subsubsection{2 Área Específica: Logística}

$\mathrm{Na}$ área da Logística, as atividades de transporte, manutenção de estoques e processamento de pedidos são consideradas, normalmente, como atividades principais. Já 
outras atividades, como armazenagem, manuseio de materiais, embalagem, suprimento, planejamento e sistema de informação, são consideradas atividades de apoio, uma vez que dão suporte às atividades principais com o intuito de satisfazer e manter clientes.

Normalmente, os cargos para técnico em Logística são de analista/assistente e o que se busca do técnico em Logística é "a capacidade de planejar demandas, criar alternativas, atuar no controle das atividades de armazenagem e distribuição (...) conhecimento em informática (pacote Office) e boa digitação" (GUIMARÃES e BARÇANTE, op.cit., p. 10).

Para obter essas informações, por meio de entrevistas, nos guiamos por duas perguntas: uma com foco na rotina diária no ambiente de trabalho; e outra com o foco sobre o uso da LE nesse ambiente. Foi solicitado, primeiramente, que o profissional descrevesse sua rotina diária. Tivemos, como objetivo, selecionar os recortes comunicativos de suas atividades rotineiras e adaptá-los às situações de comunicação em LE, considerando o fato de que em algumas empresas a LE não é utilizada. As respostas das entrevistas semiestruturadas (apêndice H), codificadas e categorizadas, nos possibilitaram perceber as principais atividades desempenhadas pelo profissional no seu dia a dia. Entre as atividades, podemos ressaltar:

$\checkmark$ Compra e venda de produtos (entrada e saída de materiais)

$\checkmark$ Programação de cargas

$\checkmark$ Organização de entregas dos produtos

$\checkmark$ Acompanhamento dos resultados

$\checkmark$ Conferências de mercadorias na entrada e saída

$\checkmark$ Recebimento dos caminhões nas docas

$\checkmark$ Organização da mercadoria (cargas e descargas)

$\checkmark$ Armazenagens de itens: manutenção, estocagem e embalagem

$\checkmark$ Transporte de materiais

$\checkmark$ Definição de rotas de entregas das mercadorias

$\checkmark$ Controle e recebimento de notas

$\checkmark$ Recebimento e conferência de matérias primas e mercadorias

$\checkmark$ Descarte de matérias.

$\checkmark$ Preparação de relatórios, notas, carga e descarga, pedidos

$\checkmark$ Análise do estoque e das vendas; reposição de produtos; preços e cotações de preços

$\checkmark$ Análise do desempenho dos produtos quanto aos concorrentes, participação do mercado e outras coisas 
O uso da LE pode ser especialmente favorável em algumas atividades, como no processamento e no sistema de informação de pedidos (GUIMARÃES e BARÇANTE, 2015). Na gestão de compras, a sua importância recai nas próprias ações comunicativas que concorrem nesta atividade, desde o contato com fornecedores para compras de mercadorias, até a entrada dos produtos na empresa. Essa gestão de compras deve atender, ainda, às necessidades e exigências dos clientes, no que se refere à qualidade, à quantidade, aos prazos, aos custos, entre outros requisitos.

De forma pontual, solicitamos aos profissionais que destacassem as atividades comunicativas que são realizadas na LE no dia a dia da empresa, a fim de traçarmos possíveis tarefas em sala de aula.

As respostas das entrevistas possibilitaram, também, o levantamento das necessidades requisitadas pela área em relação ao uso da LE. Os seus dados parciais foram apresentados no IV Seminário Nacional de EPT (2014) e apontaram para os seguintes resultados:

Das 15 empresas pesquisadas, 13 utilizam a LE em contato direto com o cliente ou fornecedor por $e$-mail, telefone e face a face. Na triagem das documentações, leitura de embalagem; no armazenamento e conferências dos produtos; no controle interno de emissão de notas ou ordem de saída e recebimento de mercadorias. Das habilidades utilizadas, a compreensão escrita é utilizada em 11 das empresas pesquisadas, e as demais habilidades são utilizadas em 8 empresas, com clientes, fornecedores, presidente da empresa, marketing e motoristas (GUIMARÃES e BARÇANTE, 2015, p. 12)

Duas empresas (E1 e E5) não utilizam a LE em suas atividades diárias, porém acreditam que ela seja importante.

\footnotetext{
$\checkmark \quad$ Lemos, às vezes, mas raramente para ler algum artigo em algum site, internet (PE1).

Não usamos a língua estrangeira, nem espanhol, nem inglês (PE5).
}

O PE1 afirma que "ao passarem a exportar os produtos que comercializam, seria importante saber tanto o inglês como o espanhol”. Já o PE5 diz que "saber línguas abre portas para o mercado de trabalho".

Assim como o PE5, muitos dos profissionais entrevistados têm relacionado a importância da LE à ampliação de novas oportunidades no mercado de trabalho e acreditam, ainda, que saber, hoje, uma LE pode ser um fator de diferenciação profissional. Os excertos a seguir ilustram a opinião dos participantes a esse respeito: 


\begin{abstract}
$\checkmark \quad$ Acho importante saber línguas, abre portas para o mercado de trabalho.
$\checkmark \quad$ Acho que é importante para todo mundo e para um profissional então mais ainda, pois te diferencia, dá oportunidades.
\end{abstract}

Entretanto, para muitos, esse conhecimento está relacionado com a fluência e com a boa comunicação na língua.
$\checkmark \quad$ Acredito que, quando se tem o inglês fluente, as pessoas já te veem diferente.
$\checkmark \quad$ Acho que é preciso ser fluente se possivel, para falar ou escrever, pois trabalho em uma multinacional.

$\checkmark \quad$ A boa comunicação é de grande importância na área de trabalho.
$\checkmark \quad$ É importante ser fluente em alguma língua, principalmente o inglês.

Os profissionais PE4, PE6, PE8, PE11, PE13 afirmam que ser "fluente" é de suma importância e que saber uma língua adiciona valor na hora de uma contratação. O PE11 relata sua experiência nesse sentido:

$\checkmark$ Quando fui selecionado para trabalhar aqui, um dos requisitos era inglês e eu havia feito cursos rápidos e sabia o básico, talvez isso também tenha me favorecido (PE11).

Ainda em resultados parciais desse levantamento, foi observado por Guimarães e Barçante (2015) que, apesar do conhecimento de LE não ser um pré-requisito em algumas atividades cotidianas das empresas, algumas requerem naturalmente o seu uso, por exemplo, no atendimento ao cliente por telefone, aos motoristas, no fechamento de contrato, recepção e solicitação de mercadorias.

A partir da descrição do PE3, que trabalha em uma empresa que aluga móveis para embaixadas, entendemos que é necessário saber a língua para negociar e comercializar. Ao mencionar, por exemplo, que trocam informações com embaixadas, informando preços, prazos, condições da locação e por se tratar de uma empresa que trabalha com produtos específicos, inferimos que os profissionais precisam de uma competência de uso na LE, associada ao conhecimento técnico em nível de especificações dos produtos que estão sendo negociados para aluguel ou venda. O PE11 corrobora essa afirmação quando diz que "em reuniões com promotores, utilizamos vários termos técnicos em inglês, então não é saber só um pouco de comunicação, tem que saber falar alguns termos técnicos". 
A necessidade da aprendizagem da língua para lidar com situações comunicativas que requerem troca de informações entre vendedor/cliente com o uso de termos técnicos, foi apresentada também, por outras das empresas entrevistadas, como as empresas do ramo alimentício (E4, E5, E9, E13), da construção civil (E6, E8, E15), de produtos informáticos, de suporte técnico (E11 e E12) e de produtos hospitalares (E14). Apesar de E1 ser também de produtos alimentícios, não menciona situações que requerem interação com clientes e fornecedores.

Já a E2, que utiliza principalmente a LE na triagem e conferência de produtos, destaca a importância de saber comunicar-se e entender o mínimo da língua (inglês e espanhol), contudo não especifica o conhecimento técnico sobre um produto em particular. O PE2 ressalta a importância do profissional não ter somente conhecimentos para entender os documentos das mercadorias, mas competências mínimas para interagir verbalmente com os motoristas e a eles solicitar informações, algumas de cunho pessoal (como documentos, empresa em que trabalha, dados dos veículos) e outras mais específicas sobre prazos e condições das mercadorias.

O profissional do eixo Gestão e Negócios (e não somente da Logística) está em contato todos os dias com fornecedores e clientes, interagindo tanto pessoalmente quanto pelas demais formas de comunicação, e o conhecimento de LE pode facilitar a interação com diferentes fornecedores, além de estreitar parceiras. É somente por meio de uma parceria que as empresas conseguem negociar o volume de pedidos e satisfazer seus clientes, podendo, assim, o conhecimento da LE ser um fator determinante para uma boa colocação e (rel)ação profissional. Tal conhecimento também favorece e acelera o acesso às informações/conhecimentos produzidos, ampliação de horizontes sociais, culturais, educacionais e intelectuais.

Quanto à decisão sobre o que aprender, é necessário esclarecer que, por se tratar de contexto de ELFE para a formação profissional (não exclusivamente), há que se buscar o diálogo entre a instituição formadora e o mercado de trabalho, a fim de mapearmos "as necessidades e os interesses de uso de línguas estrangeiras que se apresentam para os tecnólogos e técnicos no exercício da profissão e pré-serviço, sem perdermos de vista a perspectiva educativa do processo de ensinar línguas" (BARÇANTE, texto online $e^{42}$ ). Isso posto, evidenciam-se a responsabilidade e necessidade de cooperação dos agentes envolvidos nesse processo.

\footnotetext{
${ }^{42}$ BARÇANTE, M. Programa de Pós-Graduação em Linguística Aplicada da Universidade de Brasília. Projeto de pesquisa. Disponível em:

$<$ http://www.pgla.unb.br/index.php?option=com_content\&view=article\&id=155:magali-

barcante - alvarenga\&catid=3:pesquisa\&Itemid=62 > Acesso em: 30/05/14.
} 
A partir do levantamento dos dados pelo procedimento de análise de objetivos (necessidades e interesses), foi possível definir temas e tarefas para o nosso planejamento CLIL para o ensino de ELFE na EPT de nível médio subsequente, bem como os elementos que o acompanham: atividades ou recortes comunicativos, funções comunicativas, realizações (expoentes linguísticos), que detalharemos na seção que segue.

\subsubsection{Seção C: Descrição do nosso planejamento CLIL por tarefas para o ELFE na EPT}

Ao tratarmos de planejamento de curso na EPT, é importante observar que temos, de maneira hierárquica, alguns tipos de planejamentos, sejam de caráter institucional, sejam pedagógicos. Consideramos como elemento dessa hierarquização o Projeto Político Pedagógico (PPP), o plano de curso, o plano de ensino do professor, e, por fim, o plano de aula e suas unidades. Isso quer dizer que, no planejamento de curso na EPT, concorrem abordagens no plano de gestão, colegiados e professores de línguas que, por sua vez, concorrem com abordagens de terceiros, como pais, alunos, materiais, outros professores de LE, etc.

O PPP está sedimentado na Lei de Diretrizes e Bases (LDB) 9394/96 de 20 de dezembro de 1996 e assume um papel de construção coletiva que abarca responsabilidade de todos os envolvidos. O artigo 12 da Lei 9394/96 define a incumbência dos estabelecimentos de ensino, dentre elas, elaborar e executar sua proposta pedagógica, e o artigo 13 trata da participação docente na elaboração do projeto pedagógico da escola e na organização de suas ações pedagógicas segundo a proposta pedagógica elucidada.

Em relação ao plano de curso, normalmente ele é construído por meio de um grupo pedagógico, colegiado de curso (em que concorrem abordagens) com professores da área técnica e é nesse nível que, normalmente, ocorre a decisão sobre a inserção do componente LE. Posto isso, é no plano de ensino e de aula que o professor de LE atua com maior flexibilidade e autonomia, sem desconsiderar os níveis anteriores. Explicitamos os tipos de planejamento, segundo o seu nível hierárquico, flexibilidade e concorrência de abordagens, na figura a seguir. 
Figura 14 - Tipos de planejamentos de caráter institucional e pedagógico

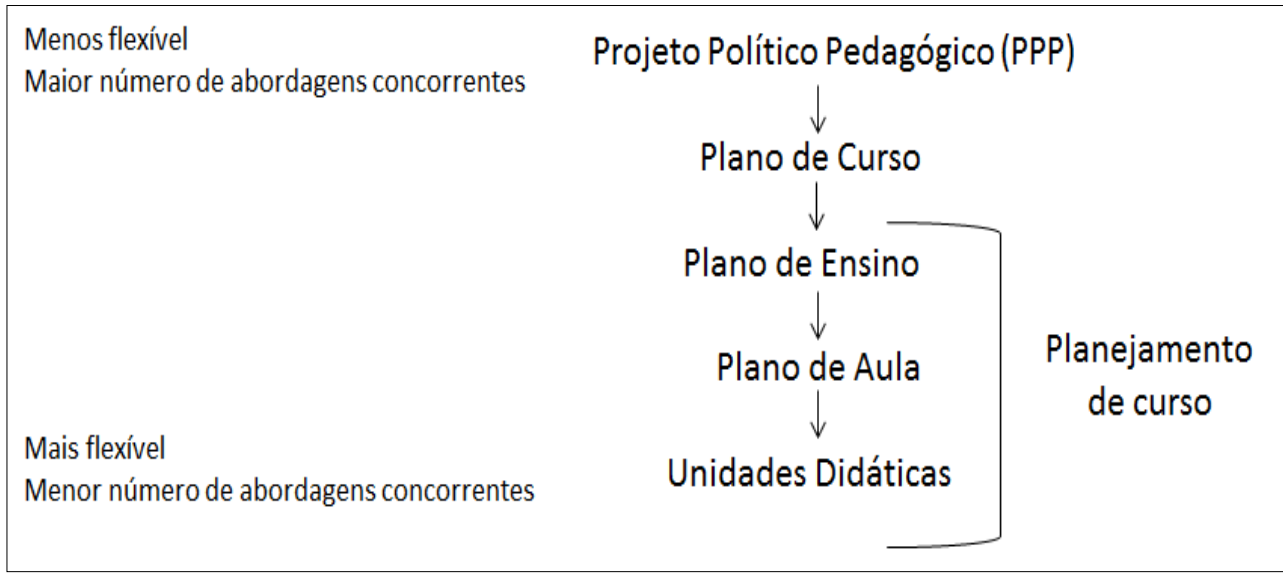

Fonte: Elaborado pela autora para tornar didática a informação

O planejamento de curso de LE encontra-se, portanto, a partir do nível do plano de ensino e nele normalmente concorrem abordagens do professor do componente LE, de outros professores de línguas (se houver), professores de outras áreas (construção interdisciplinar), materiais didáticos, entre outras. Para o nosso planejamento de curso, concorrem forças de terceiros (plano de curso e outros documentos da EPT).

Selecionamos do plano de curso do técnico em Logística do contexto pesquisado, os seguintes objetivos gerais que foram considerados para o planejamento em LE (IFB, 2010, p. 17):

$\checkmark$ Oferecer condições para que o estudante desenvolva as competências profissionais gerais requeridas pela área de Logística, de modo a facilitar e ampliar suas possibilidades de atuação e interação com outros profissionais;

$\checkmark$ Desenvolver as competências específicas relacionadas ao perfil de conclusão da habilitação de Técnico em Logística e das qualificações intermediárias que compõem seu itinerário profissional;

$\checkmark$ Proporcionar condições para formar profissionais éticos, que consigam atuar sob diferentes condições de trabalho, tomar decisões de forma responsável, para contornar problemas e enfrentar situações imprevistas, e que possam trabalhar em grupo de forma respeitosa e solidária.

O perfil que se pretende formar é, portanto, o de um "indivíduo responsável, criativo, crítico, diligente, prudente, pontual”, com espírito de liderança e participativo no processo de transformação da sociedade (IFB, op. cit., p. 19) “(...) Executará procedimentos relacionados a serviços ao cliente, transporte, manutenção de estoques, processamento de pedidos, 
armazenagem, manuseio dos materiais, compras, embalagens, programação de produção e manutenção de informações".

Nesse percurso profissional, nos perguntamos de que forma o ensino de LE pode contribuir para o desenvolvimento de "competências para a laborabilidade e formação geral e específica (competência profissionais gerais - comuns de cada área e profissionais específicas de cada qualificação ou habilitação)" e uma formação cidadã?

Para tanto, consideramos para o nosso planejamento de LE duas bases significativas Língua(gem)/Trabalho e Sociedade/Trabalho. Trata-se da inte(relação) entre o mundo do trabalho, cultura, desenvolvimento científico-tecnológico e língua(gem). LE no sentido dos valores estéticos, políticos e éticos postos pela sociedade.

O aluno foi levado a expressar (em LE) seus conhecimentos, valores e atitudes sobre práticas sociais, culturais relacionadas ao trabalho, e sociedade por meio de reflexões em grupo e em atividades integradoras, conforme proposto por Moura (2012, p. 14). As atividades versavam sobre várias estratégias/temáticas que incluem a problemática do trabalho e as demais dimensões (ciência, tecnologia e cultura) "a partir das relações entre situações reais existentes nas práticas sociais concretas (ou simulações) e os conteúdos das disciplinas". A sala de aula é, nessa perspectiva, um espaço integrador, em que funciona como meio da simultaneidade Língua(gem)/Trabalho e Sociedade/Trabalho, podendo ser possível atender às necessidades dos alunos, do mundo do trabalho e da sociedade e desenvolvendo competências gerais e específicas.

Conforme dissemos anteriormente, buscamos, neste planejamento, a partir da combinação entre conteúdo/temas e tarefas, mobilizar os conhecimentos, os significados, as atitudes e os valores para desenvolver uma CC capaz de levar os alunos a integrarem-se socialmente (pessoal e profissionalmente) no mundo, por meio da reflexão e da ação. Para a sistematização do planejamento CLIL por tarefas, nos baseamos nas propostas combinadas de Estaire e Zanón (1990) e de Almeida Filho (2012), para o delineamento de unidades didáticas.

Como exemplo para a organização de uma unidade temática, imaginemos, portanto, o seguinte recorte comunicativo, que são práticas sociais de uso da L-alvo, de uma situação de atendimento ao cliente: "Interagir com o cliente por e-mail, transmitindo informações simples sobre um produto, tirando dúvidas, de acordo com os critérios de redação (estrutura, formato, convenções) desse gênero textual". Outros recortes aparecem na situação de atendimento ao cliente, no entanto, para ilustrar nosso planejamento, utilizaremos apenas esse. O quadro a seguir (quadro 18) apresenta a estrutura utilizada para o planejamento de curso neste trabalho. 
Quadro 17 - Estrutura das Unidades Temáticas para este trabalho

\section{Descrição do contexto maior: definição do contexto e antecedentes}

- Dados dos alunos.

- História do curso.

- Legislação que regulamente o nível ou modalidade que se ensina (critérios, princípios para a elaboração do curso, carga horária, etc.): identidade dos perfis profissionais de conclusão de curso, independência e articulação com o Ensino Médio.

* Contexto Educacional: Educação Profissional de nível médio subsequente em Logística do eixo Gestão e Negócios do IFB, curso noturno.

\section{Justificativa para aprender uma LE:}

- Objetivos linguísticos, educacionais, psicológicos, culturais e práticos.

* Relevância do uso da L-alvo na contemporaneidade, desenvolvimento de competências para a laborabilidade, respeito aos valores estéticos, políticos e éticos, flexibilidade, interdisciplinaridade e contextualização; atendimento às demandas dos cidadãos, do mercado e da sociedade; desenvolvimento de competências básicas, constituídas no Ensino Fundamental e Médio; competências profissionais gerais, comuns aos técnicos de cada área; competências profissionais específicas de cada qualificação ou habilitação.

\section{Condições de implementação do planejamento:}

* autonomia da escola em seu projeto pedagógico, atualização permanente dos cursos e currículos, conciliação das demandas identificadas com a vocação e a capacidade institucional da escola ou da rede de ensino.

4. Tipo de curso: Definido a partir do contexto educacional (mencionando acima) e pelo levantamento de objetivos dos alunos e da situação-alvo.

* Para fins específicos, para formação profissional, para negócios.

\section{Análise de objetivos}

Quais são as necessidades e interesses dos alunos? Específica para cada contexto. Pode ser levantada por meio de questionário, conversa informal etc.

\section{Quais as necessidades da situação-alvo?}

Situação comunicativa ${ }^{43}$ :

- contexto (âmbito de uso): segundo as informações explicitadas no catálogo de cursos técnicos, o profissional desse eixo tem, como possibilidade, atuar em instituições públicas, privadas e do terceiro setor, indústria e comércio, bancos e corretoras de câmbio, empresas de consultoria e, ainda, de forma autônoma, escritórios, cooperativas, empresas de administração de algum

\footnotetext{
${ }^{43}$ Uma situação comunicativa se compõe de dois fatores: um contexto e as interações pessoais que estão condicionadas pelo contexto. Em cada situação comunicativa, é possível definir os participantes, canal de comunicação, código, relações espaciais entre sujeito e objeto, postura, gestos, tema, forma da mensagem (debate, conversa, conferencias) e o tipo de discurso e gênero (BELTRÁN, 2012).
} 
serviço ou produto, departamentos administrativos de empresas privadas e de instituições públicas.

- Interações: rotinas administrativas, atendimento ao público, situação de compra e venda.

- Tipos de agir nas interações: estratégico/instrumental e/ou comunicativo.

- participantes: clientes, fornecedores, parceiros, colaboradores, consultores, funcionários ${ }^{44}$.

- número de participantes: singular, dual, plural?

- Canal de comunicação: pessoalmente, por telefone, por e-mail.

5. Níveis ou ciclos: Nível 1 (1 módulo semestral de 40h/a)

6. Tipos de planejamento: planejamento cíclico, com pré-seleção de unidades de curso, sem uma progressão rigorosa, e sim um sentido flexível para a possibilidade de expansão ou modificações segundo as necessidades e os interesses dos alunos.

7. Replanejamento: Houve a necessidade de reformulação do plano de ensino.

8. Taxinomia: Sistematização do planejamento CLIL por tarefas

A. Escolha do tema e tópicos/áreas de interesse - a partir da análise de objetivos.

B. Especificação de objetivos - a partir da análise de objetivos, é possível definir as atividades ou recortes comunicativos, por exemplo, tirar as dúvidas dos clientes sobre produtos por $e$ mail $^{45}$. Os recortes desta pesquisa foram delimitamos por ações (comuns entre as áreas do mesmo eixo e também da área específica do curso).

- quais são as possíveis ações práticas (habilidades) para esse recorte?

Em um recorte, as habilidades são integradas, no entanto é necessário observar qual será trabalhada em maior ou menor proporção em determinada tarefa.

Figura 15 - Habilidades integradas com destaque para a de maior ou menor proporção

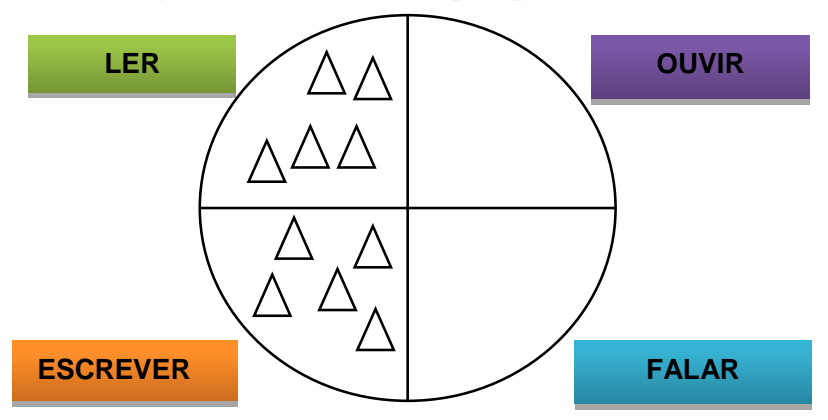

Fonte: Elaborado pela autora

Objetivos: Relação entre Sociedade/Trabalho (Refletir) e Língua(gem)/Trabalho(Participar):

\footnotetext{
${ }^{44}$ Participantes definidos por meio das ofertas de emprego.

${ }^{45}$ Este recorte foi definido a partir da análise de oferta de trabalho para o técnico em Marketing.
} 
- $\underline{\text { Refletir }}$ sobre a importância de ser direto, cordial e honesto na oferta de produtos, de mercadoria, e de bens ou serviços.

- Participar de situações de atendimento ao cliente por e-mail, transmitindo informações simples sobre um produto, tirando dúvidas, de acordo com os critérios de redação (estrutura, formato, convenções) desse gênero textual.

C. Programação da Tarefa Final (TF) - demostram o cumprimento dos objetivos. Em um planejamento CLIL, as tarefas são similares ao que as pessoas (e profissionais - ELFE) fazem na vida real com a língua(gem) em relação ao tema e área de interesse.

Os alunos refletem acerca da importância de serem diretos, cordiais e honestos na oferta de produtos, de mercadoria, e de bens ou serviços -> discutem sobre diferentes possibilidades de interagir com o cliente por escrito $->$ buscam modelos de $e$-mails, cartas ou fax-> realizam atividades relacionadas à estrutura, ao formato de um $e$-mail-> Escrevem um $e$-mail para um cliente respondendo as suas dúvidas quanto a um determinando produto, descrevendo as suas vantagens produto de maneira clara e breve.

D. Planejamento do processo - programação das tarefas possibilitadoras (TAL) e tarefas comunicativas (TC), necessárias para a execução das tarefas finais - insumo para as ações.

Funções comunicativas - para o cumprimento das ações interligadas ao recorte comunicativo.

- Que tipos de funções são necessários para o cumprimento desse recorte?

Interpretar e responder as dúvidas do cliente no padrão pergunta-respostas.

Realizações (expoentes linguísticos) - necessárias para materialização das funções.

- Quais expoentes linguísticos são necessários para o cumprimento dessa função?

Realizações (expoentes linguísticos): Estimado Sr (Nombre). En nuestra empresa llevamos más de 10 años (...)

As funções e realizações foram definidas com base no Plano curricular do Instituto Cervantes ${ }^{46}$ - Níveis de referência para o espanhol (PCIC). Apesar do PCIC ser dividido em níveis de referências para pelo $\mathrm{MCER}^{47}$, consideramos, para o ELFE, referências de acordo com as necessidades e interesses.

Especificação de componentes linguísticos (gramática, léxico, fonética) - decorrentes do uso e a ele subordinado.

- Quais elementos linguísticos são necessários para o cumprimento das tarefas?

\footnotetext{
${ }^{46}$ Plan curricular del Instituto Cervantes (PCIC) - Publicado en tres tomos que suman un total de 2.000 páginas, el Plan curricular desarrolla y fija los niveles de referencia para el español según las recomendaciones que propuso el Consejo de Europa en el año 2001. http://www.cervantes.es/lengua_y_ensenanza/aprender_espanol/plan_curricular_instituto_cervantes.htm

${ }^{47}$ Consejo de Europa (2001), Marco común europeo de referencia para las lenguas: aprendizaje, enseñanza, evaluación, Madrid, Secretaría General Técnica del MEC, Anaya e Instituto Cervantes, 2002. O Quadro Europeu Comum de Referência para as Línguas divide o conhecimento dos alunos em três categorias, cada uma com duas subdivisões: A-Falante básico (A1 Iniciante/A2 Básico), B-Falante independente (B1 Intermediário/B2 Usuário independente), C-Falante proficiente (C1 Proficiência operativa eficaz/C2 Domínio pleno). Disponível em:

http://pt.wikipedia.org/wiki/Quadro_Europeu_Comum_de_Refer\%C3\%AAncia_para_as_L\%C3\%ADnguas.

Acesso em 10 jun. 2014
} 
Descrever a gramática, vocabulário, elementos culturais que serão necessários para desenvolvem-se durante a tarefa. Conhecimentos de mundo (como se portar com o cliente, diferenças culturais).

Os recortes comunicativos são materializados em forma de tarefas, com negociação de significados, interações que possam chegar a um produto final. Por exemplo: produzir "uma mensagem eletrônica descrevendo as vantagens de determinado produto", ação que requer também a produção de tarefas possibilitadoras, que atuam como suporte para as ações comunicativas, uma vez que seu objetivo é o de propiciar aos alunos os instrumentos linguísticos necessários. Ou seja, possibilitam linguisticamente (ESTAIRE, 1990) a realização das tarefas comunicativas com o objetivo de alcançar o produto final na TF. E é, nas tarefas possibilitadoras, que os elementos linguísticos passam a ser apresentados, dado que eles, neste tipo de planejamento, não são descartados (ALMEIDA FILHO, 2013).

Além disso, será necessário mobilizar alguns valores e atitudes, como ser claro, breve e honesto caso o produto não atenda às necessidades do cliente, ou, ainda, caso não seja possível ajudá-lo, oferecer alternativas. Sendo assim, saber-fazer, que é uma dimensão prática do conhecimento, precisa também de atitudes. Discutir em sala de aula as experiências e percepções pode contribuir para o desenvolvimento de uma reflexibilidade ${ }^{48}$, que pode ser caracterizada por novas ações e atitudes após a reflexão. O professor de LE poderá contribuir com essa mobilização trazendo diferentes formas de insumos (filmes, propagandas, notícias, música, vídeos) que possam motivar discussões em sala de aula sobre, por exemplo, a importância de ser direto e cordial na oferta de produtos, de mercadoria, e de bens ou serviços.

Em um recorte comunicativo, é possível perceber várias ações simultaneamente. Sendo assim, as ações estão para os recortes assim como as habilidades, conhecimentos, atitudes e valores estão para as competências. Entendemos que, no catálogo de cursos técnicos e nas ofertas de trabalho, o "agir" do profissional é tratado em nível de habilidades "saber-fazer", podendo ser materializadas em funções (como fazer?), por exemplo: o profissional, segundo a oferta de trabalho, precisa “descrever produtos, serviços, materiais e bens" e, para descrevê-los (funções), usam realizações (expoentes linguísticos) e mobilizam além das ações, atitudes, conhecimento que detém sobre o assunto.

Para que os alunos possam desempenhar, por meio das tarefas em sala de aula, as ações requisitadas pela situação-alvo em relação a LE, além de competência de uso da língua, foram

\footnotetext{
${ }^{48}$ ALVARÉZ, Maria Luisa Ortiz - Notas de Aula da Disciplina Competência Comunicativa do Programa de Pós Graduação em Linguística Aplicada da Unidade de Brasília. Brasília: Universidade de Brasília - 06/11/2012
} 
mobilizadas competências gerais: conhecimento declarativo, habilidades, existenciais e de aprender (MCER). Foram considerados, portanto, o conhecimento de mundo dos alunos, a partir das suas experiências prévias, das fontes de informações, de acontecimentos; conhecimento quanto às relações interpessoais no cotidiano e no ambiente de trabalho; conhecimento sobre convenções sociais; comportamento em várias situações de trabalho; além dos valores sociocultural e intercultural ${ }^{49}$, das relações sociais e atitudes, entre outros.

As tarefas de refletir, expressar opiniões, atitudes e conhecimentos sobre determinada temática, seguem um fluxo iniciado em dar opinião, na Unidade 1, tendo o grau de complexibilidade aumentado conforme o transcorrer das demais unidades, conforme explicitamos a seguir:

\author{
Nível 1 \\ Dar opinião \\ Nível 2 \\ Expressar acordo ou desacordo \\ Valorar \\ Nível 3 \\ Expressar certeza e evidência \\ Expressar possibilidades \\ Nível 4 \\ Expressar obrigação e necessidade
}

São ações que necessitam, além do conhecimento declarativo, da capacidade de usar conhecimento dos elementos linguísticos, dos expoentes diretos das funções comunicativas, das desenvolturas discursivas, das estratégicas sociocontextuais e, principalmente, dos fatores não verbais, como a linguagem corporal, o silêncio e os contatos visuais com o público.

Para o desenvolvimento de "ações gerais" de cunho científico-tecnológico, pesquisar na internet e elaborar slides foram considerados conhecimentos das TICs. Para o nosso planejamento, utilizamos as TICs (CHURCHES, 2009) como ferramenta para compreender

\footnotetext{
${ }^{49}$ A competência intercultural, segundo o MRCE (2002), é o conhecimento, a percepção e a compreensão da entre ente o "mundo de origem" e o "mundo da comunidade objeto de estudo" que incluem a consciência das diversidades e um olhar sobre os estereótipos que são criados de determinada comunidade escolar. Entendemos, ainda, a competência intercultural como a capacidade de lidarmos com pessoas de diferentes culturas, ter uma postura de abertura, curiosidade, humildade e flexibilidade. Sabendo se distanciar de estereótipos que são criados por crenças.
} 
(interpretar, resumir, inferir, classificar, comparar, exemplificar, etc.), analisar (comparar, organizar, encontrar, estruturar, integrar) e recordar (reconhecer, listar, descrever, identificar, localizar, etc.) informações do conteúdo do eixo e da área em buscadores. Salientamos, ainda, que podem ser fomentados outros tipos de troca num processo de interação, como a criação de blog, website, participação em redes sociais, entre outros. Entre algumas dessas atividades, trabalhamos com o envio de currículo por e-mail, respondendo a uma oferta de emprego e contanto com fornecedores/expositores por e-mail (simulação entre eles).

Integrar as ações de uso da língua é estabelecer o seu uso social que, por sua vez, está relacionada aos objetivos (necessidades e interesses) dos alunos e/ou da situação em que atuará socialmente nesta língua (em seu cotidiano pessoal e profissional), estabelecendo, assim, as competências a serem desenvolvidas. Por isso, o modelo de CC é definido segundo os objetivos (as ações) que se busca alcançar.

Consideramos o desenvolvimento da CC e FI sob a perspectiva de duas ações: a ação comunicativa e estratégica/instrumental (HABERMAS, 2012). Parece-nos pertinente uma correlação entre a linguagem em Habermas e o processo de ensino e aprendizagem de línguas na EPT técnica de nível médio subsequente, do eixo Gestão e Negócios, uma vez que, nesse tipo de contexto, nos deparamos, normalmente, com uso de língua(gem) voltado para situações de comunicação (cotidiano organizacional de uma empresa). Tais situações são caracterizadas por ações sociais baseadas nas interações entre profissionais, direção/gestores/empregados, e clientes, fornecedores, financiadores, ou a comunidade que, ao mesmo tempo em que detêm recursos (produtos e serviços) em situações coordenadas e interações "previsíveis", neste caso um agir estratégico/ instrumental.

As empresas produzem produtos ou serviços e, nelas, as pessoas interagem, tomam decisões e agem estratégica ou instrumentalmente. Apesar do conceito de ação estratégica ter uma carga negativa, trazendo a ideia de ação utilitarista, de manipulação com regras monológicas de ação, consideramos que tal atitude, concebida a partir da interpretação de uma dada situação, permite uma decisão entre ação estratégica/instrumental (êxito, finalidade) ou comunicativa (baseadas em entendimento). Entretanto, com esta ferramenta "saber-fazer", o uso da língua(gem) instrumental se cobre, muitas vezes, de uma imagem confiante e crível no controle da mensagem e do conhecimento que detém sobre o produto e o serviço que oferece, e, nele, os valores éticos, políticos e estéticos devem ser considerados.

Não estamos reconhecendo apenas a presença da comunicação como instrumento funcional da ação instrumental, mas admitindo, também, a presença do agir comunicativo nas relações interpessoais entre empresas e clientes. Sendo assim, o agir comunicativo ultrapassa a 
interação entre duas pessoas de forma "previsível", se trata, aqui, de uma interação ampla, interação entre pessoas e a interação de pessoas com o mundo, sendo esse agir fundamental para a compreensão das relações sociais. Utilizamos esse agir quando questionamos, por exemplo, nosso direito de consumidor, buscando encontrar uma via de entendimento.

É o agir comunicativo que potencializa, no ser humano, sua capacidade e iniciativa para dirigir suas próprias vidas com autonomia. É esse agir que, no construto teórico de Habermas (2012), oferece possibilidade para a integração social. Sendo assim, para o ensino de LE na EPT no curso técnico do eixo Gestão e Negócios, passamos a considerar o ensino da língua(gem) para o agir estratégico-comunicativo, tendo em mente a ideia de uma ação que cumpre duas finalidades simultaneamente.

Tomando como base essa duas ações para a língua(gem), utilizamos, para o nosso estudo, o modelo de CC de Celce-Murcia (2007), uma vez que é comum em cursos, principalmente aqueles voltados para o contato direto com o público, a busca em desenvolver uma competência formulaica, devido a maior parte das tarefas comunicativas dentro desse contexto envolverem funções linguísticas próprias deste tipo de comunicação, como: cumprimentar, despedir-se, agradecer, oferecer ajuda, informar, etc. Algumas funções comunicativas ocorrem repetidas vezes em situações previsíveis e recorrentes, em que os fatores sociocontextuais (idade, gênero, status, distância social, relações de poder e afetivas) ditam as regras da língua e do discurso. Apesar de considerarmos que a competência formulaica não promove uma competência de agir livre e não contribui para a capacidade de aprendizagem consciente e criativa, ela promove o aumento da habilidade comunicativa do aluno e faz parte de um agir instrumental.

O ambiente de trabalho favorece, também, a comunicação interacional - capacidade de colocar-se em comunicação com outros - seja ela oral, seja por escrito. A competência interacional envolve tomada de turnos que possibilita monitorar a fala de acordo com as necessidades e o contexto do discursivo, porém, muitas vezes em contexto profissional, a comunicação interacional limita-se a cumprimentos, despedidas e agradecimentos (competência formulaica) e são ditadas pelos fatores sociocontextuais e culturais.

É, portanto, por meio dos recortes comunicativos que definimos os objetivos do curso, as competências e habilidades a serem desenvolvidas, o nosso modelo de CC e a taxonomia do curso. A taxonomia define as unidades didáticas, que, por sua vez, se compõem em um planejamento CLIL por tarefas no conteúdo/tema que será trabalhado, nos objetivos da relação língua(gem)/sociedade/trabalho que seriam atendidos, culminando em uma tarefa final (TF) que, para a sua efetivação, são necessárias tarefas comunicativas (TC) de interação, negociação 
do significado, vazio de informação em grupo e, também, tarefas possibilitadoras (TAL) (atividades, propriamente ditas).

Foram definidos, assim, quatro temas centrais e dois tópicos para cada tema, formando unidades temáticas, envolvendo as relações entre:

Empresa: sua organização e estrutura, por ser o local onde atua o profissional.

O profissional: a relação entre empresa e o perfil profissional.

Mercados: a relação do profissional e produtos e serviços que oferece.

Comunicação: a relação da empresa e do profissional no atendimento ao público e nas rotinas administrativas.

O quadro a seguir especifica o nosso cronograma, composto pela carga horária destinada ao cumprimento de cada unidade e o número de aulas necessárias, os temas, tópicos e os objetivos de cada unidade. Os objetivos, assim postos, referem-se aos recortes comunicativos, quer dizer às práticas sociais simultâneas da relação entre Lingua(gem)/Trabalho e Sociedade/Trabalho (conteúdos/temas e língua), sempre em nível de reflexão e de participação em situações comunicativas no âmbito do trabalho.

Quadro 18 - Configuração das Unidades Temáticas: temas, tópicos, objetivos

\begin{tabular}{|c|c|c|c|c|}
\hline $\begin{array}{c}\text { Aul } \\
\mathbf{a}\end{array}$ & Tema & Tópicos & $\begin{array}{c}\text { Objetivos } \\
\text { Sociedade/Trabalho (ST) e } \\
\text { Língua(gem)/Trabalho (LT) }\end{array}$ & $\begin{array}{r}\text { CH } \\
\text { H/A }\end{array}$ \\
\hline 1 & \multirow[b]{3}{*}{ EMPRESA } & Ideia de & \multirow{3}{*}{ 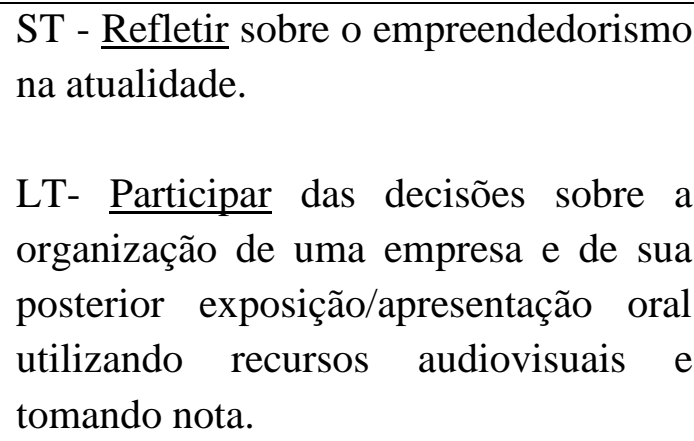 } & \multirow[b]{3}{*}{12} \\
\hline 2 & & Negócio & & \\
\hline 3 & & $\begin{array}{l}\text { Organização } \\
\text { empresarial }\end{array}$ & & \\
\hline 4 & \multirow[b]{3}{*}{$\begin{array}{c}\text { O } \\
\text { PROFISSIONAL }\end{array}$} & Perfil & \multirow{2}{*}{ 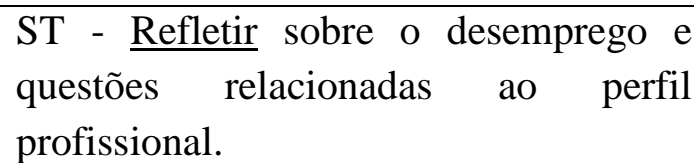 } & \multirow[b]{3}{*}{8} \\
\hline 5 & & & & \\
\hline & & Recrutamento & $\begin{array}{l}\text { LT - Participar da seleção e/ou } \\
\text { solicitação de trabalho explicando } \\
\text { experiências e formação e } \\
\text { compreendendo as especificações de um } \\
\text { perfil profissional. }\end{array}$ & \\
\hline
\end{tabular}




\begin{tabular}{|c|c|c|c|c|}
\hline 6 & \multirow[b]{2}{*}{ MERCADOS } & $\begin{array}{c}\text { Produtos e } \\
\text { servicos }\end{array}$ & \multirow{2}{*}{$\begin{array}{l}\text { ST - Refletir sobre o "comércio justo" e } \\
\text { o consumo consciente. } \\
\text { LT - Participar de reuniões e conversas } \\
\text { com colegas de trabalho sobre produtos, } \\
\text { catálogos, ofertas e orientações para sua } \\
\text { divulgação em uma feira. }\end{array}$} & \multirow[b]{2}{*}{8} \\
\hline 7 & & Mercadotecnia & & \\
\hline 8 & & $\begin{array}{c}\text { Clientes e } \\
\text { fornecedores }\end{array}$ & $\begin{array}{l}\text { ST - } \underline{\text { Refletir }} \text { sobre formas } \\
\text { comercialização e negociação em } \\
\text { diferentes culturas e da relação } \\
\text { interpessoal entre clientes e fornecedores }\end{array}$ & \\
\hline 10 & COMUNICAÇÃO & $\begin{array}{l}\text { Documentos, } \\
\text { Logística e } \\
\text { transporte }\end{array}$ & $\begin{array}{l}\text { (enganos, persuasão, bom atendimento). } \\
\text { LT - Participar de uma conversação } \\
\text { entre cliente e fornecedores (entre } 2 \text { ou } \\
\text { mais pessoas) pessoalmente, por e-mail e } \\
\text { por telefone parar tratar sobre solicitação } \\
\text { de pedidos, lendo documentos, } \\
\text { informando prazos e condições de } \\
\text { transporte. }\end{array}$ & 12 \\
\hline
\end{tabular}

A primeira unidade temática refere-se à organização de uma empresa, desde a sua criação, concepção, ideia de negócio, viabilidade com estudo de mercado (análise $S w o t^{50}$ ) e a sua estrutura organizacional (organograma).

Para essa unidade, foram definidos, portanto, dois tópicos importantes: a ideia de negócio e a organização empresarial, e, como recorte comunicativo para Língua(gem)/Trabalho (LT), "Participar das decisões sobre a organização de uma empresa e de sua posterior exposição/apresentação oral utilizando recursos audiovisuais e tomando nota.". Para alcançar esse objetivo, foram levantadas, incialmente, reflexões sobre "empreender em tempo de crises" atendendo à articulação do recorte para LT, e recorte para Sociedade/Trabalho (ST), que é "Refletir sobre o empreendedorismo na atualidade", materializadas em sala de aula na seguinte tarefa final (TF).

\footnotetext{
${ }^{50} \mathrm{O}$ termo SWOT é uma sigla oriunda do idioma inglês, e é um acrónimo de Forças (Strengths), Fraquezas (Weaknesses), Oportunidades (Opportunities) e Ameaças (Threats). É é uma ferramenta utilizada para fazer análise de cenário (ou análise de ambiente), sendo usada como base para gestão e planejamento estratégico de uma corporação ou empresa. https://pt.wikipedia.org/wiki/An\%C3\%A1lise_SWOT
} 
Os alunos refletem sobre empreender em tempo de crises -> Cada grupo cria uma empresa -> Os grupos apresentam oralmente "a empresa" para o grande grupo utilizando recursos audiovisuais -> "O público" (o grande grupo) toma nota, faz perguntas e completa um questionário previamente selecionado.

Para o cumprimento da TF, foram consideradas as seguintes ações (TC e/ou TAL):

Ação 1 - Expressar opiniões sobre empreender em tempo de crises, a partir da leitura de notícias relacionadas a essa temática.

Ações 2 e 3 - Buscar e selecionar informações na internet - tipos de empresa, análise Swot, organograma.

Ações 4 e 5- Organizar as informações selecionadas para a criação de uma empresa e preparar slides para apresentá-la oralmente.

Ações 6 - Expor informações sobre a empresa, observando fatores discursivos, estratégicos e não verbais em uma apresentação oral.

Ações 7, 8, 9 e 10 - Compreender, de forma global, as informações detalhadas nas apresentais orais e tomar nota no transcurso da apresentação, interagir para obter informações sobre a empresa a fim de completar um quadro.

As ações práticas para esse recorte, que foram a de manipular informações e prepará-las para a apresentação, teve o foco na leitura, na interpretação de informações e na escrita.

Para esse procedimento, é necessário que os alunos possuam conhecimento digitais e tecnológicos, para manipular pesquisa na internet, buscar desenhos (organogramas) e preparar os slides. Estruturar o discurso presencialmente, dar informações sobre a empresa (objetivos, análise Swot e sobre a sua estrutura organizacional), teve o foco na produção oral em maior proporção; além disso, os alunos, ao tomarem notas, pedirem informações para completar dados das empresas apresentadas, tiveram como foco a compreensão oral. Ainda que ouvir e falar tenham tido maior relevância no produto final da tarefa, houve integração das habilidades (ações) no recorte selecionado durante as atividades de manipulação, troca e seleção das informações. Além disso, o aluno, ao ser o expositor e ao mesmo tempo o ouvinte, utiliza as habilidades de ouvir e falar de forma equilibrada, assim como as de ler (os slides das apresentações) e completar (escrevendo) na folha das atividades as informações dos demais grupos. 
Figura 16 - Habilidades integradas na Unidade 1 - destaque para a de maior ou menor proporção

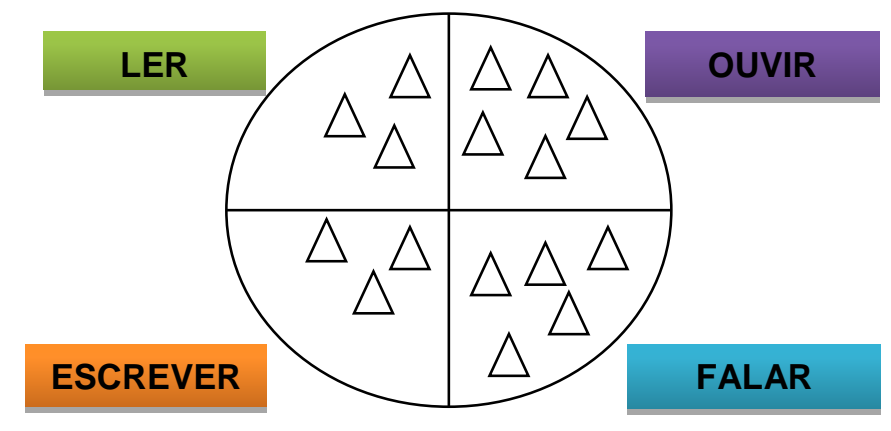

Para a unidade 2 (O profissional), foram definidos dois tópicos: o perfil e recursos humanos e, como recortes comunicativos para LT, "Participar da seleção e/ou solicitação de trabalho explicando experiências e formação e compreendendo as especificações de um perfil profissional". Para alcançar esses objetivos, foram levantadas incialmente reflexões sobre "o desemprego e as características do perfil de um bom profissional", atendendo à articulação do da LT e ST que é "Refletir sobre o desemprego e questões relacionadas ao perfil profissional", materializadas na seguinte TF:

Os alunos refletem sobre o desemprego e sobre as características do perfil de um bom profissional -> Preparam um decálogo do bom profissional em grande grupo -> Cada grupo discute sobre o perfil do profissional que busca para ocupar "determinado" cargo préselecionado dentro da empresa e prepara anúncios de oferta de emprego-> Os grupos apresentam e exibem em um "mural" os anúncios elaborados-> Os demais grupos tomam notas das exigências e prepararam um currículo sob medida $\rightarrow$ Os grupos participam de uma simulação de entrevista explicando experiências e formação e compreendendo as especificações de um perfil profissional, por meio de perguntas aleatórias.

Para o cumprimento da TF foram consideradas as seguintes ações:

Ação 1 - Expressar acordo e desacordo sobre questões relacionadas ao desemprego e sobre o perfil profissional, a partir da leitura de notícias relacionadas a essa temática.

Ação 2 e 3 - Selecionar informações para listar características de um bom profissional a partir da descrição dos atributos dos personagens do filme que assistiram e a partir da descrição individual que cada aluno fez sobre si mesmo. 
Ação 4 e 5 - Preparar e expor um anúncio de oferta de emprego para um posto específico dentro da empresa, a partir de outros modelos de anúncios levantados na internet e dos modelos apresentados em sala pelo professor.

Ação 6 e 7 - Preparar currículo utilizando o Word e enviar por e-mail respondendo a um anúncio de oferta de trabalho.

Ação 8 - Participar de uma simulação de entrevista fazendo perguntas aleatórias.

As ações práticas para esse recorte foram a de selecionar informações para definir o perfil de um bom profissional, compreender informações em anúncios de emprego e em currículos (foco na compreensão escrita), preparar anúncio e currículo (foco na produção escrita) e, ao participar da entrevista de trabalho em grupo, o foco recai na produção oral. Ainda que ler e escrever tenham tido maior relevância para o desenvolvimento da TF, o seu produto final, que consistiu em participar da seleção e/ou solicitação de trabalho, teve as habilidades de ouvir e falar em maior destaque.

Figura 17 - Habilidades integradas na Unidade 2 - destaque para a de maior ou menor proporção

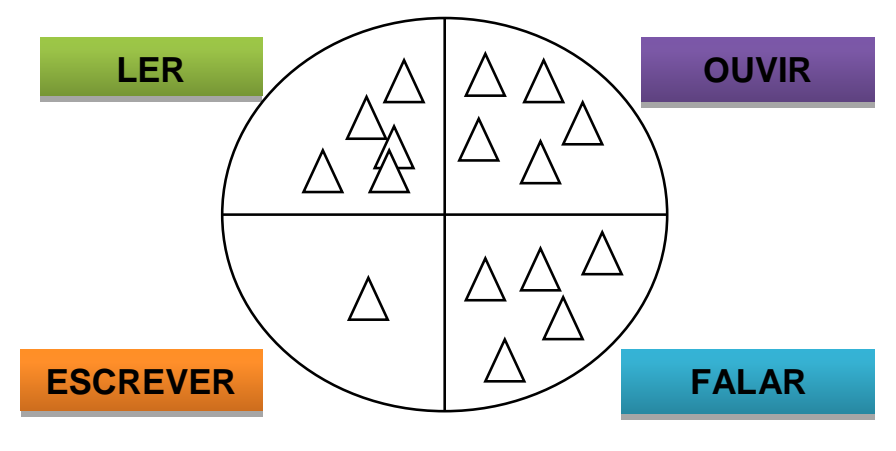

Para a unidade 3 (Mercados), foram definidos dois tópicos: produtos e serviços e mercadotecnia e, como recortes comunicativos LT, "Participar da preparação de produtos, catálogos, ofertas e orientações para sua divulgação em uma feira”. Para alcançar esses objetivos, foram levantadas, incialmente, reflexões sobre "consumo consciente" atendendo à articulação para LT e ST que é "Refletir sobre o consumo", materializadas em sala de aula na seguinte TF: 
Os alunos refletem sobre consumo consciente-> Cada grupo prepara o plano de marketing de sua empresa (tipos de produtos, preços, descontos etc.) -> Elabora um folheto sobre a empresa e seus produtos -> Apresenta ao grande grupo.

Para o cumprimento da TF foram consideradas as seguintes ações:

Ação 1 - Expressar certeza, evidências e possibilidades sobre questões relacionadas ao comércio justo e sobre o consumo.

Ação 2 e 3 - Buscar e selecionar informações sobre produtos para preparar um plano de marketing (tipo de produtos, preço, descontos) dos produtos que irão expor na feira.

Ação 4 - Criar um folheto sobre a empresa e seus produtos.

Ação 5 - Apresentar o folheto ao grupo.

As ações práticas para esse recorte foram de selecionar informações para completar um plano de marketing sobre os produtos (foco na compreensão escrita), preparar folheto (foco na produção escrita) com conhecimentos de aplicações informáticas. Ao apresentar o folheto ao grupo, o foco incide na produção oral. Porém, como o foco não foi na interação da apresentação do folheto, e sim na sua preparação, consideramos que as habilidades mais desenvolvidas nessa tarefa foram a de escrever e ler.

Figura 18 - Habilidades integradas na Unidade 3 - destaque para a de maior ou menor proporção

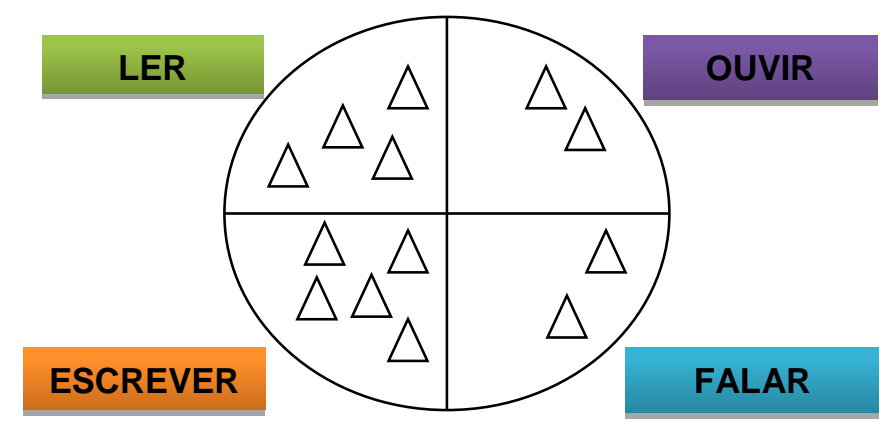

Para a unidade 4 (comunicação), foram definidos dois tópicos: Clientes e fornecedores; e Documentos, Logística e Transporte, tendo, como recortes comunicativos para LT, "Participar de uma conversação entre cliente e fornecedores (entre 2 ou mais pessoas) 
pessoalmente, por $e$-mail e por telefone parar tratar sobre solicitação de pedidos, lendo documentos, informando prazos e condições de transporte". Para alcançar esses objetivos, foram levantadas, incialmente, reflexões sobre "diferentes formas de comercialização e negociação e sobre como deve ser o perfil de um bom vendedor" atendendo à articulação do recorte para LT e ST, que é "Refletir sobre a relação interpessoal entre clientes e fornecedores: persuasão e bom atendimento", materializadas em sala de aula na seguinte TF:

Os alunos refletem sobre diferentes formas de comercialização e negociação e sobre como deve ser o perfil de um bom vendedor -> Cada grupo prepara cartões de visita $->$ Interage com fornecedores e expositores numa feira $->$ Anota informações sobre os produtos $->$ Confere os produtos que desejam solicitar -> Contata com fornecedores e expositores por e-mail-> Prepara os documentos necessários para esses trâmites $->\mathrm{O}$ fornecedor confirma dados de um pedido com o cliente por telefone e fala dos trâmites da entrega e transporte.

Para o cumprimento da TF, foram consideradas as seguintes ações:

Ação 1 - Compartilhar informações sobre diferenças culturais na hora de comercializar e negociar e expressar opinião sobre a postura de um vendedor/negociador (obrigação e necessidade).

Ação 2 e 3 - Preparar cartões de visita.

Ação 4 e 5 - Interagir com fornecedores e expositores numa feira pessoalmente.

Ação 5 e 6 - Contatar fornecedores e expositores por e-mail solicitando produtos pré selecionados no catálogo.

Ação 7 - Preparar documentos necessários para trâmites de solicitação de mercadorias,

Ação 8 - Confirmar dados de um pedido com o cliente por telefone, falando dos trâmites da entrega e transporte. 
Figura 19 - Habilidades integradas na Unidade 4 - destaque para a de maior ou menor proporção

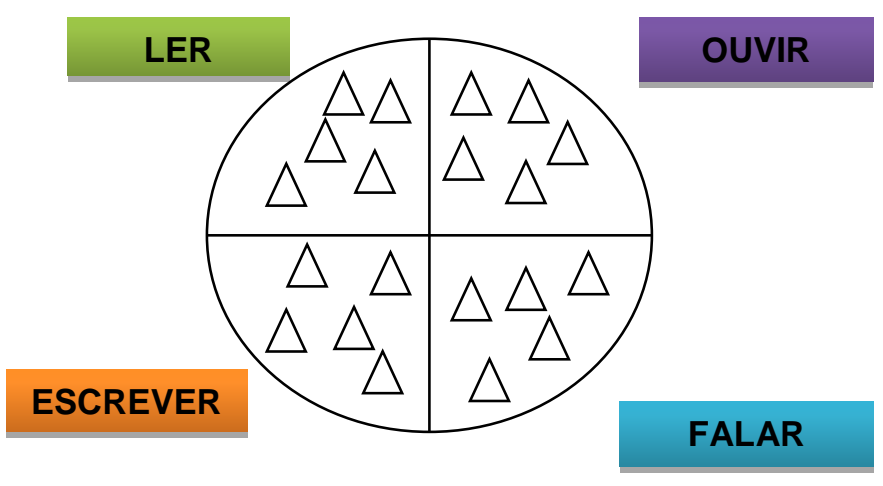

Retomando a nossa primeira pergunta de pesquisa: Como se configurou a construção de um planejamento CLIL por tarefas para o ELFE na educação profissional técnica de nível médio subsequente? Apresentamos de forma resumida na figura a seguir o fluxo utilizado para a organização das unidades temáticas anteriormente mencionadas.

Figura 20- Fluxo da construção do planejamento de curso de LE na EPT

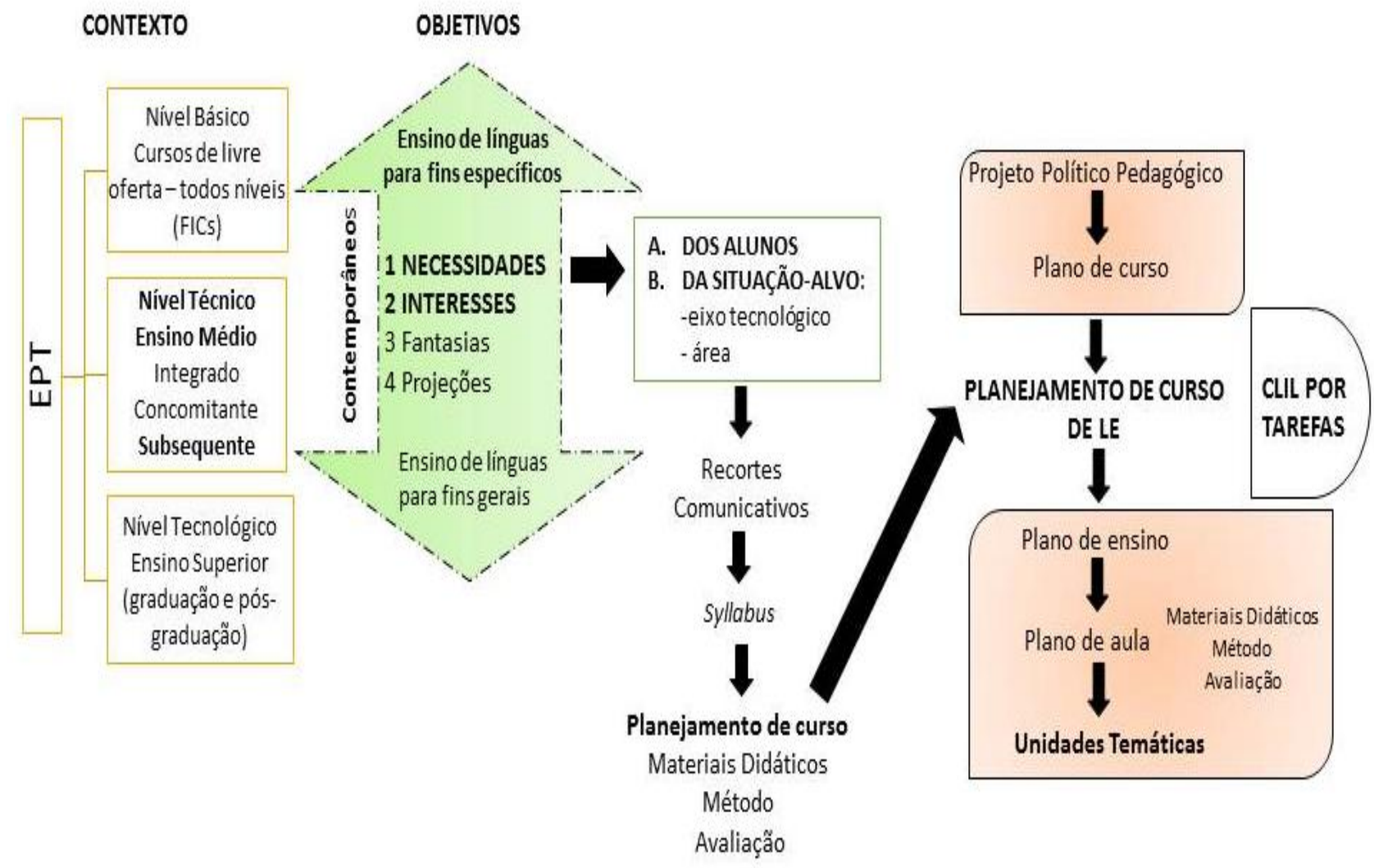

Fonte: Elaborado pela autora 
Para o ELFE buscamos nos apoiar em seu princípio fundamental: análise de objetivos, e ao considerarmos o nosso contexto de EPT, o levantamento de objetivos passou a preponderar, portanto, o atendimento às "demandas dos cidadãos, do mercado e da sociedade" (previsto na legislação vigente da EPT de nível técnico), numa relação direta com os objetivos (necessidades e interesses) dos alunos, da situação-alvo e da contemporaneidade, explicitados a seguir:

$\checkmark$ Objetivos dos alunos - demandas dos cidadãos;

$\checkmark$ Objetivos da situação-alvo: eixo tecnológico (Gestão e Negócios) e área específica (Logística) - demandas do mercado de trabalho;

$\checkmark$ Objetivos contemporâneos para a LE e conhecimentos gerais - demandas da sociedade.

E, a preponderar, também, outros objetivos da própria legislação da EPT, como por exemplo: flexibilidade, interdisciplinaridade e contextualização; relação entre trabalho, cultura, ciência e tecnologia; respeito aos valores estéticos, políticos e éticos, entre outros.

Foi, portanto, a partir do procedimento de análise de objetivos que levantamos os recortes comunicativos (ações integradas de uso social do cotidiano pessoal e profissional). Esses recortes nos proporcionaram dados para a delimitação do syllabus (conteúdo/temas e tarefas) do nosso planejamento de curso que teve como objetivo o desenvolvimento de competências para a formação cidadã e profissional na, para e pela Língua(gem).

A fim de obter os resultados esperados, optamos pela proposta de planejamento de curso de LE na EPT baseado no ensino e aprendizagem dual, simultâneo de conteúdos/temas e língua, na relação conteúdo/temas, comunicação/língua(gem), cognição/aprendizagem/, cultura e contexto/ ambiente, dimensões do CLIL ou os 4Cs (MARSH et al., 2001; DO COYLE, 2006) articulado ao trabalho, tecnologia, ciência e cultura (BRASIL, 2012; MOURA, 2008, 2010, 2012; FRIGOTTO, CIAVATTA e RAMOS, 2004, 2012) visando ao desenvolvimento de competências básicas e competências profissionais em atendimento às demandas dos cidadãos, do mercado e da sociedade. Da mesma forma, buscamos o desenvolvimento de uma CC, entendida também, nesse trabalho, como competência básica e profissional na contemporaneidade.

Nessa perspectiva, delineamos para o nosso planejamento CLIL por tarefas a relação entre Língua(gem)/Trabalho e Sociedade/Trabalho como possibilidade de contextualização social do aluno como aprendente de LE, e como sujeito, mobilizando suas potencialidades 
humanísticas e competências básicas (gerais) e profissionais (específicas) direcionando para um agir em contextos sociais, sob as perspectivas da ação comunicativa e estratégica/instrumental de Habermas (2012), de forma a ampliar o acesso a novos temas, à cultura, à ciência e a participação em práticas sociais por meio da tecnologia, conforme explicitamos na figura a seguir:

Quadro 19- Relação entre os princípios de ELFE, EPT e CLIL

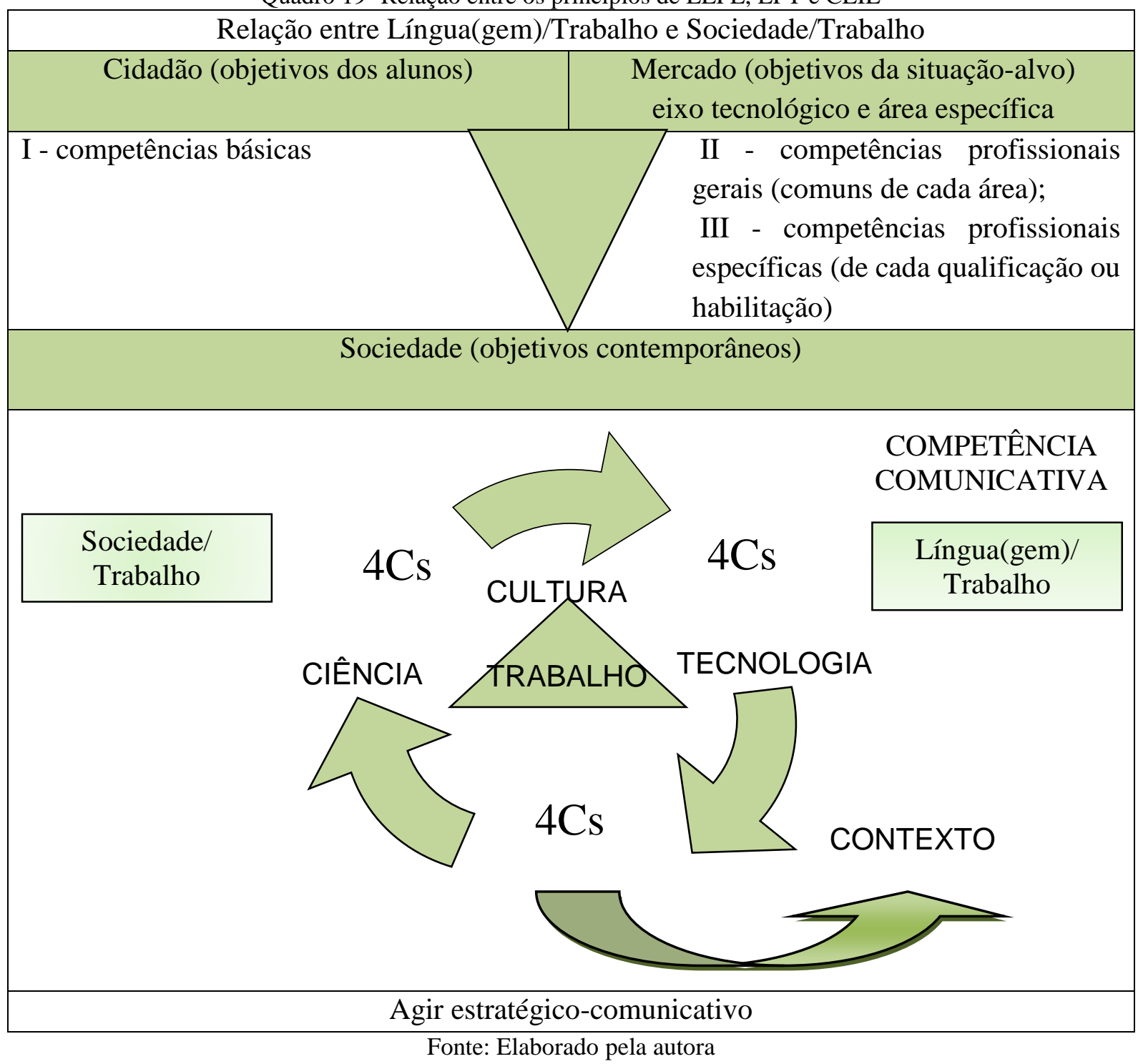

Entendemos que ao buscarmos por meio de temas, desenvolver nos alunos competências de uso na nova língua (competência comunicativa) que fossem capazes de posicioná-los socialmente como cidadãos e profissionais (formação integral), pressupomos a ausência de hierarquia entre os saberes. Sendo assim, tanto o desenvolvimento da CC pelo conteúdo/temas e quanto o desenvolvimento de conhecimentos, valores e atitudes na, para e 
pela língua(gem) com vistas a uma formação integral humana passam a ser igualmente avaliados.

Com base no exposto acima, cada unidade temática do planejamento proposto está pensada para iniciar-se com tarefas de "reflexão" sobre alguma temática do cotidiano e finalizar-se com a tarefas de "participação" A estrutura de cada unidade temática (apêndice I) seria, portanto, a seguinte:

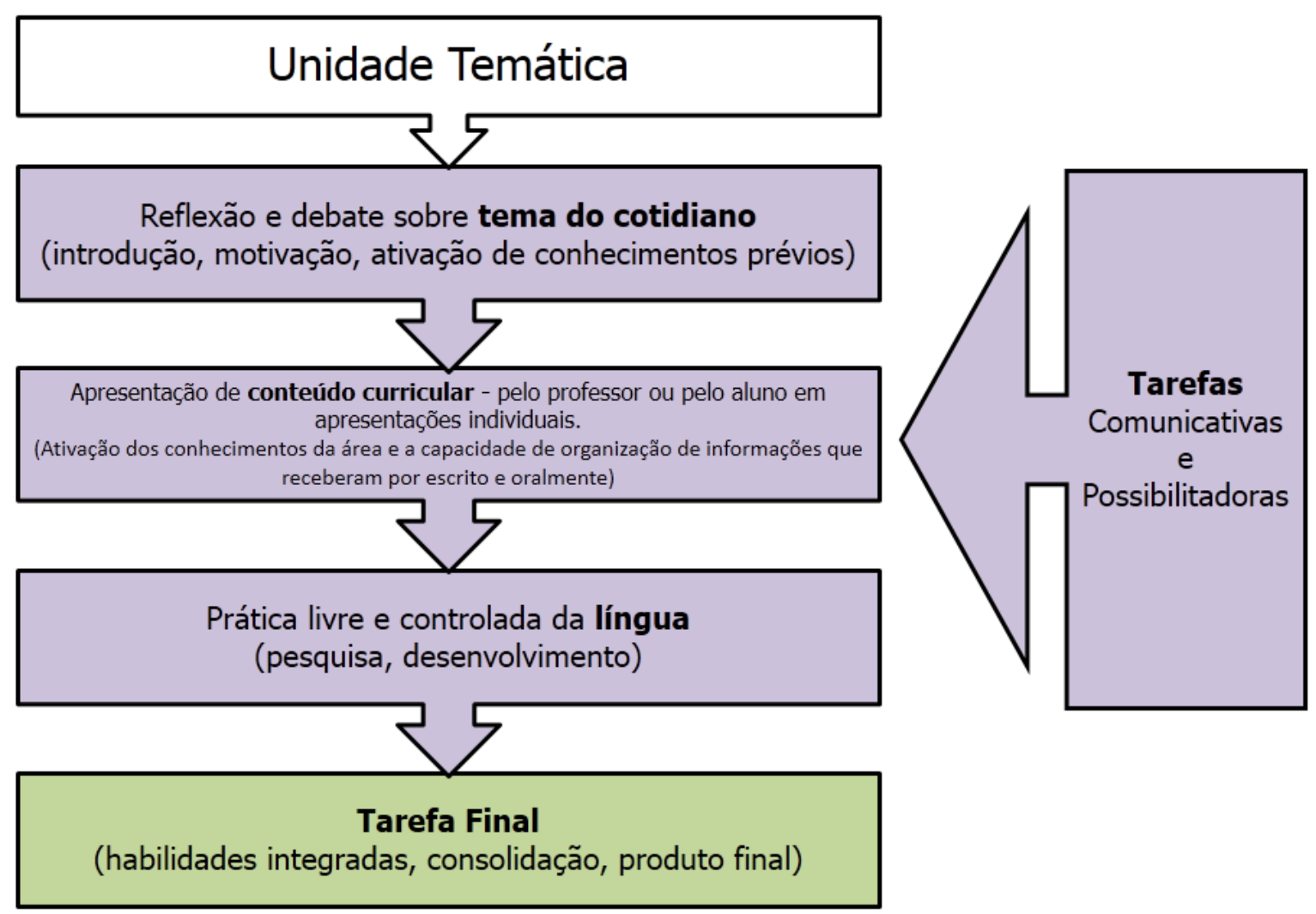

Assim, após discutirmos nessa parte I os procedimentos de elaboração de um planejamento CLIL por tarefas para o ELFE na EPT técnica de nível médio subsequente, passaremos à análise da implementação do planejamento proposto (parte II), a partir da percepção dos próprios alunos. 


\subsection{PARTE II - DA IMPLEMENTAÇÃO À AVALIAÇÃO DO PLANEJAMENTO DO CURSO}

Para respondermos à segunda pergunta de pesquisa - que implicações o planejamento proposto pode ter para o desenvolvimento da competência comunicativa (CC) na L-alvo e para a formação integral (FI) dos alunos a partir de suas próprias percepções? analisamos a visão do aluno sobre vários aspectos de sua aprendizagem, relatadas no questionário final, retomamos à literatura da área e aos instrumentos da Parte I (documentos, análise de objetivos, elaboração do planejamento), e traçamos uma relação com a visão do aluno relatada no diário dos alunos, conforme expressamos na ilustração a seguir.

Figura 22 - Triangulação dos instrumentos gerados na Parte I e Parte II

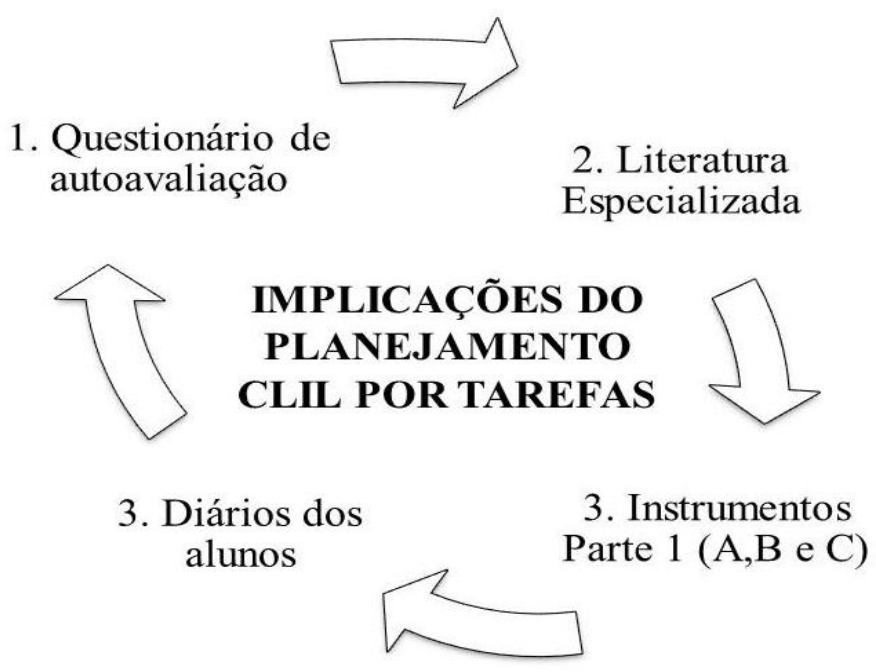

Assim sendo, essa análise explora a relação entre o modo como o planejamento foi organizado e os seus efeitos para o desenvolvimento de competências (CC e FI). Codificamos, primeiramente, a percepção geral do grupo sobre as competências desenvolvidas durante o curso, o que nos conduziu a algumas questões analíticas (subquestões): quais os fatores que contribuíram ou não para o desenvolvimento da CC e FI dos alunos? Quais os potenciais e as limitações do planejamento proposto?

Segundo Creswell (2010, p. 217), a análise e interpretação dos dados "trata-se de um processo permanente envolvendo reflexão contínua sobre os dados, formulando questões analíticas e escrevendo anotações durante todo o estudo". As questões analíticas surgiram, também, durante o processo de aplicação do planejamento e foram nos direcionando para a elaboração das perguntas do questionário final de autoavaliação. 
As percepções dos alunos (amostra de 21 alunos), no questionário final, sobre seu próprio desempenho, nos proporcionaram a aproximação de algumas características do planejamento CLIL por tarefas que foram categorizadas e relacionadas com as descritas pelos alunos em seus diários, durante a implementação do planejamento. O desempenho está embutido no conceito de Hymes, por meio da expressão "capacidade para usar". E, para que o aluno pudesse avaliar essa capacidade, utilizamos o procedimento de "análise de desempenho", que é uma descrição do processo (de aprender) e explicitação analítica da qualidade da atuação acadêmica do aprendiz de línguas (GLOSSA-LA). Sendo assim, para a descrição do processo de aprender, foram definidos critérios subjetivos de uma autoavaliação. Para os diários, foram solicitadas reflexões em cada encontro sobre como e quais atividades possibilitaram o desenvolvimento dos alunos e foi solicitado, ainda, que os alunos avaliassem o seu desempenho: muito bom, bom, aceitável, ruim, muito ruim. Esses critérios também foram utilizados no questionário final de autoavaliação do grupo.

Concordamos com Miccolli (op. cit.), quando esta afirma que, apesar de o aluno ser responsável pelo seu desempenho, a prática pedagógica deve ser vista como um importante fator de influência no bom ou mau desempenho dos alunos. Foi em vista disso que buscamos identificar dados que pudessem sinalizar os fatores, elementos, características do planejamento proposto que contribuíram para o desempenho satisfatório ou não. Para a autora (op. cit. p. 162), “o desempenho do aluno é uma questão complexa, porque o professor não pode se eximir de sua corresponsabilidade pelo desempenho dele", ao mesmo tempo, se o aluno também não se responsabiliza pela sua própria aprendizagem, se torna passivo em sala de aula, e o seu desempenho "seria apenas reflexo das ações do professor".

Ao ser solicitado aos alunos, no questionário final de autoavaliação que atribuíssem uma classificação para o seu desempenho geral em LE, no final do curso, e justificando sua escolha (fatores que contribuíram para isso), 52,3\% dos alunos responderam que tiveram bom desempenho em LE; 23,8\% muito bom; e 23,8\% aceitável, em decorrência de fatores individuais do próprio aluno e/ou em decorrência das escolhas da prática docente (dinâmica das aulas). O que nos motivou a separar, assim, a primeira categoria de análise entre duas perspectivas:

\footnotetext{
$\checkmark$ Responsabilidade do aluno

$\checkmark$ Prática pedagógica
} 
Interpretamos que a aprendizagem dos alunos depende, principalmente, dessas duas perspectivas, além de fatores a eles adversos que permeiam todo o processo (estrutura da instituição, conhecimento prévio do aluno, etc.).

Os dados resultantes desses dois pontos passam a ser codificados e categorizados a seguir, e o seu resultado triangulado com as caraterísticas de um planejamento CLIL por tarefas, apresentadas na literatura e, também, com os excertos dos alunos, objetivando responder a nossa pergunta de pesquisa quanto às implicações (positivas ou não, favoráveis ou não) do planejamento proposto para o desenvolvimento das competências estabelecidas como metas.

Quanto aos fatores de sua própria responsabilidade, é possível perceber que o desempenho (muito bom/bom) foi gerado pelo esforço, motivação e grande interesse/vontade de aprender, participação nas aulas e dedicação; e, para o desempenho aceitável, dificuldade de aprender, falta de dedicação apresentados nos excertos do quadro a seguir:

Quadro 20 - Autoavaliação dos fatores individuais que contribuíram para a aprendizagem dos alunos

\begin{tabular}{|c|c|}
\hline \multicolumn{2}{|r|}{ Responsabilidade dos alunos } \\
\hline Muito Bom & $\begin{array}{l}\text { - Porque me esforcei ao máximo para aprender o espanhol. } \\
\text { - Motivação e grande interesse de aprender a matéria. }\end{array}$ \\
\hline Bom & $\begin{array}{l}\text {-Pela minha força de vontade, participação, de querer assistir as aulas e me } \\
\text { esforçar, dentro de sala de aula, sem que atrapalhasse meus colegas e } \\
\text { também professor. } \\
\text { - Participei das aulas, fiz os trabalhos e as atividades, porém poderia ter } \\
\text { participado mais e me esforçado mais. } \\
\text { - Me esforcei ao máximo, me dediquei na matéria } \\
\text { - Consegui me soltar mais. } \\
\text { - No começo do curso confesso que me assustei pensando que não ia dar conta, } \\
\text { mais com o passar do tempo vi que não era tão difícil assim só precisava de } \\
\text { um pouco de esforço da minha parte e no final deu tudo certo. } \\
\text { - Bom pelo meu desempenho esforço de fazer os trabalhos. } \\
\text { - Procurei me informar sobre as atividades, trabalhos e conteúdos e não } \\
\text { deixei de entregar e nem apresentar nenhum deles. }\end{array}$ \\
\hline Aceitável & $\begin{array}{l}\text { - Devido à dificuldade de aprender e falta de dedicação em alguns momentos } \\
\text { - Às vezes, quando não sabia os significados das palavras. Poderia ter me } \\
\text { dedicado mais as aulas de espanhol, mas por vários motivos não o fiz. }\end{array}$ \\
\hline
\end{tabular}

Fatores Adversos (greve de ônibus, trabalho, dificuldade de conciliar dois cursos, cansaço, falta de tempo, correria do dia a dia) e problemas pessoais geraram um desempenho muito bom ou aceitável para alguns alunos. 
$\checkmark \quad$ Devido a meu trabalho onde o horário e os dias ficam oscilando.

$\checkmark \quad$ Um pouco de dificuldade de conciliar dois cursos.

$\checkmark \quad$ Não só por causa da correria do dia a dia, de associar trabalho e estudo.

$\checkmark \quad$ Não foi fácil, muito corrido, mas enfim consegui.

$\checkmark \quad$ Aprendi muito esse semestre mesmo a matéria sendo corrida.

$\checkmark \quad$ Por conta de reuniões no trabalho e até mesmo greve dos ônibus não consegui ser $100 \%$ assídua nas aulas.

$\checkmark \quad$ No início foi mais complicado devido fazer muito tempo que não tinha contato com o idioma e o pouco conhecimento sobre o idioma.

$\checkmark \quad$ No início foi muito complicado, pois não tinha conhecimento da matéria.

$\checkmark \quad$ Devido ao cansaço e falta de tempo. Tive muita dificuldade em acompanhar o curso e um dos fatores foi nunca ter estudado ou falado alguma palavra em espanhol.

Para Xavier (1999), é necessário que o aluno estabeleça o grau de comprometimento com a sua aprendizagem, querer, ter vontade, metas e intenção de aprender, avançar. É nesse sentido que a aprendizagem, para a autora, não é apenas um processo cognitivo, autorregulador e social, mas também motivacional. Buscamos desenvolver a consciência da importância de sua participação e de sua responsabilidade no processo de aprendizagem, bem como a consciência do processo ("o que vamos fazer neste curso e como?"), de forma que pudessem estabelecer suas próprias metas, provocando-os, ainda, para que avaliassem o progresso e o grau de alcance dos resultados de aprendizagem (MEHISTO, MARSH e FRIGOLS, 2008).

Para isso, partimos do pressuposto que a consciência do aluno sobre o processo e que atender as suas necessidades e seus interesses poderia conferir um grau de comprometimento, responsabilidade e autonomia capaz de levá-los a desenvolver-se eficazmente em uma LE.

No entanto, os excertos a seguir evidenciam que os alunos percebem que houve, no planejamento, um direcionamento para os seus objetivos, demonstraram certo entusiasmo "parece que vai ser divertido", "se for vai ser bom”, "importante saber disso", mas não demonstraram inicialmente grau de comprometimento, e sim impressões quanto ao tipo de planejamento "grande volume de questões para ser resolvidas", "muito material”, "matéria corrida”. 


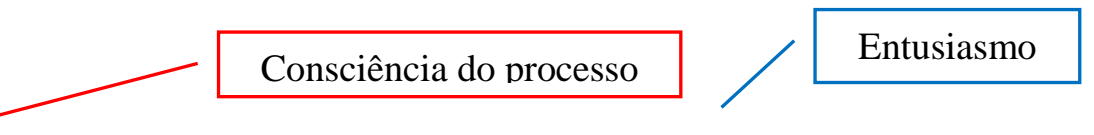

$\checkmark \quad$ Fiquei pensando se será somente conversação. Se for vai ser bom, porque foi o que o grupo pediu, para direcionar as aulas para o que vamos precisar (A2, Aa 1).

Direcionado

$\checkmark \quad$ Gostei de ver que íamos falar de assuntos interessantes para a nossa vida e para a nossa profissão e não ficar vendo gramática, decorando frases, essas coisas. ser divertido $(A 4, A a 2)$.

$\checkmark \quad$ A professora nos deixou à vontade para escolher como gostaríamos que fossem aplicadas as aulas (A5, Aa 2).

$\checkmark \quad$ Foi importante saber como tudo vai ser e que muitas foram de nossa escolha $(A 3, A a)$.

Algumas impressões sobre o planejamento e o fato de não ter conhecimento prévio na língua, "nunca ter estudado", "nunca ter tido contato”, "pouco conhecimento", para acompanhar as aulas de CLIL, que, segundo os alunos tinham muito conteúdo e muita informação, levou grande parte do grupo a uma preocupação inicial.

Preocupação inicial

Grande volume de questões informações

$\checkmark \quad$ Confesso que fiquei assustada, for que pensei comigo mesmo, se no primeiro dia de aula a professora chega com uma lista enorme de questões pra gente resolver, imagina nas aulas que tem pra frente (A3, Aa 1)

Dificuldades: contato prévio com a L-alvo

Logo que começou a aula fiquei muito nervosa pois nunca tive contato com espanhol. A professora já chegou falando tudo em espanhol nossa que “desespero”. (A1, Aa 1)

Achei muita informação, muito material. Nunca estudei espanhol e a professora só falava em espanhol, não consegui entender muito. Fiquei apavorado. (A5, Aa 1)

Carga horária reduzida

$\checkmark \quad$ No começo das aulas de espanhol achei a matéria muito corrida. muitas apostilas como eu nãa conseguia entender o que a professora falava me assustei com a matéria (A4, Aa10)

Dificuldades: entendimento 
$\checkmark \quad$ Em meu primeiro contato fiquei surpreso, interessado em aprender, achei um pouco difícil de entender algumas palavras achei meio enrolado algumas palavras (A2, Aa 1)

Entretanto, observamos que esses fatores foram amenizados pela vontade de aprender e pela afinidade que começaram a ter pelo componente curricular, conforme se percebe nas transcrições a seguir:

$\checkmark \quad$ Senti dificuldades devido ter muito tempo que não via nada referente ao assunto, mas tive muita vontade de aprender (A1, Aa 1)

Vontade de aprender e afinidade pelo componente

$\checkmark \quad$ Pensei que ia me dar mal, mas logo no início já comecei a gostar. $(A 4$, Aa 1)

$\checkmark \quad$ Podemos perceber que, à medida que os alunos começam a se envolver com os temas e com as tarefas, passam a se esforçar mais e a se arriscar, apesar das dificuldades quanto aos fatores adversos: pouco conhecimento de LE, carga horária reduzida.

Interpretamos que a motivação intrínseca, a vontade de aprender e a extrínseca afinidade pelo componente pelo componente geraram um esforço, dedicação, participação, "correr risco" e tranquilidade evidenciados nas transcrições a seguir:

Esforço, "correr risco", dedicação, participação

$\checkmark \quad$ (...) tive dificuldade em entender a pronuncia e a escrita, me arrisquei em falar algumas palavras e escrever algo em espanhol. (A1, Aa 1)

$\checkmark \quad$ Me arrisquei em tentar fazer as atividades na sala, mas tive muitas dúvidas, ás vezes não conseguia fazer, se tivéssemos mais tempo gostaria que fosse mais devagar (A5, Aa 6).

$\checkmark \quad$ No segundo dia de aula eu fiquei um pouco assustada também, por que a professora entrou na sala de aula falando tudo em espanhol, então tinha coisas que eu não conseguia acompanhar, mas logo em seguida fui me acostumando com o jeito dela falar mesmo sem entender algumas coisas e passei a tentar participar das atividades. (A3, Aa 2)

$\checkmark \quad$ Apesar das dificuldades ${ }_{2}$ estou desenvolvendo muito e estou gostando muito das aulas (A1, Aa 7).

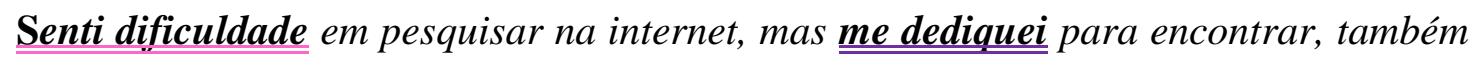
não mudaria nada. (A1, Aa 2) 
$\checkmark \quad$ Bom fiquei um pouco meio sem ideia como falar, apresentação em grupo sobre a empresa e organograma, mas me esforcei tentei falar. (A2, Aa 3)

$\checkmark$ Notei que não era tão difícil quanto eu pensei ai logo fui ficando mais calma. (A4, Aa 1)

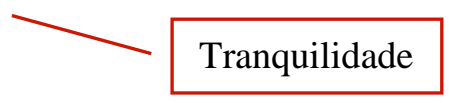

Nessa perspectiva, podemos inferir que a motivação em sala de aula pode ser medida em nível de participação dos alunos (ação) ou a participação está associada ao fator de personalidade? Timidez, inibição, extroversão, autoestima, etc.? Ou ambos?

Brown (2007) destaca que os fatores de personalidade contribuem para o sucesso da aprendizagem de línguas. Para o autor, não há dúvida sobre a importância de analisar esses fatores, porém ele ressalta que o domínio afetivo é difícil de descrever cientificamente ${ }^{51}$, já que grandes números de variáveis estão implícitos ao considerar o lado emocional do comportamento humano nesse processo. $\mathrm{O}$ autor afirma que cada aprendiz tem uma personalidade a qual condiz com suas atitudes em sala de aula, ou seja, suas características comportamentais; e argumenta que não se pode definir que a aprendizagem acontece pelo lado afetivo ou cognitivo, mas que ambos são indissociáveis para uma aprendizagem satisfatória (Conf. VYGOTSKY).

Ao ser perguntado aos alunos "como foi sua participação durante as aulas?", interpretamos que a participação (ou não) se deu em decorrência do próprio tipo de personalidade (inibição) ou do formato do tipo de planejamento CLIL por tarefas, que estabelece (participação ativa dos alunos), e não necessariamente quando se sentem motivados, conforme explicitado nos excertos dos alunos no questionário de autoavaliação:

$\checkmark \quad$ Boa. Sou mais calada, porém presto bastante atenção e participo sempre que necessário.

$\checkmark \quad$ Sempre tento participar, pois com isso consigo me desinibir, pois sou tímido, e sei que participando estou me ajudando e também tiro minhas dúvidas.

$\checkmark \quad$ Razoável. Como em todas as aulas sempre tínhamos que participar acredito que participei de todas. Mas nunca sabíamos quando seria solicitada nossa participação, ficava atento.

\footnotetext{
${ }^{51}$ Rubem Alves (2002, p 97) ao refletir sobre o que (não) pode ser explicado cientificamente, traz as palavras de Manoel de Barros "A ciência pode classificar e nomear os órgãos de um sabiá, mas não pode medir seus encantos."
} 
Não podemos afirmar que alunos menos desinibidos e que participam mais têm um desempenho melhor, porém podemos inferir, a partir das respostas dos alunos, que participar nas aulas é uma forma de se ajudar e também de tirar suas próprias dúvidas. Sendo assim, a participação do aluno é atributo relacionado a sua personalidade ou a configuração do próprio tipo de planejamento. É importante reconhecermos diferenças individuais entre os alunos ao avaliá-los a fim de evitar que seja feita em termos de grau de maior ou menor participação. Em um planejamento CLIL, espera-se que a participação do aluno seja mais ativa, que por vezes não é atingida em sua plenitude pelo fator "timidez", dessa forma, respeitar a individualidade do aluno é um atributo importante para o professor.

Buscar a participação dos alunos pela via da motivação é o que se espera do professor de CLIL. Para tanto, buscamos verificar a relação direta entre as interações na sala de aula e o desempenho dos alunos, analisando as práticas que foram favoráveis para a mobilização (motivação) dos alunos no processo de aprendizagem. Quanto ao seu desempenho em LE, obtivemos os seguintes resultados.

Quadro 21 - Autoavaliação das interações nas aulas

\section{Interações nas aulas}

\begin{tabular}{|c|c|}
\hline $\begin{array}{l}\text { Muito } \\
\text { Bom }\end{array}$ & $\begin{array}{l}\text { - O conteúdo foi disseminado de forma bastante diversificada facilitando a } \\
\text { introdução da nova língua. } \\
\text { - Gostei de entender o que a professora falava e também os vídeos. Isso é } \\
\text { importante, porque se fica só mandando repetir frases não sei se consigo } \\
\text { entender um vídeo, uma palestras, algo que falem mais e mais tempo em } \\
\text { espanhol. } \\
\text { - Aforma de apresentação das aulas, os trabalhos orais, as pesquisas sobre os } \\
\text { temas. } \\
\text { - Apresentação de músicas, filmes, vídeos. } \\
\text { - Aulas dinâmicas, em círculo, em grupo. }\end{array}$ \\
\hline Bom & $\begin{array}{l}\text { - Gostei muita das aulas. Tinha momentos de descontração e conversa com } \\
\text { colegas. } \\
\text { - Me senti mais endereçado em outras línguas pela maneira inovadora de se } \\
\text { apreender. A dinâmica, mas o principal a pesquisa em grupo. } \\
\text { - as dinâmicas nas aulas, os diálogos, o autoconhecimento da professora. } \\
\text { - A dedicação e o bom método utilizado pela professora aulas dinâmicas e } \\
\text { interativas. As brincadeiras e a forma que a professora conduzia a aula. } \\
\text { - Um dos fatores que contribuíram foi a ótima preparação da professora. Suas } \\
\text { aulas eram sempre dinâmicas e de muita descontração que facilitou muito no } \\
\text { meu desenvolvimento. } \\
\text { - Trabalhos, slides, vídeos, comunicações dentro da sala de aula. }\end{array}$ \\
\hline
\end{tabular}




\begin{tabular}{|c|c|}
\hline & $\begin{array}{l}\text { - A diversidade nas atividades em sala, como músicas, leitura, lidar com dados } \\
\text { das empresas. } \\
\text { - Por a aula ser dinâmica, onde foi puxado dos alunos os seu desempenho } \\
\text { individual e pelos trabalhos em equipe. A professora fez com que ninguém } \\
\text { ficasse com vergonha ou medo de falar e apresentar os trabalhos em espanhol. }\end{array}$ \\
\hline Aceitável & $\begin{array}{l}\text { - Algumas palavras ficaram meio que emboladas, ai já na percepção fui me } \\
\text { encontrando tanto na escrita e oral. } \\
\text { - Quando nos era passado filme, vídeos, não me concentrava muito. O som era } \\
\text { ruim e me dispersava, fazia outras coisas enquanto isso. }\end{array}$ \\
\hline
\end{tabular}

Quanto às interações, a forma diversificada das atividades, dos trabalhos, a forma de apresentação e condução das aulas (dinâmicas, interativas), momentos de descontração, conversa com os colegas, pesquisa em grupo, o bom método, favoreceram o bom/muito bom desempenho. Os alunos atribuem, ainda, o desempenho muito bom/bom ao clima amistoso que foi criado pelo grupo:

$\checkmark \quad$ Na minha opinião, o respeito, a amizade e o entrosamento da turma, contribui muito para o meu desempenho nas aulas de espanhol e também em todas as outras.

$\checkmark$ A atmosfera respeitosa e envolvente.

$\checkmark$ A forma de ensino, a ajuda dos colegas e o clima que tivemos em sala todos muito amigos e unidos.

$\checkmark$ Aprendendo um com outro.

$\checkmark$ O bom relacionamento entre turma e professor.

Para o desempenho aceitável, os alunos esclarecem o fato da matéria "ser corrida", "muita" e o curso ser condensado em apenas um dia na semana.

$\checkmark$ Achei duas matérias um pouco corridas: Contabilidade: mas já tinha boa noção Espanhol: achei muita matéria no início, mas consegui me virar.

$\checkmark$ As aulas poderiam ter sido mais dividas na semana, para ter mais flexibilidade nas aulas e nos horários, e não serem só em um dia na semana.

$\checkmark$ Muita informação, mas vi depois que isso motivou a gente, os assuntos eram interessantes.

$\checkmark$ No começo achei difícil. Ter que escutar falar muita coisa em espanhol. Não achei que fosse ser assim. 
É importante considerar a relação tempo e o alcance dos objetivos em um planejamento de curso. Para a pesquisa, foi realizado um planejamento levando em consideração 40h/a, em 10 encontros de 4h/a. A expectativa de desenvolver os conteúdos/ temas e tarefas propostas no tempo estimado resultaram em aulas corridas, e tempo insuficiente na percepção dos alunos para a aprendizagem.

Os alunos avaliaram ainda quais procedimentos, técnicas e recursos foram mais significativos para a sua aprendizagem e citam, por exemplo, o trabalho em grupo com manipulação das informações, criação de um produto, apresentação dos resultados das atividades, apresentação de temas e teatro, atividades escritas e uso de recursos como música e vídeos.

\section{$\checkmark \quad$ Os trabalhos em grupo.}

$\checkmark \quad$ A atividade que preparamos em grupo para falar de um produto.

$\checkmark \quad$ Músicas, filmes, atividades em grupo, dinâmicas.

$\checkmark \quad$ As leituras e debates sobre temas diversos.

$\checkmark \quad$ Parte da música e o modo da professora falar.

$\checkmark \quad$ Gostei muito da apresentação dos temas logísticos, achei bem proveitoso. O trabalho e a apresentação da feira dos produtos foi bem legal e bastante interessante.

$\checkmark \quad$ As em grupo de apresentar um assunto na frente pesquisar e apresentar os teatros, as músicas.

Atividades escritas, porque nos proporciona ver como se escreve, pronuncia e fica mais esclarecedor.

As atividades relacionadas com a criação e estudo da empresa. Pois são abordados diversos fatores necessários para comunicação.

Levando em consideração que o desempenho do aluno depende de seu esforço, e comprometimento e das escolhas pedagógicas, encontramos, nas falas dos alunos, pontos convergentes com nossas escolhas, a partir da literatura sobre o planejamento CLIL por tarefas, entre eles:

1. Ambiente Cooperativo

2. Temas relevantes

3. Tarefas da vida real 
Cada elemento que possa ter tido efeito positivo na aprendizagem dos alunos, em termos de CC e FI, passa a ser detalhado, na intenção de traçar uma relação com a percepção dos alunos durante o processo, relatada nos diários.

\section{Ambiente cooperativo}

O planejamento CLIL por tarefas ressalta a importância de nos apoiarmos em ambiente cooperativo para a realização das tarefas e interações em sala de aula. Um ambiente cooperativo está intimidante relacionando com a interação entre os alunos e a negociação de significados. Para Xavier (1999), a negociação por meio da interação leva os alunos, em uma tarefa, a chegar a um produto final. Para Mehisto, Marsh e Frigols (2008) o professor, ao atuar como facilitador, negocia o significado da língua(gem) e o conteúdo com o aluno.

Buscamos promover o processo em um ambiente colaborativo, com interação em pares, pequenos grupos e coletiva. Delimitamos, no primeiro dia de aula, a separação dos grupos, as tarefas e os objetivos que deveriam alcançar. O entusiasmo que passaram a ter pela língua foi ocasionado, também, pelo ambiente colaborativo que permitiu que a participação fosse motivada pelos demais colegas. Trazemos algumas evidências.

$\checkmark \quad$ Me senti motivado na hora de trabalhar em grupo e explorar uma atividade diferente. (A1, Aa3)

$\checkmark \quad$ Me senti a vontade trabalhando em grupo e motivado com o assunto (A1, Aa6)

$\checkmark \quad$ (...) formamos grupos e começamos a fazer o trabalho em equipe, um ajudando o outro (A3, Aa 2)

Negociação do significado: Trabalhos produtivos

(...)o trabalho em grupo junta as ideias e sai muita coisa produtiva, me arrisquei dando opiniões e compartilhando ideias. (A1, Aa 3)

Grau de envolvimento gerada pela interdependência para o alcance de objetivos de todo o grupo

(...)ficou um pouco enrolado mais me esforcei colocar os preços também junto como os meus colegas. (A2, Aa 6$)$ 
Trabalhar em grupo e envolvê-los em tarefas maiores permitiu aos alunos conhecer a opinião dos demais membros do grupo e sentir-se à vontade também para opinar, conforme menciona o A1 em seu diário. Muitos alunos consideraram o trabalho em grupo, a atividade diferente (o uso da internet) como pontos relevantes para seu engajamento e sua participação durante as tarefas desempenhadas em sala.

Para Estaire (1999, p. 1-2), algumas tarefas têm como o foco o desenvolvimento de uma aprendizagem mais consciente, responsável e autônoma. E uma forma de buscar a autonomia dos alunos é envolvê-los em trabalhos cooperativos, uma vez que nesses tipos de atividades os alunos desenvolvem gradualmente sentido de responsabilidade, pois precisam escolher entre diferentes opções, fazer sugestões, tomar decisões, chegar a acordos, cooperar eficazmente com os companheiros, planejar seu trabalho e avaliar seu próprio trabalho e dos outros.

O ambiente cooperativo fomenta o trabalho coletivo, a participação e o reconhecimento do aluno sobre as suas próprias competências para trabalhar em equipe. Ressaltam, por exemplo, que o grau de compromisso com as tarefas se tornam maiores, por existirem interdependências para o alcance dos objetivos de todo o grupo, o que fomenta uma preocupação com o grau de responsabilidade de forma a não prejudicar o grupo.

\section{Temas relevantes}

O planejamento CLIL maximiza a inclusão dos interesses dos alunos (MEHISTO, MARSH e FRIGOLS, 2008). Trabalhar temas relevantes e significativos para o seu universo, seja de conteúdo do próprio currículo e/ou temas do cotidiano, tem sido apontado pelos alunos como "interessante", conforme explicitado nos excertos a seguir:

Assunto de interesse: engajamento

$\checkmark \quad O$ assunto do trabalho foi muito interessante (...)gostei do assunto, cada grupo pesquisou sobre empresa diferente isso me ajudou bastante. (A3, Aa 2).

$\checkmark \quad$ Achei legal que falamos de coisas, envolveu a turma em conversa, achei que ia ser só conteúdo mesmo da língua. ( $A 4$, Aa 2)

Os temas, além de envolverem os alunos e promoverem o seu engajamento no processo, tiveram como objetivo fomentar reflexões em sala de aula. Além das reflexões no início de cada unidade, foi solicitado aos grupos que trouxessem para cada encontro notícias (atualidades), ocorridas no decorrer daquela semana, sobre a temática trabalhada, e outras que pudessem, 
também, interessar ao grupo. O grupo poderia escolher um porta-voz que leria a notícia. Nessa atividade, os alunos demonstraram ter tido dificuldade atribuída à correria do próprio dia a dia, impedindo-os de buscar e selecionar notícias para trazer para a sala. Perguntamo-nos se a forma como a atividade foi direcionada poderia ter sido diferente, pois observamos que, de fato, não houve engajamento dos alunos para essa tarefa.

\section{$\checkmark \quad$ Bem fiquei um pouco perdido na parte de apresentar notícias relacionadas ao mundo} (A2, Aa 2).

\section{$\checkmark \quad$ Não consegui trazer a notícias para a aula. Dia corrido (A1, A3). \\ $\checkmark \quad$ Não pesquisei as notícias que a professora pediu (A4, Aa 2).}

Além do painel de notícia, para cada aluno, foi definido um tema de conteúdo a ser apresentado brevemente para o grupo; os demais tomariam notas e tirariam dúvidas. Foram, no total, 25 apresentações individuais, com média de 5 minutos, divididas em diferentes aulas, segundo o conteúdo/tema de cada unidade. Com essa atividade, foi possível mobilizar os conhecimentos da área e a capacidade de organização de informações que receberam por escrito e oralmente. Para isso, foi entregue uma folha, em que deveriam apontar palavras-chave, ideias principais das apresentações dos colegas e entregar em forma de relatório no final do curso.

Considerar atividades e temas do cotidiano contribui para a reflexão dos alunos sobre temáticas até então não pensadas. O uso da língua para essas questões nos permitiu também oferecer oportunidade de comunicação real, uma vez que saber informações do cotidiano, discutir temas atuais na LE é, também, o que esperamos aprender na contemporaneidade. Em um curso de 40h/a, esse processo que deve ser iniciado no sentido de incentivar, motivar e apresentar formas do aluno obter isso de modo autônomo.

Além da ampliação de conhecimentos, o trabalho com temas permitiu a ampliação de valores humanos. Ao serem questionados sobre seus maiores "ganhos" em termos de formação cidadã e o que consideravam que haviam aprendido ou adquirido durante os nossos encontros e atividades, as respostas codificadas e categorizadas a seguir demostram que os alunos percebem mudanças em termos de valores e atitudes.

Quadro 22 - Maiores ganhos dos alunos em termos de formação cidadã mencionados na autoavaliação

\begin{tabular}{|l|l|}
\hline Reflexão & - Conhecer a opinião dos colegas me permitiu repensar algumas coisas \\
& que pensava antes \\
& - Novos olhares para a nossa situação pessoal \\
\hline
\end{tabular}




\begin{tabular}{|c|c|}
\hline & $\begin{array}{l}\text { - Foi importante conhecer a realidade de cada um (...) somos todos } \\
\text { diferentes, mas temos os mesmos objetivos crescer, avançar, mudar } \\
\text { sempre, ser melhores }\end{array}$ \\
\hline Confiança & $\begin{array}{l}\text { - Tentava sempre me colocar, ser quem eu era } \\
\text { - Ganhei confiança para apresentar na frente }\end{array}$ \\
\hline Respeito & $\begin{array}{l}\text { - O respeito e o incentivo para crescermos com profissionais e pessoas } \\
\text { foram bastante acentuados }\end{array}$ \\
\hline Cautela & - Pensar antes de falar várias coisas \\
\hline Otimismo & - Otimismo em algumas questões do dia a dia. \\
\hline $\begin{array}{l}\text { Consciência do } \\
\text { papel na } \\
\text { sociedade }\end{array}$ & $\begin{array}{l}\text { - (...) podemos participar com nosso ponto de vista; } \\
\text { - O nosso papel (...) para situações que tragam paz a todos; } \\
\text { - (...) contribuir para transformações da nossa sociedade. }\end{array}$ \\
\hline Novos laços & $\begin{array}{l}\text { - Poder conhecer as experiências dos colegas, conhecê-los um pouco } \\
\text { mais; } \\
\text { - Estreitou amizades (...) não julgar as pessoas. } \\
\text { - Ouvimos história de superação, incentivos e palavras confortantes } \\
\text { - Socialização entre todos. }\end{array}$ \\
\hline
\end{tabular}

O planejamento permitiu chamar atenção para a necessidade de uma compreensão intercultural ao introduzir contextos culturais maiores e a realidade dos próprios alunos. Nesse sentido, a exposição dos alunos a diferentes perspectivas, o compartilhamento de diferentes interpretações e o contato com outras realidades permitiram uma comparação com a própria realidade em que vivem, aumentando a consciência sobre si mesmo.

\footnotetext{
$\checkmark \quad$ (...) tive a oportunidade de conhecer o lado profissional de cada colega (A3, Aa 4)

$\checkmark \quad$ Vimos um vídeo para sabermos como nos apresentar, como nós comportamos na hora da entrevista, pois um processo de seleção não é fácil. (A4, Aa 4)
}

Quanto às formas de insumo para desencadear a discussão sobre um tema, o uso de filmes e músicas foi discutido pelos alunos em nível de interesse e motivação.

$\checkmark \quad$ A exibição do filme foi um aditivo que deixou não só a mim, mas a todos empolgados e interessados no desfecho da história apesar de não ter compreendido muito do filme (A1, Aa4).

\footnotetext{
$\checkmark \quad$ Com relação ao filme tive dificuldades no entendimento, mas a música deu uma levantada no astral motivando a todos e proporcionou uma diversão, arrisquei a cantar junto com todos (A2, Aa4).
} 
$\checkmark \quad$ Em relação ao filme não vou falar muito porque não consegui entender nada quase nada, ou seja, não gostei do filme, mas depois do filme veio a animação, que é me definir como personagem e cantamos uma música (...) tive a oportunidade de conhecer o lado profissional de cada colega (A3, Aa 4).

$\checkmark \quad$ Vimos um vídeo para sabermos como nos apresentar, como nós comportamos na hora da entrevista, pois um processo de seleção não é fácil (A4, Aa 4).

Não consegui descrever os personagens como tarefa de sala. Penso que se o filme fosse conhecido da maioria o rendimento seria melhor. Achei muito interessante a técnica do espelho. Adorei a música, muito animada (A5, Aa 4).

O planejamento CLIL mobilizou conhecimentos adquiridos em outras disciplinas e o acesso do aluno a diferentes formas de comunicação. O conhecimento prévio do conteúdo do curso foi apresentado como fator favorável para alcançar o objetivo da tarefa.

\footnotetext{
$\checkmark \quad$ A aula foi de analise Swot, por já ter visto esse conteúdo anteriormente consegui fazer as atividades (A4, Aa 2).
}

Quanto ao acesso dos alunos a outras formas de comunicação, verificamos que o planejamento CLIL guia o acesso a ambientes e a materiais autênticos e estabelece relações com outros falantes de língua CLIL empregando materiais atuais dos meios de comunicação e de outras fontes (MEHISTO, MARSH e FRIGOLS, 2008). Em nosso planejamento, os conteúdos, como por exemplo, sobre tipos de empresa, modelos de organograma, de anúncios de oferta de trabalho, de currículo, de documentos para solicitação de mercadorias, entre outros, foram pesquisados em site de busca pelos próprios alunos e servido de insumo para as suas próprias produções. Nesse sentido, a pesquisa em sites foi de suma importância nas aulas de CLIL, uma vez que para organizar os slides e texto das apresentações os alunos deveriam pesquisar e apresentar os resultados a partir de 3 fontes de referência disponíveis na internet.

Além de servir de insumo para a produção dos alunos, as TICs, e no nosso caso específico a internet, promoveram ao professor de LE oportunidades de elaborar o seu próprio material utilizando recursos, como notícias, documentos reais e multimídias, imagens, dados relevantes etc., disponíveis em ferramentas de busca, portais educativos, bibliotecas e enciclopédias virtuais, blogs, periódicos eletrônicos, redes sociais etc. A escola ao adotar as TICs, segundo Meireles (2010), pode disponibilizar materiais didáticos em seu site como 
recurso educacional aberto (REA); criar uma plataforma virtual de ensino e aprendizagem e permitir o acesso a recursos variados: vídeos, imagens, músicas.

As atividades com o uso das TICs para a pesquisa e para a apresentação oral de conteúdos/temas foram bem recebidas pelos alunos. Muitos reconheceram o desenvolvimento na LE e de atributos humanos (esforço, autonomia, cautela) propiciado pela preparação/apresentação dos trabalhos, apesar do nervosismo. Os excertos a seguir apresentam as impressões dos alunos durante a própria apresentação:

$\checkmark \quad$ Me senti motivado na apresentação do meu tema (Al, Aa 7)

Achei bem interessante fazer uma apresentação para a turma e ainda mais em outra lingua (A4, Aa6).

$\checkmark \quad$ (...) foi um trabalho ótimo, conseguir apresentar sozinha, um pouco nervosa mas conseguir (A3, Aa 9).

$\checkmark \quad$ Senti um frio na barriga em ter que apresentar pra turma toda sozinho (...) o tema de Logística foi bem abordada por todos, senti que a turma se esforçou para apresentar algo bem interessante e atual para todos ( $A 5$, Aa 9)

me senti bem na hora de apresentar para os demais, também tive um pouco de dificuldade em anotar referente aos outros temas apresentados. (A1, Aa 7)

Contudo, alguns alunos demonstraram dificuldades para a pesquisa na internet e também avaliaram que na tarefa de selecionar informações em grupo, no período da aula, houve pouco rendimento.

\section{$\checkmark \quad$ Senti dificuldade em pesquisar na internet (A1, Aa 2).}

$\checkmark \quad$ A aula no laboratório foi boa, mas a turma fez muito barulho, acho que com isso rendemos pouco nesse dia (A5, Aa 2)

Além das redes de informações, especialmente, o uso da internet para a pesquisa de conteúdos/temas que seriam apresentados em sala, foram mobilizadas competências digitais para o uso/manipulação de meios e recursos tecnológicos e/ou aplicações informáticas, como por exemplo, programas para a produção de slide, edição de texto e informação multimídia. $\mathrm{O}$ processo de mobilização de competências para a elaboração de slides foi também observado pelos alunos: 
Me senti motivado na apresentação do meu tema e ao mesmo tempo nervoso e cauteloso com os slides escolhidos, tive dificuldade em pesquisar as figuras e o assunto (A1, Aa 7)

Apesar do aluno (A1) sentir dificuldade na seleção das figuras e do assunto, reconhece que se sentiu motivado com a atividade e cauteloso com a preparação dos slides. Para as atividades de apresentação de conteúdo houve além do objetivo com a aprendizagem do conteúdo curricular a mobilização de competência tecnológica/informacional dos alunos. Desta forma, entendemos que as TICs podem ser ferramentas importantes em um planejamento CLIL para a busca, seleção, elaboração, difusão, criação, compartilhamento de informações por meio da interação, comunicação e colaboração entre os alunos.

Consideramos, assim, que ao relacionar CLIL e TICs, o professor oportuniza os alunos a mobilizarem conhecimentos e a tornar essa mobilização um espaço dinâmico de interação, integração entre informações (conteúdos/temas) e imagens, além de propiciar aos alunos constante atualização de informações e conhecimentos.

\section{Tarefas da vida real}

Em um planejamento CLIL por tarefas, as tarefas devem levar o aluno a vivenciar situações reais, gerando oportunidades "conversacionais significativas; que façam sentido para eles, cujos propósitos tenham relevância e criar ligação entre escola e mundo possibilitando-os vivenciar fora da sala de aula os tópicos trabalhados em sala" (GOTTHEIM, 2013). Segundo Paiva e Figueiredo (2005):

Significativo é algo que tenha a ver com o universo dos alunos. É o professor levar em consideração as experiências deles. É fazer com que os alunos produzam língua, em vez de somente reproduzi-la. Enfim, ser significativo é usar a língua de forma contextualizada.

Ao propor tarefas que usam o discurso "para" o trabalho e "sobre" o trabalho, passamos a um sistema simultâneo de agir social: estratégico-comunicativo. A comunicação, enquanto atividade interativa, manifesta aspectos constituintes desse processo pelos próprios alunos ao buscar em acordos comuns, entendimento para determinadas questões, como por exemplo, sobre a organização dos trabalhos em grupo.

As tarefas de simulação da vida real em sala de aula (entrevista de trabalho, interação entre fornecedor e cliente em uma feira de exposição etc.) com a manipulação de materiais 
autênticos foram identificadas como aspecto positivo e de grande importância para a aprendizagem, conforme ilustram os excertos a seguir:

\section{A. Simulações da vida real}

$\checkmark \quad$ Foi uma aula que todos participaram. Conseguimos falar bastante em espanhol. Fazer perguntas, responder entre todos até completar uma entrevista real. (A4, Aa5)

$\checkmark$ Achei muito interessante e até um pouco ousada a professora nos ter proposto fazer um trabalho para expor na feira, mas nos motivamos para fazer um bom trabalho. (A4, Aa6)

$\checkmark \quad$ Foi a aula mais interessante que achei pois nela pude ver que consegui me expressar melhor dentro do idioma, conseguindo passar todas as informações necessárias para os componentes do grupo, não mudaria nada também pois essa foi a aula de melhor aprendizado para mim. (Al, Aa8)

$\checkmark \quad$ Na oral ficou um pouco enrolado mais me esforcei e tentei falar, os preços também mais, a dificuldade foi mais na oral. (A2, Aa 8)

$\checkmark \quad$ Neste dia foi maravilhoso, mesmo com o nervosismo conseguimos apresentar, tudo em espanhol, errei em algumas palavras, mas é assim mesmo, é errando que se aprende. Compartilhamos todas as informações sobre cada empresa de cada grupo, muito legal conhecer um pouco de cada empresa. (A3, Aa 8)

$\checkmark \quad$ Montamos uma feira para apresentar a nossa empresa e produtos que nós oferecemos. O objetivo foi mostrar e manter diálogo com outros grupos. As aulas estão muito boas e produtivas. Estou desenvolvendo muito e estou gostando muito das aulas. (A4, Aa8)

$\checkmark \quad$ Nessa aula foi clara a dedicação da turma com os trabalhos, eles foram bem preparados e bem apresentados. Percebi que a ideia de apresentar uma feira é muito boa. Consegui apresentar e acho que falei juntamente com o grupo, muito bom. A professora deu um tempo para os grupos se conhecerem e se contatarem. Acho que deveríamos ter feito isso com mais seriedade. (A5, Aa8)

$\checkmark \quad$ O grupo se atrapalhou todo na hora de se organizar. Demoramos um pouco para arrumar as mesas, os cartazes, os produtos para expor. Ficaram todos muito bons. (A1, Aa8)

\section{B. Trabalho com materiais autênticos:}

$\checkmark \quad$ A professora entregou um catálogo do Carrefour e pediu pra escolhermos dois produtos e colher dados sobre eles para montar uma apresentação em sala de aula, conseguir fazer o 
meu tudo certinho e ainda tive a oportunidade de ler pra professora e meus colegas. (A3, Aa 9)

O tema da aula foi bem interessante, consegui fazer as atividades propostas, trabalhar com o catálogo do Carrefour em espanhol, com produtos e preços reais, foi bem legal, consegui fazer as atividades e gostei do rendimento. (A5, Aa 9)

Levar os alunos a compreenderem o uso e o sentido de (inter)agir na e pela linguagem é fundamental para que, como sujeito, este contemple seu potencial comunicativo. A possibilidade de conjugar o agir na LE (por meio das simulações da vida real) proporcionou aos alunos uma reflexão quanto à multiplicidade de conhecimentos, atitudes e valores que possuem.

Observamos, ainda, a importância de se ter um grau de dependência entre conteúdos/temas e conteúdos/temas, tarefas e tarefas. Para tanto, uma tarefa deve ter um caudal de prática, o que se aprende em uma tarefa serve para a realização da próxima tarefa e um tema é ponto de partida para desenvolver outros temas e tópicos. Essa sequenciação foi pontuada pelos alunos como um fator positivo, conforme apresentamos a seguir:

$\checkmark \quad$ Começamos as aulas com apresentação de tudo que aprendemos a nas aulas anteriores, isso ajuda muito. (A5, Aa5)

$\checkmark \quad$ Depois da feira fomos fazer contato para adquirir um produto. Tivemos que fazer um pedido e ter que fazer uma pesquisa de preço, data de entrega e forma de pagamento para adquirir um produto, que nos interessa, assim terminamos o ciclo de implementação e desenvolvimento da tão discutida empresa. (A2, Aa9)

Observamos, ainda, a necessidade de um tratamento flexível dos erros na hora das apresentações dos alunos. Em algumas apresentações houve intervenção da professora e em outras não houve, conforme observada pelos alunos:

$\checkmark \quad$ Hoje a presentei o meu trabalho com todos os meus colegas olhando pra mim e uma professora do lado como jurado e me ajudando a fala palavras que eu tive dificuldade de falar, então me ajudou bastante em quebra um pouco do meu trauma em sala de aula. (A3, Aa9) 
Não sei se o que estou falando está certo ou errado, a professora não corrige quando alguém está apresentando. Às vezes comenta um erro ou outro para alguém, mas no mais não. $(A 3, A a 5)$

Segundo Brown (2007), devemos ter cuidado especial com os erros, saber discernir a tensão ideal entre uma opinião negativa e positiva. Para isso, ele usa a metáfora de um semáforo, salientando que devemos dar muita "luz verde", a fim de encorajar o aprendiz na comunicação contínua, mas não em demasia, ao ponto de que erros cruciais passem despercebidos, chegando à fossilização. Nessa situação, "luzes vermelhas" devem chamar a atenção para esses erros. Mas, para que a retroalimentação cognitiva e afetiva possam ser ideais, o melhor é usar "luzes amarelas", oferecendo oportunidades para o aluno ajustar, alterar, reformular, esclarecer e tentar novamente.

Alguns efeitos não satisfatórios foram observados pelos alunos na aplicação do planejamento:

1. Trabalhar individualmente

2. Exposição intensiva da LE

3. Pouca explicação explícita dos elementos linguísticos

\section{Trabalhar individualmente}

O trabalho em grupo e cooperativo são algumas das caraterísticas de um planejamento CLIL. Porém, esse planejamento combinado com tarefas exigiu dos alunos momentos de produções individuais (nas tarefas possibilitadoras - TAL) para o alcance da tarefa final. E algumas dessas tarefas foram classificadas como monótonas, complicadas e confusas, não sendo bem recebidas pelos alunos, como por exemplo, as de seleção de produtos do catálogo para a preparação de $e$-mail e ordem de compra solicitando produtos para os fornecedores, conforme os excertos a seguir:

$\checkmark \quad$ Não me motivei tanto, pois achei o assunto monótono, tive dificuldades em elaborar as pesquisas dos produtos não conseguindo concluir o exercício em sala de aula, nesse gostaria que fosse mais pelo diálogo. (A1, Aa9)

$\checkmark \quad$ Foi um pouco complicado, pois tinha números e pra falar era o problema. O catálogo pra passar também para escrita meio confuso. (A2, Aa 9) 


\section{Exposição intensiva da LE}

O insumo (input) oral na L-alvo produzido pelo professor em sala de aula foi avaliado pelos alunos como excessivo, gerando dificuldades para alguns acompanharem as aulas de CLIL.

$\checkmark \quad$ No segundo dia de aula eu fiquei um pouco assustada também, por que a professora entrou na sala de aula falando tudo em espanhol, então tinha coisas que eu não conseguia acompanhar. (A3, Aa 2)

$\checkmark \quad$ Bem fiquei um pouco perdido na parte de apresentar notícias relacionadas ao mundo(...) mais conseguir, tentava falar. Poderia falar um pouco na nossa língua mesmo. $(A 2, A a 2)$

Faltou falar um pouco na nossa língua comentar um pouco mais. (A2, Aa10)

Observamos a importância do professor em um planejamento CLIL buscar formas de relacionar o insumo e a compreensão do aluno, tornado assim o "insumo compreensível" (KRASHEN, 1985). Podemos considerar que o insumo são as amostras de L-alvo que o professor proporciona aos alunos (oral ou escrita). E para que o insumo, exposto ao aluno, seja compreensível, é necessário, entre outras coisas, que professor tenha que ajustar e modificar o seu discurso em sala de aula, buscando mecanismo que facilitem a compreensão da L-alvo pelos alunos, como por exemplo, falar mais devagar, mais alto, usar sinônimos, língua materna, paráfrases, mímicas etc.

\section{Pouca explicação da LE}

Segundo alguns alunos, a explicitação de uso da LE com atividades mais direcionadas ajuda a esclarecer alguns pontos específicos:

$\checkmark$ Eu particularmente gosto de fazer mais exercícios, acredito que assim aprendo mais, mas acho bem válido a forma que a professora conduziu as aulas. (A4, Aula 10)

$\checkmark$ Faltou mais explicação. (A2, Aa9)

Assim, consideramos, também, que os aspetos linguísticos, ou seja, ter uma competência gramatical faz parte de uma competência maior, de um projeto maior para 
desenvolver uma competência de uso na L-alvo, ou seja, desenvolver uma CC que engloba outras tantas subcompetências, como a discursiva, a sociocultural e a estratégica, e que seja possível desenvolver uma CC no formato de planejamento: tarefas comunicativas + gramática como apoio. Ao ser trabalhada a parte sistêmica da língua(gem), em "momentos justificáveis, dependendo do caso, (...) em fatos problematizados a partir do uso" (ALMEIDA FILHO, 2013, p. 36), observamos pela transcrição dos alunos acima que os elementos linguísticos não foram suficientemente explicitados.

A dificuldade de ensinar gramática em um planejamento CLIL por tarefas se encontra na questão apontada por Ellis (2002, p. 22) sobre equilibrar e relacionar tais questões importantes: Quando a gramática deveria ser ensinada? Quanto de gramática, com que intensidade (em que período de tempo) a gramática deveria ser ensinada? Como deve ser ensinada? Assim, para o autor (op. cit.) o ideal é que as atividades de gramática não estejam "escondidas" em atividades comunicativas, mas que se tenha um momento em sala para sua explicitação. É o que Almeida Filho (1993) chama de "ilha de sistematização". E, em nossa pesquisa, elas foram insuficientes, segundo os alunos.

Foi possível, ao longo desse capítulo de análise, verificar as implicações e os efeitos do planejamento CLIL por tarefas para o ELFE na EPT. Buscamos, ainda, identificar se o planejamento atendeu às expectativas dos alunos e esses se sentiram motivados a dar continuidade aos estudos de espanhol. (71,4\%) dos alunos afirmaram que se sentiram mais motivados para dar continuidade a aprendizagem da língua espanhola e $(57,1 \%)$ afirmaram que terminam o curso com suas expectativas correspondidas.

Apesar de o planejamento CLIL ser um sistema dual de aprendizagem (Integrando conteúdo/temas e língua), a percepção final dos alunos quanto ao desenvolvimento da CC é mais evidente que o desenvolvimento da FI. Na avaliação final, os alunos descrevem o resultado do processo final do curso em termos de aprendizagem da LE (desempenho). Apesar de não termos utilizado descritores de avaliação, os alunos descrevem seu desempenho na perspectiva de "ser capaz de" (BORGES-ALMEIDA, 2011) muito utilizado como descritor para a avaliação de nível de proficiência no Quadro Europeu Comum de Referência.

$\checkmark$ Com os resultados, acredito que agora consigo me virar bem e conversar em espanhol. (A4, aula 10)

$\checkmark$ Nesse curso consegui absorver de tudo um pouco da escrita até a conversação, o método utilizado para ensino foi muito bom. (A1, Aal0)

$\checkmark$ Hoje eu sei pelo menos o básico de espanhol. (A3, Aa10) 
$\checkmark$ Tive um bom desempenho. Mais na fala, antes não falava nada, Me surpreendi quando me perguntava coisas e eu respondia, principalmente no dia da feira e na entrevista de trabalho. (QFA)

$\checkmark$ Percebi que posso entender assuntos grandes. (QFA)

$\checkmark \quad$ No geral estou muito orgulhosa de mim por ter aprendido muitas coisas em espanhol como pronuncia, entendimento da língua. (QFA)

$\checkmark$ Mas me desenvolvi bastante durante este curso consegui me soltar mais, e até consegui falar um pouco de espanhol. (QFA)

$\checkmark$ Faltou um pouco de desempenho na parte oral e escrita. (QFA)

Além de avaliarem o que consideraram ser capazes de realizar na LE, inferiram que o instrumento de autoavaliação pode, também, contribuir para o (re)fazer do ato docente.

\section{$\checkmark \quad$ A base nos foi dada, cabe a nós absorvê-la da melhor forma (...) espero que tenha contribuído em algo para as próximas aulas. (A5, Aula 10)}

Algumas das caraterísticas do planejamento CLIL, como por exemplo, o uso de conteúdos/temas relevantes e de interesse dos alunos, tarefas da vida real com simulações e uso de material autêntico, ambiente cooperativo, interação ente os alunos, a negociação de significado, geraram motivação nos alunos, que por sua vez, promoveram esforço, um correr risco, participação, autonomia, engajamento, comprometimento e reponsabilidade dos alunos, atitudes geradas pelo próprio formato do planejamento proposto e também por aspectos individuais dos próprios alunos que por sua vez se relacionam à motivação intrínseca.

As escolhas pedagógicas, decorrentes da própria natureza da proposta CLIL por tarefas, e as atitudes geradas por essas escolhas tiveram o potencial de propiciar o desenvolvimento de competências dos alunos para a formação profissional e cidadã na, pela e para a língua(gem). Além disso, o planejamento proposto propiciou aos alunos:

$\checkmark$ Oportunidades para a aprendizagem significativa da LE por meio de trocas comunicativas relevantes para o agir direcionado a obter resultados e a obter entendimentos e acordos;

$\checkmark$ Motivação e expectativas futuras em relação à aprendizagem da LE e por novas temáticas, corroborando a ideia de que os alunos estão dispostos a saberem mais; 
$\checkmark$ Maior participação do grupo com relatos de experiências (pessoais e profissionais) de forma voluntária;

$\checkmark$ Desenvolvimento da alteridade e da tolerância à diversidade de opiniões;

$\checkmark$ Fomento à autoavaliação, autorreflexão sobre valores e atitudes adotadas pelo aluno socialmente no cotidiano e no mundo do trabalho;

$\checkmark$ Reconhecimento dos alunos sobre suas próprias competências para trabalhar em equipe, bem como o aumento da consciência da importância de trabalho em equipe que é um dos atributos de um perfil pessoal e profissional contemporâneo;

$\checkmark$ Aumento da corresponsabilidade no processo de ensinar e aprender;

$\checkmark$ Percepção dos alunos quanto à multiplicidade de conhecimentos, atitudes e valores que possuem.

E, ao professor:

$\checkmark$ Fornecimento de diferentes insumos para desencadear temas: filmes, vídeos, músicas etc., considerados, também, como elementos motivacionais pelos alunos;

$\checkmark$ Uso das TICs para ampliação de fontes de insumos/atividades autênticas de uso social e contemporâneo.

As percepções dos alunos sobre o processo de desenvolvimento de competências em termos de atributos humanos e LE se tornaram um elemento importante para a conscientização sobre o que precisam melhorar e quais são seus potenciais como profissional (pré-serviço e em serviço), como pessoa e como aprendente de LE. 


\section{CAPÍTULO 5 - CONSIDERAÇÕES FINAIS}

Um texto interminável

\subsection{PRINCIPAIS CONTRIBUIÇÕES DA PESQUISA}

O ensino CLIL (conteúdos/temas e língua) combinado com tarefas permitiu reflexões e discussões sobre o nosso posicionamento e nossas atitudes frente à sociedade (empresa, serviços, pessoas etc.). Ao buscar a articulação entre a teoria e a prática das rel(ações) profissionais e pessoais - cotidianas, entre patrão/empregado, clientes/fornecedor, consumir/serviços etc., valores, conhecimentos e competências foram mobilizadas fomentando assim o desenvolvimento de uma formação cidadã e profissional.

Nessa combinação (conteúdos/temas e tarefas), a LE utilizada como instrumento educacional, promoveu o acesso e a interação com as informações disponíveis e com os conhecimentos produzidos no, para e pelo desenvolvimento de uma competência de uso. É, portanto, a partir de uma competência de uso na L-alvo que podemos participar da construção de significados reais na sociedade. Sendo assim, a estrutura da língua, a ação comunicativa e a construção de significados em sociedade são elementos que se tornam complementares.

Além dos alunos serem levados a desenvolver a CC com ações estratégicas e comunicativas no "mundo da vida" (HABERMAS, 2012) foram simultaneamente levados a analisar criticamente aspectos da vida profissional e pessoal. Segundo Rajagopalan (2015, informação verbal ${ }^{52}$ ) ser crítico é acima de tudo uma postura. Criticar é tomar posição contrária, separar, decidir. Ajusta, portanto com o nosso entendimento em Habermas (op. cit.) sobre o agir comunicativo na busca de uma via de entendimento, pois ser crítico (RAJAGOPALAN, op. cit.) é estar aberto a possibilidades e para isso se postulam posições binárias, dicotômicas.

A busca do senso crítico ou percepção crítica sobre problemas cotidianos e da própria sociedade sempre fez parte do sujeito. Transportar essas necessidades e materializá-las em sala de aula didaticamente, talvez seja a maior dificuldade, e entendemos que o planejamento CLIL pode ser uma entre outras possibilidades exploradas para o alcance desse objetivo, uma vez que

\footnotetext{
52 RAJAGOPALAN, Kanavillil. Colóquio Conversas com Estudiosos da Linguagem intitulado Linguística Aplicada Crítica: Avanços, Desafios, Criticidade e seus Critérios. Brasília: NECAL — Núcleo de Estudos Críticos e Avançados em Linguagem do Programa de Pós-Graduação em Linguística da Universidade de Brasília, em 5 de maio de 2015.
} 
os temas estão a serviço da comunicação por meio da interação com o mundo, com o eu e com as pessoas. Utilizamos o planejamento CLIL combinando com o ensino por tarefas, porém o planejamento CLIL pode ser utilizado, ainda, em combinação com outros tipos de planejamentos de cursos, como por exemplo, o ensino por projetos, por estudos de casos, por gêneros, por teatro etc., as possibilidades não se esgotam na tentativa de buscarmos planejar cursos que tenham um caráter motivacional para os alunos, levando-o a uma aprendizagem significativa.

A sala de aula é uma extensão da vida e faz parte de um contexto sociocultural e, nesse sentido, é importante buscarmos formas do aluno se sentir motivado a aprender dentro e mesmo fora dela. O planejamento CLIL por tarefas possibilitou essa motivação e expectativas futuras dos alunos para a aprendizagem de E/LE, ao conferir a importância da LE para (con)vivência social e ao focar o que é relevante e significativo para o aluno como profissional e cidadão.

Além disso, o planejamento proposto possibilitou o desenvolvimento da autonomia do aluno para que possa buscar competências gerais e profissionais de uso real da L-alvo, uma vez que a formação de opinião, por meio de conteúdos/temas e o entendimento do sujeito como cidadão são processos contínuos e têm relação direta com a sua participação fora da sala de aula. Trabalhar, portanto, com a aprendizagem integrada de conteúdos/temas e língua no processo de ELFE na EPT de nível técnico subsequente é uma forma de vivenciar a concepção de educação integral, onde a educação geral se torna parte inseparável da educação profissional.

Desenvolver competências necessárias para comunicar-se, que neste contexto requer o desenvolvimento de múltiplas habilidades em níveis de saberes/conhecimentos e língua combinadas com o desenvolvimento de atitudes e valores é reconhecer o aluno como cidadão e profissional. Para tanto, no planejamento CLIL o desenvolvimento de uma competência não desconsidera a outra.

São reconhecíveis, portanto, dois objetivos importantes ao tratar do ensino de línguas na formação profissional de nível técnico: o agir estratégico e o comunicativo (HABERMAS, 2012), simultaneamente, numa relação estrita entre os objetivos do aluno, demandas do mercado de trabalho e da sociedade. Na medida em que se desenvolviam competências "funcionais", estratégicas-instrumentais para "saber lidar" em determinadas situações de trabalho foi possível despertar o aluno para questões críticas de uso da própria língua(gem), intepretações de situações, valores e atitudes. Assim, o desenvolvimento concomitante de competências para lidar em determinadas situações profissionais "previsíveis" de uso da língua e o de competências para atuar como cidadão autônomo e crítico foi possível em um planejamento CLIL por tarefas. 
A relevância da pesquisa se centra no caráter investigativo que só foi possível por meio de uma reconstrução de dados levantados para a configuração da proposta CLIL na EPT e a avaliação do efeito desse planejamento no processo, a partir da percepção dos alunos. Além disso, ao trabalhar com essa proposta, abrimos possibilidades para o mapeamento de necessidades e interesses de outros eixos tecnológicos, atendendo a outros contextos com diferentes conteúdos/temas e tarefas, e ainda repensar a nossa prática docente e a realização de novos planejamentos de curso e/ou replanejamentos.

A realização de pesquisa-ação na área de AELin auxilia, assim, o professor-pesquisador no reconhecimento de possíveis mudanças nas dimensões ou materializações do ato de ensinar, em nossa pesquisa, o ato de ensinar LE em um contexto adverso (alunos trabalhadores, com pouco contato ou experiência na L-alvo, de curso noturno e de turma heterogênea). Esse tipo de contexto apresenta, principalmente na EPT, (des)encontros entre as expectativas dos estudantes, dos professores, da instituição, do mercado de trabalho e as reais possibilidades de ensino e aprendizado de uma LE, frente às abordagens que concorrem nesse contexto quanto às decisões do currículo, da carga horária etc.

Embora a análise de abordagem ${ }^{53}$ (ALMEIDA FILHO, 2009, 2010) (sua descrição, teorização) não tenha sido o objeto deste trabalho, a pesquisa-ação, com a descrição e análise do processo de ensino e aprendizagem com momentos do retorno (retroalimentação) dos estudantes sobre esse processo, se tornou uma ferramenta válida de reflexão sobre a nossa abordagem de ensinar.

Os estudos acadêmicos do professor e sua aplicação (competência teórica e competência aplicada) nem sempre são suficientes para garantir uma competência profissional, que pode ser mobilizada por meio de uma pesquisa-ação, pois é na sala de aula, na práxis e no processo de reflexão que buscamos o aprimoramento profissional como docentes de línguas.

Barçante (2014), ao trazer evidências da pesquisa inicial sobre competências de ensinar, retoma Alvarenga (1999) que conclui "haver uma relação de precedência da competência profissional sobre as demais competências" (p. 208) e a considera "macro-dinamizadora das relações que ocorrem entre as competências” (p. 222), sendo assim, a competência profissional é, em sua essência, uma ação reflexiva, espiralizada, em movimento, ou, conforme Wallace

\footnotetext{
53 Almeida Filho $(2009,2010)$ apresenta como proposta para essa formação reflexiva do professor o desenvolvimento de um procedimento de análise de uma aula típica gravada e transcrita ou parcialmente transcrita chamado de análise de abordagem. $\mathrm{O}$ analista de abordagem pode ser o próprio professor que se analisa ou qualquer outra pessoa que tenha uma crescente consciência crítica sobre as vertentes formadoras da abordagem e queira ajudar este professor.
} 
(1991, p. 58) "um horizonte" que "nunca é finalmente alcançado". O que movimenta esse espiral, essa busca por novos horizontes, "novas travessias" é o "desassossego" docente que é interminável.

\subsection{LIMITAÇÕES DA PESQUISA APONTANDO PROPOSTAS DE TRABALHOS FUTUROS}

- O planejamento CLIL ressalta a importância do professor na identificação dos estilos de aprender dos alunos e na fomentação do desenvolvimento das estratégias de aprendizagem. Entendemos que esses dois aspectos são de grande relevância, pois ao descobrir o seu estilo próprio, os alunos podem ser capazes de escolher as estratégias que melhor abordam o problema ou tarefa proposta pelo planejamento. Entretanto, pelas limitações de espaço neste trabalho, trataremos dessas temáticas em trabalhos futuros.

- As estratégias de comunicação no discurso do professor em sala de aula podem ser consideradas também um importante objetivo de estudo para o planejamento CLIL, uma vez que houve entre os alunos queixas quanto à dificuldade para o acompanhamento das aulas devido à exposição excessiva da LE. Porém, entendemos que nas aulas de CLIL a exposição excessiva e/ou intensiva em LE não seja o impedimento para que o aluno acompanhe as aulas, mas sim a dificuldade do professor em utilizar estratégias comunicativas adequadas, por isso consideramos que uma atenção especial em estudos futuros pode ser dada a essas estratégias.

- A literatura sobre autoavaliação salienta a importância do professor envolver os alunos na criação, definição de critérios pessoalmente significativos para eles, o que pode favorecer o aumento e diversificação de padrões em sala de aula e personalização da aprendizagem para aquele grupo (BRUCE, 2006), e apesar de considerarmos sua relevância tais premissas só foram reveladas no decorrer da análise e de novas leituras, não sendo consideradas no planejamento. Para pesquisas futuras entendemos que os critérios de autoavaliação deverão ser mais bem definidos.

- Quanto à análise de necessidades da situação-alvo, no caso específico de nossa pesquisa - da área de Logística, o levantamento foi conduzido entre profissionais da área por meio de amostragem de conveniência e não probabilística, baseada na acessibilidade e disponibilidade da população, não podendo desse modo garantir a representatividade dos resultados com

\footnotetext{
${ }^{54}$ GUIMARÃES ROSA (1983).
} 
relação às necessidades de uso da LE pela área abordada, requerendo, também, outras formas de levantamento de dados. Seria viável, ainda, para a análise da situação-alvo, levantar conteúdos e temas trabalhados pelos docentes da área técnica durante o semestre, de forma a tonar a aprendizagem mais significativa e contextualizada para os alunos. 


\section{REFERÊNCIAS}

ALMEIDA FILHO, J.C.P. O Conceito de Nível Limiar no Planejamento da Experiência de Aprender Línguas. In: ; LOMBELlO, L.C (Org.). O Ensino de Português para Estrangeiros: Pressupostos para o Planejamento de Cursos e Elaboração de Materiais. Campinas: Pontes Editores, 1989.

Dimensões Comunicativas no Ensino de Línguas. 7. ed. Campinas: Pontes, 2013. Edição Comemorativa - 20 anos. (1.ed. 1993)

Aprendizagem e Ensino de Línguas em Contextos Tecnológicos. Reverte: Revista de Estudos e Reflexões Tecnológicas da Fatec Indaiatuba, Indaiatuba, v. 6, 2008.

A abordagem orientadora da ação do professor. In: (Org.) Parâmetros Atuais para o Ensino de Português/LE. Campinas: Pontes, 2009a. $2009 b$.

Linguística Aplicada: Ensino de Línguas e Comunicação. 3. ed. Campinas: Pontes,

Auto-análises de abordagem e de competências na formação continuada intensiva de professores de línguas. In: SILVA, K. A. (Org.) Ensinar e aprender línguas na contemporaneidade: linhas e entrelinhas. Campinas: Pontes, $2010 \mathrm{~b}$.

Fundamentos de Abordagem e Formação no Ensino de PLE e de outras línguas. Campinas, SP: Pontes, 2011.

Quatro Estações no Ensino de Línguas. Campinas: Pontes, 2012.

; BARBIRATO, R. C. Ambientes Comunicativos para Aprender Língua Estrangeira. Trabalhos em Linguística Aplicada. Campinas, v. 36, p. 23-4, 2000.

; SOUTO FRANCO, M. M. O conceito de competência comunicativa em retrospectiva e perspectiva. In: Revista Desempenho v. 10, n. 1, jun/2009. Universidade de Brasília. Brasília, 2009.

AlvarengA, M. B. Configuração de Competências de um Professor de Língua Estrangeira (Inglês): implicações para a formação em serviços. Tese (Doutorado em Linguística Aplicada) - Instituto de Estudos da Linguagem, Universidade Estadual de Campinas, Campinas, 1999.

. Competências de Ensinar Analisadas Durante o Período de Estágio Supervisionado: Ações Paralelas e Conjuntas para Formação de Professores de Inglês. In: VIEIRAABRAHÃO, M.H. (Org.). Prática de Ensino de Língua Estrangeira: Experiências e Reflexões. Campinas: Arte Língua e Pontes, 2004.

Configuração da abordagem de ensinar de um professor com reconhecido nível teórico em Linguística Aplicada. In: ALMEIDA FILHO, J.C.P. (Org.). O professor de língua estrangeira em formação. 3. ed. Campinas: Pontes, 2009, p.111-125. 
; BACELLAR, F. Construindo Competências sobre e com o Livro Didático de Inglês. In: ALVAREZ, M. L. O.; SILVA, K.A. (Org.). Linguística Aplicada: múltiplos olhares. Campinas e Brasília: Pontes e Finatec, 2007, p. 141-154.

ANTHONY, E. M. Approach, Method and Technique. English Language Teaching, vol 17, 1963.

AUGUSTO, E. H. Ensino instrumental na língua-alvo: uma proposta de ensino da escrita em ambiente acadêmico. Dissertação (Mestrado em Linguística Aplicada) - Instituto de Estudos da Linguagem, Universidade Estadual de Campinas, Campinas, 1997.

AUGUSTO-NAVARRO, E. H. Necessidades e Interesses Contemporâneos no EnsinoAprendizagem de Inglês para Propósitos Específicos. In: SILVA, K. A; ALVAREZ, M. L. O. Perspectivas de Investigação em LA. Campinas: Pontes, 2008.

$73,2012$.

; et al. Revisitando necessidades, interesses e motivação. Contexturas, v. 19, p. 51-

AUSUBEL, D.P. Aquisição e retenção de conhecimentos: uma perspectiva cognitiva. Lisboa: Plátano Edições Técnicas, 2003.

BACHMAN, L. Fundamental Considerations in Language Testing. Oxford: Oxford University Press, 1990.

BARBIER, R. A. Pesquisa-Ação. Tradução de Lucie Didio. Brasília: Liber, 2007.

BARBIRATO, R. C. A tarefa como ambiente para aprender LE. Dissertação (Mestrado) Universidade Estadual de Campinas, Unicamp, 1999.

Tarefas geradoras de insumo e qualidade interativa na construção do processo de aprender LE em contexto inicial adverso. Tese (Doutorado) - Instituto de Estudos da Linguagem, Universidade Estadual de Campinas, Campinas 2005.

Planejamentos Temáticos Baseados em Tarefas: focalizando a comunicação na sala de aula. In: SILVA, K. A. e ALVAREZ, M. L. O. Perspectivas de Investigação em LA. Campinas: Pontes, 2008.

.; CASSOLI, E.R. O desenvolvimento da competência linguístico comunicativa de alunos de trás em cursos temáticos baseado em tarefas. Horizontes de Linguística Aplicada, ano 12, n. 1, 2013.

BARÇANTE, M. Competências de ensinar: evidencias da pesquisa inicial. In: ALMEIDA FILHO, J.C.P.(Org.) Competências de Aprendizes e Professores de Línguas. Campinas: Pontes, 2014.

BELTRÁN, B. A. Enfoque, metodología y orientaciones didácticas de la enseñanza del español con fines específicos. In: Carabela , v. 44, monográfico. La enseñanza del español como lengua extranjera con fines específicos. Madrid: SGEL, p. 5-29, 1998. 
La enseñanza del español con fin es profesionales. En: Vademécum para la formación de profesores: enseñar español como segunda lengua (L2) /lengua extranjera (LE). Madrid: SGEL, 2004.

Aprendizaje y enseñanza con fines específicos: comunicación en ámbitos académicos y profesionales. Madrid: SGLE, 2012.

BERGER, R. L. F. Formação baseada em competências numa concepção inovadora para a formação tecnológica. In: CONGRESSO DE EDUCAÇÃO TECNOLÓGICA DOS PAÍSES DO MERCOSUL, 5, 1998, Pelotas. Anais... Pelotas: ETF-Pel, 1998.

BEZERRA, D.S. Políticas e planejamento do ensino médio (integrado ao técnico) e da língua estrangeira (inglês): na mira(gem) da politecnia e da integração. Tese (Doutorado em Educação) - Faculdade de Educação, Universidade de São Paulo, São Paulo, 2012.

BIZÓN, A. C. C. Aprender conteúdos para aprender língua estrangeira: uma experiência de ensino alternativo de PE. In: ALMEIDA FILHO, J. C.; LOMBELLO, L. (Orgs). Identidades e Caminhos no Ensino de português para estrangeiros. Campinas, SP: Pontes, 1992.

Características da interação em contexto de ensino regular e em contexto de Campinas. Dissertação (Mestrado em Linguística Aplicada) - Instituto de Estudos da Linguagem, Universidade Estadual de Campinas, Campinas, 1994.

BLATYTA, D. F. Mudança de habitus e teorias implícitas - uma relação dialógica no processo de educação continuada de professores. In: ALMEIDA FILHO, J. C. P. (Org.). O professor de língua estrangeira em formação. Campinas: Pontes, 1999, p. 63-81.

BOGDAN, R; BIKLEN, S. K. Investigação qualitativa em educação: uma introdução à teoria e aos métodos. Porto, Portugal: Editora Porto, 1994.

BORGES-ALMEIDA, V. Com a palavra, o aluno formando em Letras: percepções sobre proficiência oral e avaliação da produção oral. In: BERGSLEITHNER, J.M.;

WEISSHEIMER, J.; MOTA, M. B. (Org.). Produção oral em LE: múltiplas perspectivas. 1ed.Campinas: Pontes, 2011, p. 129-152.

BOURDIEU, P. Razões práticas: Sobre a teoria da ação. Campinas: Papirus, 1996.

MEC/SETEC. Catálogo Nacional de Cursos Técnicos. Brasília, 2012.

BRASIL, P. C. S. ¿Piedras en el camino? ¿Construyamos un castillo! Necessidades e interesses de aprendizes de espanhol de um curso técnico integrado. Dissertação (Mestrado em Linguística Aplicada) - Instituto de Letras, Departamento de Línguas Estrangeiras e Tradução, Universidade de Brasília, Brasília 2013.

BRASIL. Senado Federal. Lei de Diretrizes e Bases da Educação Nacional. Lei nº 9394/96, de 20 de dezembro de 1996.

Presidência da República. Lei 11.741, de 16 de julho de 2008. Altera dispositivos da Lei 9.394, de 20 de dezembro de 1996. 
BRASIL. Ministério da Educação. Conselho Nacional de Educação. Parecer CNE/CEB no 16/99, aprovado em 05 de outubro de 1999. Diretrizes curriculares nacionais para a Educação Profissional de Nível Técnico. 1999a

Resolução CNE/CEB no 04/99, de 5 de outubro de 1999. Institui as Diretrizes Curriculares Nacionais para a Educação Profissional de Nível Técnico, baseada no Parecer CNE/CEB, no 16/99, de 5 de outubro de 1999. 1999b

\section{.MEC.SETEC. Diretrizes Curriculares Nacionais para a Educação Profissional} Técnica de Nível Médio em Debate. PROEP. Brasília, setembro, 2000.

Presidência da República. Decreto 5.154, de 23 de julho de 2004. Regulamenta o § 2o do artigo 36 e os artigos de 39 a 41 da Lei 9.394, de 20 de dezembro de 1996, que estabelece as diretrizes e bases da educação nacional e dá outras providências. 2004a

. Ministério da Educação. Secretaria de Educação Profissional e Tecnológica. Proposta em discussão. Políticas públicas para a educação profissional e tecnológica. Brasília, MEC, abril/2004b.

Resolução CNE/CEB no 4, de 27 de outubro de 2005: inclui novo dispositivo à Resolução CNE/CEB 1/2005, que atualiza as Diretrizes Curriculares Nacionais definidas pelo Conselho Nacional de Educação para o Ensino Médio e para a Educação Profissional Técnica de nível médio às disposições do Decreto $n^{\circ}$ 5.154/2004. 2005.

Resolução no 1, de 3 de fevereiro de 2005: Atualiza as Diretrizes Curriculares Nacionais definidas pelo Conselho Nacional de Educação para o Ensino Médio e para a Educação Profissional Técnica de nível médio às disposições do Decreto $n^{\circ}$ 5.154/2004; Parecer CNE/CEB nº.39/2004 - Atualiza DCN para a Educação Profissional. 2005.

Conselho Nacional de Educação. Resolução CNE/CEB nº. 01/05. Atualiza as diretrizes curriculares nacionais para o ensino médio e educação profissional técnica de nível médio às disposições do decreto federal 5.154/2004.

Manual do Candidato ao Exame Celpe-Bras. Brasília, Secretaria de Educação Superior (SESu), MEC, 2006.

Documento base. Educação Profissional Técnica de Nível Médio Integrada ao Ensino Médio. Brasília, 2007a.

. Ministério da Educação. Documento Base do Programa de Integração da

Educação Profissional Técnica de Nível Médio Integrada ao Ensino Médio na Modalidade de Educação de Jovens e Adultos (Proeja). Brasília: MEC/ Setec, 2007b.

Parecer CNS/CES n⿳ 101/2007. Consulta sobre a oferta de disciplinas isoladas pelas instituições de ensino superior e a normatização do art. 50 da LDB, 2007c.

Lei $\mathbf{n}^{\mathbf{0}}$ 11.892, de 29 de dezembro de 2008. Institui a Rede Federal de Educação Profissional, Científica e Tecnológica, cria os Institutos Federais de Educação, Ciência e Tecnologia, e dá outras providências. Brasília, 2008. 
CNE/CP. Parecer $\mathbf{n}^{\mathbf{0}}$ 11, de 30 de outubro de 2009. Proposta de experiência curricular inovadora do Ensino Médio.

.MEC.SETEC. Diretrizes Curriculares Nacionais para a Educação Profissional Técnica de Nível Médio em Debate. Texto para discussão. Brasília, 2010.

MEC/ SETEC. Instituto Federal de Educação, Ciência e Tecnologia: Um novo modelo em educação Profissional e tecnológica - Concepções e diretrizes. 2010.

Parecer CNE/CEB. Atualização das Diretrizes Curriculares Nacionais para a Educação Profissional Técnica de Nível Médio. Brasília: CNE.CEB, 2011.

MEC. Parecer CNE/CEB. Resolução n. 2, de 30 de janeiro de 2012. Define Diretrizes Curriculares Nacionais para o Ensino Médio. Brasília: CNE.CEB, 2012.

Resolução n 6, de 20 de setembro de 2012: Define Diretrizes Curriculares Nacionais para a Educação Profissional Técnica de nível médio, 2012.

Decreto no 8.268/2014 - Qualificação Profissional, inclusive Formação Inicial e Continuada de Trabalhadores. 2014.

BRINTON, D. Content-based instruction: reflecting on its applicability to the teaching of Korean. 12 Annual Conference American Association of Teachers of Korean. Chicago: Illinois, 2007

BRINTON, D.M.; SNOW, M.A; WESCHE, M.B. Content-based Second Language Instruction. Boston: Heinle and Heinle, 1989.

BROWN, H. D. Principles of Language Learning and Teaching. 5a. ed., New York: Longman, 2007.

CANALE, M. From communicative competence to communicative language pedagogy. In: Richards, J.; Schmidt, R. (Org.). Language and communication. London: Longman, 1983.

. SWAIN, M. Theoretical bases of communicative approaches to second language teaching and testing. Applied Linguistic, 1980.

CARDOSO, R. de C.T. O imaginário do comunicativismo de professores de língua inglesa do ensino médio e fundamental. Tese (Doutorado em Letras) - UNESP/Assis, São Paulo, 2002.

CELANI, M. A. A. Revivendo a aventura: desafios, encontros e desencontros. In: RAMOS, R. C. G. e FREIRE, M. M. (Orgs.) A Abordagem Instrumental no Brasil: um projeto, seus percursos e seus desdobramentos. Campinas, SP: Mercado de Letras; São Paulo: EDUC, 2009.

CELCE -MURCIA, M. Rethinking the Role of Communicative Competence. In SOLER, E. A.; JORDÀ, M. P. S. Intercultural Language Use and Language Learning. Kindle ed. [S.1.]: Springer, 2007. 
CHAGAS, V. Didática especial de línguas modernas. São Paulo: Companhia Editora Nacional, 1979.

CHAUI, M. Convite à filosofia, São Paulo Ática, 1999.

CHRISTOPHE, M. A legislação sobre a educação tecnológica no quadro da educação profissional brasileira. IETS: Rio de Janeiro, 2005.

CHURCHES, A. Taxonomía de Bloom para la era digital. 2009. Disponível em: <http://edorigami.wikispaces.com>. Acesso em: 05 de agosto de 2015.

CIAVATTA M.; RAMOS, M. Ensino Médio Integrado: concepção e contradições. São Paulo: Cortez, 2005.

COYLE, D. Relevance of CLIL to the European Commission's Language Learning Objectives. In: MARSH, D. (ed). CLIL/EMILE - the European Dimension, Public Services Contract DG EAC, 27- 28, 2002

COYLE, D. Content and Language Integrated Learning Motivating Learners and Teachers. Scottish Languages Review, 13, 1-18, 2006.

CRANDALL, J.A. Content-Centered MARSOLanguage Learning. ERIC Digest. ERIC Clearinghouse on Languages and Linguistics Washington DC, p.1-7, 1994

CRESWELL, J. W. Projetos de pesquisa: métodos qualitativo, quantitativo e misto. Tradução Magda Lopes. 3. ed. Porto Alegre: Artmed, 2010.

DALMÁS, A. Planejamento Participativo na Escola: elaboração, acompanhamento e avaliação. Petrópolis, RJ: Vozes, 1999.

DAMIÃO, S. M. Course design, action research and the use of computers: challenges in an ESP course. Revista Brasileira de Linguística Aplicada, Belo Horizonte, v. 11, n. 4, p. 913 934, 2011.

DELLA ROSA, S. F. P. Análise das Reflexões Estabelecidas por Pesquisadores entre Conhecimento de Língua Inglesa e Desempenho Acadêmico. Dissertação (Mestrado). Universidade Federal de São Carlos, 2013.

DEWEY, J. Vida e educação. 9. ed. São Paulo: Melhoramentos, 1975.

DÖRNYEI, Z. Motivação em ação: buscando uma conceituação processual da motivação de alunos. In: BARCELOS, A. M. F. (Org.) Linguística aplicada: reflexões sobre ensino e aprendizagem de língua materna e língua estrangeira. Campinas: Pontes, 2011. p. 199-236.

DUDLEY-EVANS,T; ST.JOHN,M.J Developments in English for Specific Purposes :a multi-disciplinary approach. Cambridge: Cambridge University Press, 1998.

DUEÑAS, M. V. Acquiring cultural knowledge through content-enriched instruction.

Babylonia, 3. 2002, p. 58-62. 
EL ANDALOUSSI, K. Pesquisa-ações: ciências, desenvolvimento, democracia. São Carlos, São Paulo: Eduscar, 2004.

ELLIS, R. The place of Grammar instruction in the Second/Foreign language curriculum. In: HINKEL, E.; FOTOS, S. (Ed.).New Perspectives on Grammar Teaching in Second Language Classrooms. Mahwah, New Jersey, Lawrence Erlbaum Associates, 2002. p. 1734.

ESTAIRE, S. El diseño de una unidad didáctica a través de tareas. Cable, n. 5 e RedELE: revista electrónica de didáctica/español como lengua extranjera, n. 1,1990.

Tareas para Hacer Cosas en Español: Principios y Práctica de la Enseñanza de Lenguas Extranjeras mediante Tareas. Madrid: Colección Aula de Español, Universidad Antonio de Nebrija, 1999.

Tareas para el desarrollo de un aprendizaje autónomo y participativo. In: ZANÓN, J. (coord.) La enseñanza del español mediante tareas. Madrid: Edinumen, 1999.

Un instrumento para planificar clases. Didactired, Centro Virtual Cervantes, 2000.

; ZANÓN, J. El diseño de unidades didácticas mediante tareas: principios y desarrollo. Comunicación, Lenguaje y Educación, v. 7, 1990.

FLICK, U. Introdução à pesquisa qualitativa. Tradução Joice Elias Costa. 3. ed. Porto Alegre: Artmed, 2009.

FRANCO, M. C. Formação de professores para a educação profissional e tecnológica: perspectivas históricas e desafios contemporâneos. In: INEP. Formação de professores para educação profissional e tecnológica. Coleção Educação Superior em Debate, v. 8. Brasília: Instituto Nacional de Estudos e Pesquisas Educacionais Anísio Teixeira, 2008.

FRANCO, M. S.; ALVARENGA, M. B. Mapeamento do perfil do(a) professor(a) de inglês das escolas públicas das de Piracicaba: formação e competências, 2007.

FREIRE, P. Pedagogia da autonomia: saberes necessários à prática educativa. São Paulo: Paz e Terra, 1996.

FRIGOTTO, G.; CIAVATTA, M.; RAMOS, M. (Orgs). Ensino Médio Integrado: concepção e contradições. 3. ed. São Paulo: Cortez, 2012.

CIAVATTA, Maria (Org.). Ensino médio: ciência, cultura e trabalho. Brasília: MEC/SEMTEC, 2004.

GIBBS, G. Análise de dados qualitativos. Porto Alegre: Artmed, 2009.

GIL, A. C. Como elaborar projetos de pesquisa. 5 ed. São Paulo: Atlas, 2010.

GIROUX, H. A. Os professores como intelectuais: rumo a uma pedagogia crítica da aprendizagem. Porto Alegre: Artes Médicas, 1997. 
GLOSSALA. Projeto Glossário Eletrônico de Linguística Aplicada (GLOSSALA).

Desenvolvido pelo Programa de Pós-graduação em Linguística Aplicada da Universidade de Brasília - PPGLA e coordenado pelo Professor Pesquisador José Carlos Paes de Almeida Filho Disponível em: < http://glossario.sala.org.br/ $\geq$. Acesso em: 05 de agosto de 2015.

GÓMES DE ENTERRÍA, P. El lenguaje científico-técnico y sus aplicaciones didácticas. In: Carabela, v. 44, Monográfico. La enseñanza del español como lengua extranjera con fines específicos. Madrid: SGEL, p. 30-39, 1998.

GOTTHEIM, L. A Gênese de um material didático para o ensino de língua. PEREIRA, A. L.; GOTTHEIM, L. (Org.). Materiais didáticos para o ensino de língua estrangeira: processos de criação e contextos de uso. Mercado de Letras, 2013.

GUIMARÃES, R. M.; Open file: in search of an ideal teaching performance. São Paulo: Editora SENAC, 1995.

GUIMARÃES, R. M.; BARCANTE, M.; SILVA, V.C. A natureza do Ensino de Línguas para Fins Específicos (ELFE) e as possibilidades de aquisição/aprendizagem de línguas.

Contexturas: Ensino crítico de inglês, APLIESP, São Paulo, v. 23, p. 62-80, 2014.

; BARCANTE, M. Língua estrangeira no currículo da educação profissional e sua relação com o mercado de trabalho. In: SEMINÁRIO NACIONAL DE EDUCAÇÃO PROFISSIONAL E TECNOLÓGICA, 4, 2014, Belo Horizonte. Anais... Belo Horizonte: CEFET-MG, 2015, p. 1-15.

GUIMARÃES ROSA, J. Grande sertão: veredas. São Paulo: Abril Cultural, 1983.

HABERMAS, J. Consciência moral e agir comunicativo. Rio de Janeiro: Tempo Brasileiro, 1989.

Soberania como procedimento: um conceito normativo de espaço público. Novos Estudos, São Paulo: CEBRAP, n. 26, p. 100-113, mar.1990.

Teoria do agir comunicativo 1: racionalidade da ação e racionalização social. Tradução de Paulo Astor Soethe; revisão da tradução Flávio Beno Siebeneichler. São Paulo: Editora WMF Martins Fontes, 2012.

Teoria do agir comunicativo 2: sobre a crítica da razão funcionalista. Tradução de Paulo Astor Soethe; revisão da tradução Flávio Beno Siebeneichler. São Paulo: Editora WMF Martins Fontes, 2012.

HAYDT, R.C. C. Curso de Didática Geral. 8. Ed. São Paulo: Editora Ática, 2006.

HOWATT, A. P. R. A History of English Language Teaching. Oxford: Oxford University Pres, 1984.

HUTCHINSON, T.; WATERS, A. English for specific purposes: a learning-centered approach. Cambridge: Cambridge University Press, 1987. 
HYMES, D. H. On Communicative Competence. In: PRIDE, J.B; HOLMES, J (Eds), Sociolinguistics. Selected Readings. Harmondsworth: Penguin, 1972.

IFB. Instituto Federal de Educação, Ciência e Tecnologia de Brasília - Campus Gama. Plano de curso. Curso de Educação Profissional Técnico de Nível Médio Subsequente em Logística. Brasília, 2010, p. 1-62.

KOCH, I. V. A inter-ação pela linguagem. São Paulo: Contexto, 2013.

O texto e a construção dos sentidos. São Paulo: Contexto, 2014.

KUENZER, A. Z. Ensino Médio: construindo uma proposta para os que vivem do trabalho (Org.) 6. ed. São Paulo: Cortez, 2009.

LARSEN-FREEMAN, D. Defining language and understanding the problem. In:

Teaching language: from Grammar to grammaring. Boston: Thomson Heinle, 2003, p. 110 .

LAVILLE, C.; DIONNE, J. A construção do saber. Porto Alegre. Editora Artes Médicas, 1999.

LEFFA, V.J. Metodologia do ensino de línguas. In BOHN, H. I.; VANDRESEN, P. Tópicos em linguística aplicada: O ensino de línguas estrangeiras. Florianópolis: Ed. da UFSC, 1988. p. 211-236.

LIMA, P. G. Formação de professores: por uma ressignificação do trabalho pedagógico na escola. Editora: EDUFGD, 2010.

MACEDO, N. D. Iniciação à pesquisa bibliográfica: guia do estudante para a fundamentação do trabalho de pesquisa. 2. ed. São Paulo: Loyola, 1994.

MARSH, D. Using Languages to Learn and Learning to Use Languages; An Introduction to CLIL for Parents and Young People. TIE-CLIL, 2000.

;MALJERS, A., A. HARTIALA. Profiling European CLIL Classrooms. UniCOM: University of Jyväskylä, 2001.

MARTINEZ, P. Didática de línguas estrangeiras. São Paulo: Parábola Editorial, 2009.

MARQUES, K. S. B.; GARÍGLIO, M. I. Linguagem para Fins Profissionais: A Conformação de uma Disciplina/Curso no PROGEST/CEFET-MG. The ESPecialist: Pesquisa em Línguas para Fins Específicos. Descrição, Ensino e Aprendizagem, São Paulo, v.29, 2008.

MEHISTO, P., MARSH, D.; FRIGOLS, M.J. Uncovering CLIL. Content and Language Integrated Learning in Bilingual and Multilingual Education. Oxford: Macmillan Education, 2008.

MEIRELES, A. J. Criando uma aquarela: a formação de professores no uso de TICs na aula de línguas estrangeiras. Dissertação (Mestrado em Linguística Aplicada) - Instituto de 
Letras, Departamento de Línguas Estrangeiras e Tradução, Universidade de Brasília, Brasília, 2010 .

MENEGOlLA, M.; SANT’ANNA, I.M. Por que Planejar? Como Planejar? Rio de Janeiro: Vozes, 1991.

MICCOLI, L. S. Ensino e aprendizagem de inglês: experiências, desafios e possibilidades. Campinas: Pontes Editores, 2010.

MORIGI, V. Pesquisando em EJA/Educação profissional em tempos difíceis. In:

PACHECO, Elizier Moreira; MORIGI, Valter (Orgs.). Ensino Técnico, Formação

Profissional e Cidadania: a revolução da educação profissional e tecnológica no Brasil.

Porto Alegre: Tekne, 2012.

MOREIRA, R. S.C. Análise de necessidades para um curso de español no ensino superior tecnológico. Dissertação (Mestrado em Linguística Aplicada e Estudos da Línguagem) Pontifícia Universidade Católica de São Paulo, São Paulo, 2012

MOURA, D.H. A formação docente para uma educação profissional e tecnológica socialmente produtiva. In: INEP. Formação de professores para educação profissional e tecnológica. Coleção Educação Superior em Debate, v. 8. Brasília: Instituto Nacional de Estudos e Pesquisas Educacionais Anísio Teixeira, 2008.

A relação entre a educação profissional e a educação básica na CONAE 2010: possibilidades e limites para a construção do novo Plano Nacional de Educação. Educ. Soc. 2010, v. 31, n. 112, p. 875-894, 2010.

A organização curricular do ensino médio integrado a partir do eixo estruturante: trabalho, ciência, tecnologia e cultura. Revista LABOR, nº 7, v. 1, 2012.

MOURA FILHO, A. C. L. Vamos dar as mãos: a aprendizagem cooperativa de línguas. Contexturas: Ensino crítico de inglês, APLIESP, São Paulo, n. 19, 2012.

MYERS, M. D. Qualitative Research in Information Systems, MIS Quarterly (21:2), June 1997, pp. 241-242. MISQ Discovery, archival version, June 1997. Association for Information Systems (AISWorld) Section on Qualitative Research in Information Systems, updated version, last modified: April 13, 2015.

NUNAN, D. Designing tasks for the communicative classroom. Cambridge: CUP, 1989. 1992.

Research methods in language learning. Cambridge: Cambridge University Press.

PACHECO, E. (Org.). Perspectivas da educação profissional e técnica de nível médio: Proposta de Diretrizes Curriculares. São Paulo: Moderna, 2012.

PAIVA, V. L. M. O; FIGUEIREDO, F.Q. O ensino significativo de gramática em aulas de língua inglesa. 2005. Disponível em: <http://www.veramenezes.com/gramatica.htm>. Acesso em: 05 de jan. de 2014. 
PERRENOUD, P. Construir competências desde a escola. Porto Alegre: Artes Médicas Sul, 1999.

Construindo Competências. Entrevista com Philippe Perrenoud, Universidade

de Genebra. Paola Gentile e Roberta Bencini. In: Nova Escola (Brasil). Setembro de 2000.

PIZZOLATO, C. E. et al. O inglês instrumental em cursos de engenharia e a construção de sentidos. Reverte: Revista de Estudos e Reflexões Tecnológicas da Fatec Indaiatuba, Indaiatuba, v. 6, n. 6, p. 1-15, 2008.

PRABHU, N. S. A dinâmica da aula de língua. Tradução de Almeida Filho, J.C. P; Cardoso, R. C. T. Contexturas: Ensino crítico de inglês, APLIESP, São Paulo, n. 5, 2001. . Second language pedagogy. Oxford: OUP, 1987.

RAJAGOPALAN, K. Por uma lingüística crítica. Linguagem, identidade e a questão ética. São Paulo: Parábola.2003.

RAMOS, R. C. G. Instrumental no Brasil: a desconstrução de mitos e a construção do futuro. In FREIRE, M; VIEIRA-ABRAHÃO, M. H.; BARCELOS, A. M. F. (Orgs). Linguística Aplicada e Contemporaneidade. Campinas, SP: Pontes, 2005.

RIBAS, F.C. Variações motivacionais no ensino e aprendizagem de inglês em contexto de escola pública. Tese (Doutorado em Estudos Linguísticos) - Instituto de Biociências, Letras e Ciências Exatas, Universidade Estadual Paulista "Júlio de Mesquita Filho", São José do Rio Preto, 2008.

RICHARDS, J.C.; RODGERS, T.S. Approaches and methods in language Teaching. New York: Cambridge University Prees, 2. ed. 2001.

.O ensino comunicativo das línguas estrangeiras. In: RENANDYA, W. A.;

RICHARDS, J. C. Portfólio SBS 13. São Paulo: SBS, 2006.

ROBINSON, P. ESP Today: a practtioner's guide. Hemel Hamspsted: Prentice Hall International, 1991.

ROSA, M. V. F. P. C.; ARNOLDO, M.A.G.C.A. A entrevista na pesquisa qualitativa. Belo Horizonte. Autêntica, 2006.

SACRISTÁN, J. G. O currículo: uma reflexão sobre a prática. Porto Alegre: Artmed, 2000.

SANTOMÉ, J.T. Globalização e interdisciplinaridade: o currículo integrado. Tradução de Claúdia Schelling. Porto Alegre: Artes Médicas, 1998.

SANTOS, M.; ALMEIDA FILHO, J. C. P. Análise de Abordagem de Ensino de Línguas no Limite. Revista SIPLE, ano 2, n. 2, 2011.

SAVIANI, D. Sobre a concepção de politecnia. Rio de Janeiro: Ministério da Saúde/FIOCRUZ, 1989. 
A nova lei da educação: trajetória, limites e perspectivas. 8. Ed. Campinas:

Autores Associados, 2003.

SAVIGNON, S. J. Communicative Competence: Theory and Classroom Practice. Reading, Massachussets: Addison-Wesley Publishing Company, 1983.

Communicative Language Teaching: Linguistic theory and classroom practice. En: SAVIGNON, S. J. (Ed.). Interpreting Communicative Language Teaching: contexts and concerns in teacher education. New York: Yale University Press, 2002.

SCARAMUCCI, M.V. R. CELPE-Bras: Porque um exame comunicativo. In: CUNHA, M. J.; SANTOS, P. (Orgs.) Ensino e pesquisa em Português para estrangeiros. Universidade de Brasília: DF, 1996, p. 75-81.

SCHMIDT, M. J. O Ensino Científico das Línguas Modernas. Rio de Janeiro: F Briguier e Cia editoras. 2. ed., 1958.

SERRANI, S. Discurso e Cultura na Aula de Língua - Currículo, Leitura e Escrita. Campinas: Pontes, 2005.

SKEHAN, P. A framework for the implementation of task-based instruction. Applied Linguistic, v. 17, n.1, p. 38-62, 1996.

TARNOPOLSKY, O. Content-Based Internet-Assisted ESP Teaching to Ukrainian University Students Majoring in Psychology. The Reading Matrix. v. 9, n. 2, Setembro, 2009.

TELES, T. V. S. O Papel do Ensino de Língua Inglesa na Formação do Perfeito Negociante (1759-1846). Dissertação (Mestrado em Letras), Universidade Federal de Sergipe, 2012.

TERENZI, D. Inglês para Propósitos Específicos no Ensino Superior Tecnológico: relações entre as percepções dos aprendizes, a proposta da instituição formadora e as demandas de empregadores. Tese (Doutorado em Linguística) - Programa em Linguística da Universidade Federal de São Carlos, São Paulo, 2014.

TESSER, G.J. Ética e Educação: Uma reflexão filosófica a partir da Teoria Crítica de Jürgen Habermas. Tese (Doutorado em Educação) - Faculdade de Educação, Universidade Estadual de Campinas, Campinas, 2001.

THIOLLENT, M. Metodologia da pesquisa-ação. São Paulo: 18. ed., Cortez, 2012.

VASCONCELOS, C. dos S. A construção do conhecimento em sala de aula. São: Libertad, 2000.

VERDUGO, M.D.R. Varieties across Europe. IN: Handbook on CLIL Implementation across Europe. Cyprus Pedagogical Institute Publications. 2011.

VIAN JR, O. Inglês instrumental, inglês para negócios e inglês instrumental para negócios. DELTA: Documentação de Estudos em Linguística Teórica e Aplicada [online], v.15, n.especial, São Paulo, p. 437-457, 1999. 
. A Análise de Necessidades no Ensino de Inglês em Contextos Profissionais/Needs Analysis and English Teaching in Professional Contexts. The ESPecialist: Pesquisa em Línguas para Fins Específicos. Descrição, Ensino e Aprendizagem, São Paulo, v. 29, n. 2, 2008.

. O Ensino de inglês para negócios: diferentes abordagens para diferentes necessidades. The ESPecialist: pesquisa em Línguas para Fins Específicos. Descrição, Ensino e Aprendizagem, São Paulo, v. 35, p. 135-154, 2014.

VIANA, N. Planejamento de cursos de línguas: pressupostos e percurso. In: ALMEIDA FILHO, J.C. P. (Org.). Parâmetros atuais para o ensino de português-língua estrangeira. Campinas, SP: Pontes, 2009.

VIEIRA-ABRAHÃO, M. H. Metodologia na investigação das crenças. In: BARCELOS, A.M. F. B.; _ _ (Org.). Crenças e ensino de línguas: foco no professor, no aluno e na formação de professores. 1. ed. Campinas: Pontes Editores, 2006.

VILLARINO, G. La enseñanza de la gramática dentro del enfoque por tareas. (ed.), El aprendizaje y la enseñanza de la gramática en el aula de ELE. Biblioteca del profesor. Antologías de textos de didáctica del español. Centro Virtual Cervantes, 2010.

VYGOTSKY, L. S. Pensamento e Linguagem. 6. ed. Rio de Janeiro: Martins Fontes, 1998. Formação social da mente. 6. ed. Rio de Janeiro: Martins Fontes, 1998a.

XAVIER, R. P. A aprendizagem em um programa temático de língua estrangeira (inglês) baseado em tarefas em contextos de $5^{\mathrm{a}}$ série do ensino fundamental. Tese (Doutorado) Universidade Estadual de Campinas, Unicamp, 1999.

WAJNRYB, R. Classroom observation tasks: a resource book for language teachers and trainers. Cambridge: Cambridge University Press, 1992.

WALLACE, M. Training Foreign Language Teachers: a reflective approach. Cambridge: CUP, 1991.

WIDDOWSON, H. D. O ensino de línguas para a comunicação. Tradução de José Carlos Paes de Almeida Filho, Campinas, SP: Pontes, 2005.

WILLIS, J. A. A framework for task-based learning. London: Longman, 1996.

WOODWARD, T. Planning lessons and courses: designing sequences of work for the language classroom. Cambridge: Cambridge University Press, 2001.

ZANÓN, J.;ESTAIRE, S. El diseño de unidades didácticas mediante tareas en la clase de español. Monográficos marcoELE, n. 11. Antología de los encuentros internacionales del español como lengua extranjera. Las navas del marqués, 2010. 
APÊNDICE A - TESES E DISSERTAÇÕES SOBRE O ENSINO DE LE NA EPT

\begin{tabular}{|c|c|c|c|}
\hline & TITULO & AUTOR & ANO \\
\hline 1 & $\begin{array}{l}\text { Inglês instrumental em cursos técnicos: as quatro } \\
\text { habilidades. }\end{array}$ & $\begin{array}{l}\text { Sandra Magalhães de } \\
\text { Oliveira }\end{array}$ & 2007 \\
\hline 2 & $\begin{array}{l}\text { O desenvolvimento da habilidade da leitura instrumental } \\
\text { em inglês no ensino técnico agrícola. }\end{array}$ & Sueli Regina de Oliveira & 2007 \\
\hline 4 & $\begin{array}{l}\text { POLI-FOS: uma experiência de ensino-aprendizagem do } \\
\text { francês com fins específicos na Escola Politécnica da } \\
\text { USP. }\end{array}$ & $\begin{array}{c}\text { Guiomar Marins Justino de } \\
\text { Oliveira }\end{array}$ & 2009 \\
\hline 6 & $\begin{array}{l}\text { Crenças sobre o ensino-aprendizagem de inglês (LE) em } \\
\text { contexto de formação profissional: um estudo de caso }\end{array}$ & Eduardo Ferreira dos Santos & 2010 \\
\hline 7 & $\begin{array}{l}\text { Sob Medida: uma proposta de produção de Material } \\
\text { didático de Língua estrangeira (inglês) para aprendizes } \\
\text { de num curso do Ensino Médio profissionalizante de } \\
\text { jovens e adultos, na modalidade PROEJA }\end{array}$ & Liberato Silva Santos & 2010 \\
\hline 8 & $\begin{array}{l}\text { Uma experiência de ensino de francês língua estrangeira } \\
\text { no contexto do profissional de secretariado: francês com } \\
\text { objetivos específicos? }\end{array}$ & Emili Barcellos Martins & 2010 \\
\hline 9 & $\begin{array}{c}\text { Análise de necessidades para um curso de español no } \\
\text { ensino superior tecnológico }\end{array}$ & $\begin{array}{c}\text { Regiane Souza Camargo } \\
\text { Moreira }\end{array}$ & 2012 \\
\hline 10 & $\begin{array}{c}\text { Políticas e planejamento do ensino médio (integrado ao } \\
\text { técnico) e da língua estrangeira (inglês): na mira(gem) } \\
\text { da politecnia e da integração. }\end{array}$ & Daniella de Souza Bezerra & 2012 \\
\hline 11 & $\begin{array}{l}\text { Educação de língua inglesa e novos letramentos: } \\
\text { espaços de mudanças por meio dos ensinos técnicos e } \\
\text { tecnológicos. }\end{array}$ & Daniel de Mello Ferraz & 2012 \\
\hline 12 & $\begin{array}{l}\text { Princípios norteadores para o planejamento de cursos de } \\
\text { línguas para propósitos específicos em curso superior } \\
\text { tecnológico (manutenção de aeronaves): considerando } \\
\text { visões de aprendizes, instituição formadora e } \\
\text { empregadores. }\end{array}$ & Daniela Terenzi & 2014 \\
\hline 13 & $\begin{array}{l}\text { Transposição didática do gênero videoclipe de anúncio } \\
\text { publicitário institucional para o ensino de inglês em um } \\
\text { curso técnico em meio ambiente }\end{array}$ & Francieli de Oliveira & 2012 \\
\hline 14 & $\begin{array}{c}\text { ¿Piedras en el camino? ¡Construyamos un castillo! } \\
\text { Necessidades e interesses de aprendizes de espanhol } \\
\text { de um curso técnico integrado; }\end{array}$ & Paolla Cabral Silva Brasil & 2013 \\
\hline 15 & $\begin{array}{l}\text { Ressignificando o ensino de inglês instrumental em } \\
\text { contexto profissional de nível médio: uma proposta } \\
\text { baseada em sequência didática. }\end{array}$ & Sheilla Andrade de Souza & 2013 \\
\hline
\end{tabular}




\section{APÊNDICE B - TERMO DE CONSENTIMENTO LIVRE E ESCLARECIDO}

Universidade de Brasília - UnB

Instituto de Letras - IL

Departamento de Letras e Tradução - LET

Programa de Pós-Graduação em Linguística Aplicada - PGLA

Prezado (a) Aluno(a),

Eu, Renata Mourão Guimarães, professora de espanhol do Instituto Federal de Brasília e aluna do Programa de Pós-Graduação em Linguística Aplicada da Universidade de Brasília (UnB), realizo, atualmente, uma pesquisa em nível de mestrado. Minha pesquisa propõe identificar os potenciais e as limitações de um planejamento temático-comunicativo no que se refere à aprendizagem da língua espanhola em um curso técnico, tendo como título provisório "PLANEJAMENTO TEMÁTICO-COMUNICATIVO PARA O ENSINO DO ESPANHOL EM CONTEXTO DE EDUCAÇÃO PROFISSIONAL".

Comprometo-me, a título de reciprocidade, apresentar à instituição e aos alunos participantes da pesquisa os resultados obtidos com a investigação, no intuito de contribuir com a prática pedagógica.

Coloco-me à disposição para eventuais esclarecimentos adicionais através do e-mail renata.guimaraes@ifb.edu.br e do telefone xxx.

Gostaria de esclarecer que sua autorização é de suma importância para a realização desse estudo e que essa pesquisa está pautada na observação de princípios éticos que usualmente regem uma investigação dessa natureza. Obrigada!

\section{Renata Mourão Guimarães}

$\mathrm{Eu}$, abaixo assinado(a), li esse documento antes de assiná-lo e declaro que concedo à mestranda Renata Mourão Guimarães, como doação, o direito de uso de gravações de áudio e vídeo, respostas de questionários e de entrevistas e minhas impressões em relação à aprendizagem da língua espanhola e sobre como o meu processo de aprendizagem dessa língua está acontecendo dentro e fora da sala de aula. Tal autorização envolve direitos profissionais de utilização do referido material, no todo ou em parte, em dissertação de mestrado, tese de doutoramento, comunicações em congressos e seminários e publicações de artigos ou periódicos. Sei que meu nome não será divulgado, que não terei despesas e não receberei dinheiro por participar do estudo.

Aluno(a):

Sugestão de pseudônimo a ser utilizado, se necessário:

Local e Data:

Assinatura: 


\section{APÊNDICE C - QUESTIONÁRIOS APLICADOS AOS ALUNOS}

\section{Questionário 1 - Perfil do grupo}

1. Informações Pessoais

\subsection{IDADE}

) Menor que 18 anos

) Entre 18 a 25 anos

) Entre 26 a 30 anos

) Entre 31 a 35 anos

) Entre 36 a 40 anos

) Maior que 40 anos

\subsection{SEXO}

) Masculino

) Feminino

1.3. Você exerce atualmente atividade NÃO ACADÊMICA remunerada?

) $\mathrm{NÃO}$

) Sim, mas é trabalho eventual

) Sim, 20 horas por semana

) Sim, 30 horas por semana

) Sim, 40 horas por semana

) Sim, 44 horas por semana

) Outro:

Se trabalha, responda as questões 3 e 4

2. No meu trabalho, é possível conversar sobre temas diversos com os meus colegas de trabalho:

( ) Não é permitido conversar

) Converso com os colegas, durante o expediente

) Converso durante intervalos e na hora do almoço

3. Normalmente, converso com os meus colegas de trabalho sobre:

4. Qual sua PRINCIPAL fonte de informação de acontecimentos atuais

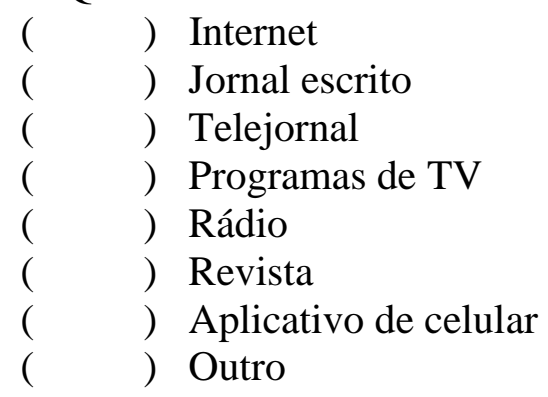

5. Assinale os tipos de informação que mais te interessa

( ) Política 
) Economia/Negócios

) Notícias locais e/ou nacionais

) Notícias internacionais

) Notícias políticas

) Cultura e lazer

) Esportes

) Veículos

) Informática

) Autoajuda

) Religião

) Outro:

6. Com que frequência você busca essas informações?

\begin{tabular}{|c|c|}
\hline ） & Diariamente \\
\hline ) & Semanalmente \\
\hline ) & Ocasionalmente \\
\hline ) & Nunca \\
\hline ) & Outro: \\
\hline
\end{tabular}

7. Assinale o que levou você a escolher um curso técnico. (MARQUE MAIS DE UMA OPÇÃO, SE NECESSÁRIO)

\section{QUESTÃO PESSOAL}

( ) Para minha realização pessoal

) Desenvolvimento pessoal

) Reconhecimento social

) Contribuição na mudança social

) Para ter uma vida social, conhecer e conviver com outras pessoas

) Aquisição de cultura geral

) Por ter afinidade com a área do curso

\section{QUESTÃO PROFISSIONAL}

( ) Qualificação profissional

( ) Maiores oportunidades no mercado de trabalho

( ) Melhorar minha situação atual de trabalho

( ) Melhores perspectivas de ganhos materiais

( ) Conseguir promoção (de cargo) no emprego

( ) Complementação de formação profissional

( ) Por já exercer atividades relacionadas ou semelhantes

( ) Exigência do serviço

( ） Profissão desejada

\section{OUTROS}

( ) Influência de familiares, amigos e/ou terceiros

( ) Por ser gratuito

( ) Pela qualidade do curso oferecido

( ) Pela proximidade com a minha residência

( ) Por ser um curso noturno 
) Por acaso

) Baixa concorrência

8. Percepção geral sobre o curso (Técnico em Logística) que frequenta. MARQUE MAIS DE UMA OPÇÃO, SE NECESSÁRIO

( ) Contribui para que o aluno possa refletir sobre a realidade social brasileira

( ) Busca desenvolver plenamente o potencial de aprendizagem do estudante

( ) Propicia uma formação integral do estudante por meio de uma visão global do contexto social, político, econômico e cultural no qual o estudante está inserido

( ) Proporciona satisfação plena em relação ao nível de aprendizagem e inserção no mercado de trabalho para os estudantes

( ) Está com a grade curricular atualizada em relação ao mercado

( ) Articulação entre o saber teórico e o prático

( ) Articulação entre o Ensino, a Pesquisa e a Extensão

( ) Os conteúdos/programas auxiliaram na formação pessoal e profissional

( ) As disciplinas profissionalizantes contribuem para o desempenho profissional

( ) O curso colabora com o desenvolvimento pessoal, por meio de outras disciplinas gerais.

( ) Outro:

9. Em sua opinião, qual (is) a (s) característica (s) mais importante (s) que um profissional deve possuir atualmente?

) Comunicação eficaz

) Domínio de língua estrangeira

) Conhecimento técnico

) Criatividade e Inovação

) Compromisso social

) Ética profissional

) Capacidade de trabalho em equipe

) Articulação e Argumentação

) Criticidade

) Liderança

) Solucionar conflitos

) Visão do todo

) Aprendizado contínuo

) Outro

\section{Questionário 2 - análise de objetivos (necessidades e interesses)}

1. Você já teve contato com a língua espanhola antes?

) $\mathrm{Sim}$

) Não

2. Caso a resposta da pergunta anterior tenha sido SIM, assinale com um "X" as ocasiões de contato com a língua. Pode marcar mais de uma opção (se for o caso)

( ) No Ensino Fundamental.

( ) No Ensino Médio.

( ) Viagem ao exterior 
) Raramente

) Nunca

5. Em sua opinião, qual a importância do aprendizado de uma língua estrangeira, atualmente.

6. Pensando em você como profissional e cidadão do mundo. Quais deveriam ser os objetivos do ensino de uma língua estrangeira nos dias atuais, em um curso técnico (MARQUE 3 ALTERNATIVAS, AS QUE VOCÊ CONSIDERA DE MAIOR IMPORTÂNCIA)

( ) Compreender e expressar, oralmente e por escrito, opiniões e ideias, entendendo a comunicação como troca de valores culturais

( ) Possibilitar maior entendimento de seu próprio papel como cidadão do país e do mundo em que vive, por meio de discussões de temas diversos na língua estrangeira.

( ) Possibilitar o acesso às informações e ao conhecimento produzido

( ) Compreender e produzir linguagem oral e escrita exigida em seu contexto profissional

( ) Ler e interpretar textos da área

( ) Estudar vocabulário e termos técnicos da área

( ) Conhecimento sistêmico da língua (gramática, normas padrões)

( ) Aprender frases padrões e funções (como cumprimentar, pedir ajuda etc.) das situações comunicativas do ambiente de trabalho

( ) Aprender termos básicos e expressões de uso corrente da língua espanhola

( ) Compreender e redigir textos técnicos e documentos de natureza variada

7. O que você considera ser necessário saber em língua estrangeira para lidar eficazmente em determinada situações no âmbito pessoal e profissional (pensando nas necessidades de sua área)?

8. O que você gostaria de aprender (seus interesses) em espanhol durante este curso?

9. Marque as atividades que você gostaria que fossem trabalhadas durante as aulas. Pode selecionar mais de um se for o caso.

( ) Leitura e interpretação de textos variados (textos de revistas, jornais, livros etc.)

( ) Leitura e redação de textos técnicos (e-mails, relatórios, contratos, catálogos, instruções, documentos legais etc.)

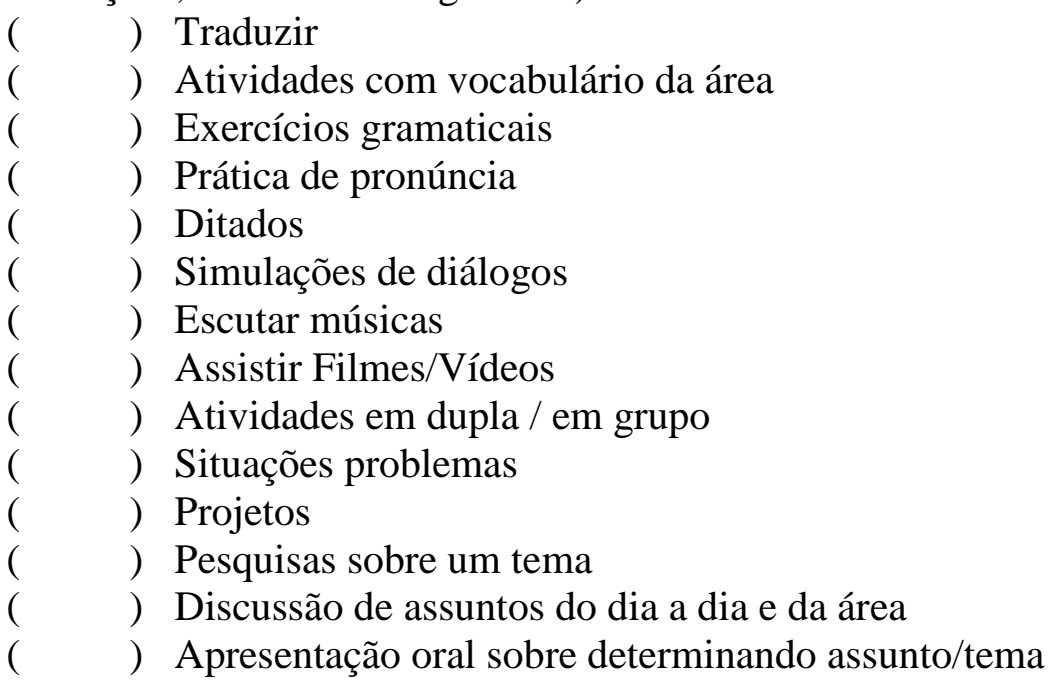


( ) Troca de ideias e opiniões

( ) Conversas livres em espanhol

( ) Compreensão oral (completar informações, circular/escrever palavras e tomar notas do que ouvir)

( ) Outras. Quais?

10. Quais temas da área de Logística você gostaria que fossem trabalhados em sala?

11. Quais temas gerais você gostaria que fossem trabalhados em sala?

12. Avalie o seu interesse (motivação) para aprender espanhol nesse curso. Classifique-o de 1 a 5 , sendo 1 (sem interesse) e 5 (altamente motivado)
1
2
3
4
5 


\section{APÊNDICE D - INSTITUTOS FEDERAIS QUE OFERECEM O CURSO DE LOGÍSTICA (TÉCNICO E TECNOLÓGICO)}

1. IFAC - Instituto Federal do Acre; oferece tecnólogo em Logística no Campus Rio Branco;

2. IFAM - Instituto Federal do Amazonas; oferece técnico em Logística no Campus ManausDistrito Industrial;

3. IFBaiano - Instituto Federal Baiano; oferece técnico em Logística à distância para os polos presenciais de Alagoinhas, Teixeira de Freitas, Uruçuca e Valença;

4. IFES - Instituto Federal do Espirito Santo; oferece técnico em Logística no Campus Cariacica;

5. IFG - Instituto Federal de Goiás; oferece tecnólogo em Logística no Campus Anápolis;

6. IFMA - Instituto Federal do Maranhão; oferece técnico em Logística no Campus Santa Inês;

7. IFMG - Instituto Federal de Minas Gerais; oferece técnico em Logística nos Campi Ribeirão das Neves e Sabará;

8. IFSudesteMG - Instituto Federal do Sudeste de Minas Gerais; oferece tecnólogo em Logística na modalidade presencial no Campus São João Del Rei e técnico em Logística à distância para os polos presenciais de Juiz de Fora, Manhumirim, Rio Pomba e Visconde do Rio Branco;

9. IFTM - Instituto Federal do Triângulo Mineiro; oferece técnico em Logística à distância para os polos presenciais de Carmo do Paranaíba, Presidente Olegário, Dom Bosco, Buritis, Brasilândia de Minas, Urucuia, Unaí, Santa Fé de Minas, Lagoa Grande, Cristalina(GO) e tecnólogo em Logística no Campus Uberlândia;

10. IFSULMG - Instituto Federal do Sul de Minas Gerais; oferece técnico em Logística à distância para o polo presencial de Jacutinga,

11. IFMS - Instituto Federal do Mato Grosso do Sul; oferece técnico em Logística a distância para os polos presenciais de Campo Grande, Corumbá, Dois Irmãos do Buriti, Eldorado, Jardim, Ladário, Paranaíba, Ponta Porã, Terenos e Três Lagoas em parceria com o IFPR;

12. IFPR - Instituto Federal do Paraná; oferece técnico em Logística a distância para polos presenciais em diversas localidades nos estados do Paraná, Mato Grosso do Sul, Rondônia, Bahia, Minas Gerais e Piauí;

13. IFRS - Instituto Federal do Rio Grande do Sul; oferece técnico em Logística no Campus Erechim e tecnólogo em Logística nos Campi Bento Gonçalves e Canoas; 
14. IFRO - Instituto Federal de Rondônia; oferece técnico em Logística à distância nos polos presenciais de Ariquemes, Cacoal, Colorado do Oeste, Guarajá-Mirim, Ji-Paraná, Porto Velho Zona Norte e Vilhena;

15. IFSP - Instituto Federal de São Paulo; oferece técnico em Logística no Campus Registro; 16. IFS - Instituto Federal de Sergipe; oferece tecnólogo em Logística no Campus Itabaiana; 17. IFTO - Instituto Federal de Tocantins; oferece técnico e tecnólogo em Logística no Campus Porto Nacional;

18. IFCE - Instituto Federal do Ceará; oferece técnico em Logística no Campus Quixadá; 19. IFB - Instituto Federal de Brasília; oferece técnico em Logística no Campus Gama; 20. IFNMG - Instituto Federal do Norte de Minas Gerais; oferece técnico em Logística a Distância nos polos presenciais de Arinos, Januária, Montes Claros e Pirapora;

21. IFGoiano - Instituto Federal Goiano; oferece técnico em Logística a Distância nos polos presenciais de Catalão, Corumbaíba, Crixás, Goianápolis, Goiânia, Hidrolândia, Ipameri, Itapaci, Itapuranga, Minaçu, Mineiros, Montividiu do Norte, Orizona, Piracanjuba, Professor Jamil, Rialma, Rio Verde, Rubiataba, São Simão, Silvânia e Vianópolis;

22. IFRN - Instituto Federal do Rio Grande do Norte; oferece técnico em Logística no Campus São Gonçalo do Amarante.

Entre eles, 5 oferecem língua estrangeira (inglês) e 1 oferece língua espanhola (IFB). A saber:

1. IFSudesteMG - Instituto Federal do Sudeste de Minas Gerais - Técnico em Logística (EaD)Inglês instrumental;

2. IFTM- Instituto Federal do Triângulo Mineiro - Técnico em Logística (EaD) - Inglês instrumental;

3. IFRS - Instituto Federal do Rio Grande do Sul - Tecnólogo em Logística - Inglês instrumental;

4. IFTO - Instituto Federal de Tocantins - Técnico e Tecnólogo em Logística - Inglês técnico;

\section{IFB - Instituto Federal de Brasília - Técnico em Logística - Espanhol para negócios;}

6. IFCE - Instituto Federal do Ceará - Técnico em Logística - Inglês instrumental. 


\section{APÊNDICE E - QUESTIONÁRIO - ENVIADO AS EMPRESAS DA ÁREA DE LOGÍSTICA}

\section{I- Identificação}

1. Empresa onde trabalha:

2. Ramo de atividade:

3. Cargo na empresa:

II- Questões

1. Descreva as principais tarefas que você desempenha no dia-a-dia em seu trabalho.

2. A língua estrangeira é usual em seu trabalho?

$$
\text { ) Sim }
$$

3. Se a resposta foi afirmativa para a questão anterior. Especifique qual língua estrangeira é utilizada em seu trabalho

$\begin{array}{lll}( & \text { (n) } & \text { Inglês } \\ ( & \text { ( ) } & \text { Espanhol } \\ ( & \text { ) } & \text { Outras. Quais? }\end{array}$

4. Em quais os cargos dentro de sua empresa os profissionais de Logística utilizam a língua estrangeira?

5. Quais as habilidades em língua estrangeira são mais utilizadas em seu trabalho?

$\begin{array}{lll}( & \text { ) } & \text { Ler } \\ ( & ) & \text { Escrever } \\ ( & \text { ) } & \text { Ouvir } \\ ( & \text { ) } & \text { Falar }\end{array}$

6. Com que frequência a língua estrangeira é utilizada em seu trabalho?

$$
\begin{array}{lll}
(\quad) & \text { Sempre } \\
(\quad \quad) & \text { Frequentemente } \\
(\quad \quad) & \text { Às vezes }
\end{array}
$$

7. Com quem você utiliza a língua estrangeira no seu trabalho?

$\begin{array}{lll}( & \text { ) } & \text { Clientes } \\ ( & \text { ) } & \text { Funcionários } \\ ( & \text { ( ) } & \text { Fornecedores } \\ ( & \text { ) } & \text { Outros. Quais? }\end{array}$

8. Quais são as formas de contato com estrangeiros? Se necessário, assinale mais de uma alternativa.

$\begin{array}{lll}( & \quad & \text { Face a face } \\ ( & \text { ) } & \text { Telefone } \\ ( & \text { ) } & \text { Videoconferência } \\ ( & \quad & \text { Skype ou similar. }\end{array}$


( ) Outros. Quais?

9. Assinale com um "X" as atividades em que você utiliza a língua estrangeira. Assinale mais de uma alternativa, se necessário.

LER

\begin{tabular}{|c|c|c|}
\hline ( & ) & Leitura de $e$-mail \\
\hline ( & ) & Leitura de sites em língua estrangeira \\
\hline ( & ) & Leitura de relatórios \\
\hline ( & ) & Leitura correspondência impressa \\
\hline & ) & Leitura de documentos (faturas, recibos, nota fiscal etc) \\
\hline & ) & Outras. Quais? \\
\hline
\end{tabular}

\section{ESCREVER}

( ) Redação de $e$-mails

( ) Redação de relatórios

( ) Redação de correspondência impressa

( ) Outras. Quais?

\section{FALAR}

( ) Viagens de trabalho

( ) Atendimento telefônico

( ) Reuniões com empresas estrangeiras

( ) Atender clientes/fornecedores

( ) Realizar pedidos de mercadorias

( ) Outras. Quais?

\section{ESCUTAR}

$\begin{array}{lll}( & \text { ( ) } & \text { Conversa telefônica } \\ ( & \text { ) } & \text { Conversa face a face } \\ ( & \text { ) } & \text { Outras. Quais? }\end{array}$

10. Em relação à área de Logística e à língua estrangeira, o que você considera importante aprender para se sentir apto no trabalho? 


\section{APÊNDICE F - QUESTIONÁRIO 3 - QUESTIONÁRIO DE AUTOAVALIAÇÃO FINAL PARA OS ALUNOS}

\section{Percepção dos alunos (vivências pedagógicas no âmbito do componente curricular LE)}

1. Faça uma autoavaliação em termos de aprendizagem nesse curso. Atribua uma classificação para o seu desempenho em LE (muito bom, bom, aceitável, ruim, muito, ruim) e justifique sua escolha buscando identificar os fatores que contribuíram para isso.

2. Fale sobre seus maiores "ganhos" em termos de formação cidadã? O que considera que aprendeu ou adquiriu durante os nossos encontros e atividades?

3. Em sua opinião, quais as atividades feitas em sala foram mais significativas para a sua aprendizagem?

4. Como foi sua participação durante as aulas?

5. Você termina o curso

( ) Mais motivado para dar continuidade a aprendizagem da língua espanhola

( ) Achando que o que aprendeu foi suficiente.

( ) Desmotivado porque não sentiu progresso. (Se assinalou esta alternativa, procure identificar a causa).

( ) Com suas expectativas correspondidas.

( ) Com suas expectativas não correspondidas. (Justifique)

Agradeço, imensamente, sua valiosa colaboração e tempo prestado no preenchimento deste questionário. Fique à vontade para dar sugestões, críticas, depoimentos e comentários. Cordialmente, Renata Guimarães. 


\section{APÊNDICE G - ANÁLISE DO CATÁLOGO DE CURSOS TÉCNICOS}

\section{TÉCNICO EM ADMINISTRAÇÃO - 800 h}

POSSIBILIDADES DE TEMAS A SEREM PERFIL

ABORDADOS

\begin{tabular}{ll}
$\begin{array}{l}\text { Organização empresarial } \\
\text { Matemática financeira }\end{array}$ & $\begin{array}{l}\text { Executa as funções de apoio } \\
\text { administrativo: protocolo e arquivo, }\end{array}$ \\
$\begin{array}{l}\text { Legislação trabalhista, tributária empresarial } \\
\text { Arquivamento }\end{array}$ & $\begin{array}{l}\text { confecção e expedição de documentos } \\
\text { administrativos e controle de estoques. } \\
\text { Rotinas trabalhistas, financeiras e contábeis } \\
\text { Métodos e técnicas administrativas }\end{array}$ \\
$\begin{array}{l}\text { Opera sistemas de informações gerenciais } \\
\text { de pessoal e material. Utiliza ferramentas } \\
\text { da informática básica, como suporte às } \\
\text { operações organizacionais. }\end{array}$ \\
\hline
\end{tabular}

2. TÉCNICO EM COMÉRCIO - 800 horas

\begin{tabular}{|c|c|}
\hline $\begin{array}{l}\text { POSSIBILIDADES DE TEMAS A SEREM } \\
\text { ABORDADOS }\end{array}$ & PERFIL \\
\hline Comércio & Aplica métodos de comercialização de \\
\hline Aprovisionamento, controle e armazenagem & bens e serviços, visando à \\
\hline Documentação comercial & competitividade no mercado \\
\hline Equipamentos comerciais & atendendo às diretrizes organizacionais. \\
\hline Matemática comercial e financeira & Comunica previsões e demandas aos \\
\hline Legislação trabalhista, tributária & fornecedores. Efetua controle \\
\hline empresarial & quantitativo e qualitativo de produtos e \\
\hline Rotinas trabalhistas, financeiras e contábeis & procede a sua armazenagem no \\
\hline Técnicas administrativas & estabelecimento comercial. \\
\hline Política cambial & $\begin{array}{l}\text { Operacionaliza planos de marketing e } \\
\text { comunicação, Logística, recursos } \\
\text { humanos e comercialização. }\end{array}$ \\
\hline
\end{tabular}

\section{TÉCNICO EM COMÉRCIO EXTERIOR - 800 horas}

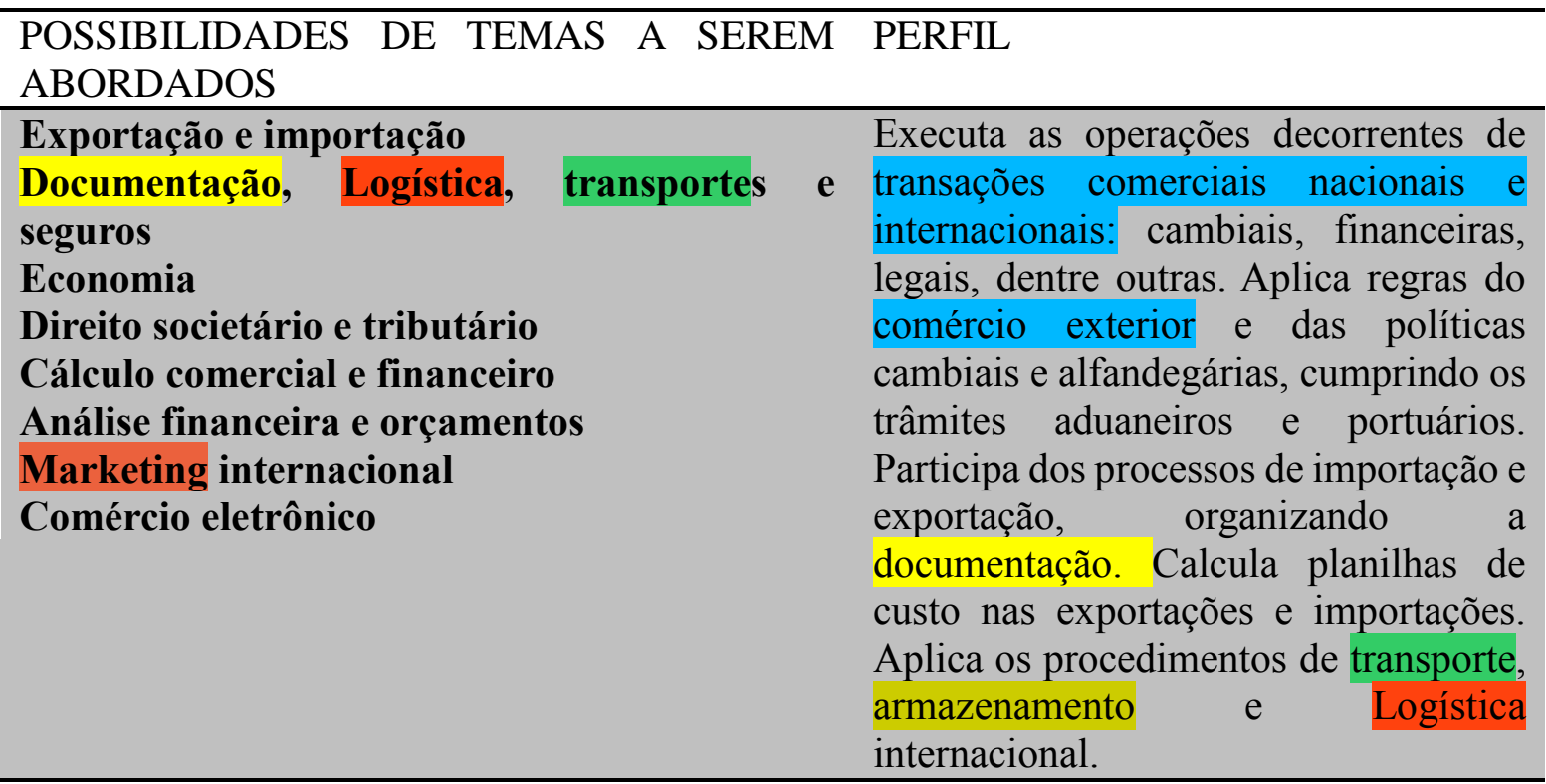


4. TÉCNICO EM CONTABILIDADE - 800 horas

\begin{tabular}{|c|c|}
\hline $\begin{array}{l}\text { POSSIBILIDADES DE TEMAS A } \text { SEREM } \\
\text { ABORDADOS }\end{array}$ & PERFIL \\
\hline $\begin{array}{l}\text { Organização empresararial } \\
\text { Análise financeira e orçamentos } \\
\text { Direito público e privado } \\
\text { Legislação trabalhista, tributária e empresarial } \\
\text { Normas brasileiras de contabilidade } \\
\text { Fiscalização } \\
\text { Contabilidade } \\
\text { Custos e patrimônio } \\
\text { Matemática financeira }\end{array}$ & $\begin{array}{l}\text { Efetua anotações das transações } \\
\text { financeiras da organização e examina } \\
\text { documentos fiscais e parafiscais. } \\
\text { Analisa a documentação contábil e } \\
\text { elabora planos de determinação das } \\
\text { taxas de depreciação e exaustão dos } \\
\text { bens materiais, de amortização dos } \\
\text { valores imateriais. Organiza, controla } \\
\text { e arquiva os documentos relativos à } \\
\text { atividade contábil e controla as } \\
\text { movimentações. Registra as } \\
\text { operações contábeis da empresa, } \\
\text { ordenando os movimentos pelo débito } \\
\text { e crédito. Prepara a documentação, } \\
\text { apura haveres, direitos e obrigações } \\
\text { legais. }\end{array}$ \\
\hline
\end{tabular}

\section{TÉCNICO EM COOPERATIVISMO - 800 horas}

\begin{tabular}{|c|c|}
\hline $\begin{array}{l}\text { POSSIBILIDADES DE } \\
\text { ABORDADOS }\end{array}$ & PERFIL \\
\hline $\begin{array}{l}\text { Economia } \\
\text { Legislação cível e trabalhista } \\
\text { Contabilidade } \\
\text { Operações de cooperativas } \\
\text { Sistemas de informação } \\
\text { Marketing } \\
\text { Finanças } \\
\text { Gestão e organização do trabalho } \\
\text { Técnicas de negociação }\end{array}$ & $\begin{array}{l}\text { Atua na formação e no } \\
\text { desenvolvimento de cooperativas. } \\
\text { Planeja e executa os processos } \\
\text { cooperativos em suas diversas } \\
\text { modalidades. Atua na gestão de } \\
\text { contratos, assegurando o } \\
\text { cumprimento da legislação } \\
\text { trabalhista. Presta assistência e } \\
\text { serviços em cooperativas. Orienta a } \\
\text { elaboração e desenvolvimento de } \\
\text { projetos em comunidades rurais e } \\
\text { urbanas. Executa pesquisas em } \\
\text { cooperativismo. }\end{array}$ \\
\hline
\end{tabular}

6. TÉCNICO EM FINANÇAS - 800 horas

POSSIBILIDADES DE TEMAS A SEREM PERFIL

ABORDADOS

\begin{tabular}{|c|c|}
\hline $\begin{array}{l}\text { ática financeira } \\
\text { ilidade } \\
\text { financeiro } \\
\text { de giro, caixa, estoques, contas } \\
\text { a receber } \\
\text { tos }\end{array}$ & $\begin{array}{l}\text { Efetua atividades nas negociações } \\
\text { bancárias e nos setores de tesouraria, } \\
\text { contabilidade, análise de crédito, } \\
\text { orçamento empresarial, custos e } \\
\text { formação de preços. Identifica os } \\
\text { diversos indicadores econômicos e } \\
\text { financeiros e sua importância para } \\
\text { análise financeira. Lê e interpreta } \\
\text { demonstrativos financeiros. Realiza }\end{array}$ \\
\hline
\end{tabular}




\begin{tabular}{ll}
\hline Orçamento e planejamento & fluxo de caixa, lançamentos financeiros, \\
& ordens de pagamento, contas a pagar e \\
& receber e cobranças. Coleta e organiza \\
& informações para elaboração do \\
& orçamento empresarial e análise \\
patrimonial.
\end{tabular}

7. TÉCNICO EM LOGÍSTICA - 800 horas.

POSSIBILIDADES DE TEMAS A SEREM PERFIL ABORDADOS

\begin{tabular}{ll}
\hline Logística & $\begin{array}{l}\text { Aplica os principais procedimentos de } \\
\text { Gestão de pessoas } \\
\text { Gerenciamento e economia de sistemas } \\
\text { logísticos }\end{array}$ \\
$\begin{array}{l}\text { transporte, armazenamento e Logística. } \\
\text { Eegislação e tributação em Logística } \\
\text { Estocagem }\end{array}$ & $\begin{array}{l}\text { manutenção de menda programa de } \\
\text { equipamentos, compras, recebimento, } \\
\text { Transportes }\end{array}$ \\
Custos & $\begin{array}{l}\text { expedição e distribuição de materiais e } \\
\text { produtos. Colabora na gestão de } \\
\text { estoques. Presta atendimento aos } \\
\text { clientes. Implementa os procedimentos } \\
\text { de qualidade, segurança e higiene do } \\
\text { trabalho no sistema logístico. }\end{array}$ \\
\hline
\end{tabular}

8. TÉCNICO EM MARKETING - 800 horas

\begin{tabular}{ll}
\hline POSSIBILIDADES DE TEMAS A SEREM & PERFIL \\
ABORDADOS & \\
\hline Organização empresarial & Colabora na elaboração do plano de \\
Logística & marketing da empresa e no no \\
Planejamento de marketing & planejamento e implementação de ações \\
Legislação & de marketing pontuais. Executa tarefas \\
Comportamento do consumidor & de análise das vendas, preços e \\
Análise de mercado & produtos. Operacionaliza as políticas de \\
Estatística & comunicação da empresa: fidelização de \\
Merchandising & clientes, relação com fornecedores ou \\
Publicidade & outras entidades. Executa o controle, \\
Marketing mix e de clientes & estatísticas e operações de \\
Comunicação & telemarketing. Operacionaliza políticas \\
Telemarketing & de apresentação dos produtos no ponto \\
& de venda. Participa na elaboração e \\
& realização de estudos de mercado.
\end{tabular}


9. TÉCNICO EM QUALIDADE - 800 horas

\begin{tabular}{|c|c|}
\hline $\begin{array}{l}\text { POSSIBILIDADES DE TEMAS A SEREM } \\
\text { ABORDADOS }\end{array}$ & PERFIL \\
\hline $\begin{array}{l}\text { Qualidade } \\
\text { Normalização e legislação da qualidade } \\
\text { Estatística } \\
\text { Planejamento e auditoria } \\
\text { Comunicação } \\
\text { Produtividade } \\
\text { Contabilidade } \\
\text { Segurança e saúde do trabalho } \\
\text { Processos administrativos e industriais }\end{array}$ & $\begin{array}{l}\text { Colabora na elaboração de manuais, } \\
\text { procedimentos, diagnósticos e } \\
\text { relatórios dos processos de qualidade } \\
\text { das empresas. Registra o controle da } \\
\text { qualidade, em formulários específicos e } \\
\text { de acordo com as normas e padrões } \\
\text { preestabelecidos. Atua na elaboração e } \\
\text { execução da auditoria interna da } \\
\text { qualidade e acompanha a auditoria } \\
\text { externa. Divulga os procedimentos de } \\
\text { qualidade e propõe ações de informação } \\
\text { e formação específica. Identifica } \\
\text { inconformidades em produtos e } \\
\text { processos, suas possíveis causas e ações } \\
\text { corretivas e preventivas. }\end{array}$ \\
\hline
\end{tabular}

10. TÉCNICO EM RECURSOS HUMANOS - 800 horas

POSSIBILIDADES DE TEMAS A SEREM PERFIL
ABORDADOS

Cultura, ética e valores organizacionais

Executa rotinas de departamento de Legislação trabalhista e previdenciária pessoal (pesquisa, integração, Avaliação de desempenho

Plano de carreira

Recrutamento e seleção

Gestão e organização do trabalho

Rotinas de pessoal

Motivação e liderança

Saúde ocupacional treinamento, folha de pagamento, tributos e benefícios). Descreve e classifica postos de trabalho, aplica questionários e processa informações acerca dos trabalhadores. Presta serviços de comunicação, liderança, motivação, formação de equipes e desenvolvimento pessoal. Atua em processos de orientação sobre a importância da segurança no trabalho e da saúde ocupacional.

11. TÉCNICO EM SECRETARIADO - 800 horas

POSSIBILIDADES DE TEMASA SEREM PERFIL

ABORDADOS

\begin{tabular}{ll}
\hline Técnicas e rotinas secretariais & $\begin{array}{l}\text { Organiza a rotina diária e mensal da } \\
\text { chefia ou direção, para o cumprimento } \\
\text { Conhecimentos de língua portuguesa } \\
\text { estrangeira }\end{array}$ \\
$\begin{array}{l}\text { Legislação e organização empresarial } \\
\text { Economia }\end{array}$ & $\begin{array}{l}\text { os canais de comunicação da chefia ou } \\
\text { direção com interlocutores, internos e }\end{array}$ \\
Psicologia comportamental & externos, em língua nacional e \\
Gestão e organização do trabalho & estrangeira. Organiza tarefas relacionadas \\
Marketing pessoal & como expediente geral do secretariado da \\
& chefia ou direção. Controla e arquiva \\
documentos. Preenche e confere
\end{tabular}


documentação de apoio à gestão organizacional. Utiliza aplicativos e a internet na elaboração, organização e pesquisa de informação.

12. TÉCNICO EM SEGUROS - 800 horas POSSIBILIDADES DE TEMASA SEREM PERFIL ABORDADOS

Seguridade
Legislação brasileira de seguros
Noções do Código Civil Brasileiro
Contabilidade de seguros
Liquidação de sinistros
Comercialização
Relações interpessoais
Contratos e modalidades de seguros (vida e
não vida)

Controla contas correntes relativas a prêmios e sinistros e organiza fatos contábeis, com base nas normas e limites técnicos operacionais. Subscreve e inspeciona riscos. Avalia acessos e riscos de sinistros e concede participação de riscos ao mercado. Operacionaliza cálculos de prêmios e outros procedimentos.

\section{TÉCNICO EM SERVIÇOS DE CONDOMÍNIO - 800 horas}

POSSIBILIDADES DE TEMAS A SEREM PERFIL

ABORDADOS

\begin{tabular}{|c|c|}
\hline $\begin{array}{l}\text { Condomínio } \\
\text { Conservação e manutenção predial } \\
\text { Administração financeira, de pessoal } \\
\text { materiais } \\
\text { Legislação trabalhista, tributária } \\
\text { previdenciária } \\
\text { Segurança patrimonial } \\
\text { Gestão ambiental }\end{array}$ & $\begin{array}{l}\text { Executa as ações decorrentes das } \\
\text { decisões das assembleias condominiais, } \\
\text { envolvendo procedimentos } \\
\text { organizacionais, de recursos humanos, } \\
\text { materiais, financeiros, conservação e } \\
\text { manutenção predial. Conduz reuniões e } \\
\text { elabora atas e relatórios de prestação de } \\
\text { contas. Promove a integração dos vários }\end{array}$ \\
\hline
\end{tabular}

\section{TÉCNICO EM SERVIÇOS JURÍDICOS - 800 HORAS}

\begin{tabular}{|c|c|}
\hline $\begin{array}{l}\text { POSSIBILIDADES DE TEMAS A SEREM } \\
\text { ABORDADOS }\end{array}$ & $\mathrm{PE}$ \\
\hline $\begin{array}{l}\text { Introdução ao Direito } \\
\text { Teoria Geral do Processo } \\
\text { Técnicas de redação } \\
\text { Qualidade no atendimento ao público } \\
\text { Noções de Direito Constitucional, Civil, } \\
\text { Administrativo, Penal e Empresarial } \\
\text { Processos e procedimentos administrativos } \\
\text { Ciclo tributário } \\
\text { Fundamentos da legislação trabalhista }\end{array}$ & $\begin{array}{l}\text { Executa serviços de suporte e apoio } \\
\text { técnico-administrativo a escritórios de } \\
\text { advocacia, de auditoria jurídica, } \\
\text { recursos humanos e departamentos } \\
\text { administrativos, bem como cumpre as } \\
\text { determinações legais atribuídas a } \\
\text { cartórios judiciais e extrajudiciais, } \\
\text { executando procedimentos e registros } \\
\text { cabíveis. E responsável pelo } \\
\text { gerenciamento e pelo arquivo de } \\
\text { processos e de documentos técnicos. } \\
\text { Presta atendimento ao público. }\end{array}$ \\
\hline
\end{tabular}


15. TÉCNICO EM SERVIÇOS PÚBLICOS - 800 horas

\begin{tabular}{lll}
\hline POSSIBILIDADES DE TEMAS A & SEREM & PERFIL \\
ABORDADOS & Executa as operações decorrentes de \\
\hline Administração pública & programas e projetos de políticas \\
Políticas sociais e econômicas & públicas. Executa as funções de apoio \\
Contabilidade & administrativo. Auxilia no controle \\
Orçamento e licitação & dos procedimentos organizacionais. \\
Finanças & Auxilia na organização dos recursos \\
Atendimento ao público & humanos e materiais. Utiliza \\
Liderança e qualidade & ferramentas de informática básica \\
& como suporte às operações. \\
\hline
\end{tabular}

16. TÉCNICO EM TRANSAÇÕES IMOBILIÁRIAS - 800 horas

\begin{tabular}{ll}
\hline $\begin{array}{l}\text { POSSIBILIDADES DE TEMAS A SEREM } \\
\text { ABORDADOS }\end{array}$ & PERFIL \\
\hline Economia e mercado & Assessora ações de compra, venda e \\
Operações imobiliárias & locação de imóveis. Registra as \\
Marketing & avaliações de transações imobiliárias. \\
Matemática financeira & Orienta registro e transferência de \\
Código de Defesa do Consumidor & imóveis junto aos órgãos competentes. \\
Legislação imobiliária & Inscreve imóveis no cadastro da \\
Técnicas de negociação e vendas & imobiliária, apresenta os imóveis aos \\
clientes potenciais e orienta & investimentos natividade. Identifica e \\
aplica os parâmetros de uso e ocupação \\
para lotes urbanos. Lê e interpreta \\
projetos e mapas.
\end{tabular}

17. TÉCNICO EM VENDAS - 800 horas

\begin{tabular}{ll}
\hline POSSIBILIDADES DE TEMAS A SEREM & PERFIL \\
ABORDADOS & \\
\hline Estratégias de compra e venda & Estuda os produtos e serviços da \\
Contabilidade & empresa, caracteriza o tipo de clientes \\
Comunicação & e recolhe informações sobre a \\
Gestão financeira & concorrência e o mercado em geral. \\
Produtos e serviços & Prepara ações de venda. Promove e \\
Pesquisa de mercado & efetua a venda de produtos e serviços \\
Marketing & junto aos clientes, bem como a \\
Merchandising & organização do ambiente de venda. \\
Legislação & Promove serviço de apoio ao cliente, \\
Leiaute de loja e vitrinismo & fidelização e atendimento pós-venda. \\
Empreendedorismo & Organiza e gerencia os arquivos dos \\
& clientes. Colabora na captação de \\
novos clientes.
\end{tabular}




\section{APÊNDICE H - ANÁLISE DA ENTREVISTA APLICADA AOS PROFISSIONAIS DA ÁREA DE LOGÍSTICA}

Codificamos e categorizamos, em forma de legenda em cores, partes das entrevistas, aplicada aos profissionais da área de Logística, guiadas pelas perguntas que seguem:

a) Utiliza-se alguma LE na empresa?

b) Quais as habilidades reconhecidas na descrição com maior ou menor proporção?

c) É possível identificar a frequência com que utilizam a LE? Com quem, normalmente, utilizam a LE? De que forma a LE é utilizada? Pessoalmente, e-mail, face a face... Em quais atividades do cotidiano profissional ela é mais presente?

d) É possível identificar a importância que as empresas atribuem à $\square$ endizagem da LE?

\section{EMPRESA 1 (E1) \\ Ramo: Atacado de frutas em geral \\ Cargo do entrevistado: Gerente Comercial (PE1)}

1. Compra e venda de hortifruti, programação de cargas, organização de entregas, programação de classificação de produtos, acompanhamento de resultados, reuniões diversas. 2. Como trabalhamos somente com comercialização interna, até o momento não tivemos necessidade da utilização de outros idiomas. Acho que ler pra gente pode ser o mais importante, lemos às vezes, mas raramente para ler algum artigo em algum site, internet. No caso de começar a exportar os produtos, teríamos necessidade principalmente do inglês e espanhol.

\section{EMPRESA 2 (E2) \\ Ramo: Logística e armazenagem \\ Cargo do entrevistado: Supervisor operacional (PE2)}

1. Nossa empresa trabalha com serviços de importação e exportação(...) na chegada do caminhão, carreta, trem ou via área (...) se faz necessário à conferência dos seguintes itens: placa do veículo, lacre de segurança, nome do motorista, empresa que está transportando e o mais importante verificar se está no prazo de chegada (...) neste processo é necessário conhecimento em falar outros idiomas, porque às vezes recebemos mercadorias de fora, vem motorista estrangeiro.

2. Sim. Inglês e espanhol. (...) Ler, escrever, ouvir, falar. Usamos a língua, por exemplo, na portaria onde se faz a triagem das documentações; se usa no armazém na hora de realizar a conferência dos produtos; se usa no controle interno de emissão de notas ou ordem de saida. Então muitas vezes usamos inglês e espanhol com os motoristas e geralmente recepcionamos cliente que querem conferir suas mercadorias (...). Acho que é de extrema importância a leitura, porque chegam muitos motoristas de fora e toda a documentação das mercadorias é em língua estrangeira e também seus documentos pessoais. 


\section{EMPRESA 3 (E3)}

Ramo: Locação de móveis

Cargo do entrevistado: Líder de Logística (PE3)

1. Armazenagem de itens, manutenção e embalagem, leitura para constar em estoque, notas fiscais de entrada e saída. A empresa é estrangeira e trocamos informações com embaixadas. Temos que falar de preços, prazos, condições da locação.

2. Usamos mais o inglês, na maioria das vezes, mas é mais o líder de Logística sempre está em contato com o cliente (embaixadas). Têm que conseguir ler e falar pelo menos o básico.

\section{EMPRESA 4 (E4) \\ Ramo: Fábrica de bebidas \\ Cargo do entrevistado: Encarregado de Logística (PE4)}

1. Usamos a LE para ler embalagens, alguma descrição na internet. Como é uma empresa nacional não temos contato direto com nenhum estrangeiro. Mas muita da matéria prima que recebemos vem de fora, mas temos fornecedores intermediários que negociam com esses fabricantes de matéria prima estrangeira. Por isso o nosso contato com o idioma não é tão de forma direta. Os cargos de chefiam algumas vezes participam de reuniões

2. Acho que a língua estrangeira é importante, mas não sei dizer ao certo que cargo pode ser mais usada aqui, mas acho que mais para as chefias (...) sabemos que ela é importante e não só para buscar as especificações de produtos como normalmente fazemos, mas para comunicar mesmo, conversar, pedir, negociar. Acredito que quando se tem o inglês fluente as pessoas já te veem diferente.

\section{EMPRESA 5 (E5)}

Ramo: Atacadista de Alimentação

Cargo do entrevistado: Encarregado de Logística (PE5)

1. Organizo as cargas e descargas de produtos, alocação das mercadorias, entrada e saída de materiais, tudo o que for relacionado ao recebimento dos caminhões nas docas.

2. Não usamos a língua estrangeira, nem espanhol, nem inglês. Mas acho importante saber linguas, abre portas para o mercado de trabalho.

\section{EMPRESA 6 (E6)}

Ramo: Construção Civil

Cargo do entrevistado: Conferente (PE6)

1. Faço levantamento de material, recebimento de material e transporte até a obra.

2. Usamos o espanhol às vezes com engenheiros e arquitetos, lemos e-mails, sites, documentos.

Seria bom ser fluente na língua, facilitaria alguns trabalhos.

\section{EMPRESA 7 (E7)}

Ramo: Distribuição e vendas de materiais para construção

Cargo do entrevistado: Assistente de Logística (PE7)

1. Acompanho a entrada e saída de caminhões, acompanho carga e descarga, defino rotas de entregas das mercadorias e controle de notas. 
2. Utilizamos, às vezes, o inglês e espanhol na leitura de embalagens. Normalmente no recebimento de mercadorias importadas. Geralmente a mercadoria vem em três línguas. Sou apto no trabalho, até da para entender muita coisa, mas seria bom entender outras línguas.

EMPRESA 8 (E8)

Ramo: Construção Civil

Cargo do entrevistado: Almoxarifado (PE8)

1. Compra de materiais, notas, recebimento de cargas e estocagem.

2. Normalmente usamos a lingua com engenheiros e topógrafos terceirados do Peru, pessoalmente, por telefone ou por e-mail. Reuniões com empresas estrangeiras, algumas coisa dá para entender, porém uma maior eficiência é necessário ser fluente na língua. Alguns engenheiros falam inglês e espanhol, porém para os trabalhadores utilizam tradutores. Seria melhor que fosse de forma natural.

\section{EMPRESA 9 (E9)}

Ramo: Comércio Atacadista de Produtos Alimentícios

Cargo do entrevistado: Encarregado de Logística (PE9)

1. Faço de tudo... relatórios, notas, carga e descarga, pedidos.

2. Às vezes, usamos inglês ou espanhol. Conferência e recebimento de mercadorias, no pedido, às vezes. Tem que aprender a ler direito e entender os rótulos e especificação que nem nos produtos. Acho que é importante para todo mundo e para um profissional, então, mais ainda, pois te diferencia, abre oportunidades.

\section{EMPRESA 10 (E10)}

Ramo: Indústria e Comércio de plástico

Cargo do entrevistado: Conferente (PE10)

1. Recebo e confiro matérias primas em mercadorias

2. No meu cargo usamos o inglês para ler embalagens. Aprendi na prática não fiz curso e hoje leio as embalagens e sei dizer muita coisa. Seria bom ler e escrever tudo.

\section{EMPRESA 11 (E11)}

Ramo: Produtos Informáticos e Suporte Técnico

Cargo do entrevistado: Setor de compras (PE11)

1. Analiso o estoque e as vendas; faço reposição de produtos; preços e cotações de preços.

2. A diretoria e gestão usam o inglês para várias coisas, falar com fornecedores, por telefone, em reuniões, escrever e-mails. Hoje, é imprescindivel falar fluente a língua inglesa. Quando fui selecionando para trabalhar aqui, um dos requisitos era o inglês e eu havia feito cursos rápidos e sabia o básico, talvez isso também tenha me favorecido.

\section{EMPRESA 12 (E12)}

Ramo: Serviços de Telecomunicações

Cargo do entrevistado: Auxiliar de almoxarifado (PE12)

1. Fico responsável pela estocagem de matérias e distribuição 
2. Usamos mais o inglês. Somo uma empresa de comunicação e suporte, o inglês é muito usual. Às vezes, nas compras, falamos disso por e-mail, Skype e ou até mesmo pesquisando na internet. Então, acredito que saber uma língua é muito importante.

\section{EMPRESA 13 (E13) \\ Ramo: Atacadista Produto Alimentício \\ Cargo do entrevistado: Coordenador de Filial (PE13)}

1. Analiso o desempenho dos produtos quanto aos concorrentes, participação do mercado e outras coisas.

2. A partir do coordenador de Logística, tem que usar inglês. Em reuniões com promotores, utilizamos vários termos técnicos em inglês, então não é saber só um pouco de comunicação tem que saber falar alguns termos técnicos. Acho que é preciso ser fluente se possível, para falar ou escrever, pois trabalho em uma multinacional, da qual o presidente faz visitas constantes nas filiais e conversar com o presidente é uma grande diferencial.

\section{EMPRESA 14 (E14)}

Ramo: Hospitalar

\section{Cargo do entrevistado: Auxiliar de Logística (PE14)}

1. Realizo controle de entrada e saída de materiais. Faço solicitação de compras, recebimento e descarte de matérias.

2. $O$ inglês nas compras e gerenciamento. Precisamos falar e escrever para clientes e fornecedores (...). Sim, por e-mail, por telefone, pessoalmente. A boa comunicação é de grande importância na área de trabalho.

\section{EMPRESA 15 (E15) \\ Ramo: Metalúrgica \\ Cargo do entrevistado: Gerente de compra e venda (PE15)}

1. Confeccionamos e montamos ferramentas, tubos, chapas, perfil, telhas, fechaduras e etc. Importamos e exportamos matéria prima e mercadorias.

2. Como trabalhamos com matéria prima exportada e importada o inglês para o cargo de gerente de compra-venda é muito cotado (...). Sim várias atividades que fazemos no dia a dia pedem o uso do inglês, por exemplo, lemos e escrevemos e-mail, sites, relatórios, documentos (faturas, recibos, nota fiscal etc.) (...) Sim, fazemos viagens a trabalho, atendemos clientes por telefone, pessoalmente. Algumas vezes são necessárias sim reuniões com empresas estrangeiras. É importante ser fluente em alguma língua, principalmente o inglês. Tive que aprender e ser totalmente fluente, se alguns dos meus funcionários fossem fluentes, me ajudaria bastante. 


\section{UNIDAD 1 - Tema 1 \\ EMPRESA}

\section{Tópico 1: Idea de Negocio}

1. Antes de leer el texto, discute y reflexiona con tus compañeros/as:

a. ¿̇Qué es un emprendedor?

b. ¿̇Tienes algún tipo de negocio propio o ya has tenido? Cuéntanos tu experiencia.

Cómo son los emprendedores que se atreven a lanzarse en plena crisis

\section{El momento de los valientes}

Tenaz, persistente, austero y largoplacista. Quien se anima a montar un negocio en el momento actual está más cerca del estereotipo del corredor de fondo que del malabarista de otras épocas. Para estos emprendedores, la crisis lejos de ser una barrera se convierte en una gran ventaja. Pero también tienen sus pequeñas debilidades. Te explicamos lo que debes potenciar y lo que conviene evitar, si eres uno de ellos.

http://www.emprendedores.es/crear-una-empresa/tipos-de-emprendedores-en-tiempos-de-crisis

c. $\dot{\imath}$ Crees que sea posible emprender en tiempos de crisis? ¿Qué te parece la idea del texto?

"Emprender en tiempos de vacas flacas no es una mala opción. Más bien todo lo contrario. Sabido es que el simbolo chino para representar el concepto crisis se puede traducir a la vez como peligro $y$ como oportunidad y la barrera entre uno y otro significado está en la mente y la habilidad del empresario"

\section{DAR OPINIÓN}

(Yo) creo que... Para mí,... (A mí) me parece que... Desde mi punto de vista... Creo que... (Yo) pienso que... Según lo que he leído... En mi opinión... Desde mi punto de vista... A mi modo de ver... Según... (Yo) considero que... (Yo) opino que... (Yo) veo que... (Yo) diría que... (Yo) no creo / no pienso / no considero / no opino / no veo / no diría / (A mí) no me parece que + subj.

A mi entender / parecer... / A mi juicio.

En mi modesta / humilde opinión.

(A mí) me da la sensación / impresión de que... (Yo) soy de la opinión... (Yo) estimo

2. El texto habla de las nuevas tendencias que los emprendedores de la crisis suelen explotar. 
a. ¿¿Cuáles son, según el texto, las nuevas apuestas de mercado?

b. Investiga otras ideas o experiencias de éxito para emprender en tiempos de "vacas flacas" y compártelas con todo el grupo.

3. ¿Sabes que es el análisis Swot/FODA? Lee el texto y contesta a las preguntas que lo siguen.

\section{La matriz FODA 55}

La matriz FODA es una herramienta de análisis que puede ser aplicada a cualquier situación, individuo, producto, empresa, etc. Es como si se tomara una "radiografía" de una situación puntual de lo particular que se esté estudiando.

\begin{tabular}{|c|c|}
\hline POSITIVOS & NEGATIVOS \\
\hline \multicolumn{2}{|c|}{ FACTORES INTERNOS } \\
\hline $\begin{array}{l}\text { FORTALEZAS } \\
\text { Es decir aquellos puntos fuertes de nuestro } \\
\text { producto o servicio, nuestro personal, o de } \\
\text { nuestra empresa en general. } \\
\text { Ejemplo: amplio conocimiento y } \\
\text { experiencia en el sector, el tener el uso } \\
\text { exclusivo de una idea o producto, grandes } \\
\text { recursos financieros etc. }\end{array}$ & $\begin{array}{l}\text { DEBILIDADES } \\
\text { Los aspectos en los que la competencia nos } \\
\text { supera. } \\
\text { Ejemplo: Escasez de recursos, } \\
\text { desconocimiento del negocio, } \\
\text { Poca capacidad de acceso a créditos, etc. }\end{array}$ \\
\hline \multicolumn{2}{|c|}{ FACTORES EXTERNOS } \\
\hline $\begin{array}{l}\text { OPORTUNIDADES } \\
\text { Son los aspectos positivos que nos ofrece el } \\
\text { entorno, es decir todos los cambios } \\
\text { legislativos que contribuyan } \\
\text { favorablemente a aumentar } \\
\text { nuestras ventas o mejorar la producción } \\
\text { Ejemplo: necesidad del producto, nueva } \\
\text { tecnología, crecimiento de la economía, } \\
\text { convenios con otros países, etc. }\end{array}$ & $\begin{array}{l}\text { Todo aquello que puede suceder y que nos } \\
\text { afectaría negativamente. } \\
\text { Ejemplo: cambios legales, restricciones de } \\
\text { suministros, recesión de la economía, } \\
\text { competencia muy agresiva, etc. }\end{array}$ \\
\hline
\end{tabular}

a. ¿ Crees que el análisis FODA es una herramienta importante al crear una empresa?

b. Pensando en el entorno socioeconómico de la ciudad donde vives, ¿̇qué productos/servicios son posibles detectar como necesidades? ¿Qué tipo de empresa abrirías? Las necesidades pueden ser traducidas en oportunidades de negocio. Por eso, investiga las necesidades que tiene la gente a tu alrededor, entrevistando algunas personas (tus posibles clientes potenciales) y descubre lo que no hay o las deficiencias de un producto o servicio en tu entorno. Presenta el resultado al grupo.

- clientes/públicos potenciales:

- principal actividad/producto/servicio:

\footnotetext{
5555 http://www.matrizfoda.com/ (con adaptaciones)

Imagens livres https://pixabay.com http://www.shutterstock.com
} 
5. Para "abrir una empresa" es necesario elaborar el plan de negocio. Con tu grupo crea el plan de vuestra empresa y para ello ten en cuenta los siguientes criterios:

A. misión/objetivos de la empresa

B. análisis de mercado

- fortalezas, debilidades, oportunidades y amenazas

\section{Tópico 2: Organización de la empresa}

6. Además del análisis de mercado es necesario definir los sectores, la cantidad de persona que va a trabajar en la empresa y sus funciones. Para ello, prepara el organigrama de tu empresa.

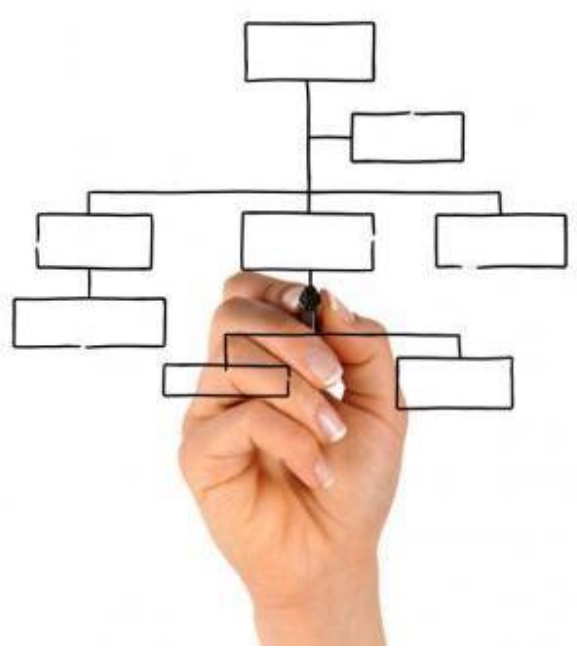

\section{¡Te toca! Tarea Final}

7. Presenta tu empresa y de tu grupo para los demás grupos. Toma nota de las informaciones presentadas.

A. Expositor - Presenta para el grupo la empresa

B. Oyentes - Pide informaciones sobre los datos presentados y completa la tabla a seguir. Lo que no consigues coger, hay que preguntarles.

\section{DATOS DE LA EMPRESA}

Nombre:

Tipo de empresa:

Número de teléfono:

Dirección:

Ciudad:

Código Postal:

Correo electrónico:

Página web:

Otros 


\section{ORGANIZACIÓN DE EMPRESA}

\section{A. Objetivos}

\section{B. Análisis de Mercado}

Fortaleza:

Debilidad:

Oportunidad:

Amenaza:

Principal actividad/producto/servicio:

Clientes potenciales:

\section{Organigrama}

Cargos y funciones:

\section{Identificar/ Dar información}

Nuestra empresa se llama...

Somos un empresa (líder) en el mercado de...

Nuestra empresa se dedica a.../

La actividad de la empresa es../Nos especializamos en...

Nuestra empresa está dirigida esencialmente/principalmente

a.../Nuestros servicios/productos son para...

Poseemos todo tipo de (servicio/producto) para...

Nuestro teléfono es el...

Su código postal es el...

Nuestra empresa se encuentra ubicada en.../Está situada

en... /Estamos en la (calle)...

Este/Esta es nuestro/o director/a...

general

comercial - de ventas y marketing

financiero

de administración

de recursos humanos

de producción

de distribución y transporte

...

\section{Estructuradores de la información}

\section{Ordenadores}

De inicio: primero, en primer lugar, por un lado, por una parte, para empezar, primeramente, lo primero es que... antes que nada, bien.

De continuidad: luego, después, en segundo / tercer lugar, por otro lado, por otra parte, por su parte, de otra parte, de otro lado, de igual forma / manera / modo...

De cierre: por último, en conclusión, para terminar, finalmente, para finalizar, en suma, bueno. a modo de conclusión, podríamos afirmar que...

Comentadores: Dues... Dues bien. así las cosas.
Pedir información

Persona:

¿Cómo se llama?

¿Quién es?

\section{Cantidad}

¿Cuántos/a...?

\section{Cosa}

¿Qué / Cuál...?

¿Cuál es el/la...?

\section{Actividad}

¿Qué hace?

¿A qué se dedica?

Lugar

¿Dónde?

\section{Pedir confirmación}

¿Puedes / Podrías decirme si...?

Quería saber si...

¿Puedes /Podrías confirmar (me)...? 


\section{UNIDAD 2 - TEMA 2 \\ EL PROFESIONAL}

\section{Tópico 1: El perfil}

1. Lee el texto, reflexiona y habla con tus compañeros:

\section{Cuatro países del sur soportan la mayor carga del desempleo regional: España, Grecia, Italia y Francia}

http://economia.elpais.com/economia/2014/04/15/actualidad/1397553478 293474.html http://www.elcaptor.com/2014/04/economia-europea-paro-latinoamerica.html

a. ¿Qué el texto intenta mostrar?

b. En tu opinión, ¿̇cuáles son las principales causas del paro?

c. En Brasil, ¿qué sector productivo crees que ha tenido más influencia en el desempleo? Construcción, agricultura, servicios, industria, comercio...

2. Lee el texto y opina con tus compañeros:

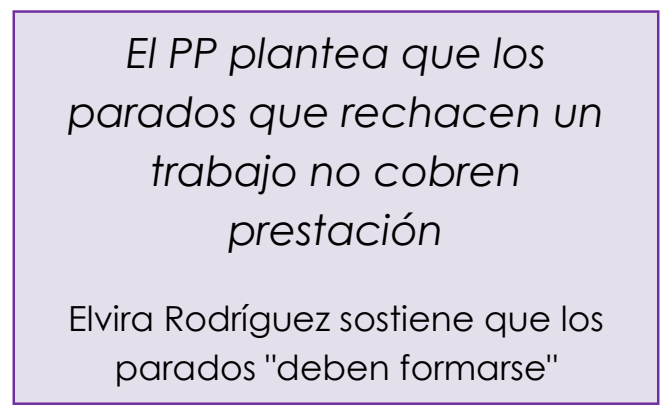

\section{Si a los parados se les ofrece un puesto, lo tienen que coger o sino, perderán la prestación}

\section{Elvira Rodríguez}

http://economia.elpais.com/economia/2012/07/05/actualidad/1341484415 610237.html

a. ¿QQué te parece la medida de la presidenta (Elvira Rodríguez) de la comisión de economía del congreso de España?

\begin{tabular}{l} 
Valorar \\
(Muy / Bastante) bien/mal/regular \\
Así, así \\
Es (muy / bastante / un poco) + adj. \\
Esto está (muy / bastante) bien / mal / \\
Es demasiado / muy + adj. \\
No es nada + adj. (fácil...) \\
!Qué + adj.! ¡Qué bien / mal \\
¡Estupendo! / ¡Perfecto! \\
Es / Me parece de buen / mal / pésimo gusto. \\
Es / Me parece + adj. / SN + lo que... \\
Resulta + adj. / SN. \\
Me parece de perlas / de cine / de miedo / de pena que... \\
\hline
\end{tabular}




\section{b. Lee la opinión de algunas personas sobre esta medida. ¿Estás de acuerdo?}

Ah! Sería mejor que esta señora matizara la declaración, porque sino estará avalando, por ejemplo, que si ofrecen un trabajo mal pagado a $80 \mathrm{~km}$ de la casa de uno, que necesite gastar en transporte público o en gasolina más de lo previsto y no llegue a tiempo a recoger a sus hijos del colegio... Da igual!! de las gracias y béseles las manos por su gran generosidad...

$07 / 07 / 2012$, a las $14: 22$

Pues me parece bien, siempre que el trabajo sea digno y adecuado a la formación del demandante. Más control a los que cobran el paro mientras trabajan sin estar dados de alta; ni pagan sus impuestos y además se llevan parte de lo que nos quitan al trabajador legalmente contratado.

$\mathrm{Si}$, pero sus intenciones no van por ahi. Ellos lo que quieren es que el parado pierda su prestación si no aceptan la primera mierda que les ofrezcan, por ej, que esté cobrando $800 €$ de paro y les ofrezcan un trabajo por 500 .

$06 / 07 / 2012$, a las $16: 51$

Pues a mi no me parece mal, siempre y cuando sea en puesto de trabajo similar y salario similar. Es decir condiciones similares al anterior puesto de trabajo. Pero da igual puesto que lo que no hay es trabajo que es lo que tienen que fomentar.

No creo que el problema del paro sea gente "poco Formada" todo lo contrario, se quitan títulos de sus currículums para que los empresarios los seleccionen, esto es más una medida par ganar tiempo, si los llaman para 3 dias de camarero no los sacan de pobre pero tendrá que volver a pedir papeles, cita al INEM y vuelta a empezar un mes mas para cobrar ... ¿y esos famosos cursos se harán a través de sindicatos y demás entidades?? supongo y que por un curso "barato" cobrarán una pasta y eso no es ahorrar, eso es un despropósito para mantener callados a los sindicatos con los recortes.

\section{Expresar acuerdo/desacuerdo}

(No/Sí) estoy de acuerdo. Esto es muy...

(Esto) está (muy) bien / mal. Esto no está bien.

(No/Sí) estoy de acuerdo.

Yo, también / tampoco

Sí, es verdad.

Sí, para mí también / tampoco + repetición de la opinión / valoración

Sí, yo también creo que (no)...

Yo (no) pienso como tú...

Sí, a mí también / tampoco me parece que...

Sí, yo también / tampoco creo que / pienso que...

Sí, es verdad / cierto que

Es evidente que... / No es evidente que...

Está claro que...

(Yo) comparto tu opinión / tu punto de vista

Pienso de la misma forma / lo mismo que tú

(no) Estoy de acuerdo con / en...

Claro que no / Claro que sí

Estoy de acuerdo contigo, pero...

No estoy de acuerdo

Tienes razón, pero / aunque / sin embargo... 
b. En tu opinión, ¿̇es importante una persona tener una formación profesional? ¿ Qué crees que es importante tener hoy un profesional para conseguir un buen trabajo? 2. En la película "El método", aspirantes a un puesto de trabajo tienen que hacer lo posible para ir eliminando candidatos. Se trata de que cada uno haga prevalecer sus talentos y demuestre que él es el más adecuado para el puesto. Mira la película y discute con tus compañeros estas preguntas que te proponemos a continuación:

a. ¿̇ué te ha parecido el método Grönholm para la selección de candidatos?

b. El proceso de selección (en la película) intenta sacar lo mejor y lo peor de cada uno de los aspirantes como profesionales y como personas. ¿Qué piensas sobre las actitudes de los personajes?

c. ¿ Crees que los personajes fueron éticos o intentaran pisotear a los demás con tal de llegar a lo más alto? ¿ ¿Qué valores humanos han dejado atrás por este puesto de trabajo?

d. Contesta a la pregunta planteada al final del tráiler ¿̇Hasta dónde llegarías para ser el elegido? Piensa sobre el asunto.

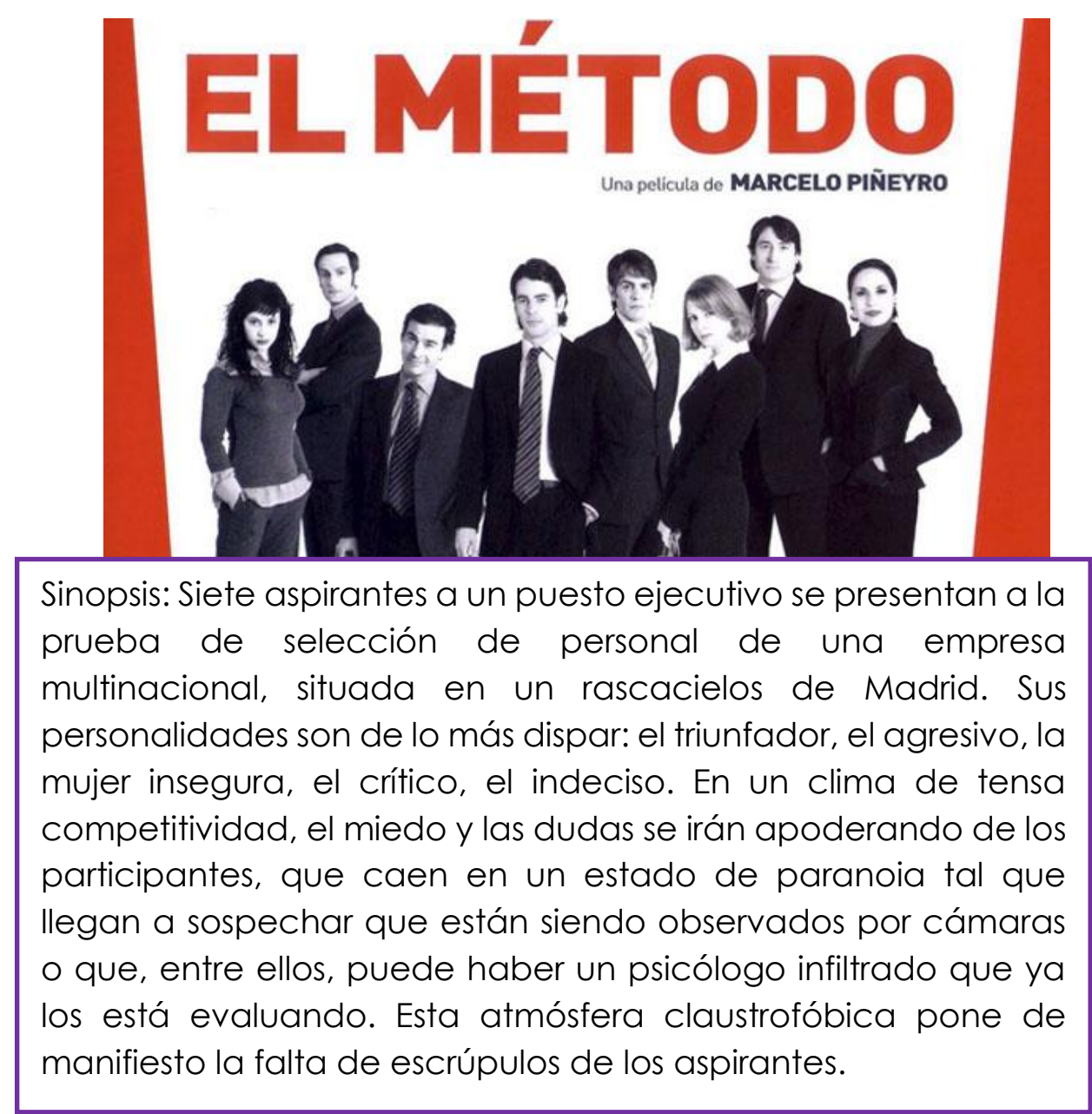

https://www.youtube.com/watch?v=fGExlIMfWyc.

3. Conoce mejor a ti mismo, a tus compañeros y deja que te conozcan mejor como profesional. Describe tus aspectos personales positivos y/o negativos, tus puntos fuertes y/o débiles profesionalmente y apunta las características que crees que son positivas y fuertes de tus compañeros. 
4. Cada grupo va a crear una lista con las características positivas de los compañeros de clase como profesionales y en entre todos van a construir el "decálogo del buen profesional".

\section{Tópico 2: Recursos Humanos}

5. Define el perfil y las tareas del profesional que tú y tu grupo desean contratar y prepara un anuncio de trabajo con estas especificaciones.

6. Estudia los anuncios preparados por los demás grupos en el "mural de anuncios de trabajo" y prepara con tu grupo un currículo para un puesto de trabajo específico (planteado por los demás).

\section{¡Te toca! - Tarea Final}

7. En grupo participa de una entrevista de trabajo formulando y respondiendo preguntas sobre los currículos. 


\section{Unidad 3 - Tema 3 \\ Mercados}

\section{Tópico 1: Productos y Servicios}

1. Reflexiona y discute con tus compañeros:

a. $\dot{\imath}$ Compras realmente solo lo que vas a necesitar?

b. ¿¿Qué hay detrás de tus vaqueros? ¿¿Quiénes y cómo lo realizaron? ¿̇En qué condiciones humanas y laborales? ¿Cuántos intermediarios hubo hasta que llegó a tus manos? ¿ Cuánto te va a durar?

c. ¿̇Conoces a este sello? ¿̇Sabes qué significa?

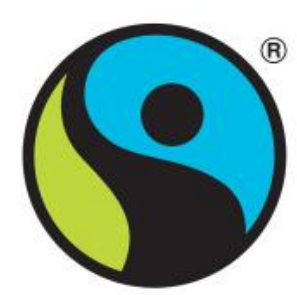

2. En los años 80 comenzó a desarrollarse el comercio justo en los pequeños comercios y tiendas concienciadas. En tu opinión, żcuáles son los objetivos o características del comercio justo? Marca las opciones.

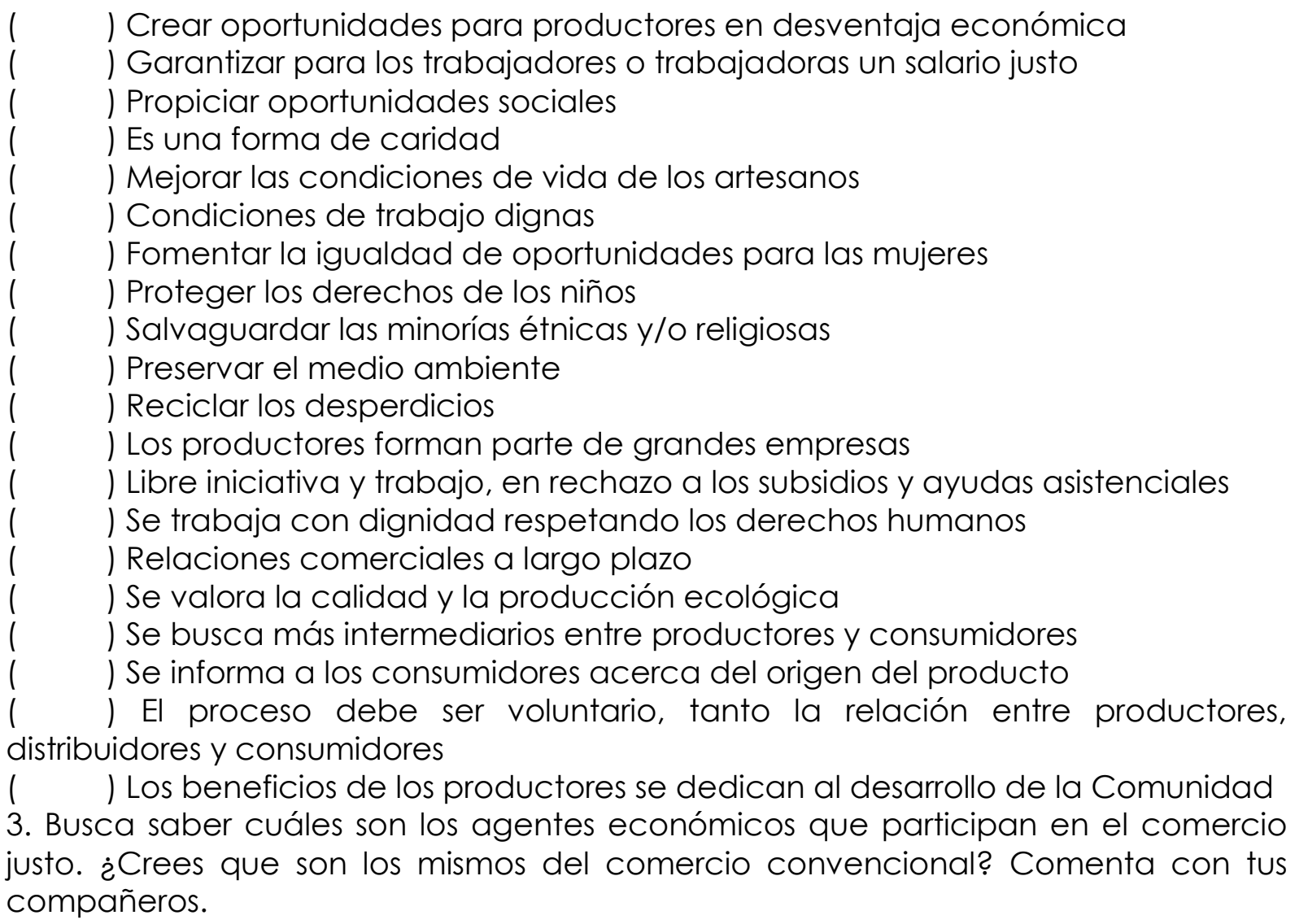




\begin{tabular}{|crrr|}
\hline $\begin{array}{c}\text { Productor } \\
\text { Corredor de bolsa }\end{array}$ & Tiendas de comercio & Mayorista \\
Cafeterías & Distribuidor & Comercio ecológico \\
Artesanos & Comunidades & Organizaciones voluntarias \\
\hline
\end{tabular}

4. Mira el video "el comercio junto justo en 6 pasos" (https://www.youtube.com/watch? $v=U 2 \mathrm{~J} \| r$ rspnA) y comenta con tus compañeros:

a. ¿Qué te parece el comercio justo?

b. ¿̇Estás de acuerdo con él?

c. ¿ Cuáles crees que son los productos más habituales del comercio justo?

d. ¿̇Crees que el objetivo del comercio justo hoy día es lo mismo de sus años iniciales?

5. Los productos del comercio justo están en todas partes incluyendo las grandes cadenas de hipermercados. Mira el documental "comercio justo a cualquier precio" (https://www.youtube.com/watch? $\mathrm{v}=0 \mathrm{c} 220 \mathrm{n} 1 \mathrm{kvC0}$ ) y marca las opciones semejantes con las que opinas:

( ) La venta de estos productos beneficia a los productores en desventaja económica, para quienes se supone que van los beneficios obtenidos

( ) El precio que se paga a los productores permite condiciones de vida dignas

( ) Los productores de los países en desarrollo enfrentan problemas cuando sus productos "justos" empiezan a tener éxito en el mundo desarrollado

( ) Los gigantes de la distribución alimentaria utilizan la marca "comercio justo" para diferenciar productos tradicionales y, sobre todo, a los compradores que están dispuestos a pagar más por ellos

( ) Es posible que el comercio justo pase a competir con los productos de marca blanca

( ) Los productores del comercio justo hay que negociar con los distribuidores

) Los productores del comercio justo hay que competir en el libre mercado

) Puede ser que cuando surge la posibilidad de los productores de comercio justo convertirse en un productor exitoso a escala mundial se agua la fiesta, porque la posibilidad de obtener mayores beneficios mediante una producción a mayor escala infringe su "filosofía" empresarial

Ahora pon en común tus opiniones con las de tus compañeros y saca las conclusiones oportunas.

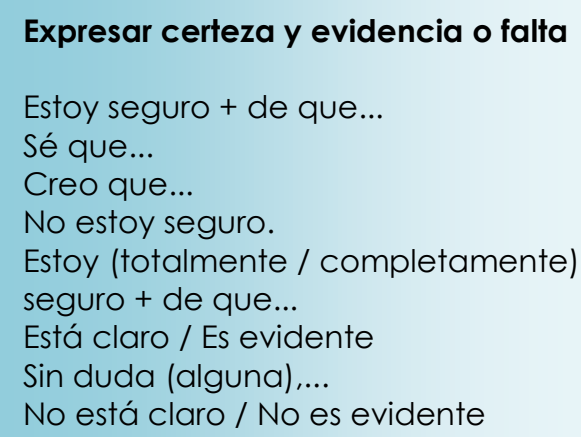

\section{Expresar posibilidad}

Quizá(s)...

Es posible/Es probable/Puede ser 


\section{Tópico 2: El plan de marketing}

6. Defina el principal producto y/o servicio que vas a ofrecer en tu empresa y describe sus características:

a) El producto y/o servicio propiamente dicho:

b) Aspectos innovadores y su diferencial:

c) El precio y la promoción de ventas (productos rebajados, descuentos, 2x1, tarjetas de fidelización, regalos, etc.)

\section{¡Te toca! - Tarea Final}

7. Prepara con tu grupo un folleto publicitario de vuestra empresa. Pon en el folleto todas las informaciones que crees que son importantes: principales productos $\mathrm{y} / \mathrm{o}$ servicios, qué precios tienen, etc. Preséntalo al grupo.

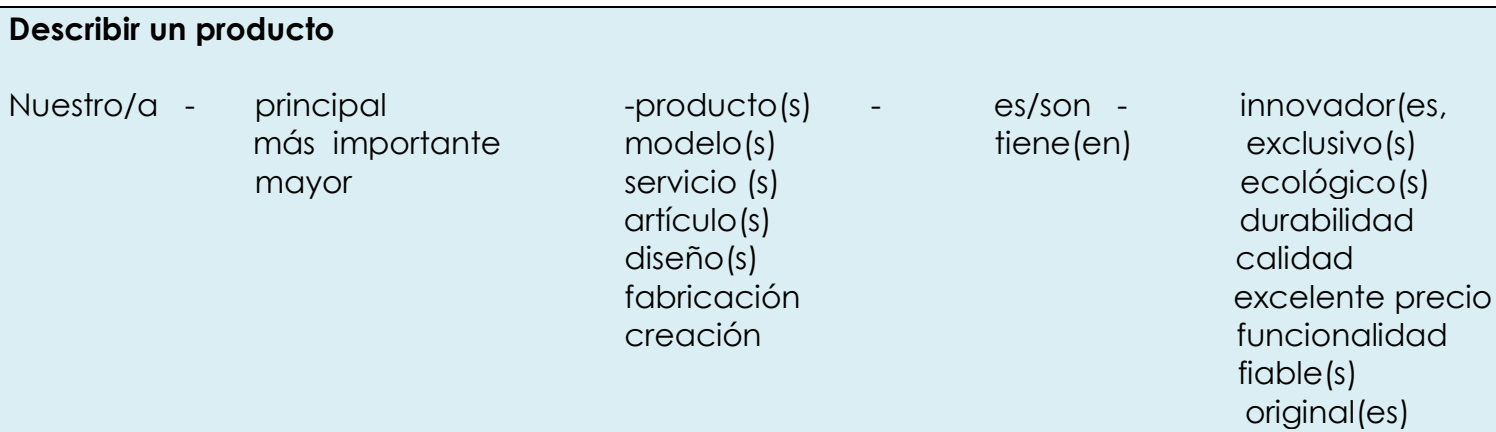




\section{Unidad 4 - Tema 4 \\ Comunicación}

\section{Tópico 1: Clientes y proveedores}

1. Reflexiona y charla con tus compañeros:

a. ¿Qué sabes acerca de la forma de comercializar y negociar en otros países?

b. En tu país, ¿existe algún protocolo de atención al cliente? ¿ Qué te parecen estos a seguir? (www.protocolo.org/laboral)

\section{Los clientes. Atencion, amabilidad y cortesía.}

Siempre que tratemos con clientes (por desagradables o pesados que sean) debemos hacerlo con toda amabilidad y corrección.

\section{Los proveedores. Negociación, equilibrio y respeto. Comportarse en todo momento.}

Tratamos siempre de conseguir una buena compra para nuestra empresa, en las mejores condiciones posibles.

\section{Negocios y protocolo.}

Un gesto tan simple como entregar o recibir una tarjeta de visita puede cerrarnos muchas puertas si no lo hacemos bien.

c. ¿̇Qué piensas sobre dejar la propina? ¿̇Y regatear?

2. Mira el vídeo "¡Quítate la vergüenza y aprende a regatear! Te hará ahorrar mucho dinero" (http://dinero.univision.com/prosperidad/ahorro/tus-cuentas/article/201307-11/tacticas-ahorrar-dinero-regateando-compras) y enseguida comenta con tus compañeros:

a. ¿̇Es recomendable regatear? ¿Cuándo? ¿̇Te parece bien?

3. En tu opinión, ¿̇qué actitudes son importantes a la hora de comprar y regatear? Lista con tus compañeros posturas que un vendedor debe tener. 
4. Vas a participar de una feria de exposición. Diseña tu tarjeta de visita, con tus datos personales y profesionales e inicien conversaciones con los demás participantes en la feria, comercializa tus productos. Los clientes van a coger y apuntar datos sobre tu empresa y sus productos, y se posible regatear precios.

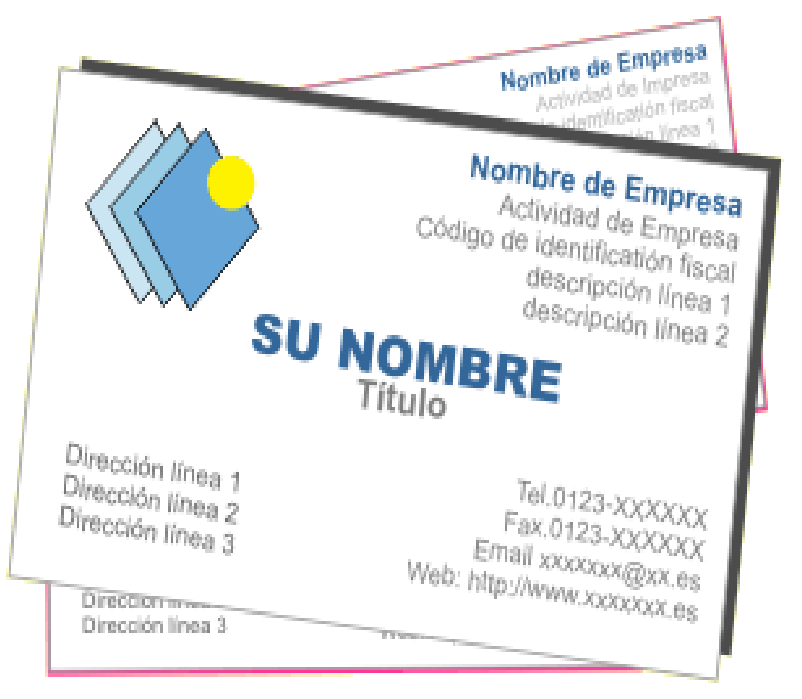

Preguntar el precio y regatear

¿Cuánto es/son...?

¿Cuánto vale $(n)$...?

¿Cuánto cuesta(n)...?

¿A cuánto está(n)...?

¿Cuál es el precio de ...?

Es demasiado/Es muy caro/Es carísimo/Es una ganga

¿Cuál es el mejor precio que me puedes

hacer?

¿Cuánto es lo mínimo?

¿En cuánto me lo dejas?

¿Se puede bajar un poco el precio?

Se puede hacer un descuento de $5 \%$

Te/Le dejo/puedo dejar en ...

¿Cómo va a pagar?

\section{Tópico 2: Documentos, Logística y transporte}

5. Tras analizar el catálogo de las empresas que han participado de la feria, escribe un correo electrónico a una de ellas y prepara una orden de compra solicitando (2) productos que interesan a tu empresa. Utiliza algunas de las informaciones a seguir y/o busca otras.

a. Encabezamiento - Muy señor(es) mío(s) / Estimado señor...

b. Referencia a contactos previos con el proveedor - Muchas gracias por el envío de su catálogo/ lista de precios..

c. Hacer el pedido - Por favor, envíeme los siguientes artículos de su catálogo...

d. Forma de pago - Como acordamos el pago será por cheque bancario / transferencia bancaria..

e. Hablando de fechas - Les ruego

que envíen el pedido dentro del plazo estimado...

f. Medio de envío - Que el envío se haga por carretera / por ferrocarril / por vía aérea / por vía marítima...

g. Despedida - Atentamente (le saluda/se despide) / Cordialmente...

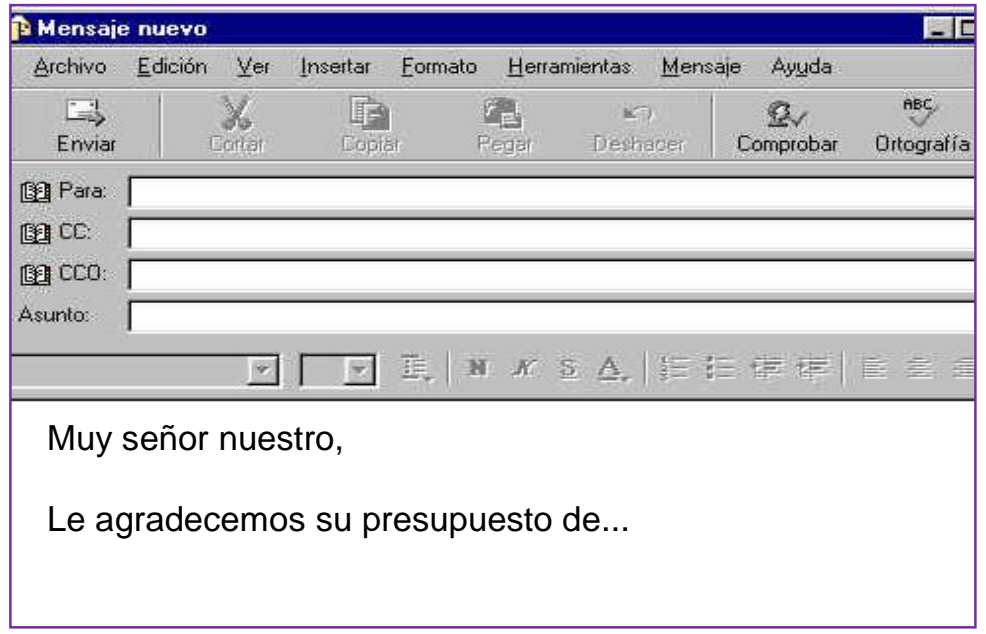




\begin{tabular}{|l|l|}
\hline Nombre de la empresa: & Orden de Compra $\mathrm{n}^{\circ}$ \\
\hline Dirección: & \\
\hline
\end{tabular}

\begin{tabular}{|l|l|}
\hline Proveedor: & \\
\hline Dirección: & Código Postal: \\
\hline Ciudad: & Teléfono: \\
\hline C.U.I.T56: & País: \\
\hline Condiciones de pago: & \\
\hline
\end{tabular}

\begin{tabular}{|l|l|l|}
\hline $\begin{array}{l}\text { FECHA DEL } \\
\text { PEDIDO }\end{array}$ & SOLICITANTE & MEDIO DE ENVÍO \\
\hline & & \\
\hline
\end{tabular}

\begin{tabular}{|c|c|c|c|}
\hline CANTIDAD & DESCRIPCIÓN & $\begin{array}{l}\text { PRECIO POR } \\
\text { UNIDAD }\end{array}$ & TOTAL \\
\hline & & & \\
\hline & TOTAL NETO & & \\
\hline & IMPUESTO SOBRE VENTAS & & \\
\hline & ENVÍO & & \\
\hline & TOTAL GENERAL & & \\
\hline
\end{tabular}

\section{¡Te toca! - Tarea Final}

6. Simula en grupo una situación de compra-venta entre un Comprador/Cliente e Proveedor/Vendedor

Confirma datos de los productos seleccionados por teléfono. Informa/Pregunta sobre plazos, fechas, condiciones de entrega, precio, cantidad del productos etc. 